\title{
Electronic Effects on Narcissistic Self-Sorting in Multicomponent Self- Assembly of Fe-Iminopyridine Meso-helicates
}

Calvin A. Wiley, Lauren R. Holloway, Tabitha F. Miller, Yana Lyon, Ryan. R. Julian and Richard J. Hooley*

Department of Chemistry, University of California, Riverside, CA 92521.

richard.hooley@ucr.edu

Supporting Information

\section{Table of Contents}

1. Characterization of New Complexes

2. Kinetic Formation Experiments

2a. Summary of Kinetic Formation Experiments

$S-12$

2b. Standardized 2 Hour Kinetic Formation Experiments

2c. Standardized 1 Hour Kinetic Formation Experiments

3. Ligand Self-Sorting Experiments

3a. Fully Equilibrated Ligand Self-Sorting NMR Experiments

3b. Standardized $2 \mathrm{~h}$ Ligand Self-Sorting Experiments

4. Aldehyde Terminus Mixing Experiments

4a. Aldehyde Terminus Mixing Experiments with Suberone Ligand A

4b. Aldehyde Terminus Mixing Experiments with Suberol Ligand B

4c. Aldehyde Terminus Mixing Experiments with Suberenone Ligand $\mathbf{C}$ $S-57$

5. Aldehyde Displacement Experiments $S-66$ 


\section{Characterization of New Complexes}
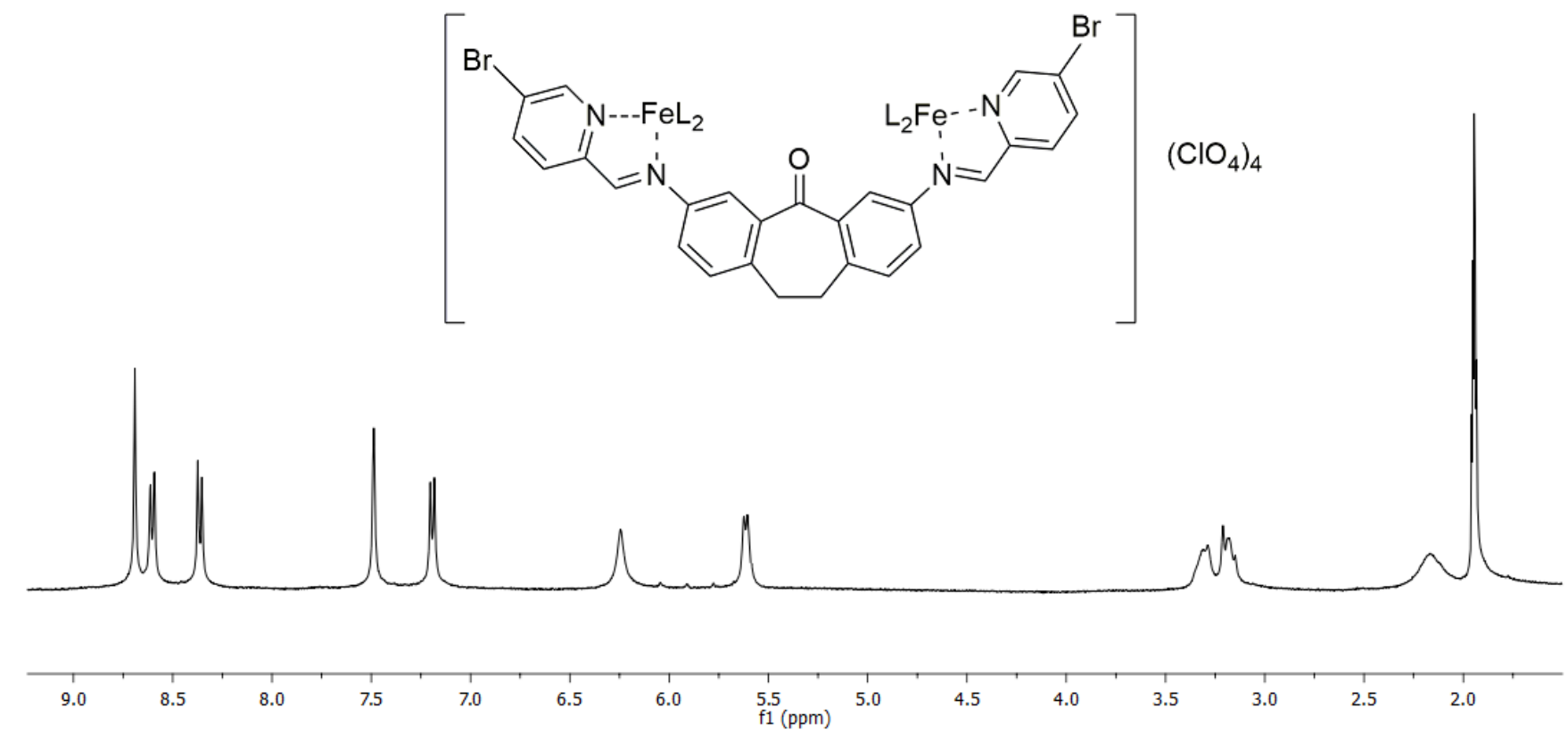

Figure S1. ${ }^{1} \mathrm{H}$ NMR spectrum of bromo-suberone meso-helicate $\mathbf{1} \cdot \mathrm{Br}_{6}\left(\mathrm{CD}_{3} \mathrm{CN}, 500 \mathrm{MHz}, 298 \mathrm{~K}\right)$.

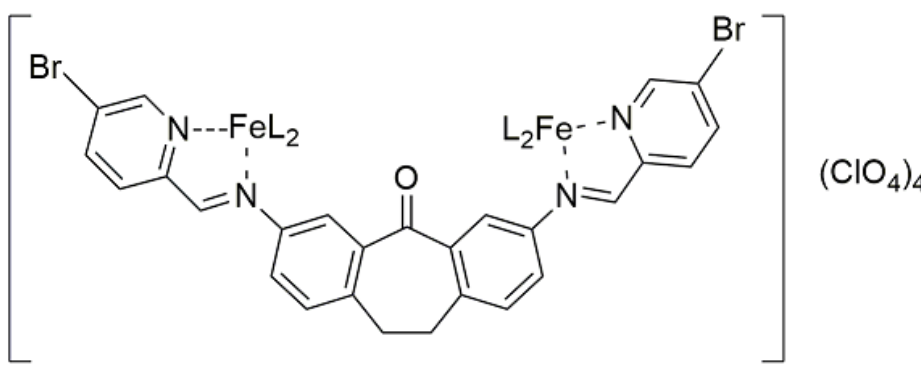
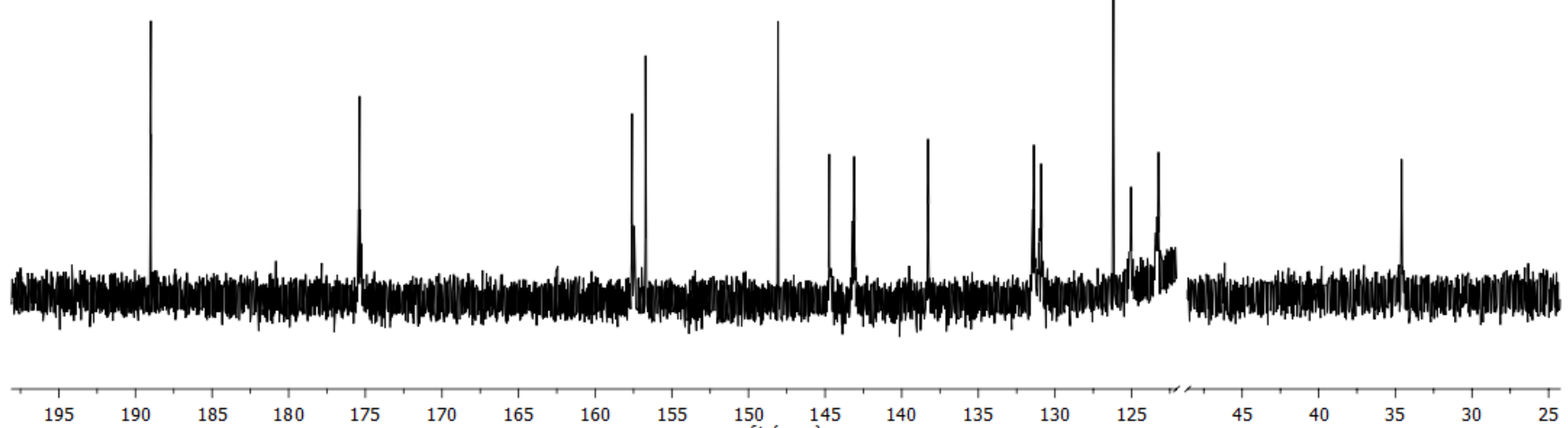

Figure S2. ${ }^{13} \mathrm{C}$ NMR spectrum of bromo-suberone meso-helicate $\mathbf{1} \cdot \mathrm{Br}_{6}\left(\mathrm{CD}_{3} \mathrm{CN}, 125 \mathrm{MHz}, 298 \mathrm{~K}\right)$. 


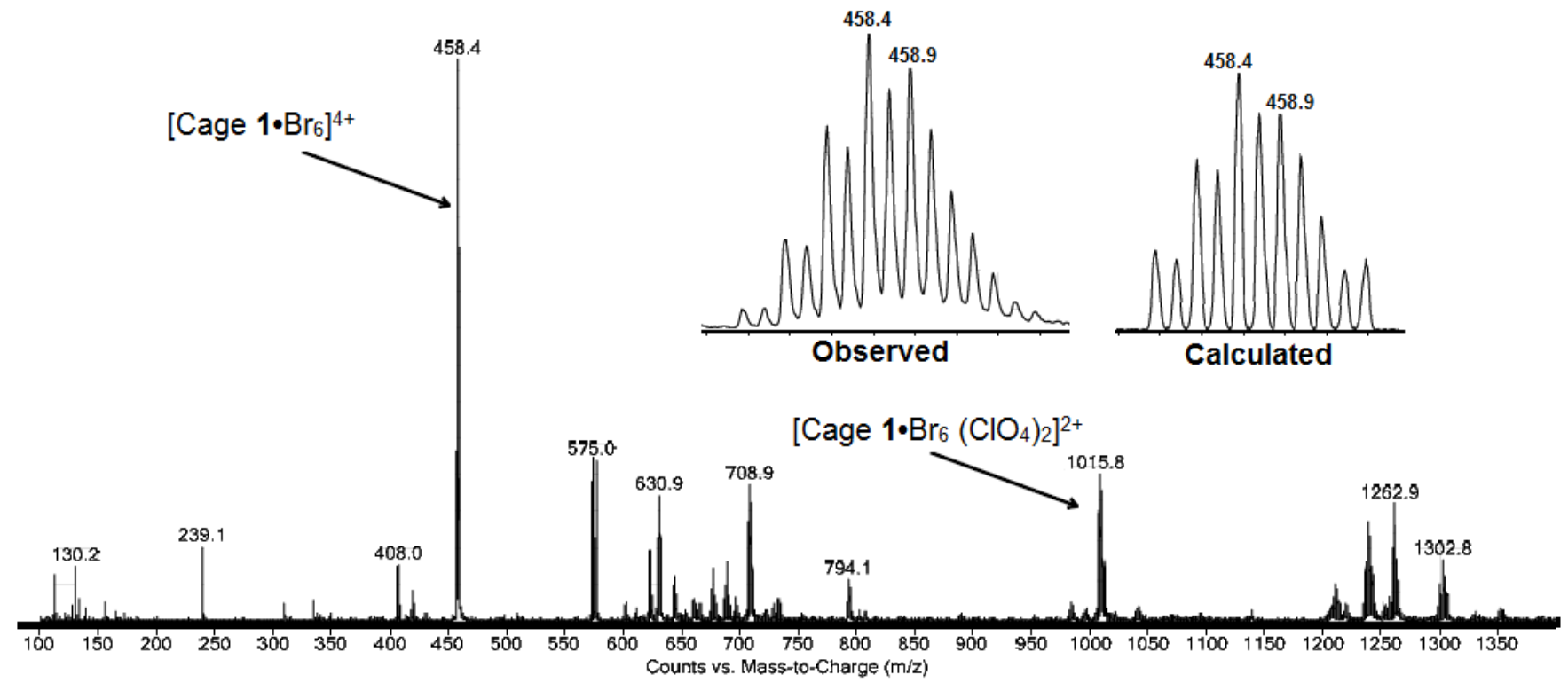

Figure S3. ESI-MS of bromo-suberone meso-helicate $1 \cdot \mathrm{Br}_{6}\left(\mathrm{CH}_{3} \mathrm{CN}\right)$.

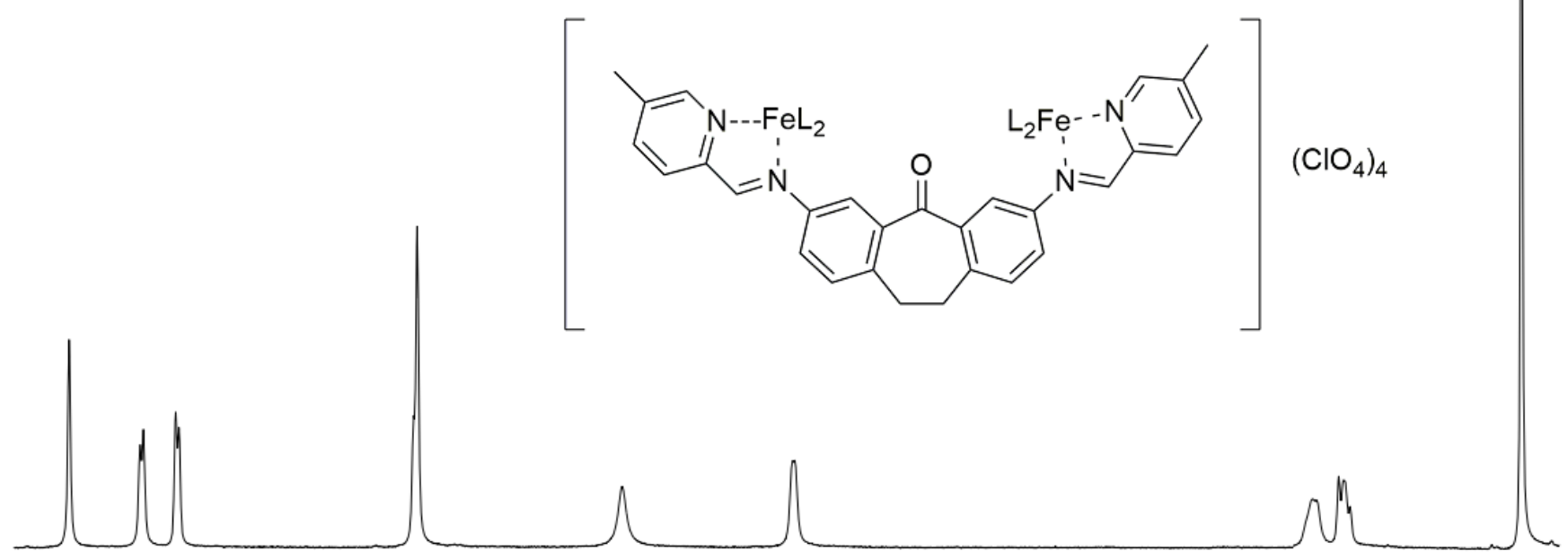

$\begin{array}{llllllllllllllllllllllllllllllllllllllllllll}8.8 & 8.6 & 8.4 & 8.2 & 8.0 & 7.8 & 7.6 & 7.4 & 7.2 & 7.0 & 6.8 & 6.6 & 6.4 & 6.2 & 6.0 & 5.8 & 5.6 & 5.4 & 5.2 & 5.0 & 4.8 & 4.6 & 4.4 & 4.2 & 4.0 & 3.8 & 3.6 & 3.4 & 3.2 & 3.0 & 2.8 & 2.6 & 2.4\end{array}$

Figure S4. ${ }^{1} \mathrm{H} \mathrm{NMR}$ spectrum of methyl-suberone meso-helicate $\mathbf{1} \cdot \mathrm{Me}_{6}\left(\mathrm{CD}_{3} \mathrm{CN}, 500 \mathrm{MHz}, 298 \mathrm{~K}\right)$. 


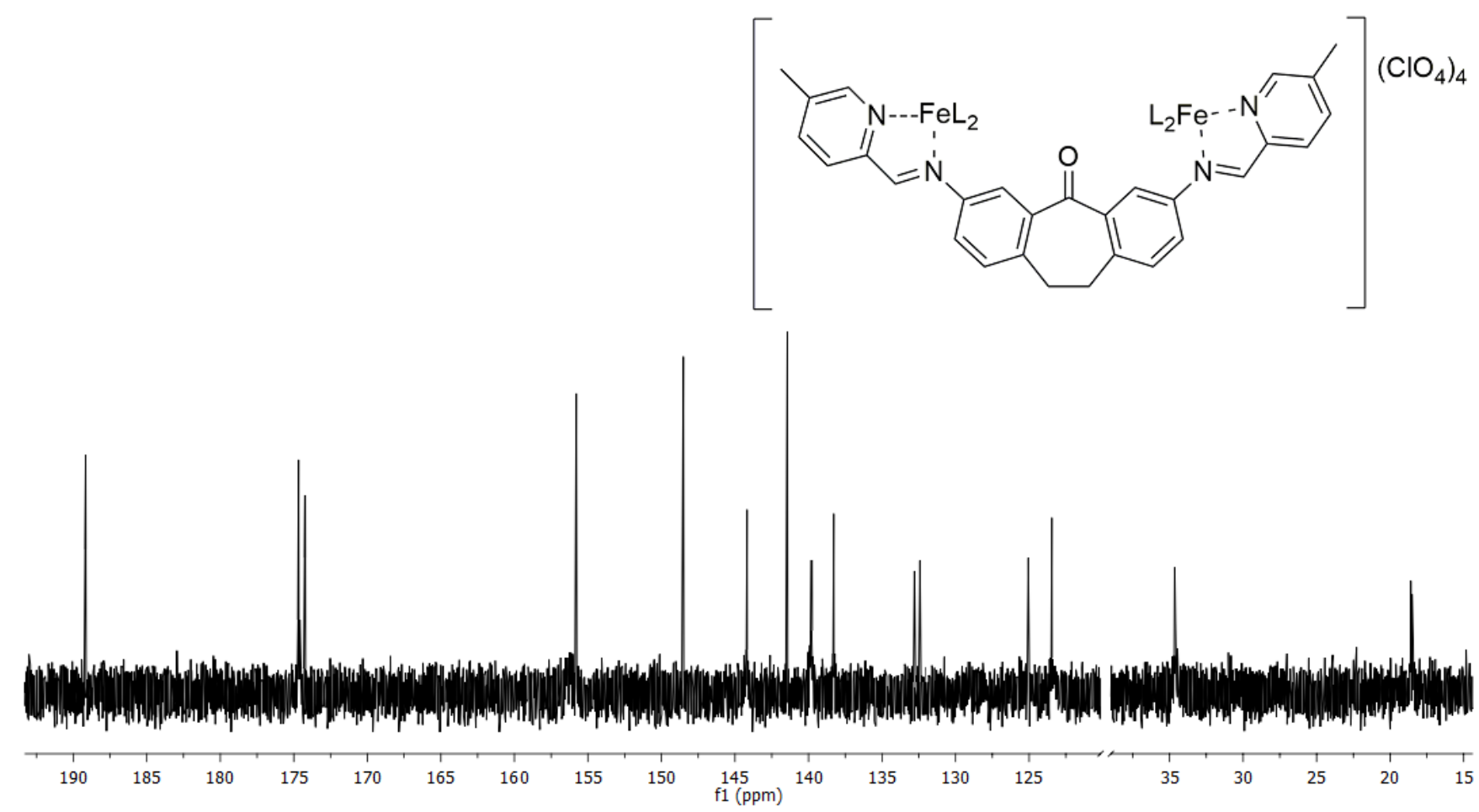

Figure S5. ${ }^{13} \mathrm{C}$ NMR spectrum of methyl-suberone meso-helicate $1 \cdot \mathrm{Me}_{6}\left(\mathrm{CD}_{3} \mathrm{CN}, 125 \mathrm{MHz}, 298 \mathrm{~K}\right)$.
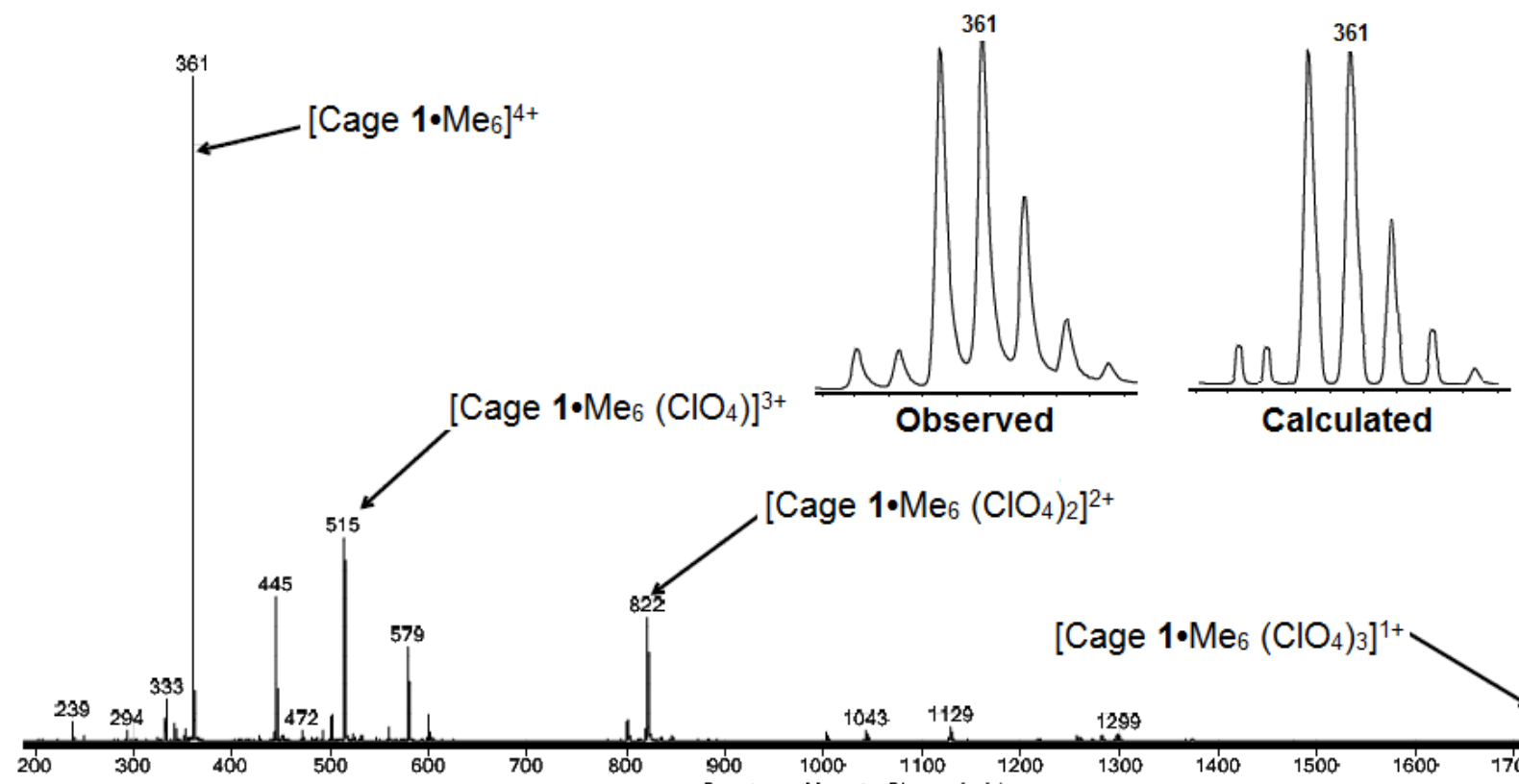

Figure S6. ESI-MS of methyl-suberone meso-helicate $\left[\text { Cage } 1 \cdot \mathrm{Me}_{6}\left(\mathrm{ClO}_{4}\right)_{2}\right]^{2+}\left(\mathrm{CH}_{3} \mathrm{CN}\right)$. 

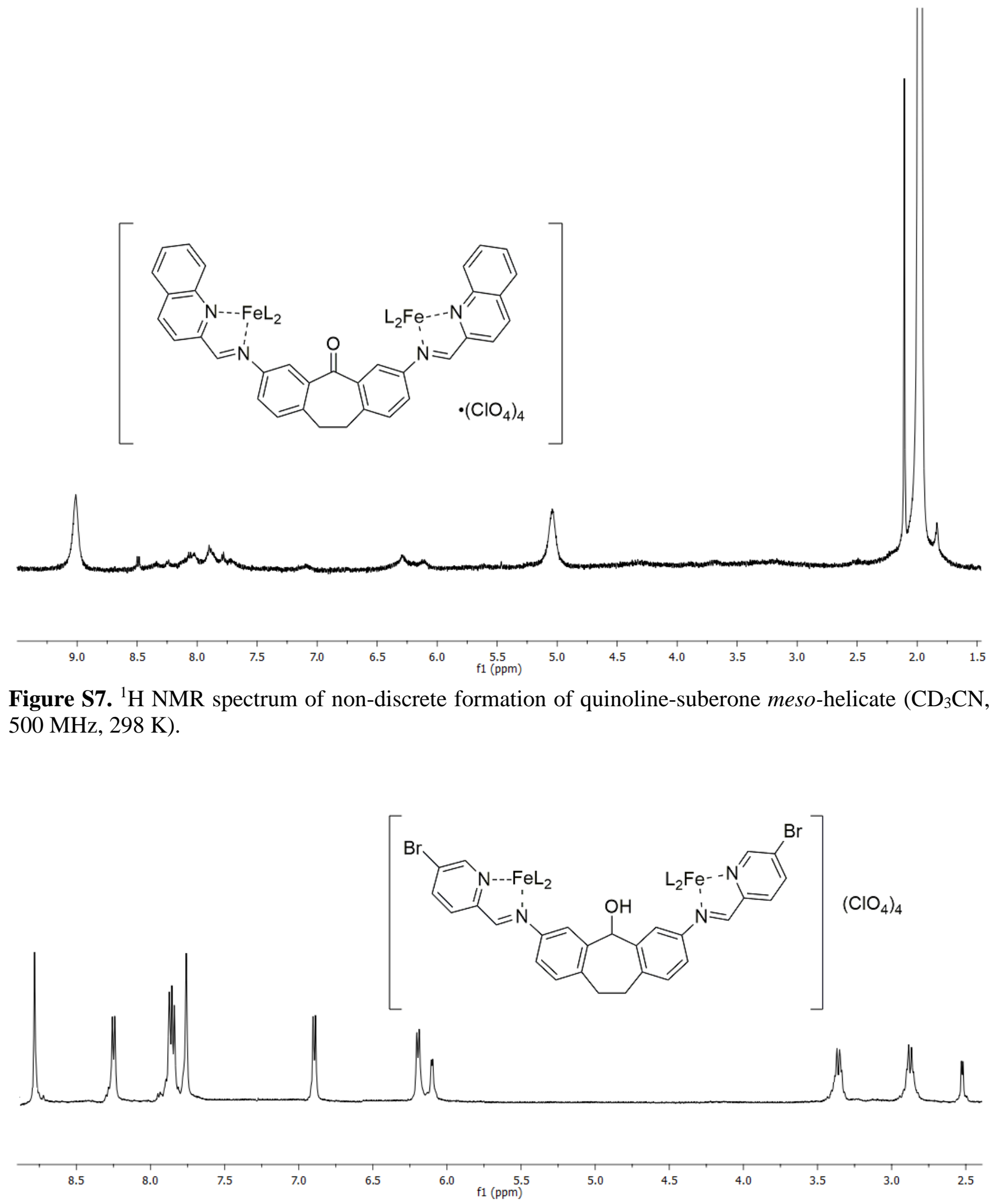

Figure S7. ${ }^{1} \mathrm{H}$ NMR spectrum of non-discrete formation of quinoline-suberone meso-helicate $\left(\mathrm{CD}_{3} \mathrm{CN}\right.$, $500 \mathrm{MHz}, 298 \mathrm{~K})$.

Figure S8. ${ }^{1} \mathrm{H}$ NMR spectrum of bromo-suberol meso-helicate $\mathbf{2} \cdot \mathrm{Br}_{6}\left(\mathrm{CD}_{3} \mathrm{CN}, 500 \mathrm{MHz}, 298 \mathrm{~K}\right)$. 


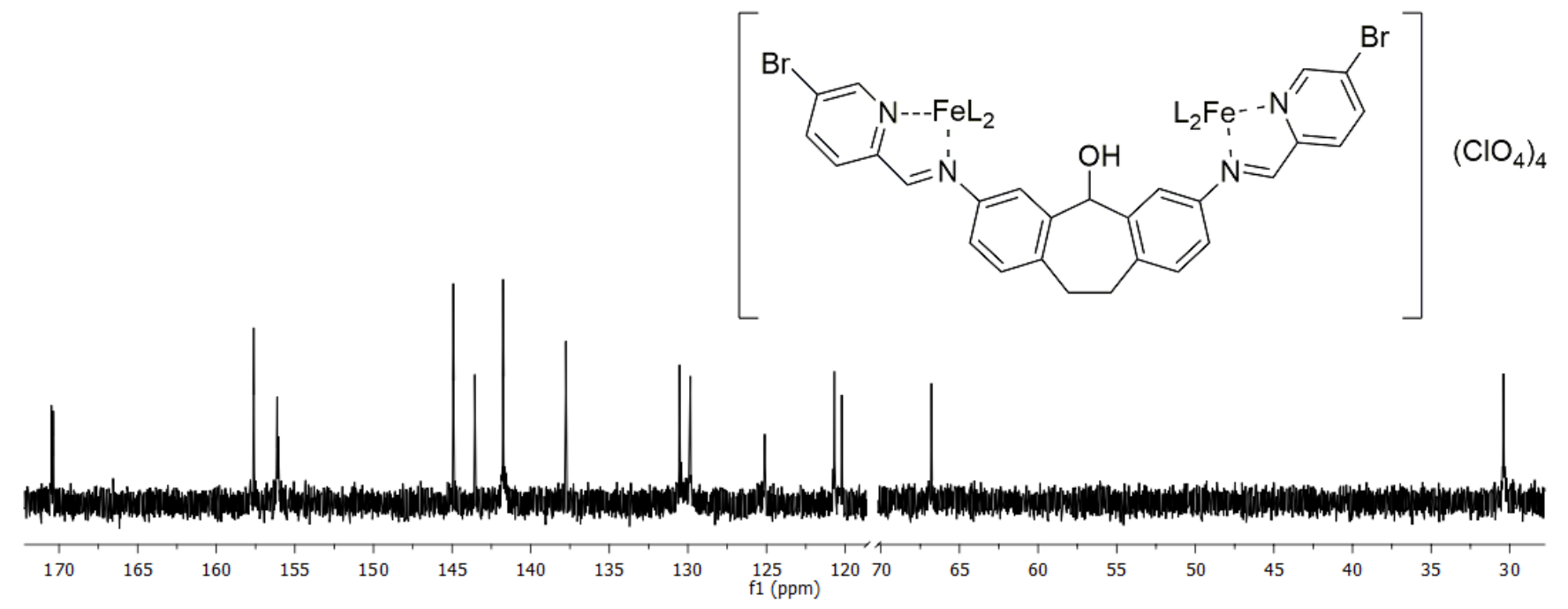

Figure S9. ${ }^{13} \mathrm{C}$ NMR spectrum of bromo-suberol meso-helicate $2 \cdot \mathrm{Br}_{6}\left(\mathrm{CD}_{3} \mathrm{CN}, 125 \mathrm{MHz}, 298 \mathrm{~K}\right)$.

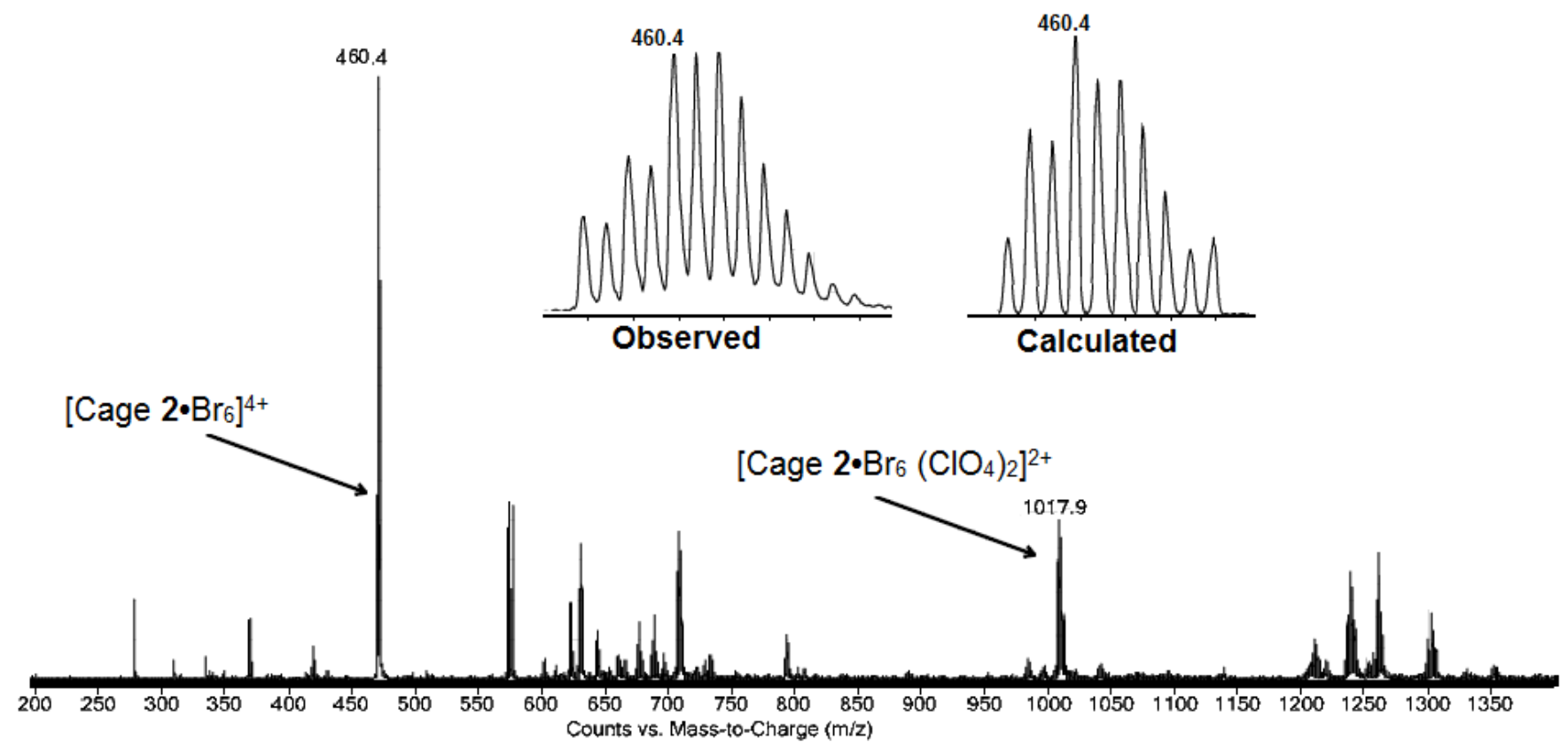

Figure S10. ESI-MS of bromo-suberol meso-helicate $2 \cdot \mathrm{Br}_{6}\left(\mathrm{CH}_{3} \mathrm{CN}\right)$. 


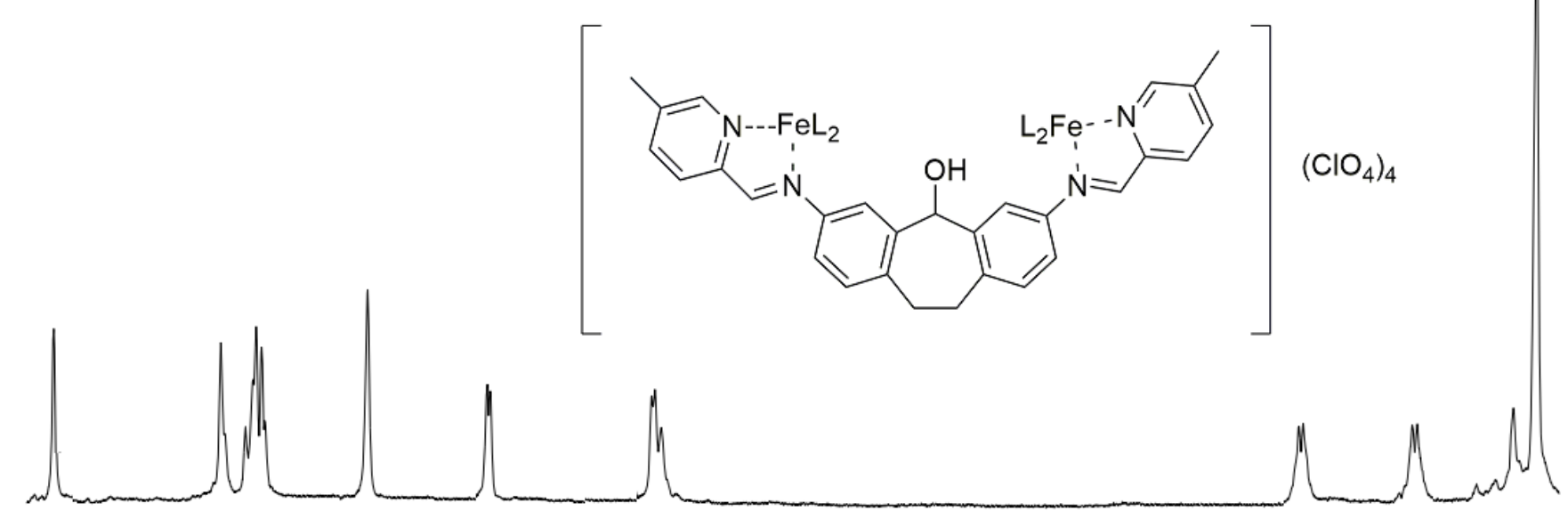

$\begin{array}{llllllllllllllllllllllllllllllllllllll}8.8 & 8.6 & 8.4 & 8.2 & 8.0 & 7.8 & 7.6 & 7.4 & 7.2 & 7.0 & 6.8 & 6.6 & 6.4 & 6.2 & 6.0 & 5.8 & 5.6 & 5.4 & 5.2 & 5.0 & 4.8 & 4.6 & 4.4 & 4.2 & 4.0 & 3.8 & 3.6 & 3.4 & 3.2 & 3.0 & 2.8 & 2.6 & 2.4\end{array}$

Figure S11. ${ }^{1} \mathrm{H}$ NMR spectrum of methyl-suberol meso-helicate $2 \cdot \mathrm{Me}_{6}\left(\mathrm{CD}_{3} \mathrm{CN}, 500 \mathrm{MHz}, 298 \mathrm{~K}\right)$.

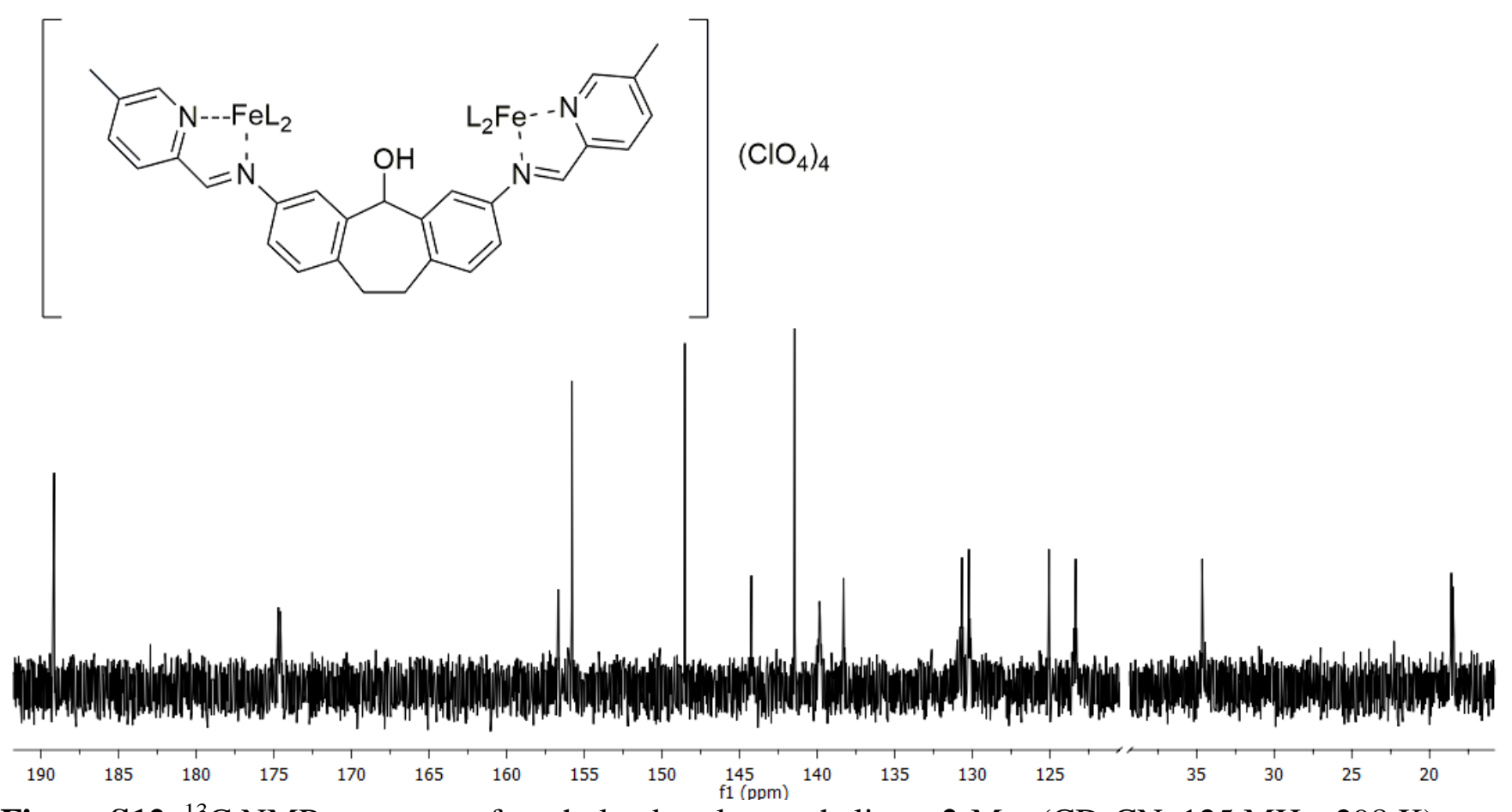

Figure S12. ${ }^{13} \mathrm{C}$ NMR spectrum of methyl-suberol meso-helicate $2 \cdot \mathrm{Me}_{6}\left(\mathrm{CD}_{3} \mathrm{CN}, 125 \mathrm{MHz}, 298 \mathrm{~K}\right)$. 


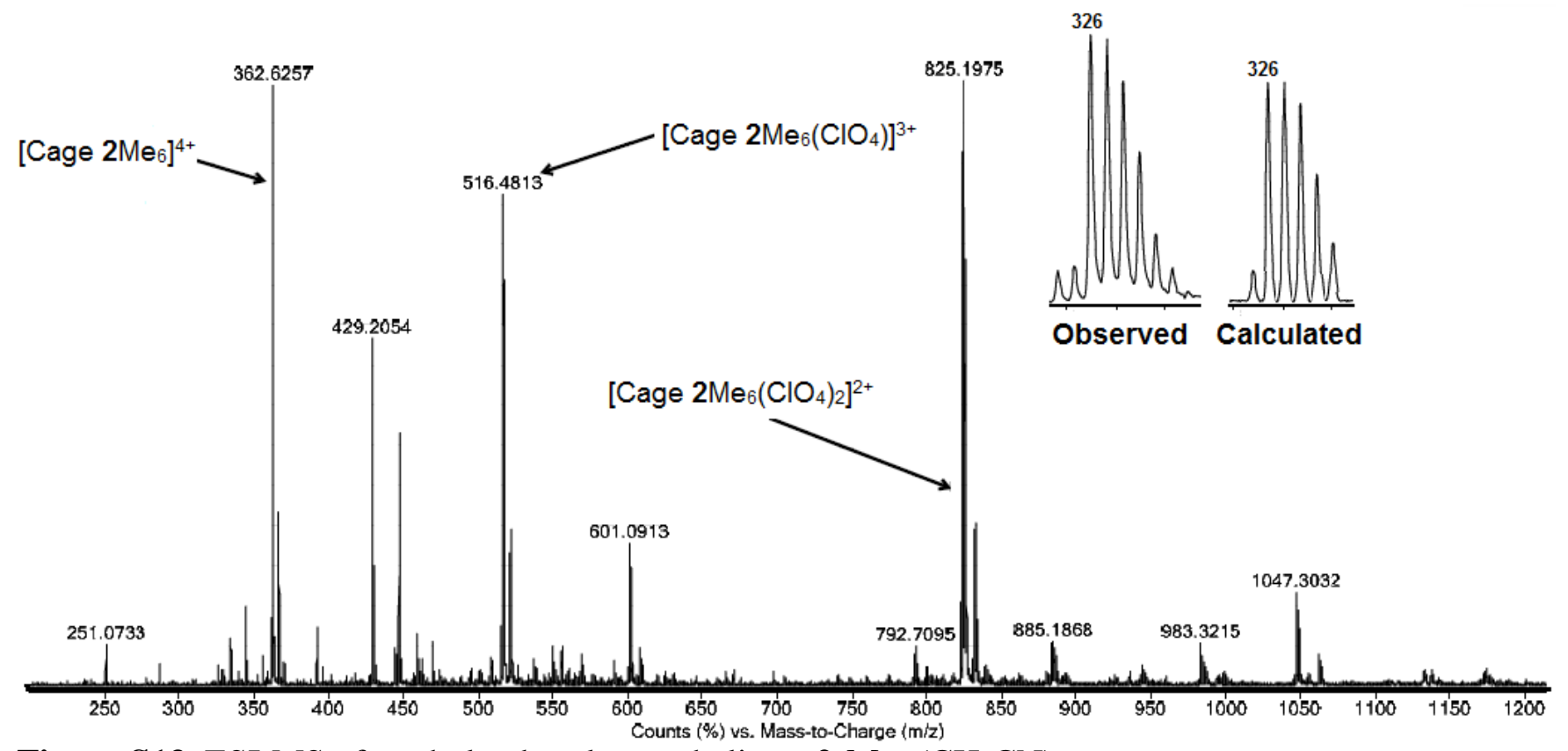

Figure S13. ESI-MS of methyl-suberol meso-helicate $2 \cdot \mathrm{Me}_{6}\left(\mathrm{CH}_{3} \mathrm{CN}\right)$.
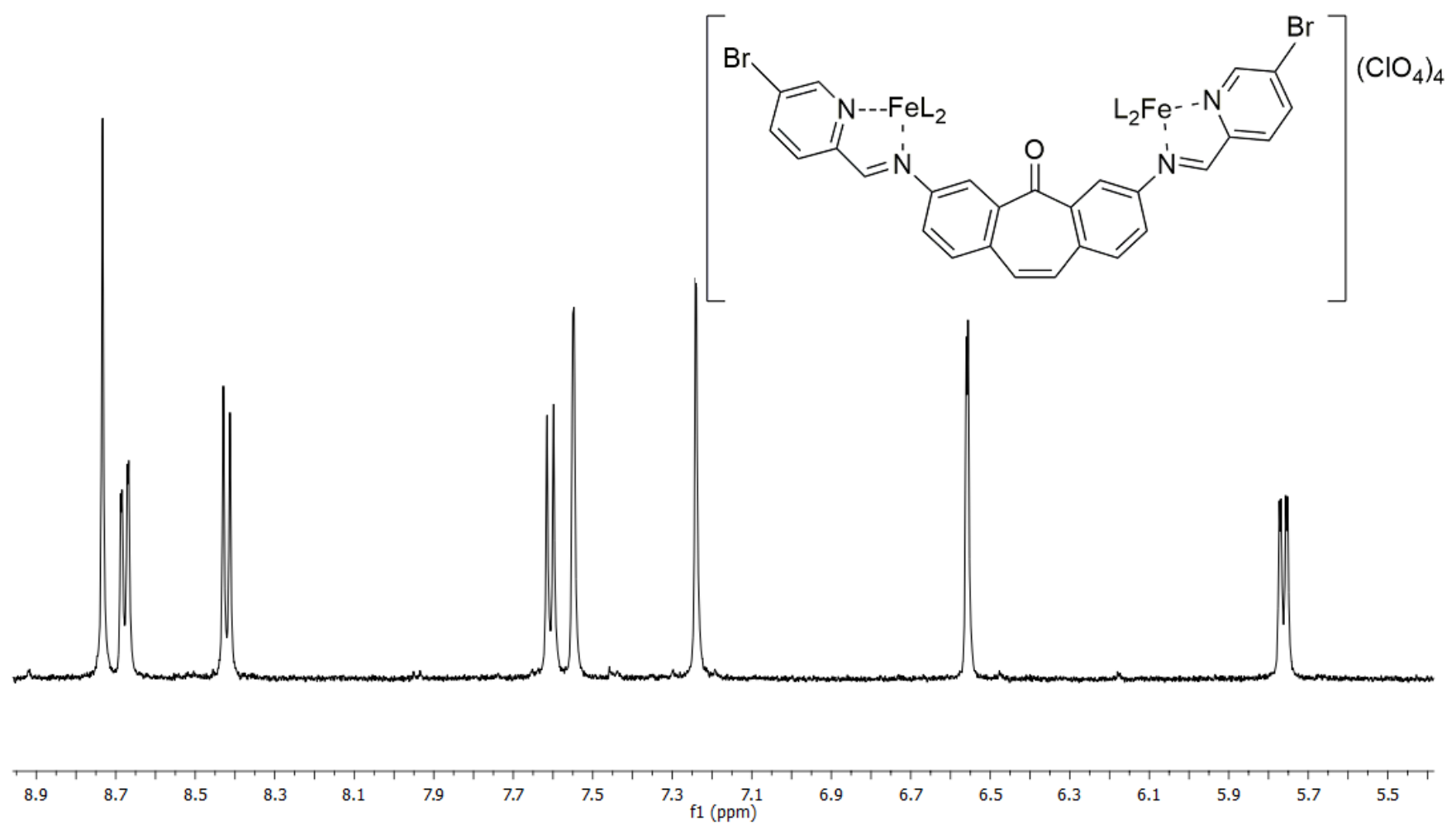

Figure S14. ${ }^{1} \mathrm{H}$ NMR spectrum of bromo-suberenone meso-helicate $\mathbf{3} \cdot \mathrm{Br}_{6}\left(\mathrm{CD}_{3} \mathrm{CN}, 500 \mathrm{MHz}, 298 \mathrm{~K}\right)$. 

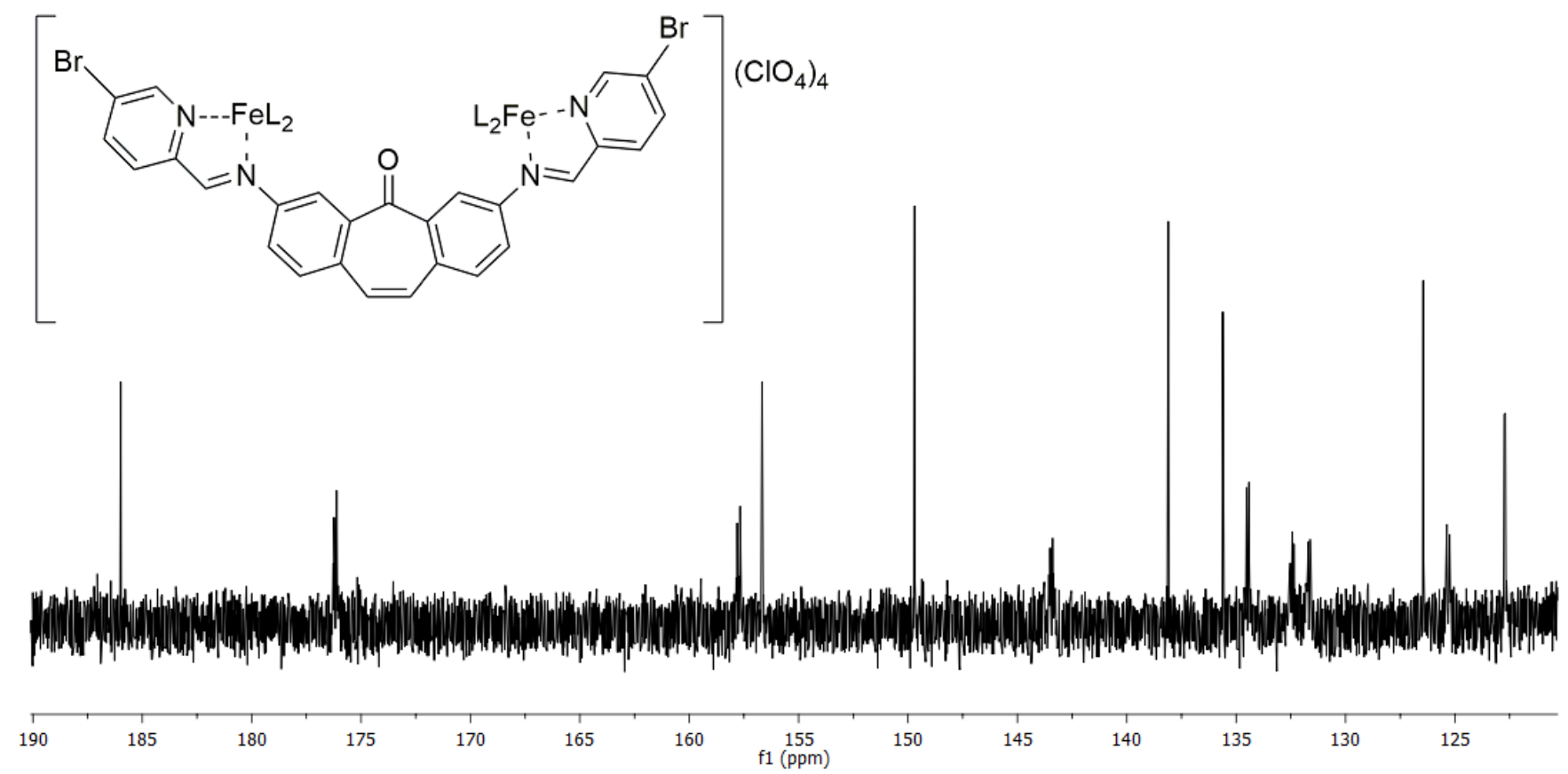

Figure S15. ${ }^{13} \mathrm{C}$ NMR spectrum of bromo-suberenone meso-helicate $\mathbf{3} \cdot \mathrm{Br}_{6}\left(\mathrm{CD}_{3} \mathrm{CN}, 125 \mathrm{MHz}, 298 \mathrm{~K}\right)$.

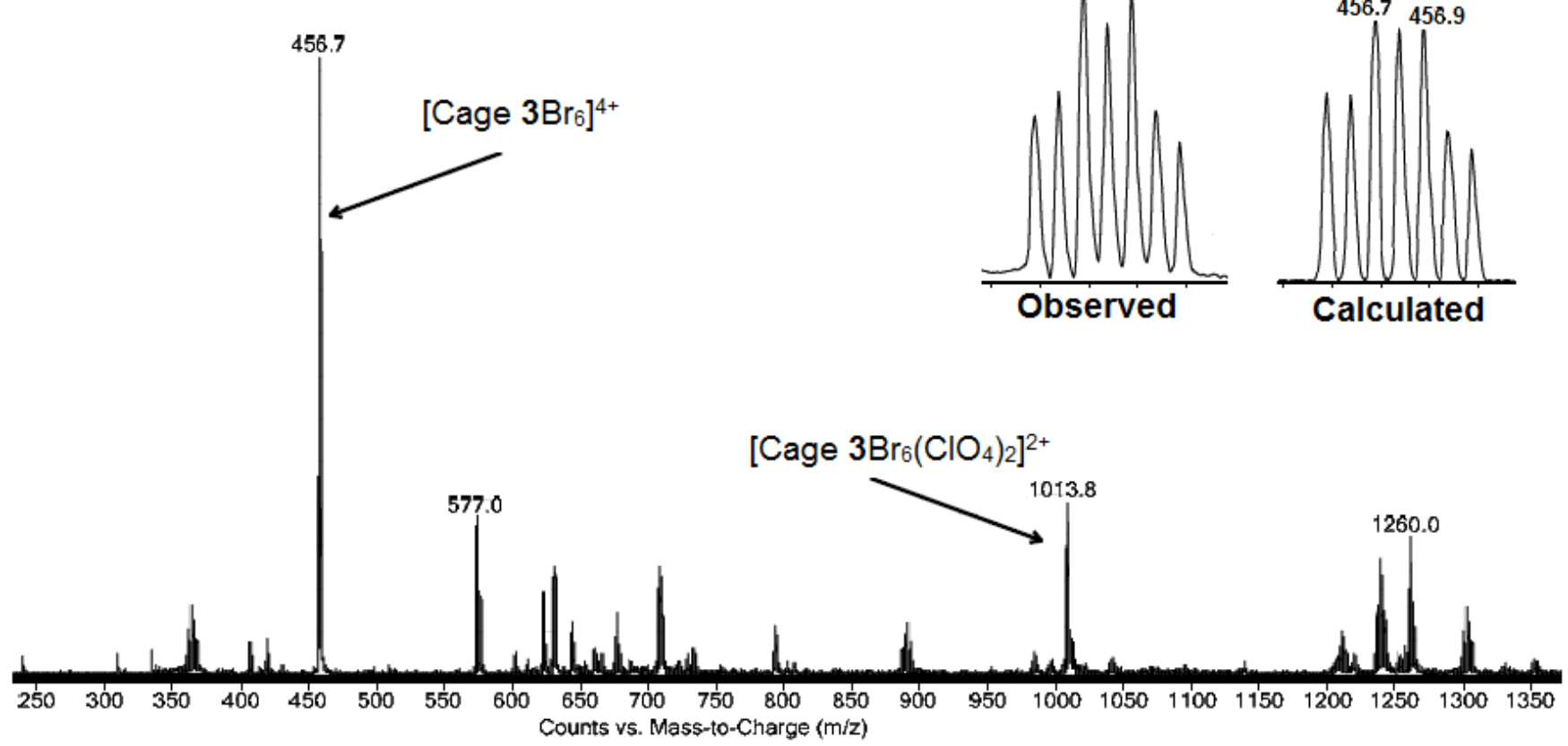

Figure S16. ESI-MS of bromo-suberenone meso-helicate $3 \cdot \mathrm{Br}_{6}\left(\mathrm{CH}_{3} \mathrm{CN}\right)$. 

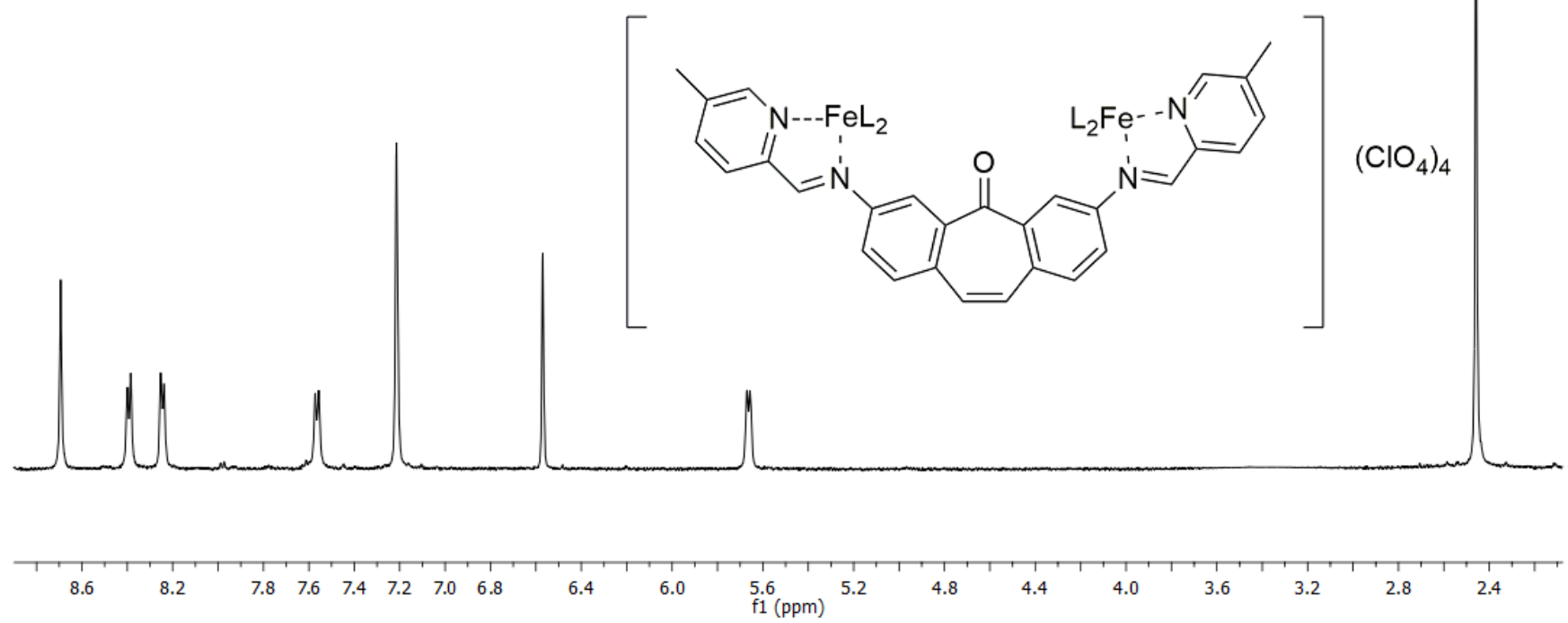

Figure S17. ${ }^{1} \mathrm{H}$ NMR spectrum of methyl-suberenone meso-helicate $3 \cdot \mathrm{Me}_{6}\left(\mathrm{CD}_{3} \mathrm{CN}, 500 \mathrm{MHz}, 298 \mathrm{~K}\right)$.

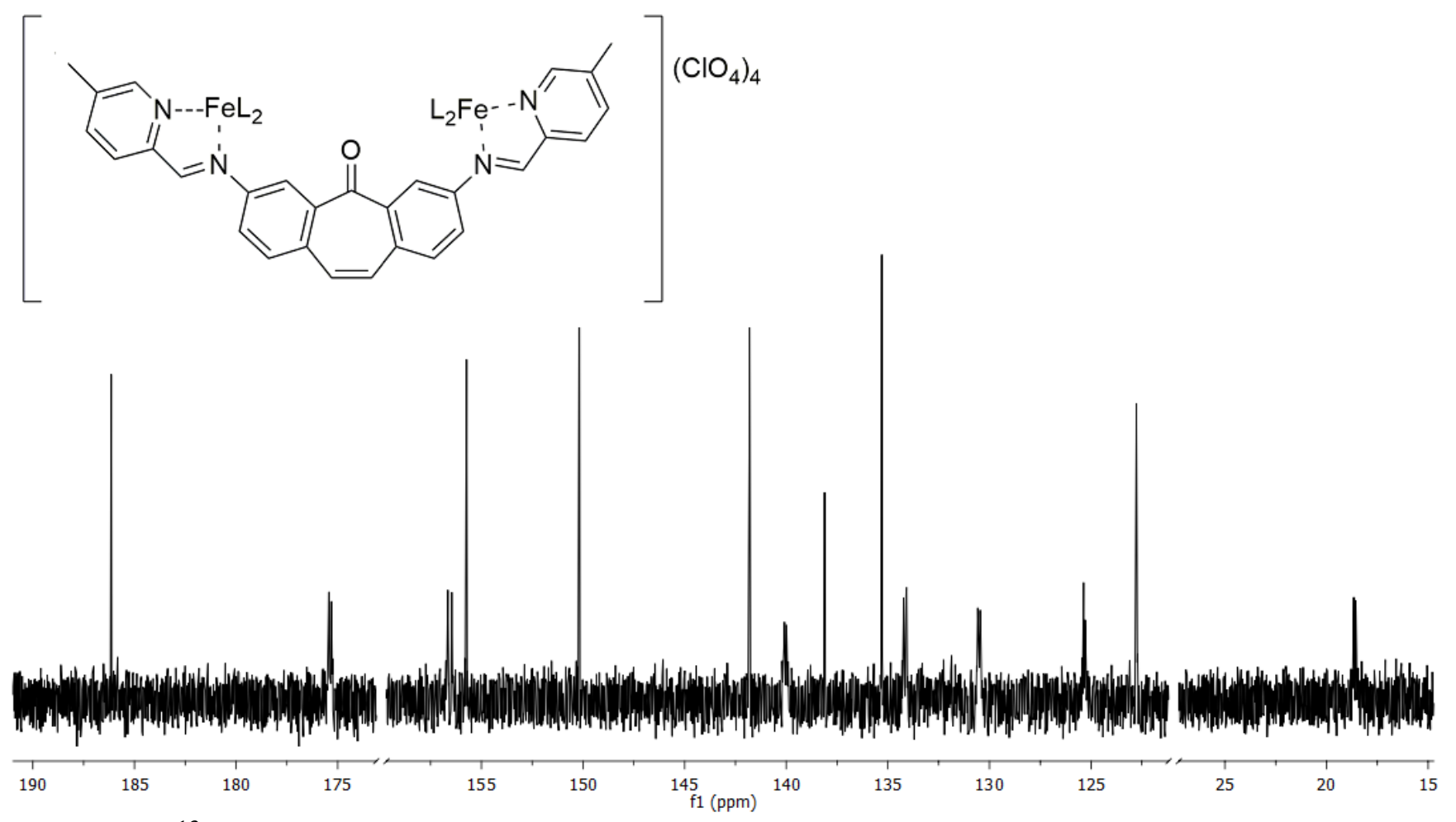

Figure S18. ${ }^{13} \mathrm{C}$ NMR spectrum of methyl-suberenone meso-helicate $3 \cdot \mathrm{Me}_{6}\left(\mathrm{CD}_{3} \mathrm{CN}, 125 \mathrm{MHz}, 298 \mathrm{~K}\right)$. 


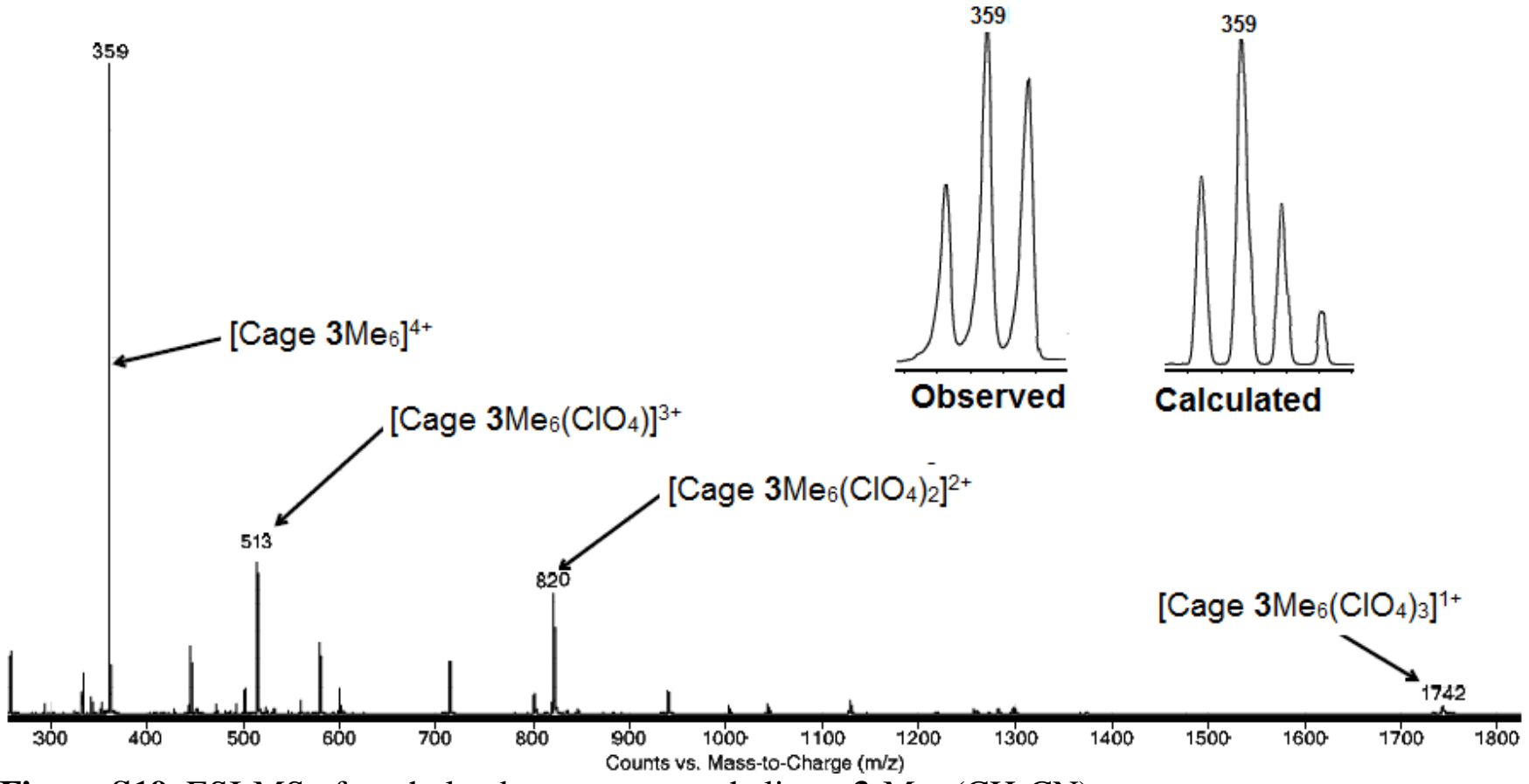

Figure S19. ESI-MS of methyl-suberenone meso-helicate $3 \cdot \mathrm{Me}_{6}\left(\mathrm{CH}_{3} \mathrm{CN}\right)$. 


\section{Kinetic Formation Experiments}

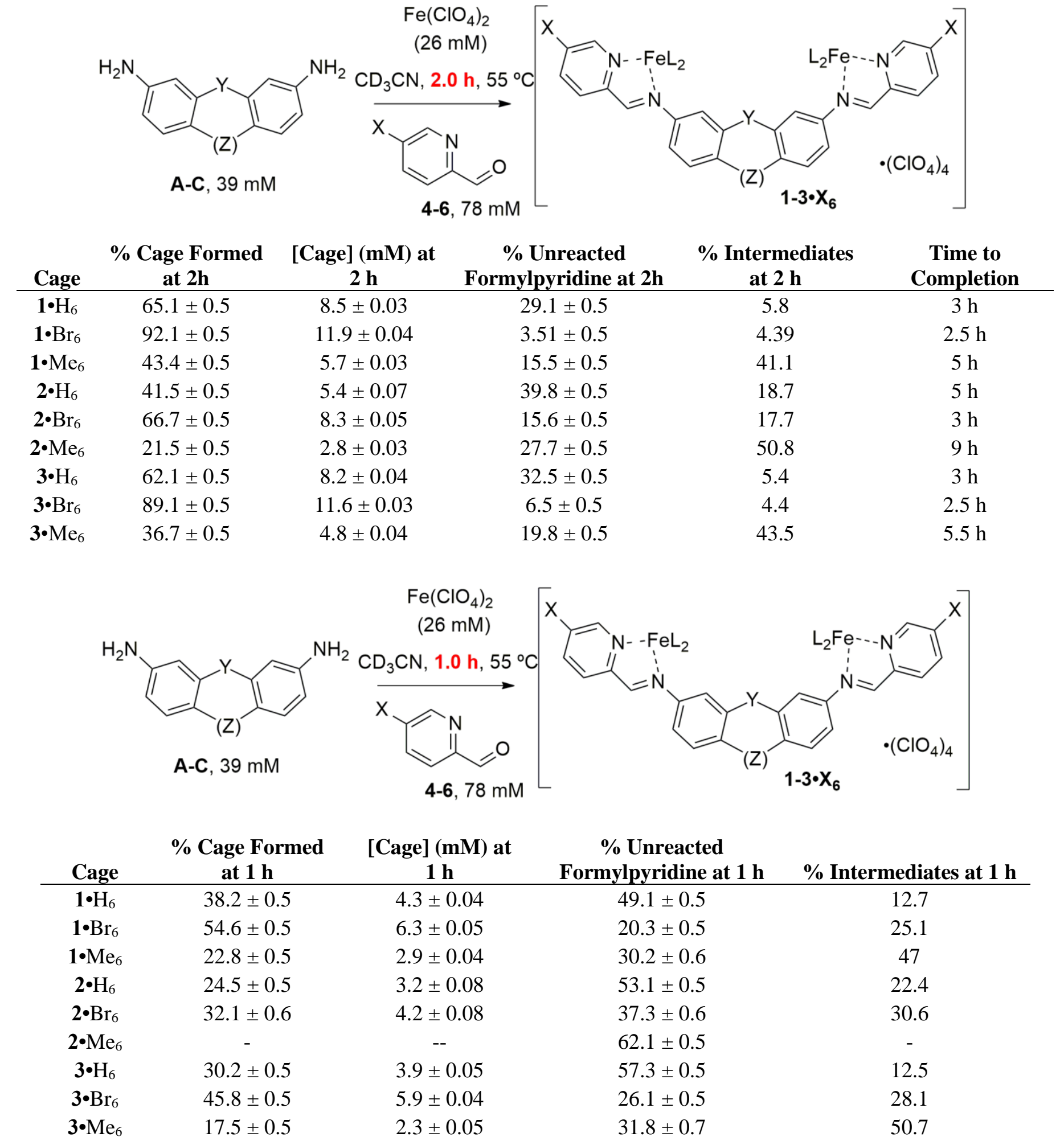




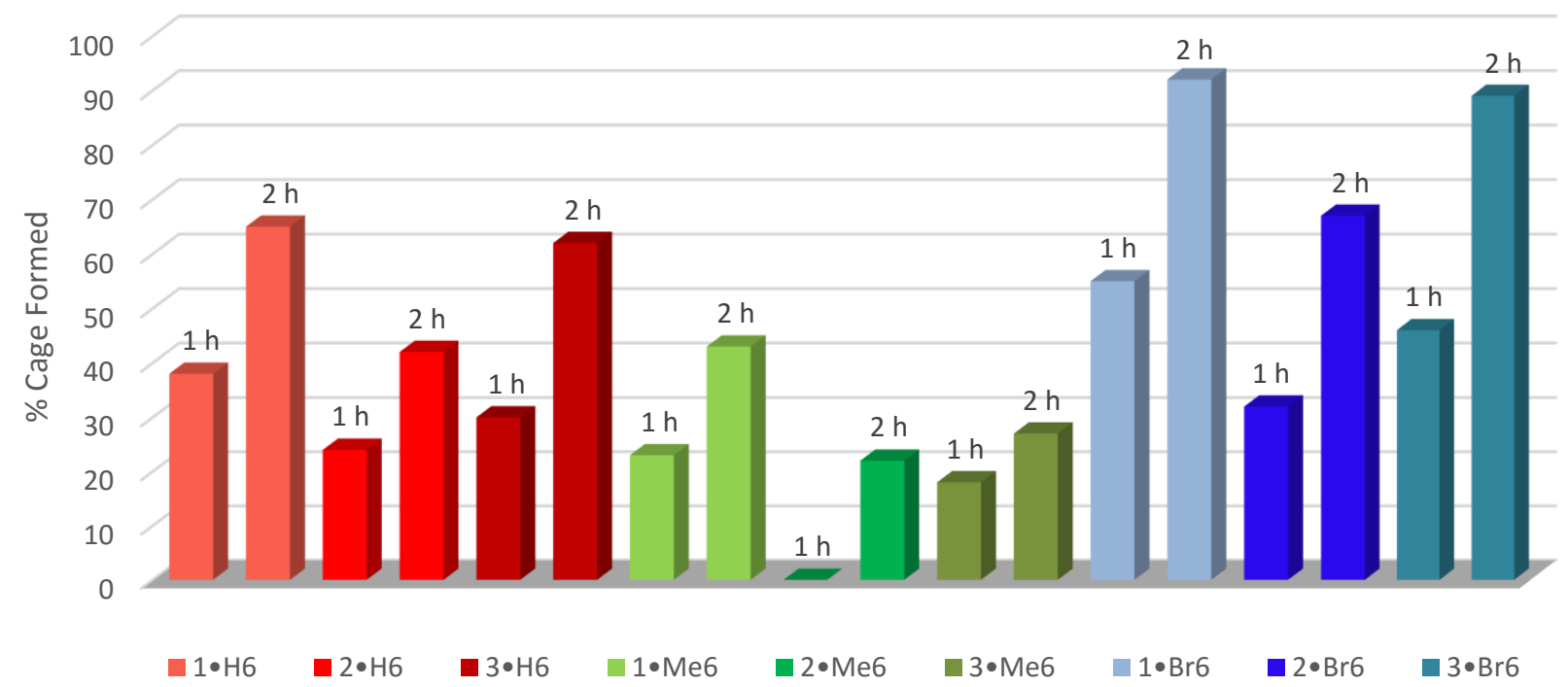

Figure S20. Plotted Summary of $2 \mathrm{~h}$ and $1 \mathrm{~h}$ kinetic formation Experiments.

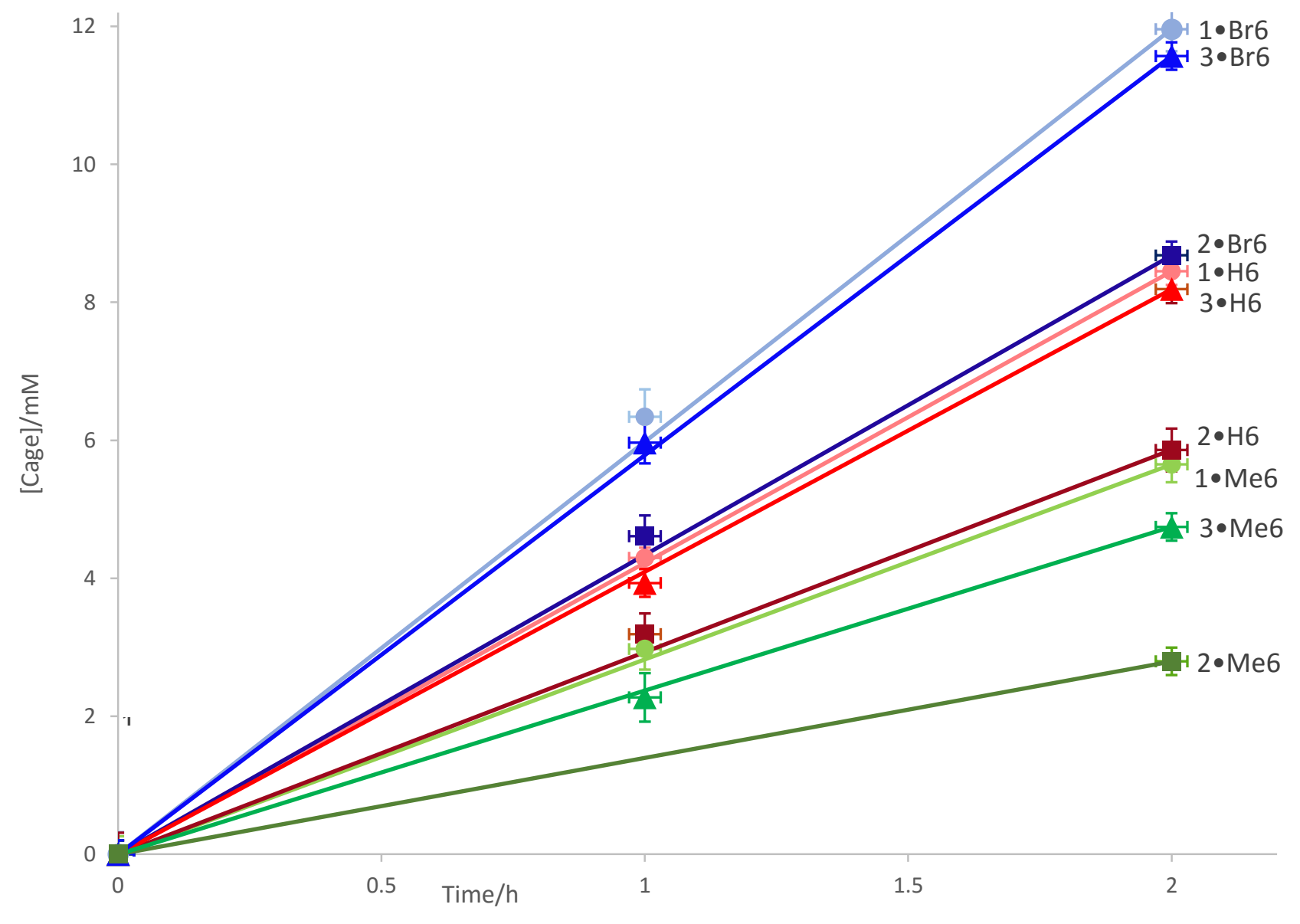

Figure S21. Comparison of linearity between 1 hour and 2 hour concentrations of cage product. 


\section{2b. Standardized 2 Hour Kinetic Formation Experiments}

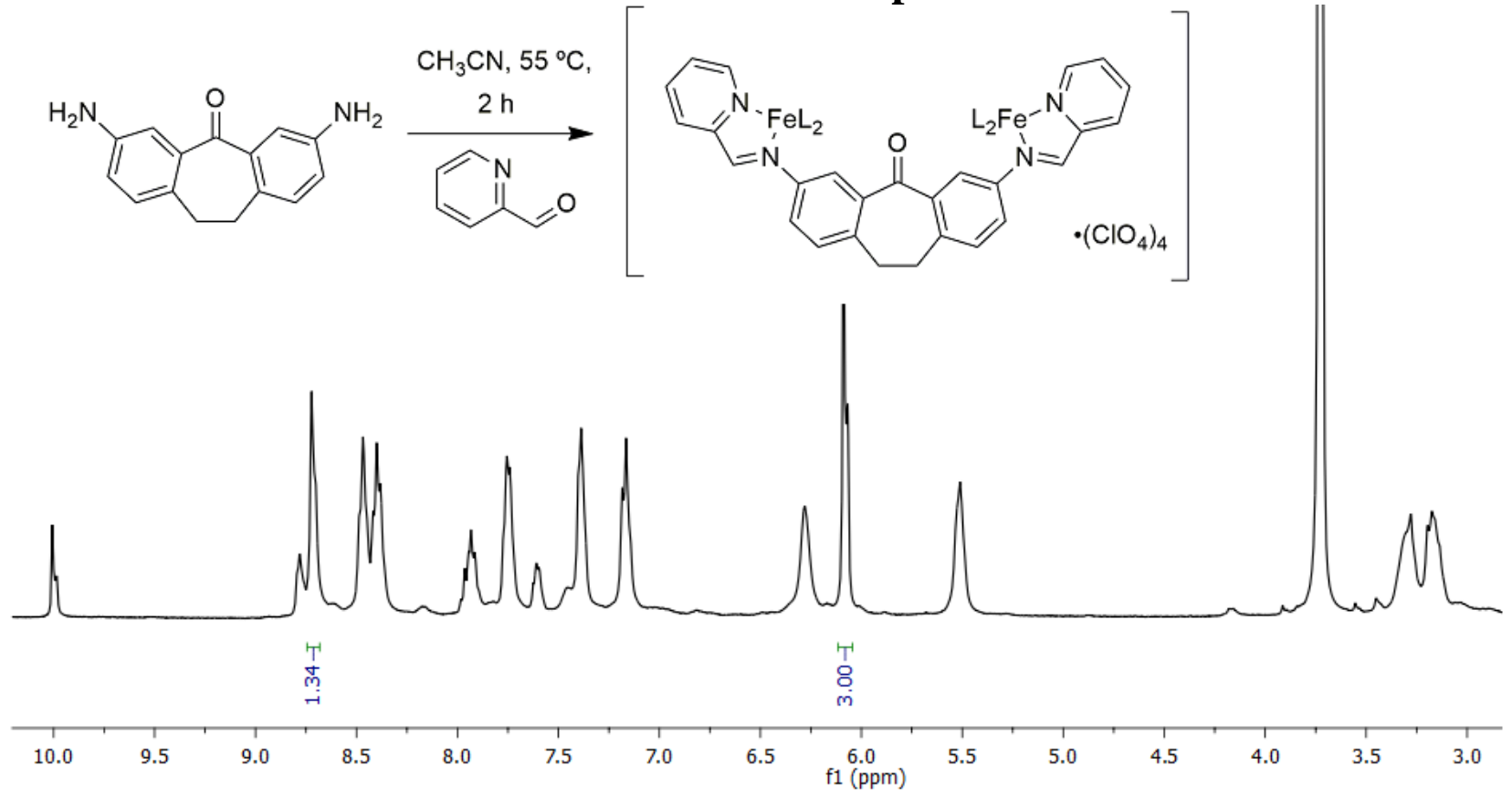

Figure S22. ${ }^{1} \mathrm{H}$ NMR spectra of products formed upon mixing suberone ligand $\mathbf{A}$ and formylpyridine 4 with $\mathrm{Fe}\left(\mathrm{ClO}_{4}\right)_{2}$ and 1,3,5-trimethoxybenzene and heating at $55^{\circ} \mathrm{C}$ for 2 hours $\left(\mathrm{CD}_{3} \mathrm{CN}, 400 \mathrm{MHz}, 298 \mathrm{~K}\right)$.

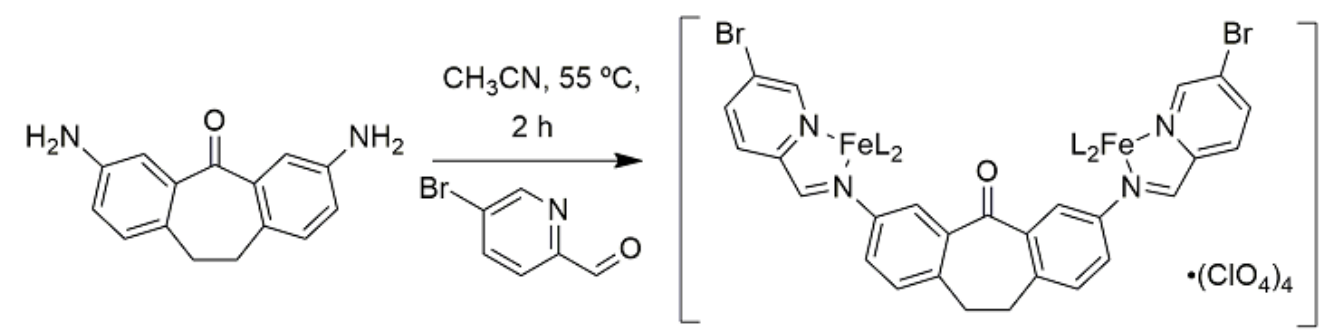

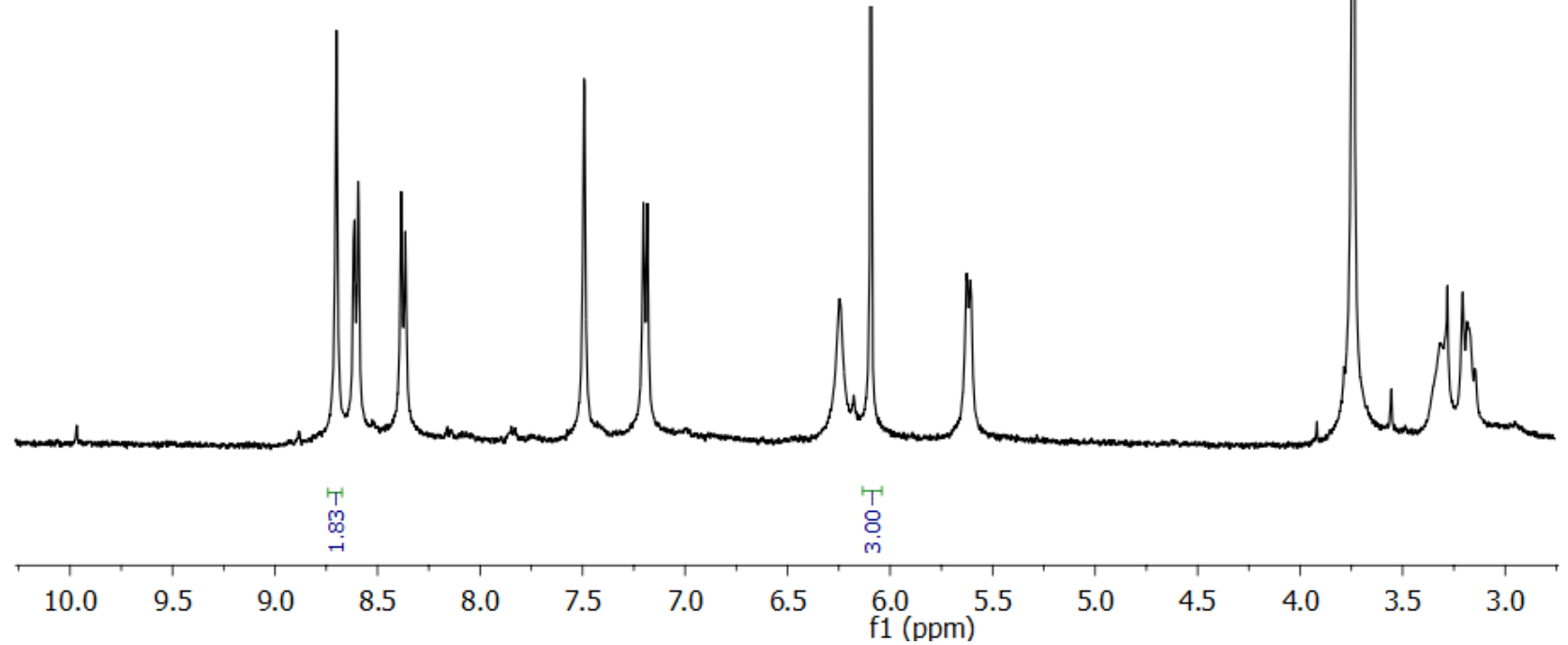

Figure S23. ${ }^{1} \mathrm{H}$ NMR spectra of products formed upon mixing suberone ligand A and bromoformylpyridine 5 with $\mathrm{Fe}\left(\mathrm{ClO}_{4}\right)_{2}$ and 1,3,5-trimethoxybenzene standard, and heating at $55^{\circ} \mathrm{C}$ for 2 hours $\left(\mathrm{CD}_{3} \mathrm{CN}, 400 \mathrm{MHz}, 298 \mathrm{~K}\right)$. 


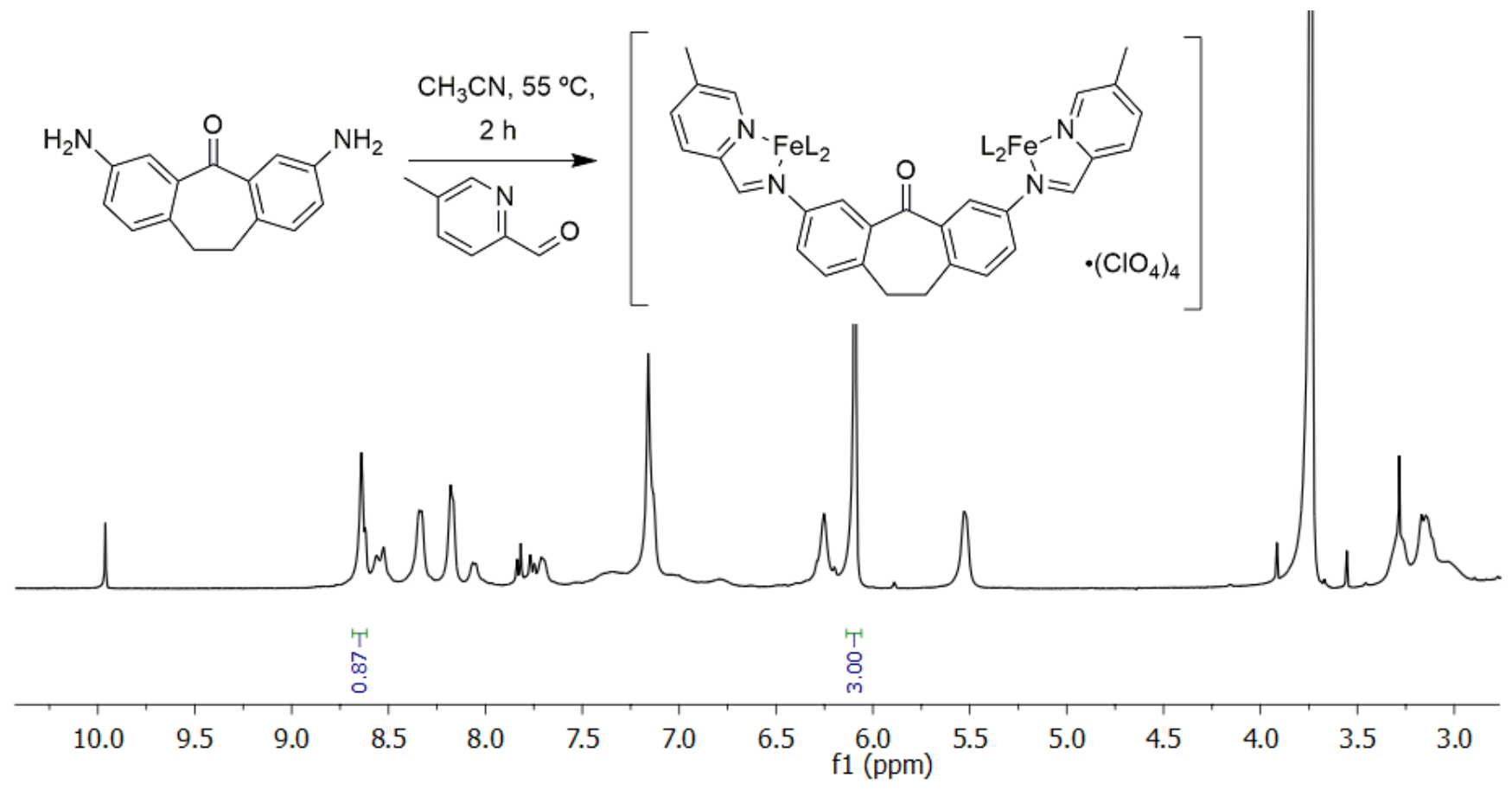

Figure S24. ${ }^{1} \mathrm{H}$ NMR spectra of products formed upon mixing suberone ligand A and methylformylpyridine 6 with $\mathrm{Fe}\left(\mathrm{ClO}_{4}\right)_{2}$ and 1,3,5-trimethoxybenzene standard, and heating at $55{ }^{\circ} \mathrm{C}$ for 2 hours $\left(\mathrm{CD}_{3} \mathrm{CN}, 400 \mathrm{MHz}, 298 \mathrm{~K}\right)$.
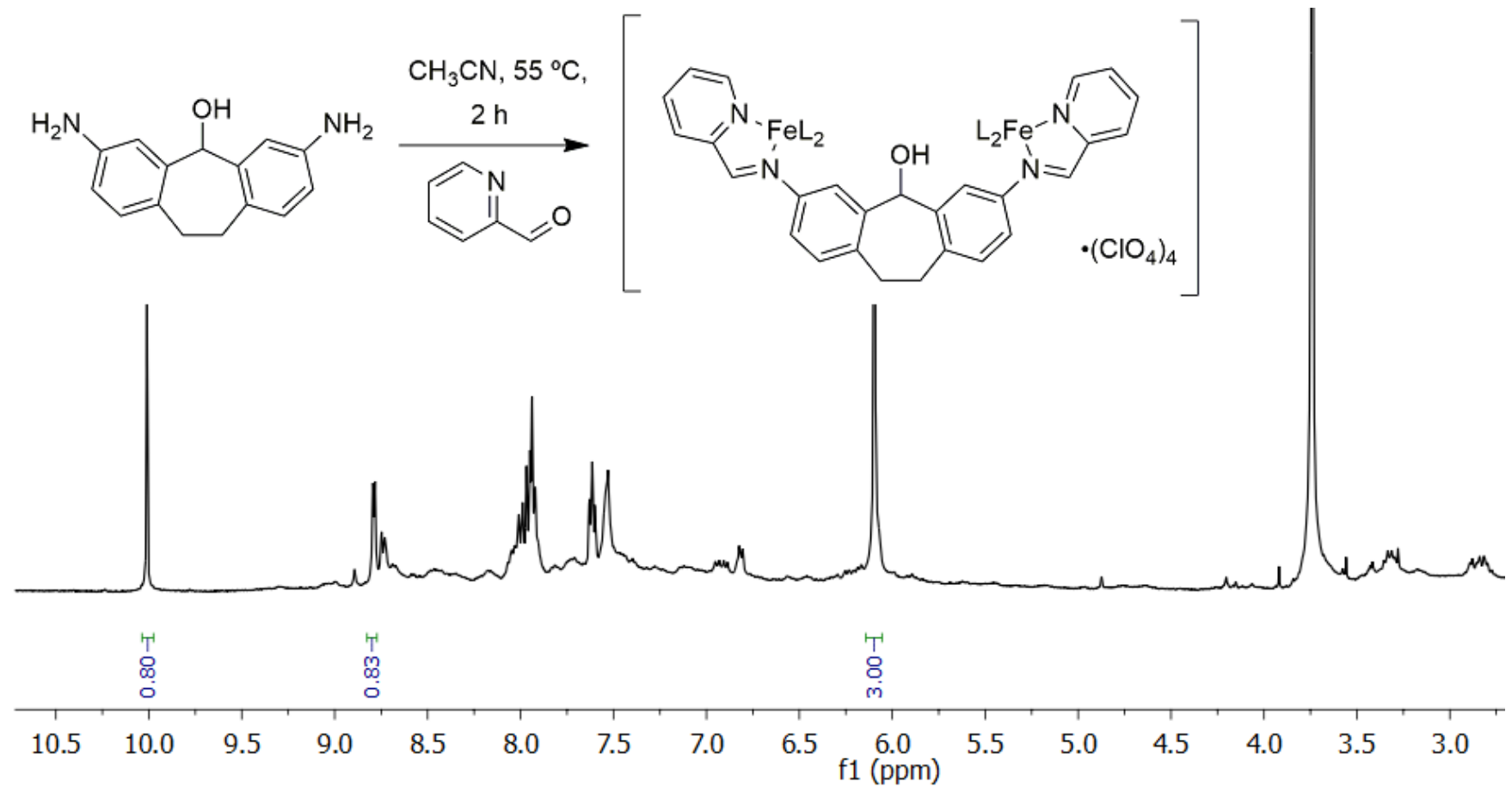

Figure S25. ${ }^{1} \mathrm{H}$ NMR spectra of products formed upon mixing suberol ligand $\mathbf{B}$ and formylpyridine $\mathbf{4}$ with $\mathrm{Fe}\left(\mathrm{ClO}_{4}\right)_{2}$ and 1,3,5-trimethoxybenzene standard, and heating at $55{ }^{\circ} \mathrm{C}$ for 2 hours $\left(\mathrm{CD}_{3} \mathrm{CN}, 400 \mathrm{MHz}\right.$, $298 \mathrm{~K})$. 


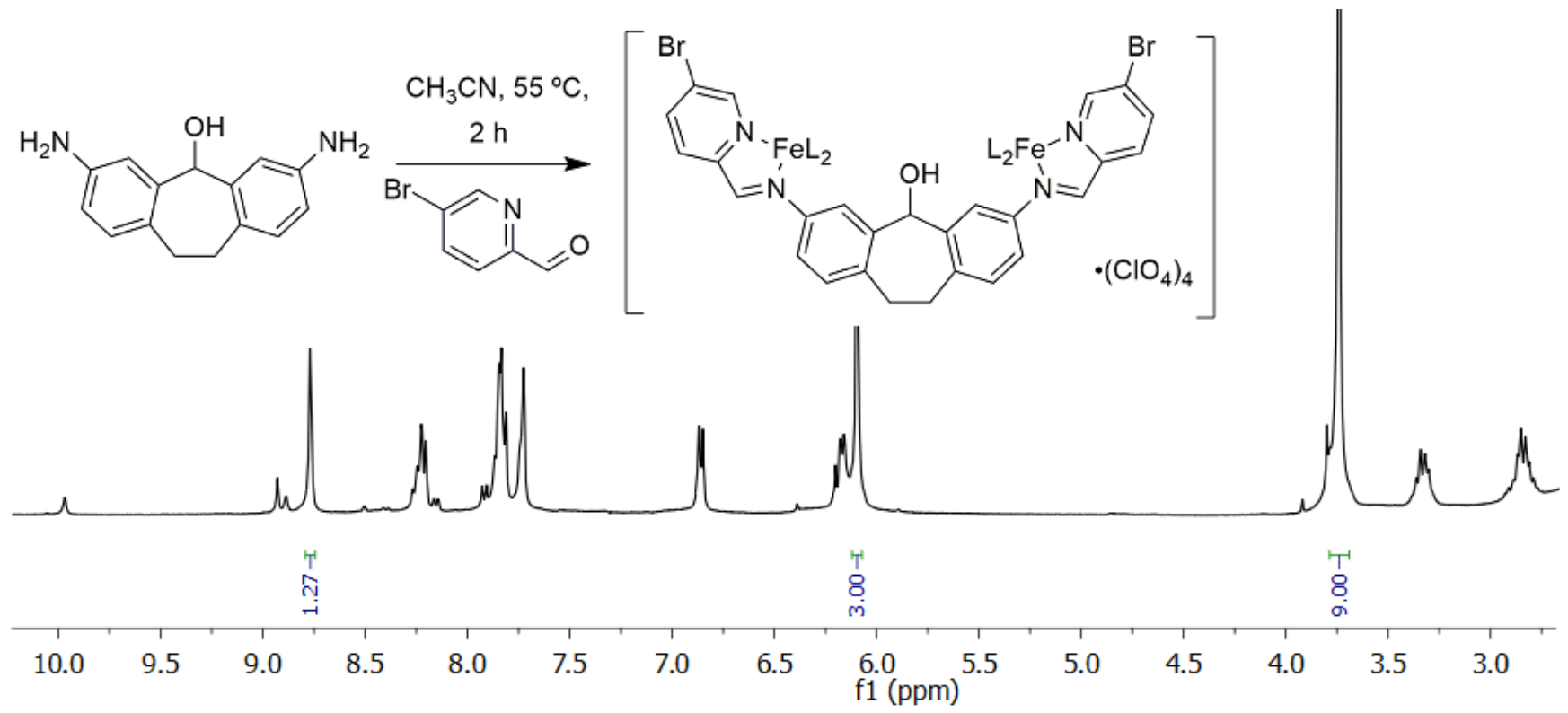

Figure S26. ${ }^{1} \mathrm{H}$ NMR spectra of products formed upon mixing suberol ligand $\mathbf{B}$ and bromo-formylpyridine 5 with $\mathrm{Fe}\left(\mathrm{ClO}_{4}\right)_{2}$ and 1,3,5-trimethoxybenzene standard, and heating at $55{ }^{\circ} \mathrm{C}$ for 2 hours $\left(\mathrm{CD}_{3} \mathrm{CN}, 400\right.$ $\mathrm{MHz}, 298 \mathrm{~K})$.

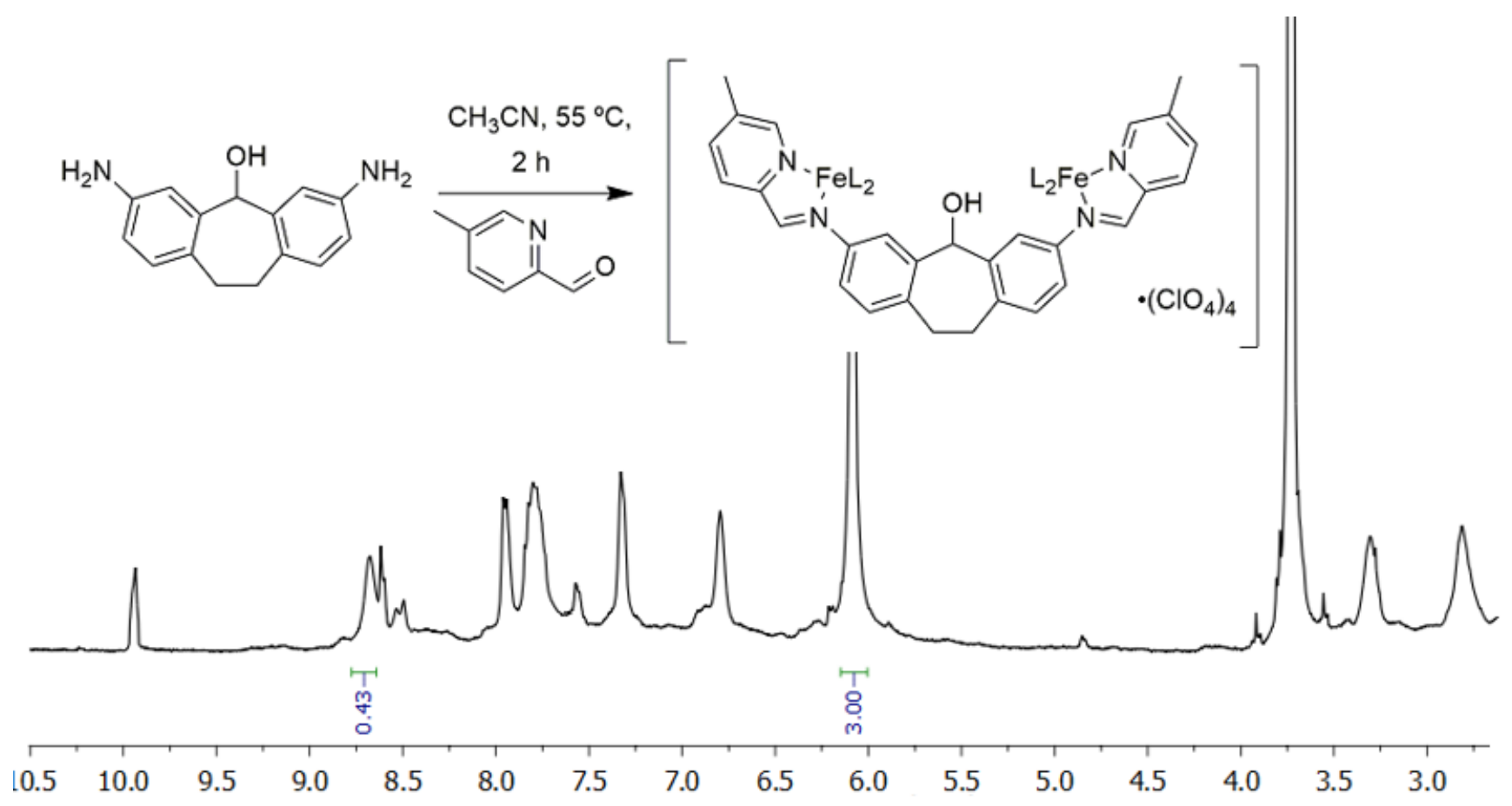

Figure S27. ${ }^{1} \mathrm{H}$ NMR spectra of products formed upon mixing suberol ligand $\mathbf{B}$ and methylformylpyridine $\mathbf{6}$ with $\mathrm{Fe}\left(\mathrm{ClO}_{4}\right)_{2}$ and 1,3,5-trimethoxybenzene standard, and heating at $55^{\circ} \mathrm{C}$ for 2 hours $\left(\mathrm{CD}_{3} \mathrm{CN}, 400 \mathrm{MHz}, 298 \mathrm{~K}\right)$. 


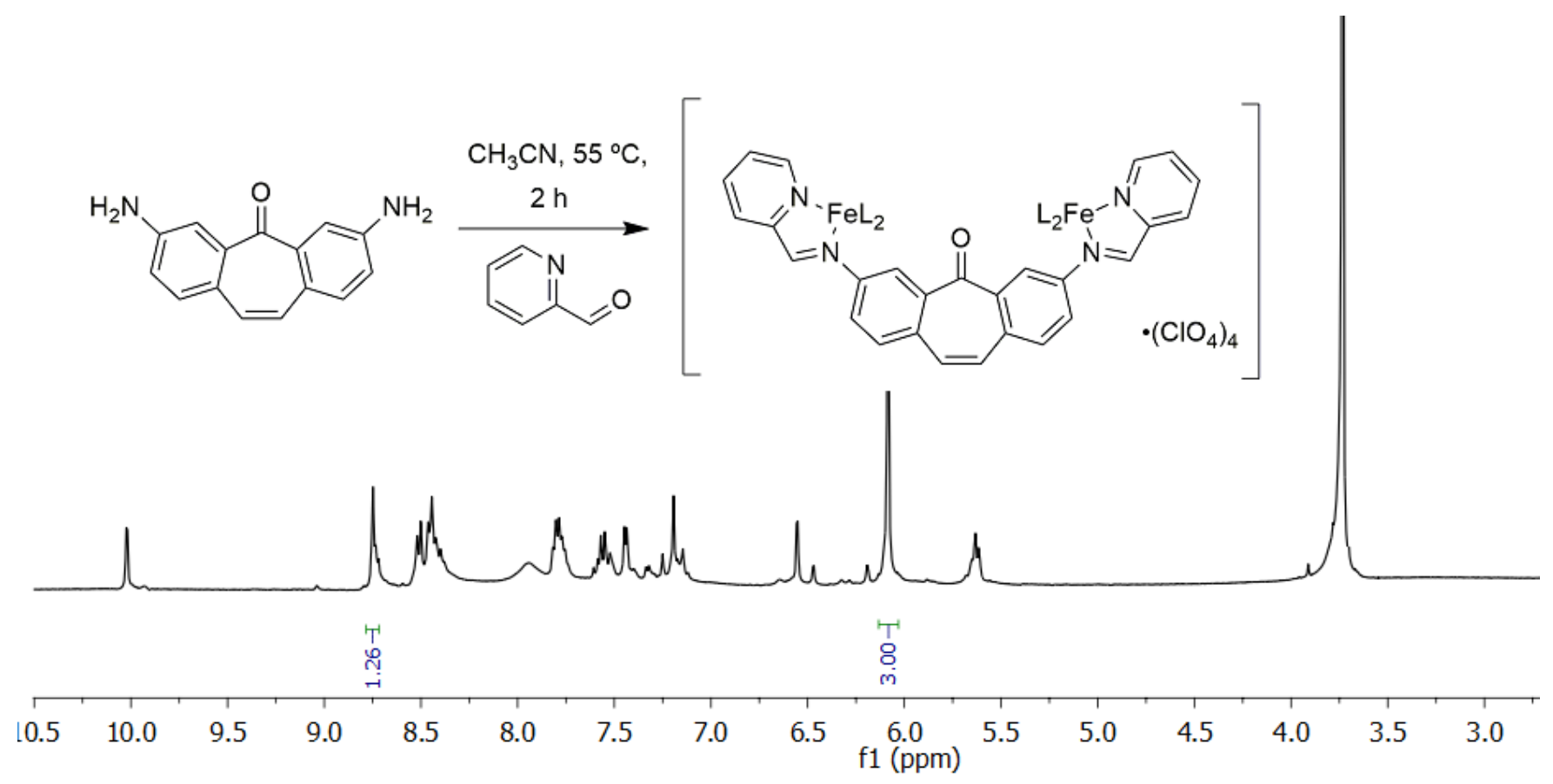

Figure S28. ${ }^{1} \mathrm{H}$ NMR spectra of products formed upon mixing suberenone ligand $\mathbf{C}$ and formylpyridine 4 with $\mathrm{Fe}\left(\mathrm{ClO}_{4}\right)_{2}$ and 1,3,5-trimethoxybenzene standard, and heating at $55{ }^{\circ} \mathrm{C}$ for 2 hours $\left(\mathrm{CD}_{3} \mathrm{CN}, 400\right.$ $\mathrm{MHz}, 298 \mathrm{~K})$.

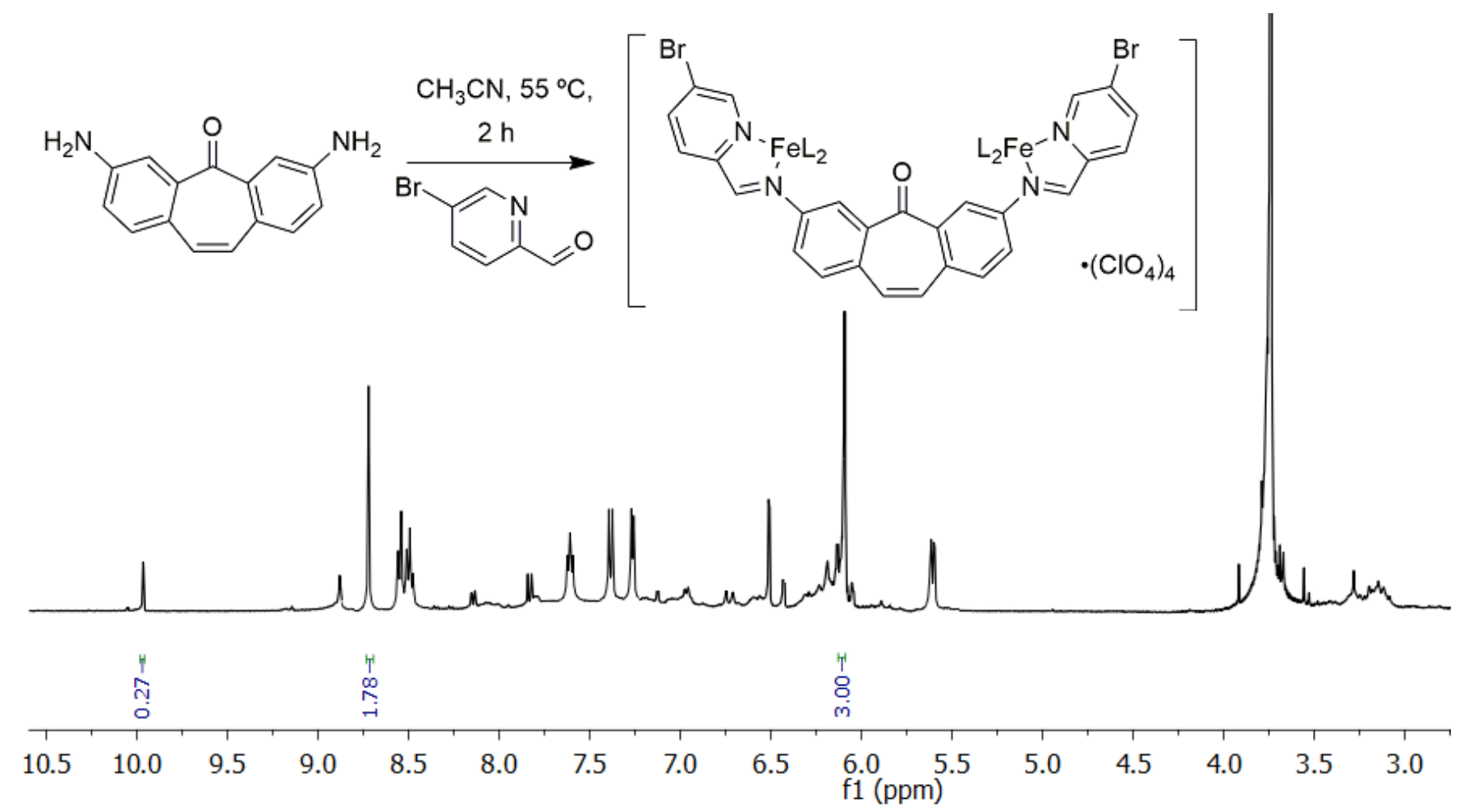

Figure S29. ${ }^{1} \mathrm{H}$ NMR spectra of products formed upon mixing suberenone ligand $\mathbf{C}$ and bromoformylpyridine 5 with $\mathrm{Fe}\left(\mathrm{ClO}_{4}\right)_{2}$ and 1,3,5-trimethoxybenzene standard, and heating at $55{ }^{\circ} \mathrm{C}$ for 2 hours $\left(\mathrm{CD}_{3} \mathrm{CN}, 400 \mathrm{MHz}, 298 \mathrm{~K}\right)$. 


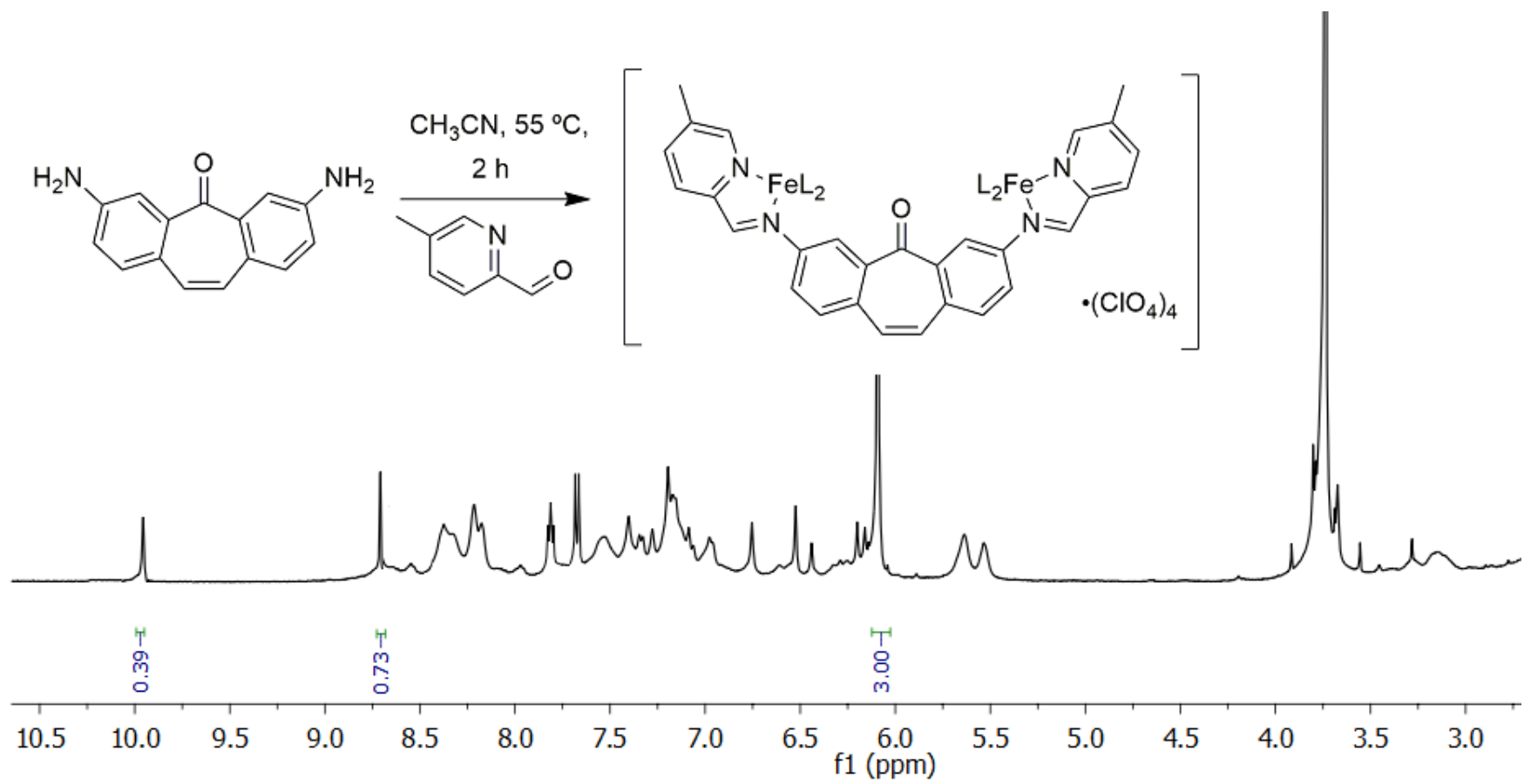

Figure S30. ${ }^{1} \mathrm{H}$ NMR spectra of products formed upon mixing suberenone ligand $\mathbf{C}$ and methylformylpyridine 6 with $\mathrm{Fe}\left(\mathrm{ClO}_{4}\right)_{2}$ and 1,3,5-trimethoxybenzene standard, and heating at $55{ }^{\circ} \mathrm{C}$ for 2 hours (CD $\left.{ }_{3} \mathrm{CN}, 400 \mathrm{MHz}, 298 \mathrm{~K}\right)$. 


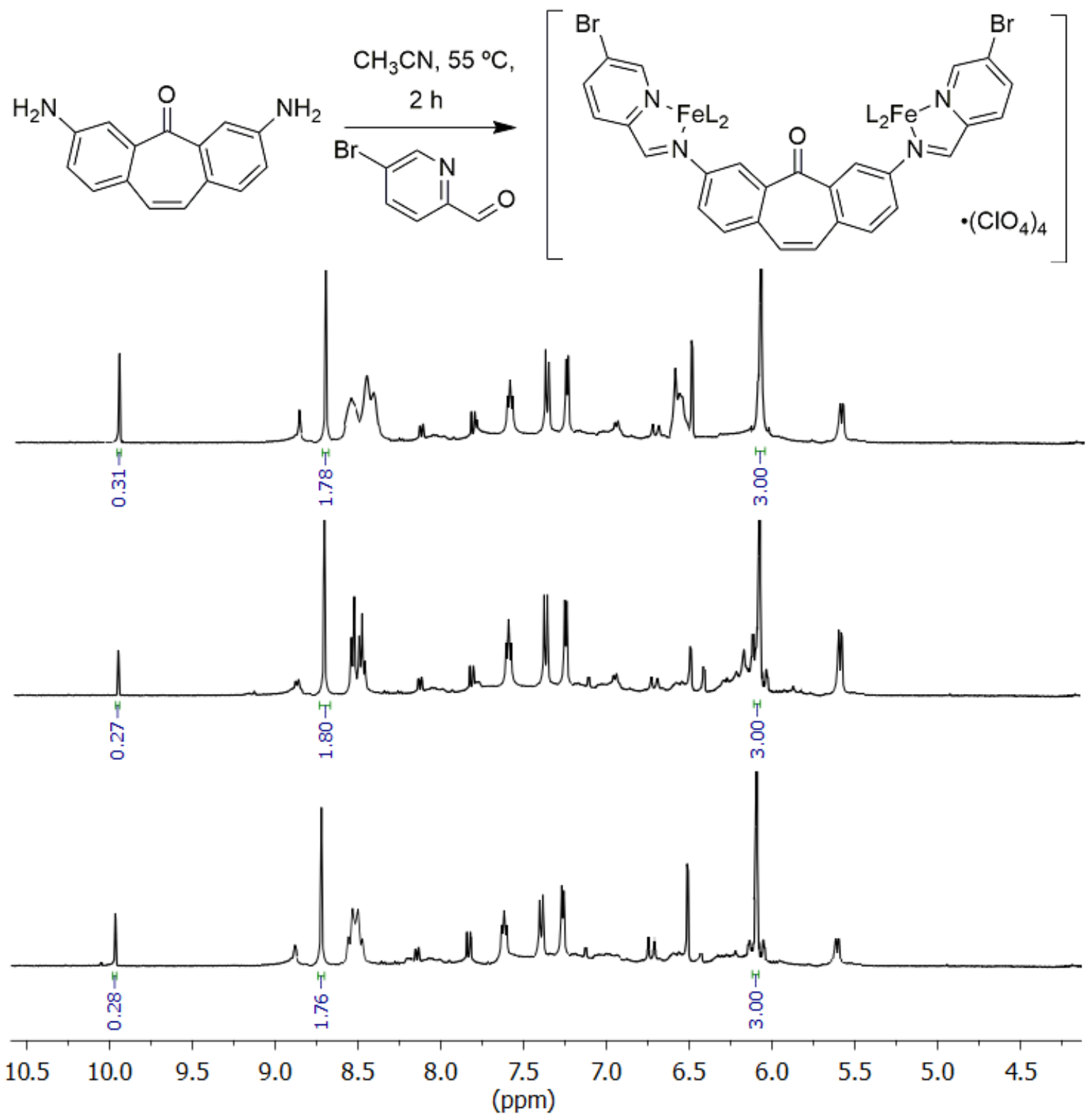

Figure S31. ${ }^{1} \mathrm{H}$ NMR spectra of triplicate runs of suberenone ligand $\mathbf{C}$ mixed with methyl-formylpyridine 6, $\mathrm{Fe}\left(\mathrm{ClO}_{4}\right)_{2}$ and 1,3,5-trimethoxybenzene standard, and heating at $55^{\circ} \mathrm{C}$ for 2 hours $\left(\mathrm{CD}_{3} \mathrm{CN}, 400 \mathrm{MHz}\right.$, $298 \mathrm{~K}$ ). 


\section{2c. Standardized 1 Hour Kinetic Formation Experiments}

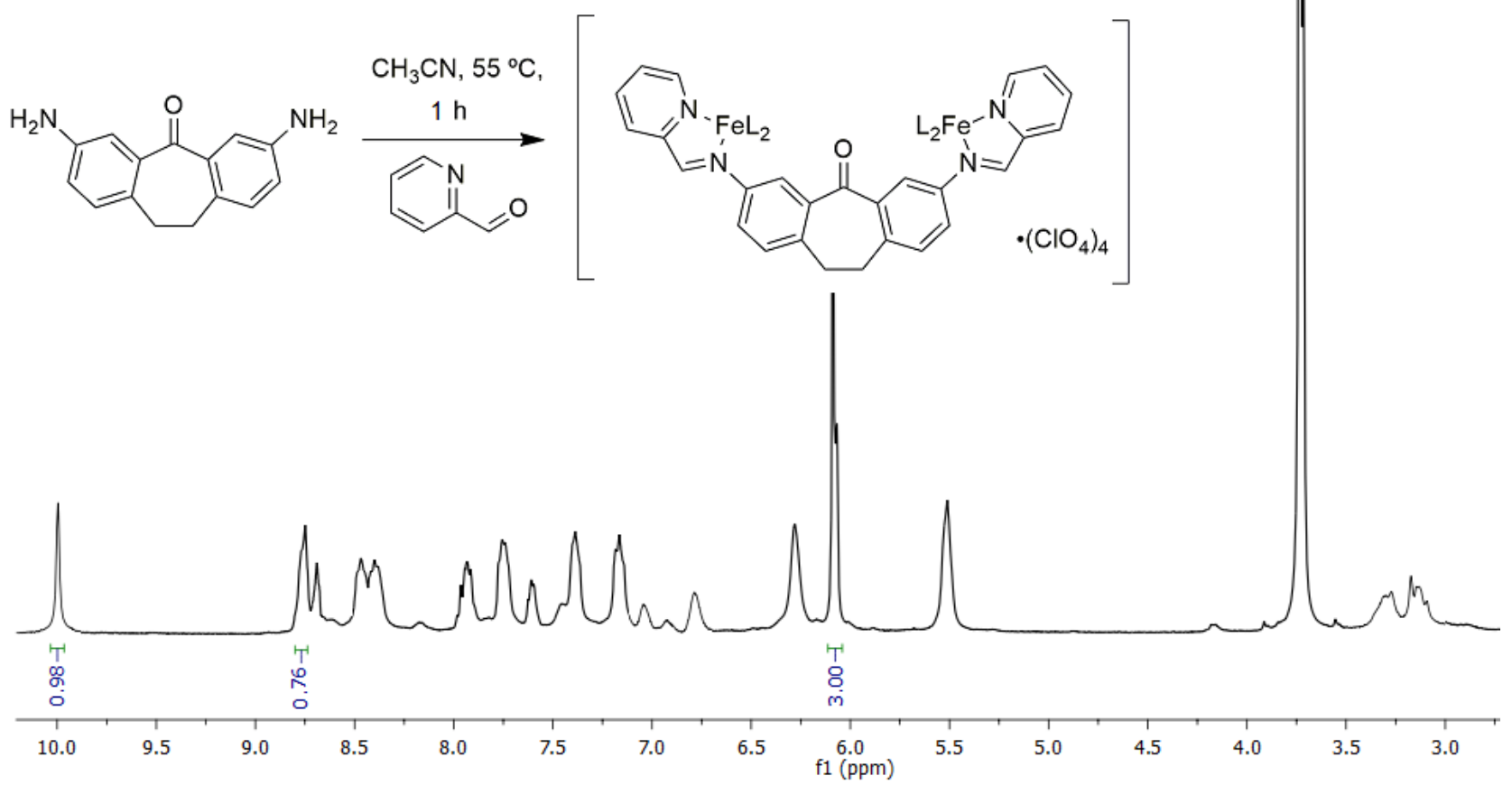

Figure S32. ${ }^{1} \mathrm{H}$ NMR spectra of products formed upon mixing suberone ligand A, formylpyridine 4, $\mathrm{Fe}\left(\mathrm{ClO}_{4}\right)_{2}$ and 1,3,5-trimethoxybenzene, and heating at $55^{\circ} \mathrm{C}$ for 1 hour $\left(\mathrm{CD}_{3} \mathrm{CN}, 400 \mathrm{MHz}, 298 \mathrm{~K}\right)$.

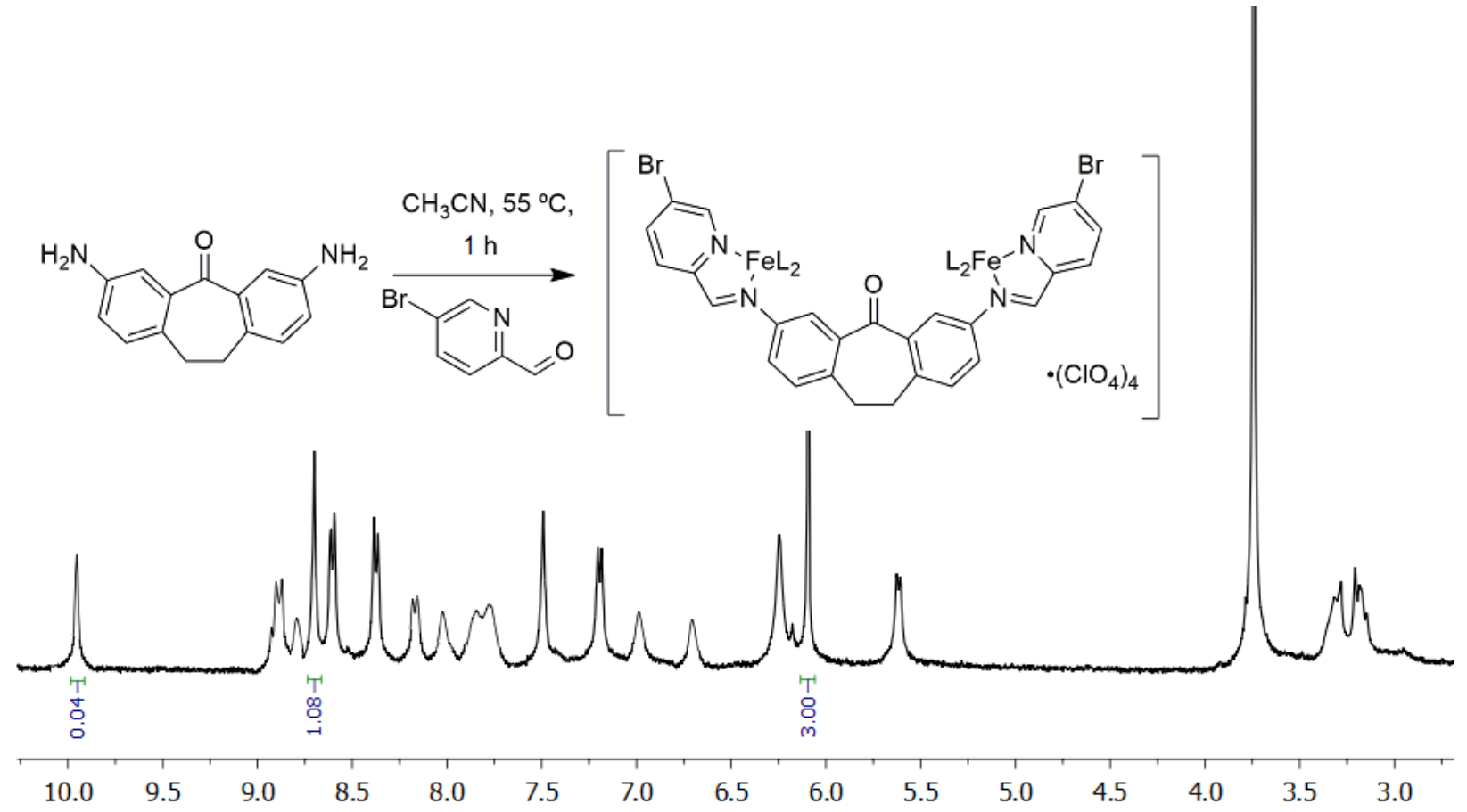

Figure S33. ${ }^{1} \mathrm{H}$ NMR spectra of products formed upon mixing suberone ligand $\mathrm{A}$, bromo-formylpyridine 5, $\mathrm{Fe}\left(\mathrm{ClO}_{4}\right)_{2}$ and 1,3,5-trimethoxybenzene, and heating at $55^{\circ} \mathrm{C}$ for 1 hour $\left(\mathrm{CD}_{3} \mathrm{CN}, 400 \mathrm{MHz}, 298 \mathrm{~K}\right)$. 


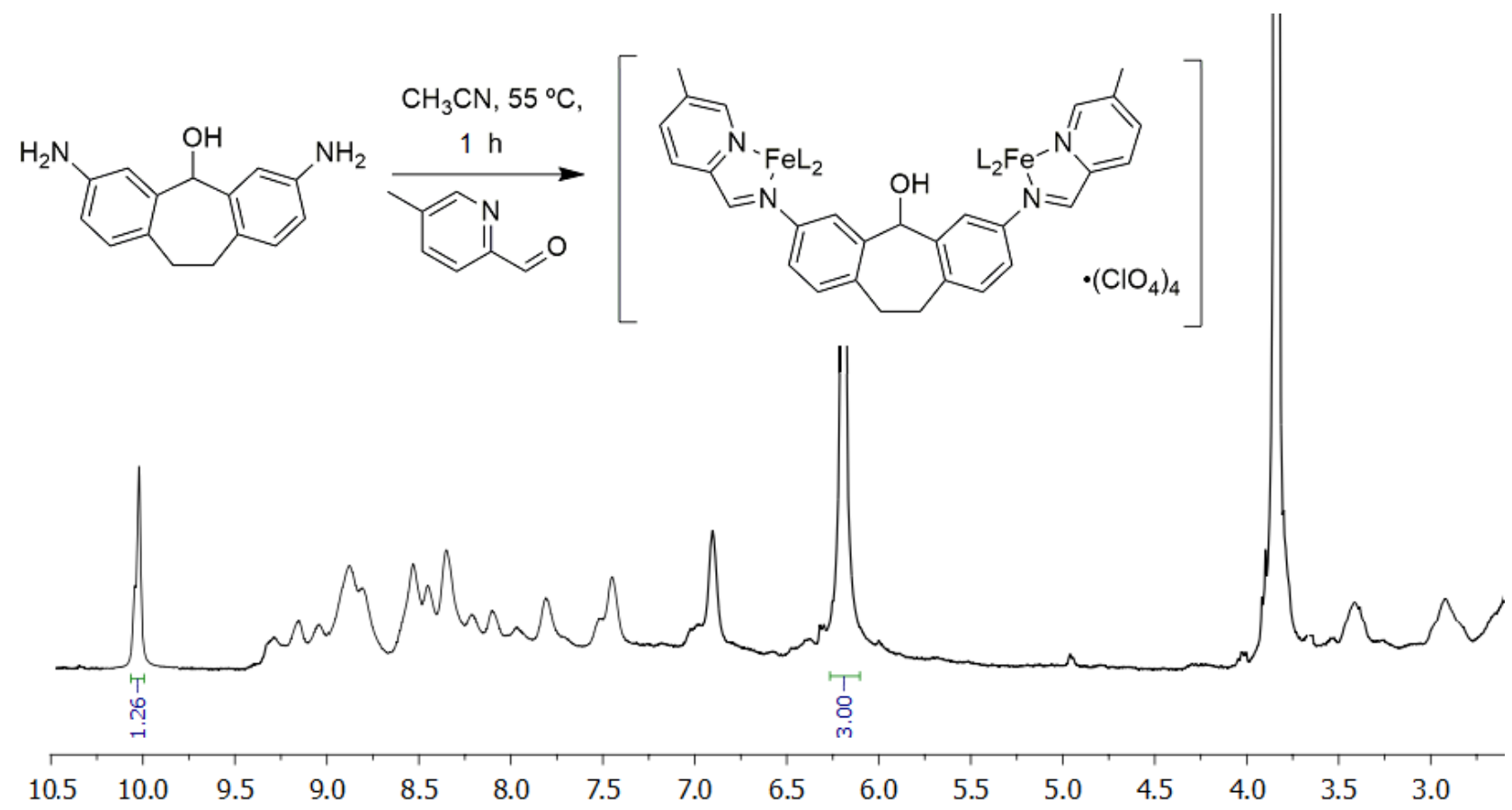

Figure S34. ${ }^{1} \mathrm{H}$ NMR spectra of products formed upon mixing suberone ligand A, methyl-formylpyridine 6, $\mathrm{Fe}\left(\mathrm{ClO}_{4}\right)_{2}$ and 1,3,5-trimethoxybenzene, and heating at $55^{\circ} \mathrm{C}$ for 1 hour $\left(\mathrm{CD}_{3} \mathrm{CN}, 400 \mathrm{MHz}, 298 \mathrm{~K}\right)$.

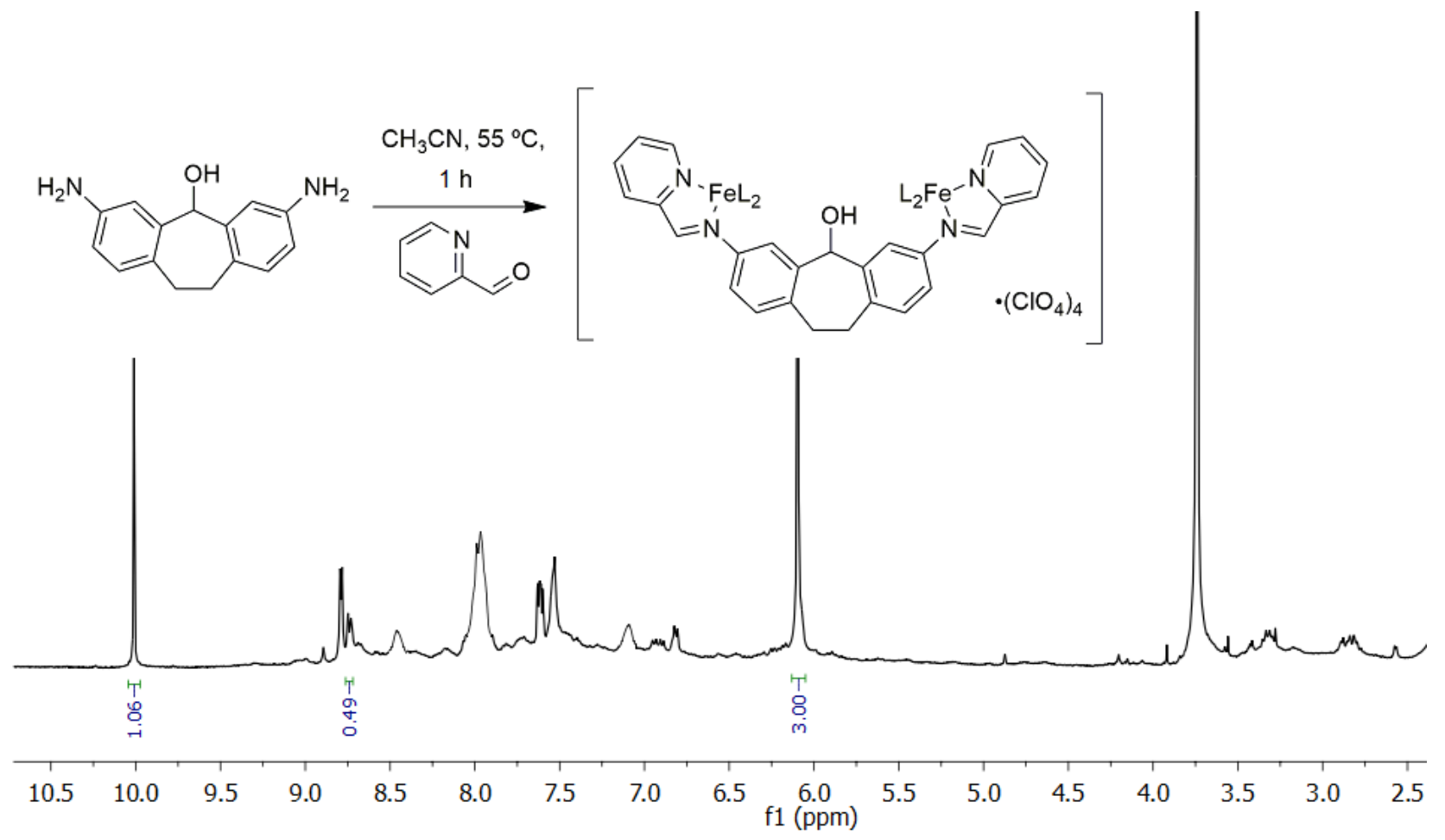

Figure S35. ${ }^{1} \mathrm{H}$ NMR spectra of products formed upon mixing suberol ligand $\mathbf{B}$, formylpyridine 4, $\mathrm{Fe}\left(\mathrm{ClO}_{4}\right)_{2}$ and 1,3,5-trimethoxybenzene, and heating at $55^{\circ} \mathrm{C}$ for 1 hour $\left(\mathrm{CD}_{3} \mathrm{CN}, 400 \mathrm{MHz}, 298 \mathrm{~K}\right)$. 


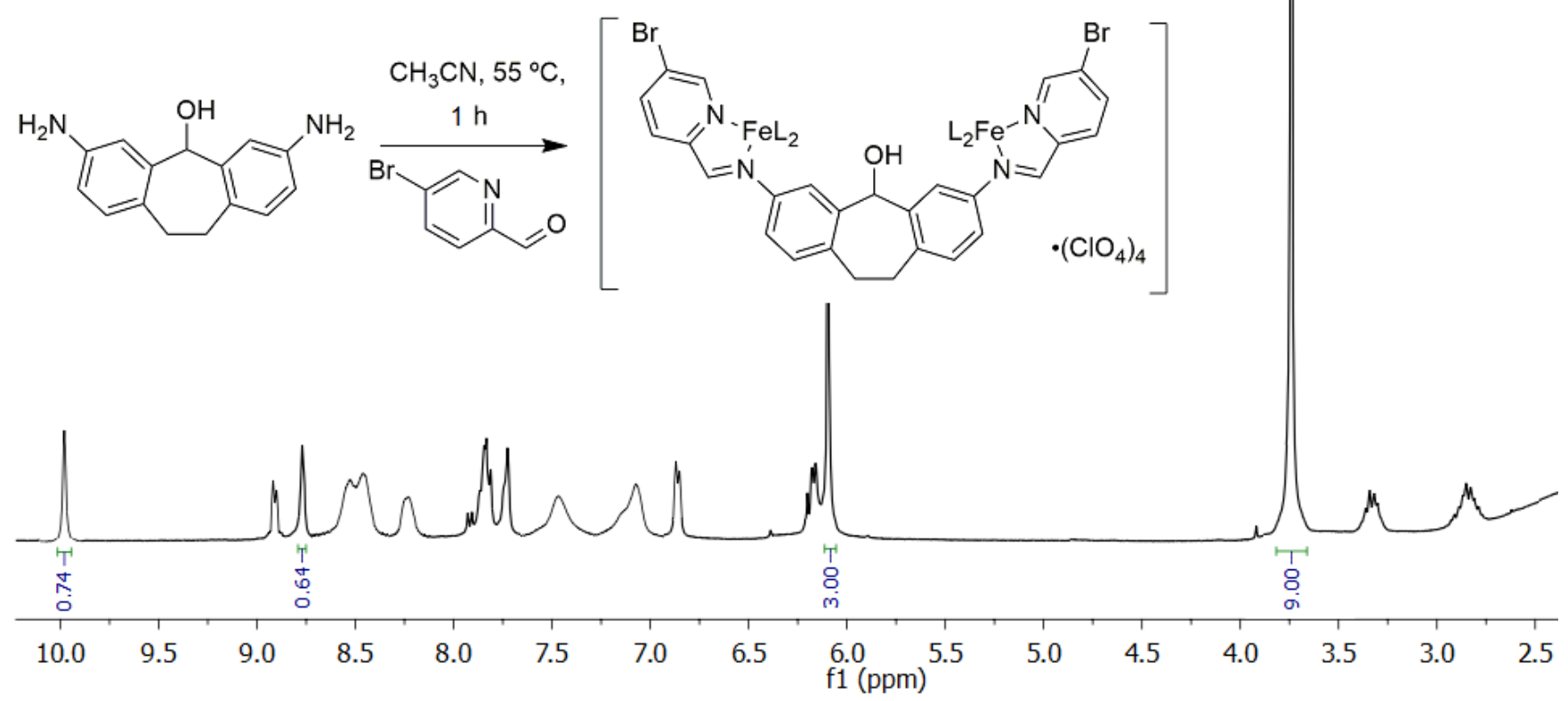

Figure S36. ${ }^{1} \mathrm{H}$ NMR spectra of products formed upon mixing suberol ligand $\mathbf{B}$, bromo-formylpyridine 5, $\mathrm{Fe}\left(\mathrm{ClO}_{4}\right)_{2}$ and 1,3,5-trimethoxybenzene, and heating at $55^{\circ} \mathrm{C}$ for 1 hour $\left(\mathrm{CD}_{3} \mathrm{CN}, 400 \mathrm{MHz}, 298 \mathrm{~K}\right)$.

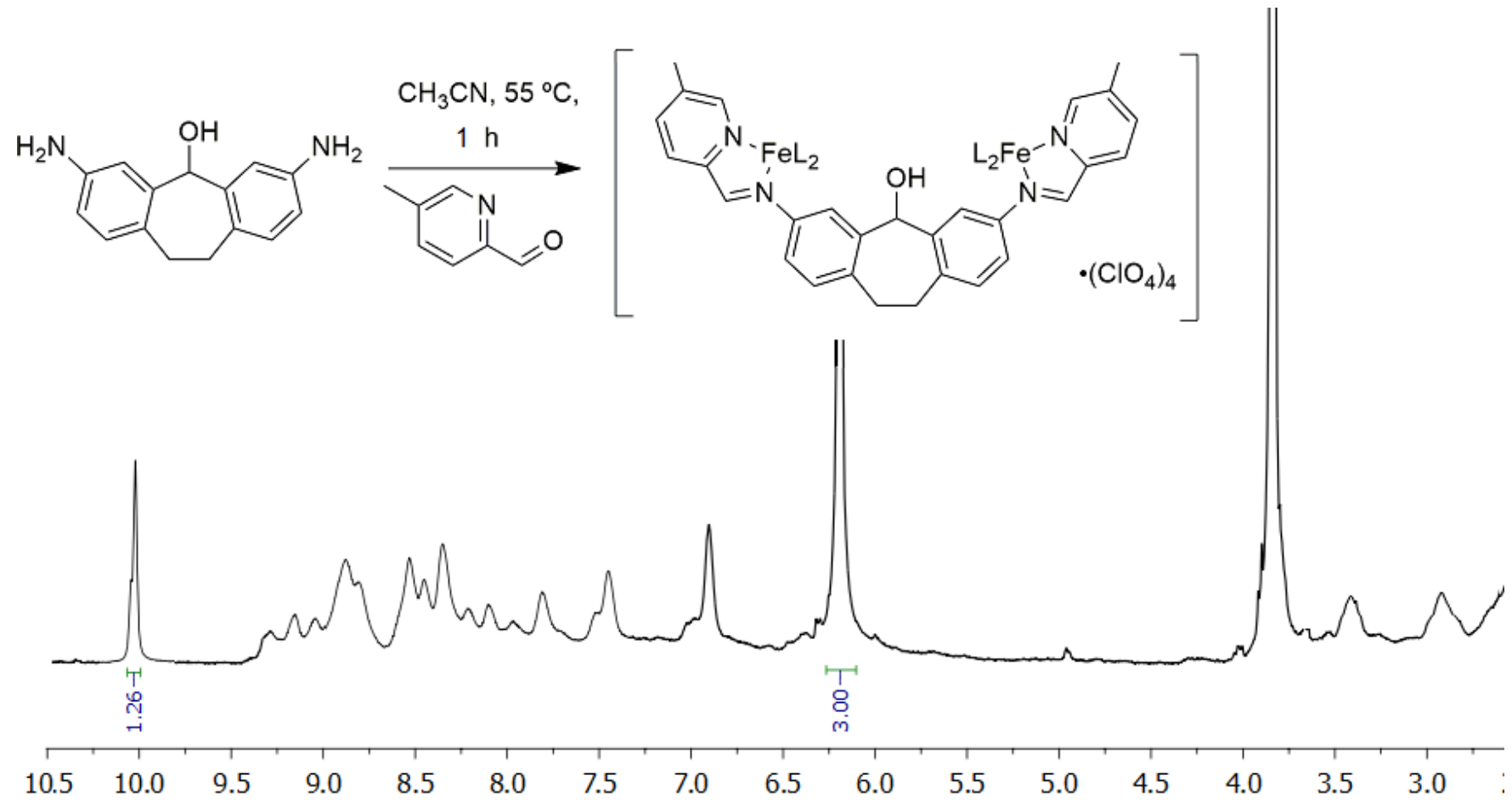

Figure S37. ${ }^{1} \mathrm{H}$ NMR spectra of products formed upon mixing suberol ligand $\mathbf{B}$, methyl-formylpyridine 6, $\mathrm{Fe}\left(\mathrm{ClO}_{4}\right)_{2}$ and 1,3,5-trimethoxybenzene, and heating at $55^{\circ} \mathrm{C}$ for 1 hour $\left(\mathrm{CD}_{3} \mathrm{CN}, 400 \mathrm{MHz}, 298 \mathrm{~K}\right)$. The $\% \mathbf{2} \cdot \mathrm{Me}_{6}$ cage formed at $1 \mathrm{~h}$ could not be quantified from these trials. 


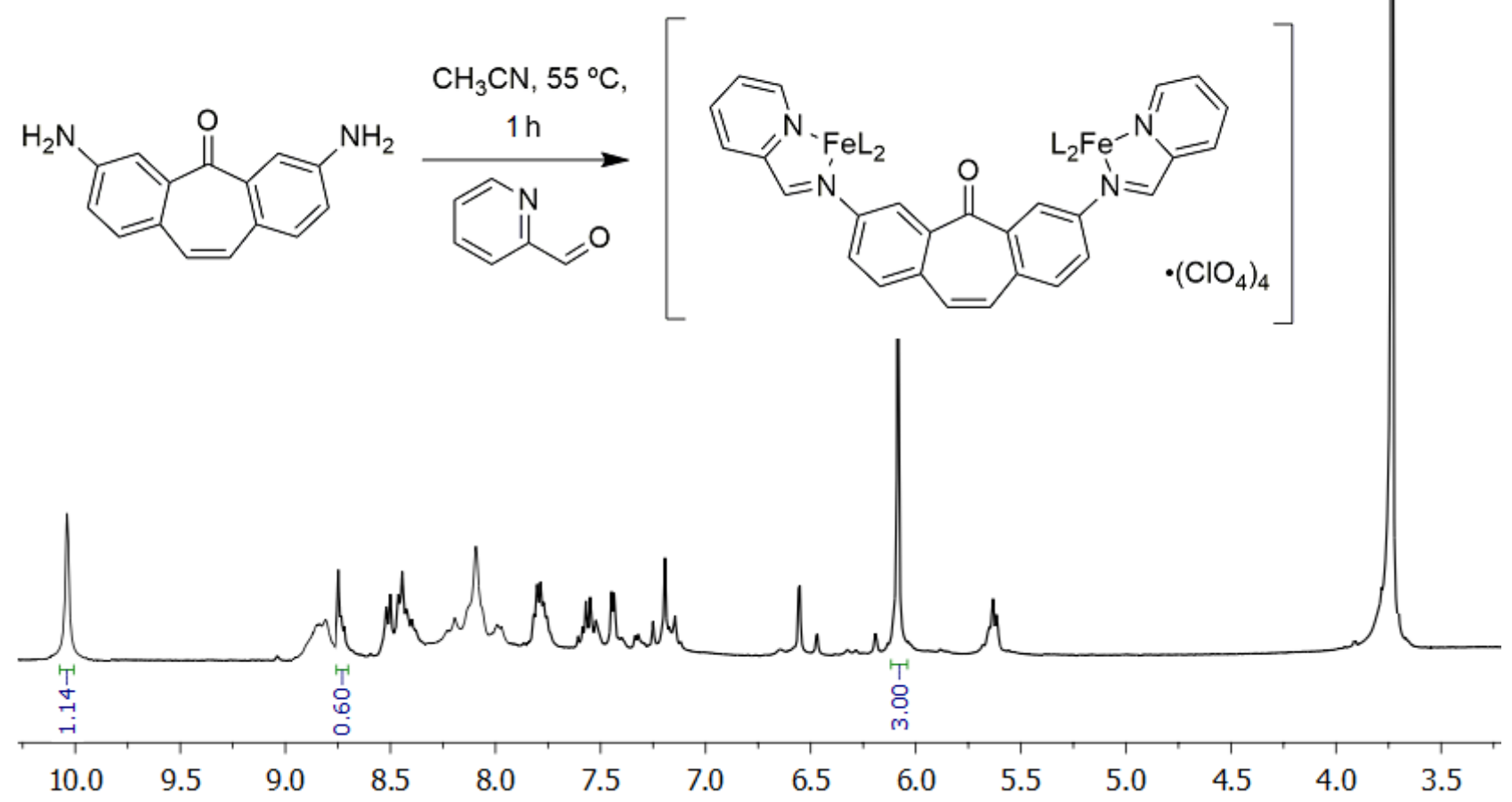

Figure S38. ${ }^{1} \mathrm{H}$ NMR spectra of products formed upon mixing suberenone ligand $\mathbf{C}$, formylpyridine $\mathbf{4}$, $\mathrm{Fe}\left(\mathrm{ClO}_{4}\right)_{2}$ and 1,3,5-trimethoxybenzene, and heating at $55^{\circ} \mathrm{C}$ for 1 hour $\left(\mathrm{CD}_{3} \mathrm{CN}, 400 \mathrm{MHz}, 298 \mathrm{~K}\right)$.

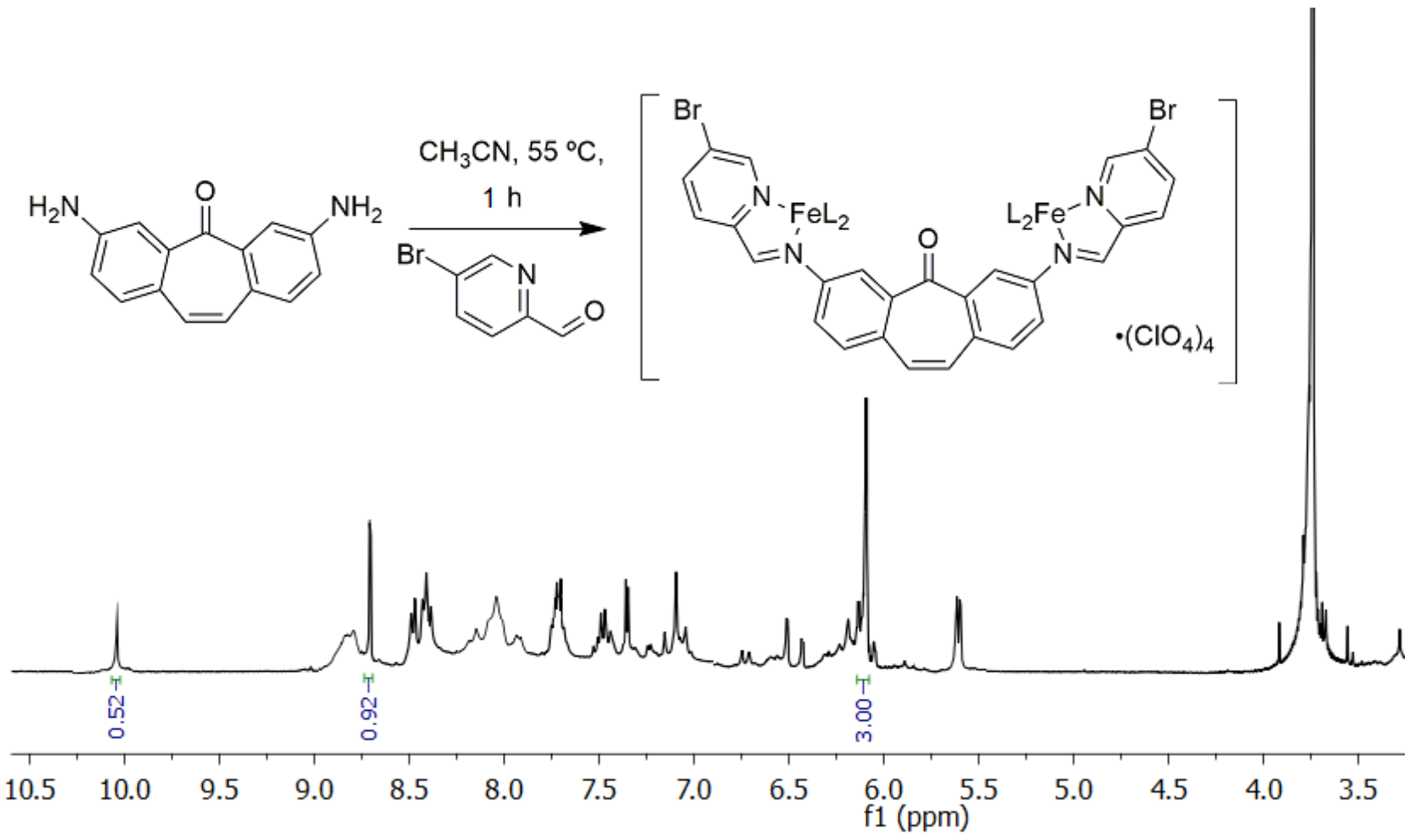

Figure S39. ${ }^{1} \mathrm{H}$ NMR spectra of products formed upon mixing suberenone ligand C, bromoformylpyridine 5, $\mathrm{Fe}\left(\mathrm{ClO}_{4}\right)_{2}$ and 1,3,5-trimethoxybenzene, and heating at $55{ }^{\circ} \mathrm{C}$ for 1 hour $\left(\mathrm{CD}_{3} \mathrm{CN}, 400\right.$ $\mathrm{MHz}, 298 \mathrm{~K})$. 


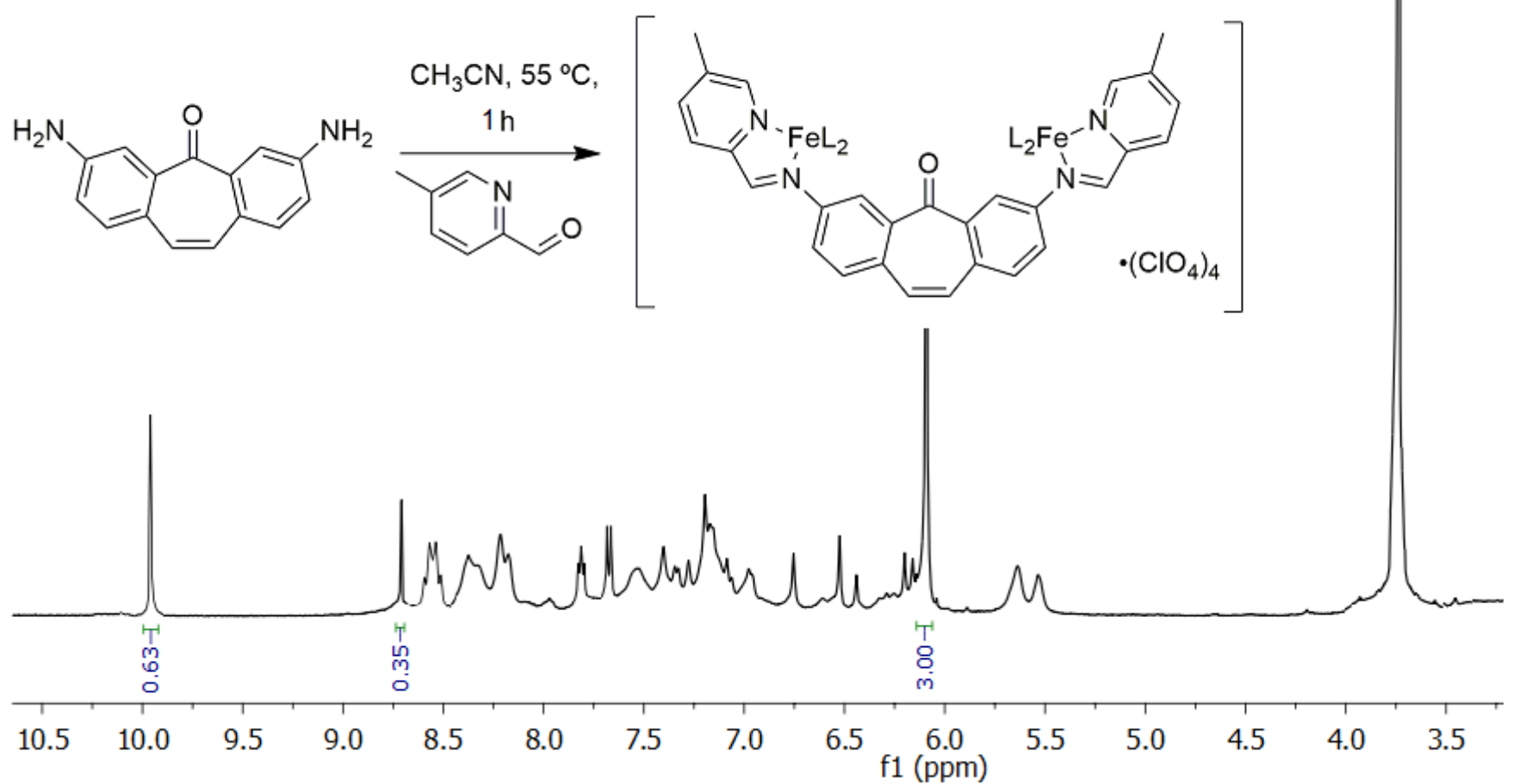

Figure S40. ${ }^{1} \mathrm{H}$ NMR spectra of products formed upon mixing suberenone ligand C, methylformylpyridine 6, $\mathrm{Fe}\left(\mathrm{ClO}_{4}\right)_{2}$ and 1,3,5-trimethoxybenzene, and heating at $55{ }^{\circ} \mathrm{C}$ for 1 hour $\left(\mathrm{CD}_{3} \mathrm{CN}, 400\right.$ $\mathrm{MHz}, 298 \mathrm{~K})$. 


\section{Ligand Self-Sorting Experiments}

\section{3a. Fully Equilibrated Ligand Self-Sorting Experiments}
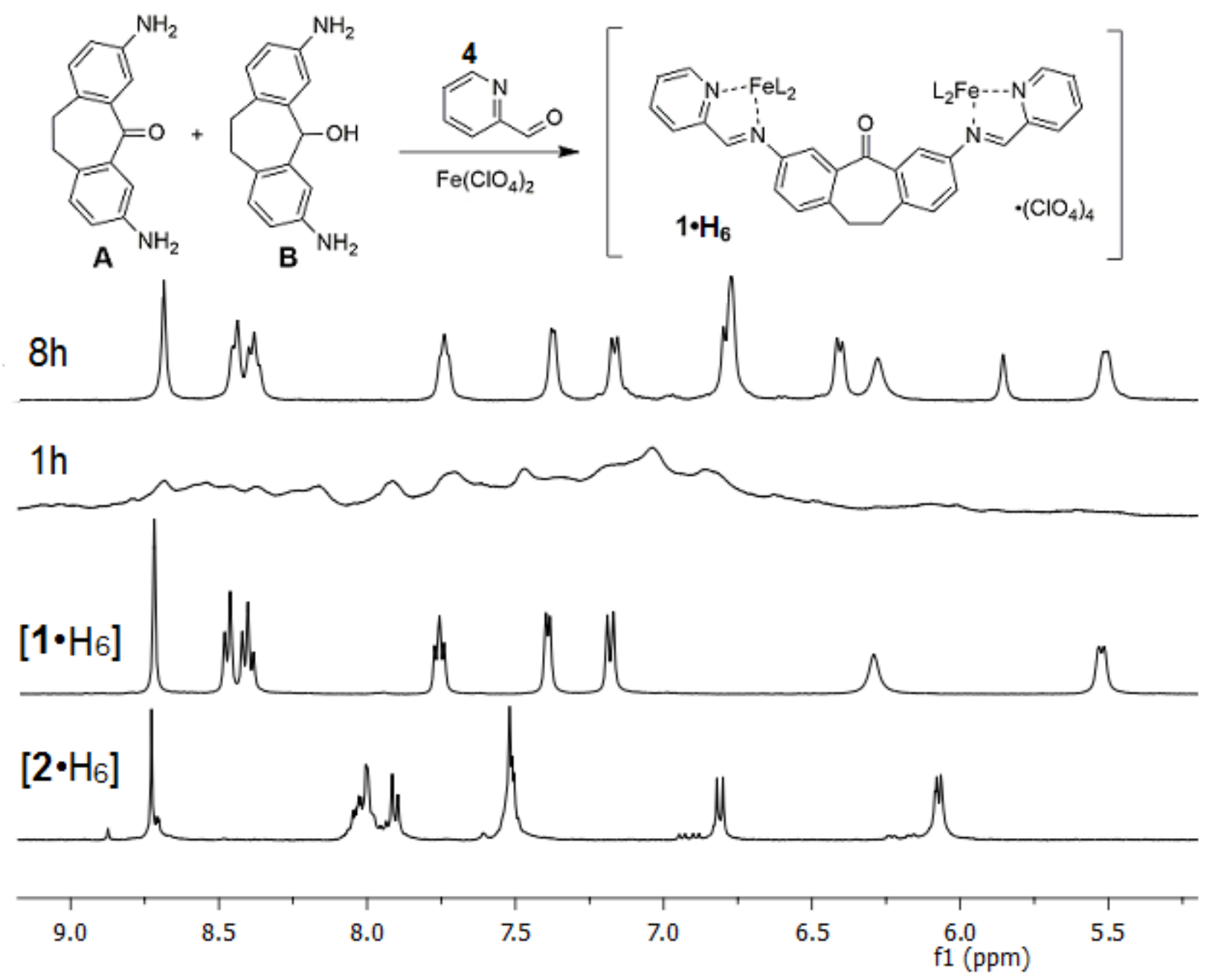

Figure S41. ${ }^{1} \mathrm{H}$ NMR spectra of products formed upon mixing suberone ligand $\mathbf{A}$, suberol ligand $\mathbf{B}$, and formylpyridine 4 with $\mathrm{Fe}\left(\mathrm{ClO}_{4}\right)_{2}$ in an NMR tube and heating at $55{ }^{\circ} \mathrm{C}$ over time. The initial ligand concentrations were $39 \mathrm{mM}$ each. $\left(\mathrm{CD}_{3} \mathrm{CN}, 400 \mathrm{MHz}, 298 \mathrm{~K}\right)$. 


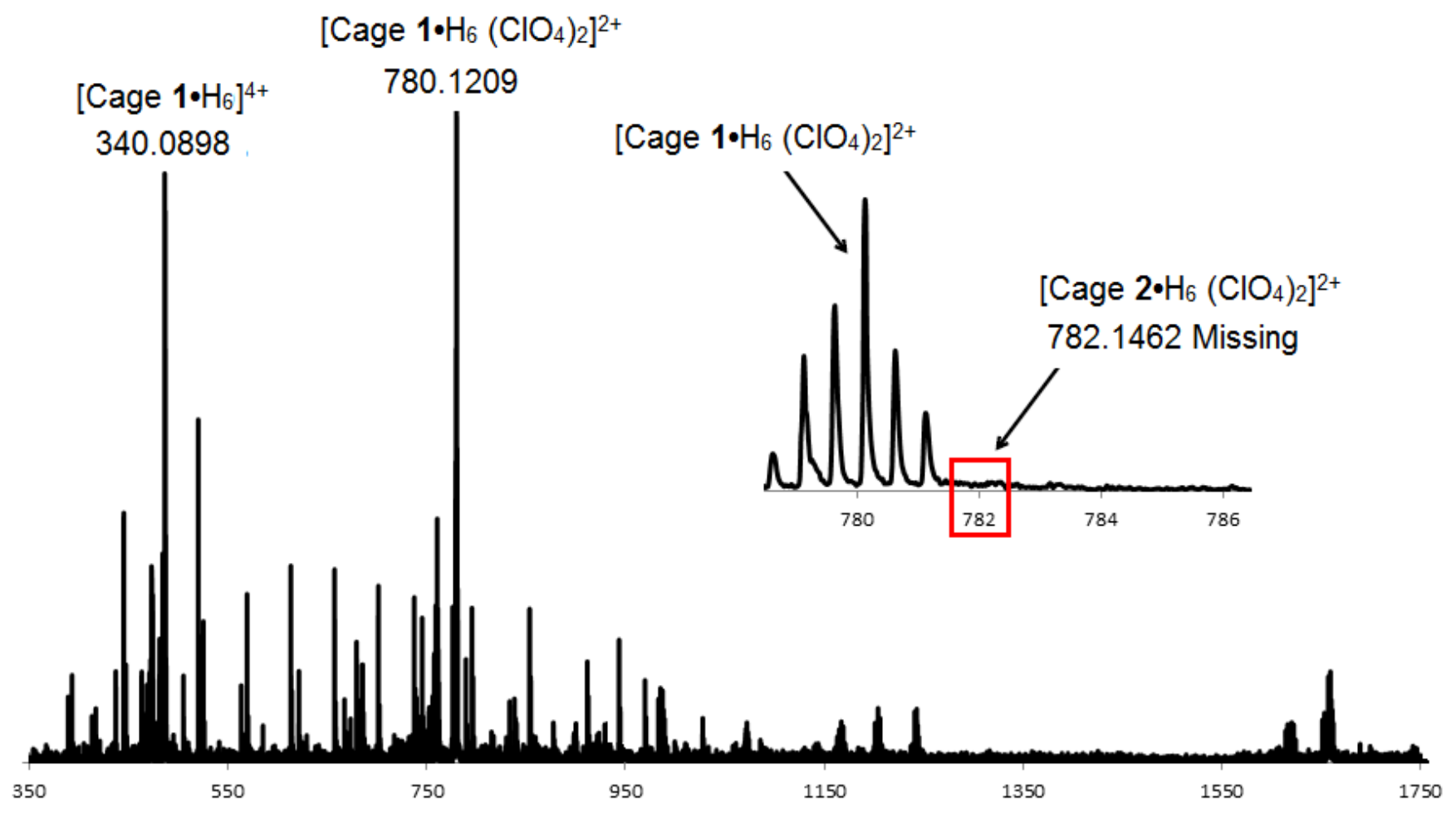

Figure S42. Full ESI-MS of products obtained after suberone dianiline $\mathbf{A}$ and suberol dianiline $\mathbf{B}$ were mixed with $\mathrm{Fe}\left(\mathrm{ClO}_{4}\right)_{2}$ and formylpyridine 4 with $8 \mathrm{~h}$ heat at $55^{\circ} \mathrm{C}$. No peaks are visible for cage $2 \cdot \mathrm{H}_{6}$ and the spectrum is dominated by peaks for cage $1 \cdot \mathrm{H}_{6}$. 

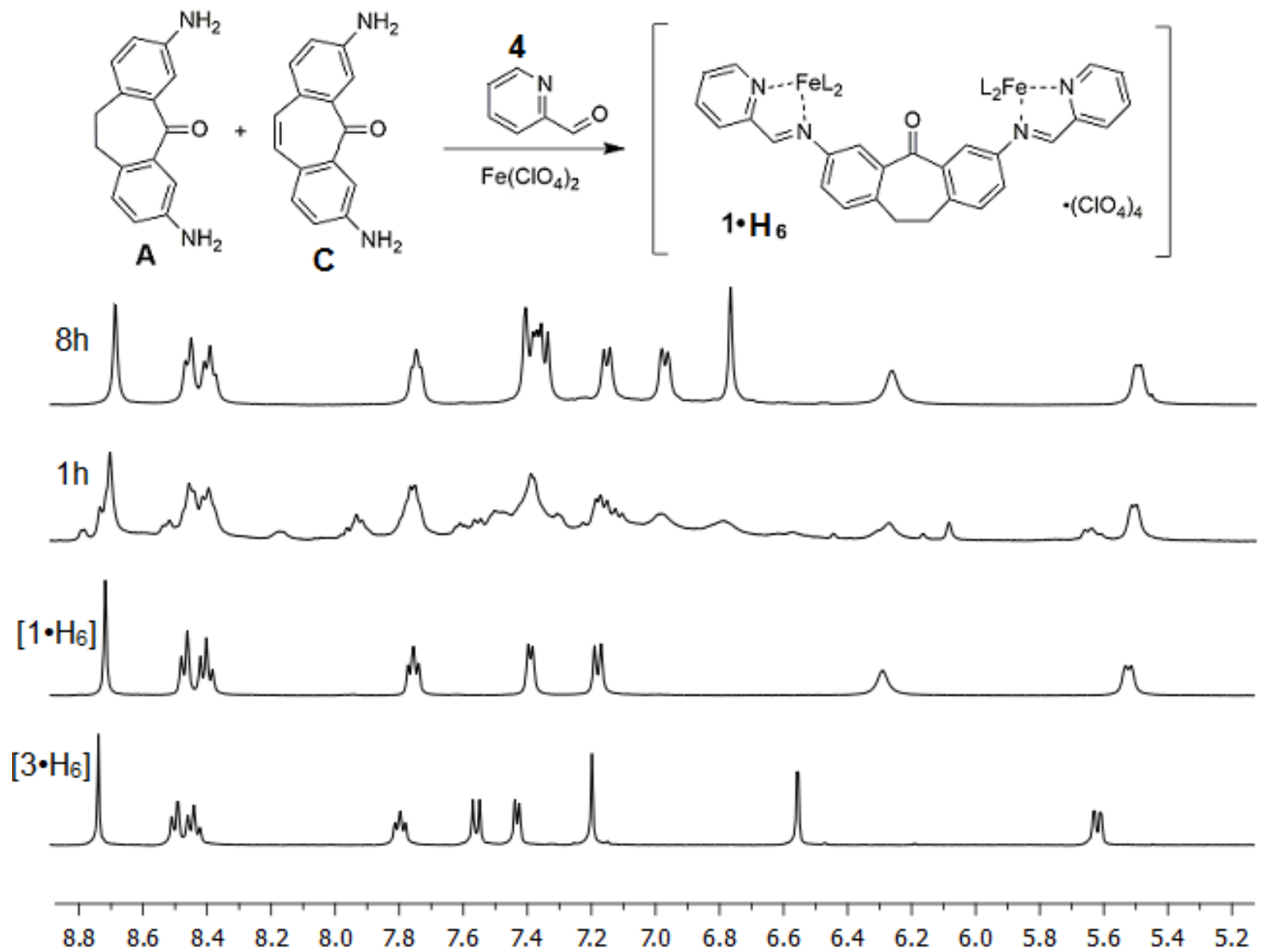

Figure S43. ${ }^{1} \mathrm{H}$ NMR spectra of products formed upon mixing suberone ligand $\mathbf{A}$, suberol ligand $\mathbf{C}$, and formylpyridine 4 with $\mathrm{Fe}\left(\mathrm{ClO}_{4}\right)_{2}$ in an NMR tube and heating at $55{ }^{\circ} \mathrm{C}$ over time. The initial ligand concentrations were $39 \mathrm{mM}$ each. $\left(\mathrm{CD}_{3} \mathrm{CN}, 400 \mathrm{MHz}, 298 \mathrm{~K}\right)$. 


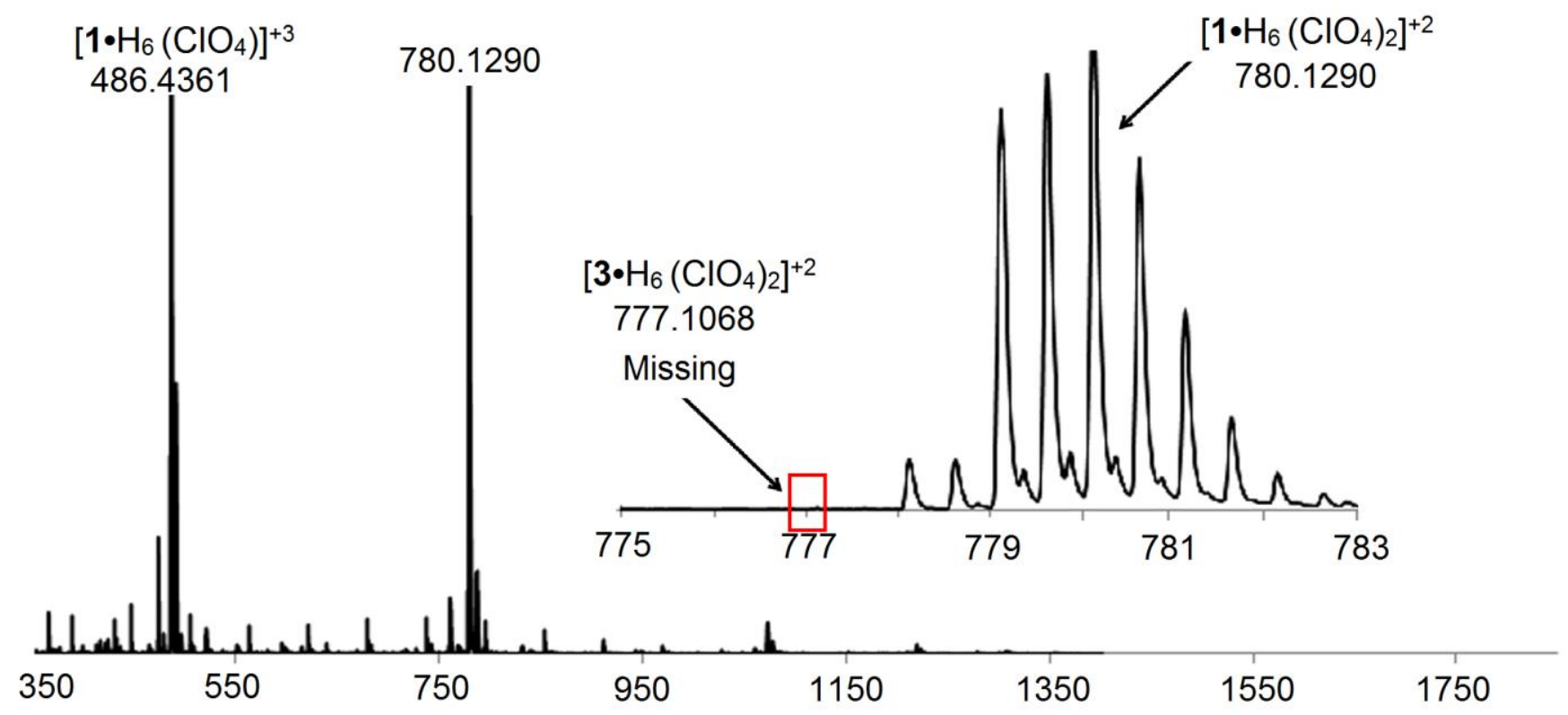

Figure S44. Full ESI-MS of products obtained after suberone dianiline $\mathbf{A}$ and suberol dianiline $\mathbf{C}$ were mixed with $\mathrm{Fe}\left(\mathrm{ClO}_{4}\right)_{2}$ and formylpyridine 4 with $8 \mathrm{~h}$ heat at $55^{\circ} \mathrm{C}$. No peaks are visible for cage $\mathbf{3} \cdot \mathrm{H}_{6}$ and the spectrum is dominated by peaks for cage $1 \cdot \mathrm{H}_{6}$. 


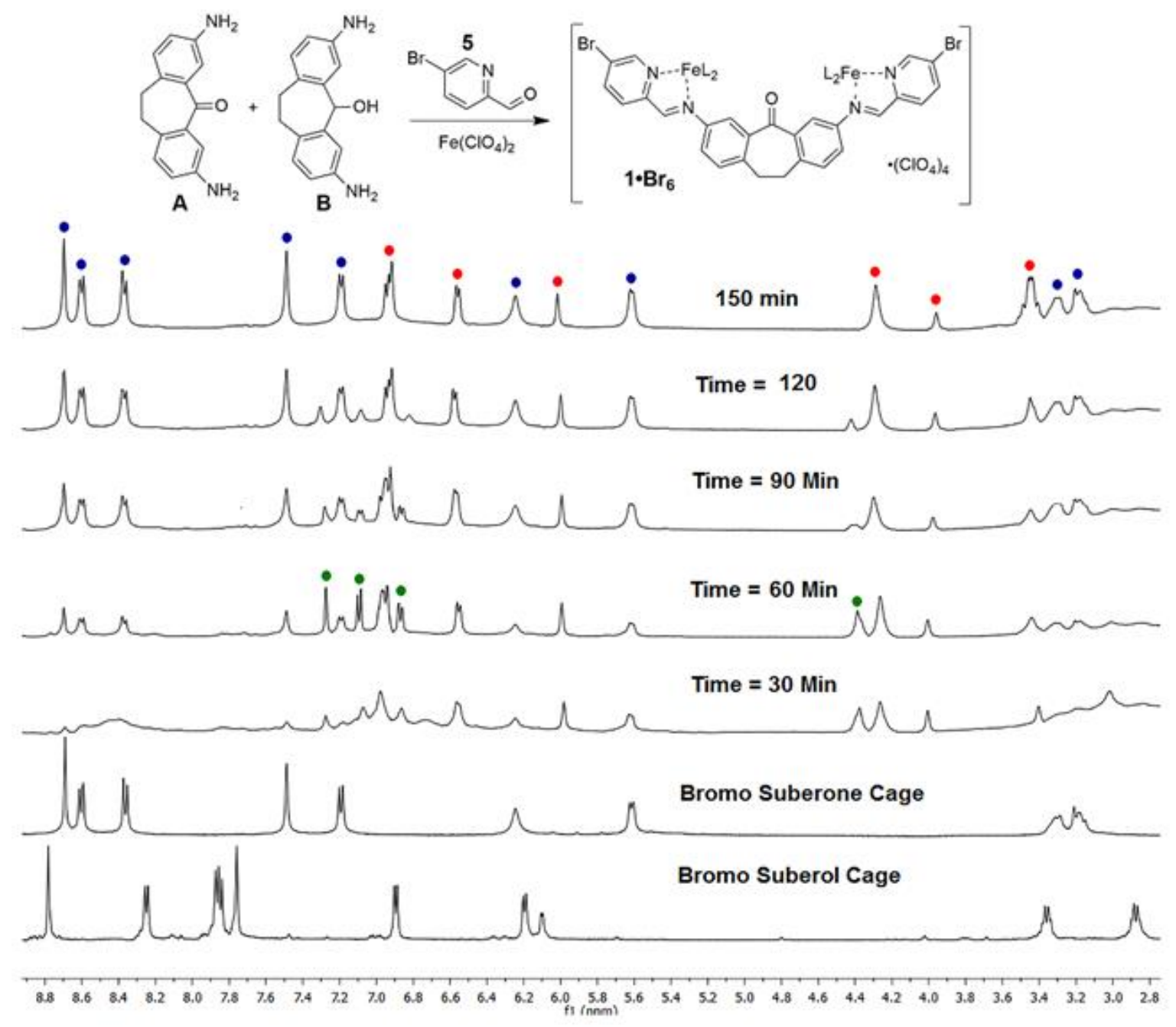

Figure S45. ${ }^{1} \mathrm{H}$ NMR spectra of products formed upon mixing suberone ligand A (green), suberol ligand B (red), and bromo-formylpyridine 5 with $\mathrm{Fe}\left(\mathrm{ClO}_{4}\right)_{2}$ in an NMR tube and heating at $55{ }^{\circ} \mathrm{C}$ over time. The initial ligand concentrations were $13 \mathrm{mM}$ each. $\left(\mathrm{CD}_{3} \mathrm{CN}, 400 \mathrm{MHz}, 298 \mathrm{~K}\right)$. 

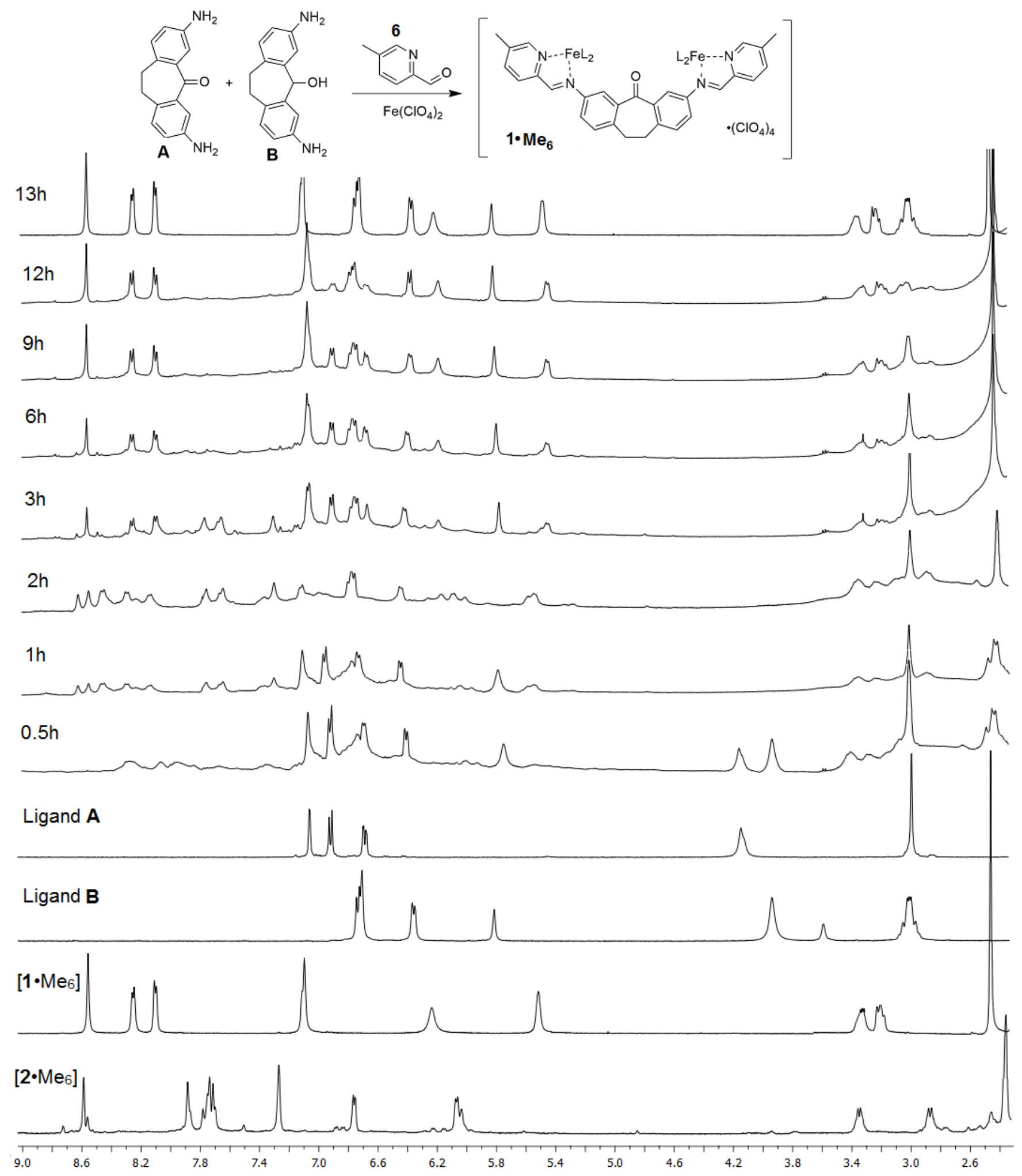

Figure S46. ${ }^{1} \mathrm{H}$ NMR spectra of products formed upon mixing suberone ligand $\mathbf{A}$, suberol ligand $\mathbf{B}$, and methyl-formylpyridine 6 with $\mathrm{Fe}\left(\mathrm{ClO}_{4}\right)_{2}$ in an NMR tube and heating at $55{ }^{\circ} \mathrm{C}$ over time. The initial ligand concentrations were $13 \mathrm{mM}$ each. $\left(\mathrm{CD}_{3} \mathrm{CN}, 400 \mathrm{MHz}, 298 \mathrm{~K}\right)$. 

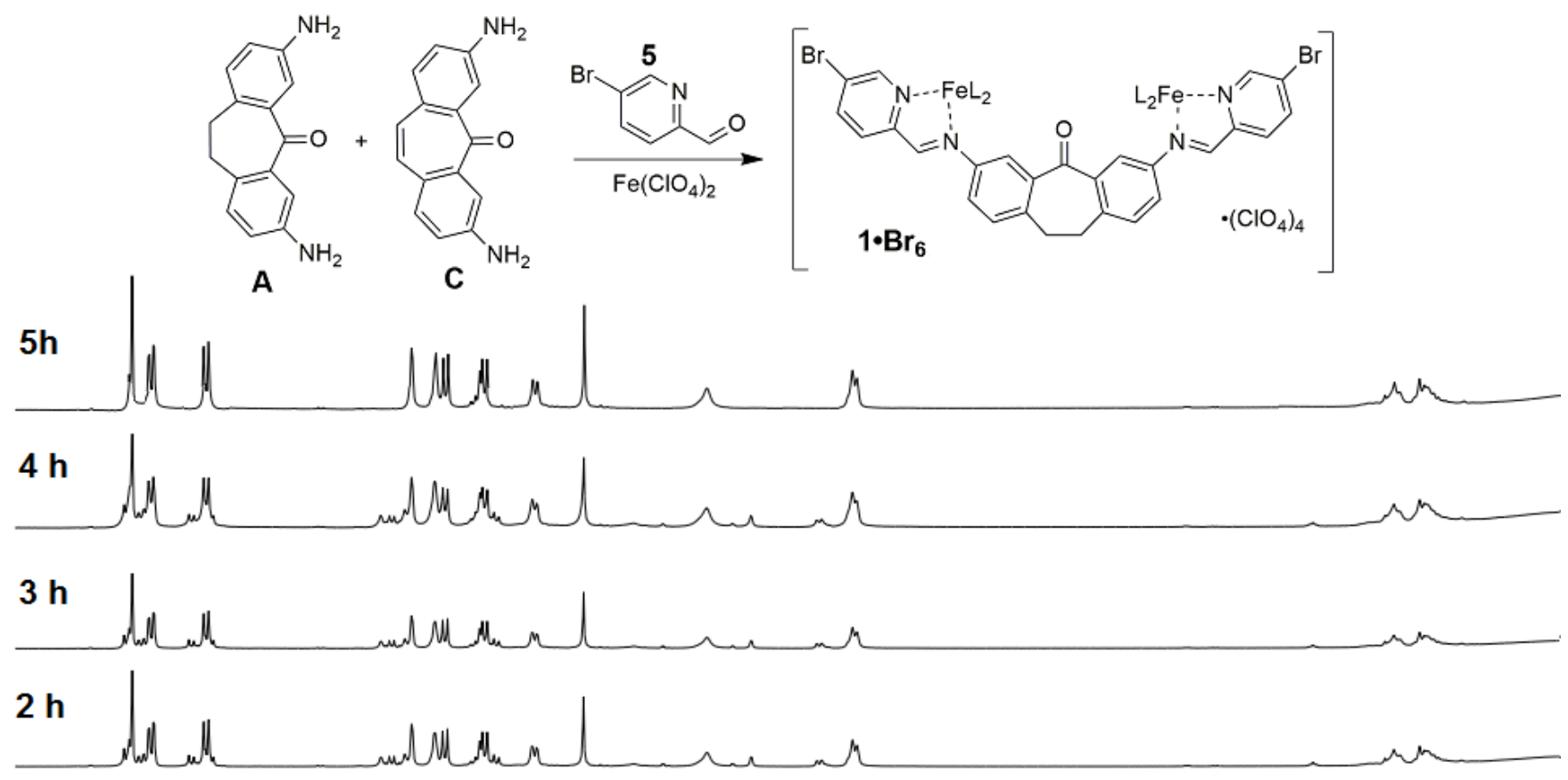

\section{$1.5 \mathrm{~h}$}

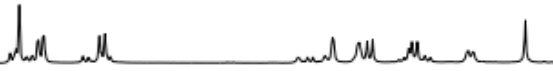

$1 \mathrm{~h}$

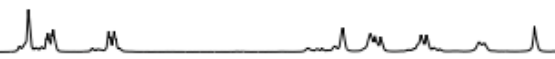

\section{$0.5 \mathrm{~h}$}
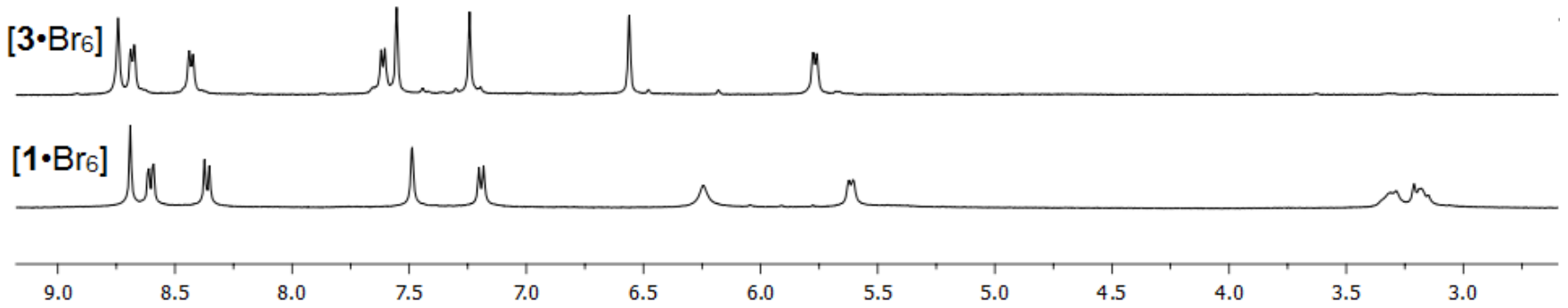

Figure S47. ${ }^{1} \mathrm{H}$ NMR spectra of products formed upon mixing suberone ligand $\mathbf{A}$, suberenone ligand $\mathbf{C}$, and bromo-formylpyridine 5 with $\mathrm{Fe}\left(\mathrm{ClO}_{4}\right)_{2}$ in an $\mathrm{NMR}$ tube and heating at $55{ }^{\circ} \mathrm{C}$ over time. The initial ligand concentrations were $39 \mathrm{mM}$ each. $\left(\mathrm{CD}_{3} \mathrm{CN}, 400 \mathrm{MHz}, 298 \mathrm{~K}\right)$. 


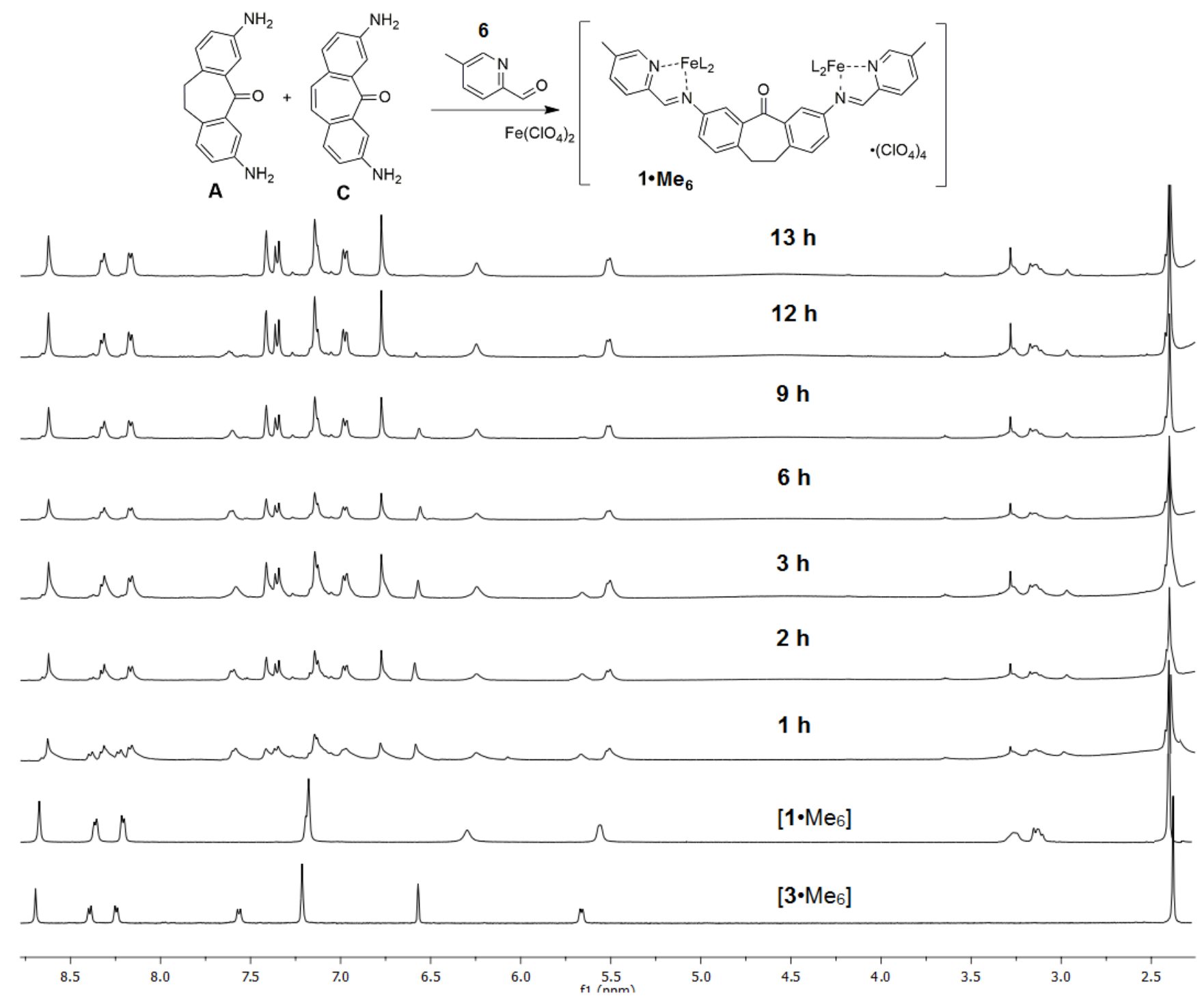

Figure S48. ${ }^{1} \mathrm{H}$ NMR spectra of products formed upon mixing suberone ligand $\mathbf{A}$, suberenone ligand $\mathbf{C}$, and methyl-formylpyridine 6 with $\mathrm{Fe}\left(\mathrm{ClO}_{4}\right)_{2}$ in an NMR tube and heating at $55{ }^{\circ} \mathrm{C}$ over time. The initial ligand concentrations were $39 \mathrm{mM}$ each. ( $\left.\mathrm{CD}_{3} \mathrm{CN}, 400 \mathrm{MHz}, 298 \mathrm{~K}\right)$. 


\section{3b Standardized 2 h Ligand Self-Sorting Experiments}

\begin{tabular}{ccccccc} 
Ligand & Pyridine & $\begin{array}{c}\text { Sorting } \\
\text { Completion }\end{array}$ & $\begin{array}{c}\text { \% Favored } \\
\text { Cage at 2 h }\end{array}$ & $\begin{array}{c}\text { \% Less } \\
\text { Favored Cage } \\
\text { at 2 h }\end{array}$ & $\begin{array}{c}\text { \% Unreacted } \\
\text { pyridine at } \mathbf{~ h ~}\end{array}$ & $\begin{array}{c}\text { Intermediates } \\
\text { at } \mathbf{2 h}\end{array}$ \\
\hline $\mathbf{A}+\mathbf{B}$ & $\mathbf{4}$ & $8 \mathrm{~h}$ & $30.7 \pm 0.5 \mathbf{1} \cdot \mathrm{H}_{6}$ & $4.5 \pm 0.5 \mathbf{2} \cdot \mathrm{H}_{6}$ & $22 \pm 0.5$ & 42 \\
$\mathbf{A}+\mathbf{C}$ & $\mathbf{4}$ & $8 \mathrm{~h}$ & $29.2 \pm 0.5 \mathbf{1} \cdot \mathrm{H}_{6}$ & $6.4 \pm 0.5 \mathbf{3} \cdot \mathrm{H}_{6}$ & $5.1 \pm 0.5$ & 61 \\
$\mathbf{A}+\mathbf{B}$ & $\mathbf{5}$ & $3 \mathrm{~h}$ & $63.1 \pm 0.5 \mathbf{1} \cdot \mathrm{Br}_{6}$ & $0 \mathbf{2 \cdot} \cdot \mathrm{Br}_{6}$ & $12.1 \pm 0.6$ & 24 \\
$\mathbf{A}+\mathbf{C}$ & $\mathbf{5}$ & $5 \mathrm{~h}$ & $34.6 \pm 0.5 \mathbf{1 \cdot} \cdot \mathrm{Br}_{6}$ & $4.1 \pm 0.5 \mathbf{3} \cdot \mathrm{Br}_{6}$ & $10.2 \pm 0.5$ & 52 \\
$\mathbf{A}+\mathbf{B}$ & $\mathbf{6}$ & $13 \mathrm{~h}$ & $16.9 \pm 0.5 \mathbf{1 \cdot} \cdot \mathrm{Me}_{6}$ & $7.4 \pm 0.5 \mathbf{2} \cdot \mathrm{Me}_{6}$ & $18 \pm 0.6$ & 58 \\
$\mathbf{A}+\mathbf{C}$ & $\mathbf{6}$ & $13 \mathrm{~h}$ & $27.1 \pm 0.5 \mathbf{1 \cdot} \cdot \mathrm{Me}_{6}$ & $9.6 \pm 0.5 \mathbf{3} \cdot \mathrm{Me}_{6}$ & $14.2 \pm 0.5$ & 49
\end{tabular}

Figure S49. Results of Timed and standardized self-sorting experiments

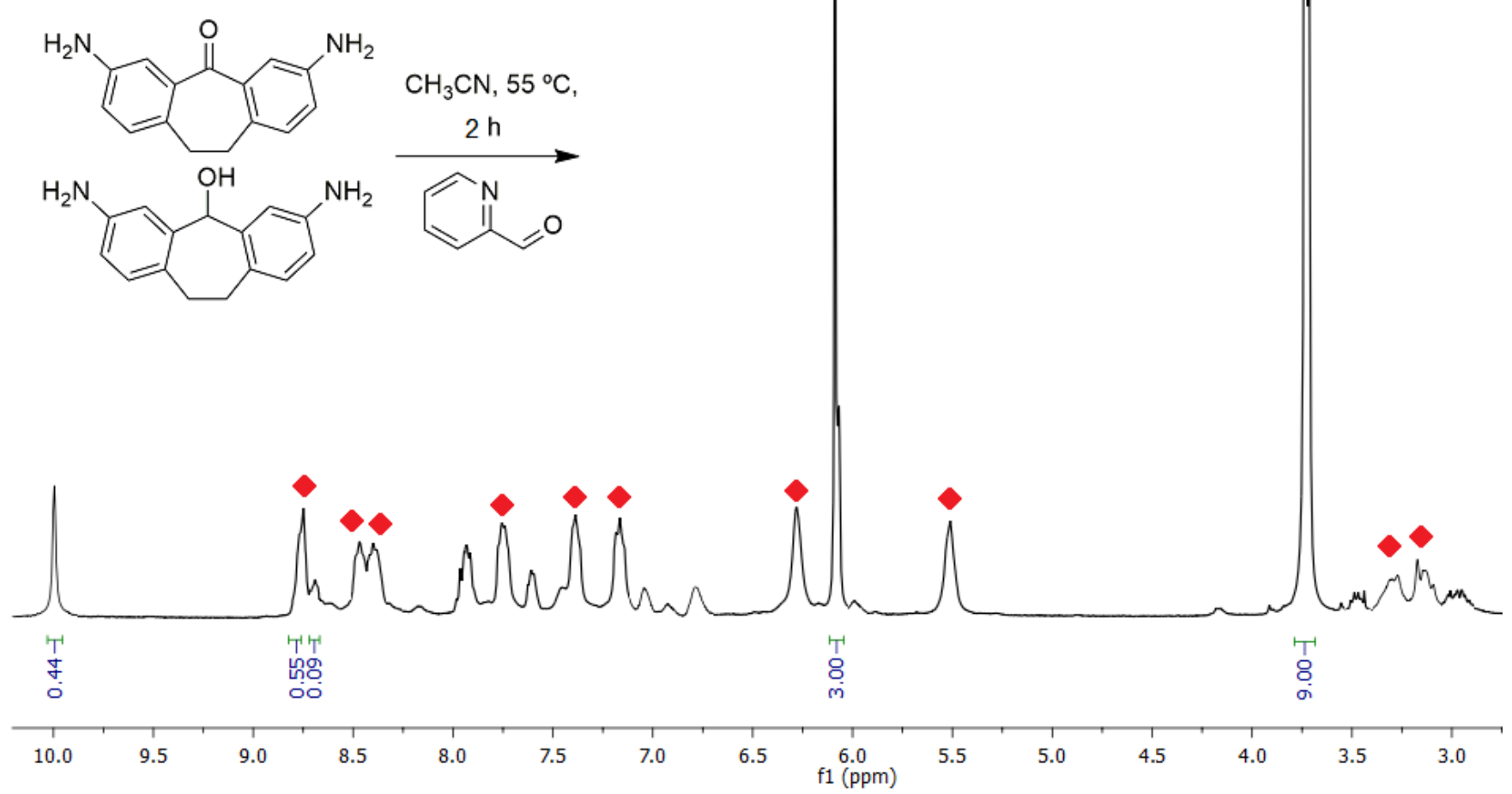

Figure S50. ${ }^{1} \mathrm{H}$ NMR spectra of products formed upon mixing suberone ligand $\mathbf{A}$, suberol ligand $\mathbf{B}$, and formylpyridine 4, with $\mathrm{Fe}\left(\mathrm{ClO}_{4}\right)_{2}$ and 1 equivalent 1,3,5-trimethyoxybenzene standard in an NMR tube with heating at $55^{\circ} \mathrm{C}$ over 2 hours $\left(\mathrm{CD}_{3} \mathrm{CN}, 400 \mathrm{MHz}, 298 \mathrm{~K}\right) \cdot \mathbf{1} \cdot \mathrm{H}_{6}$ peaks are marked with red dots. 


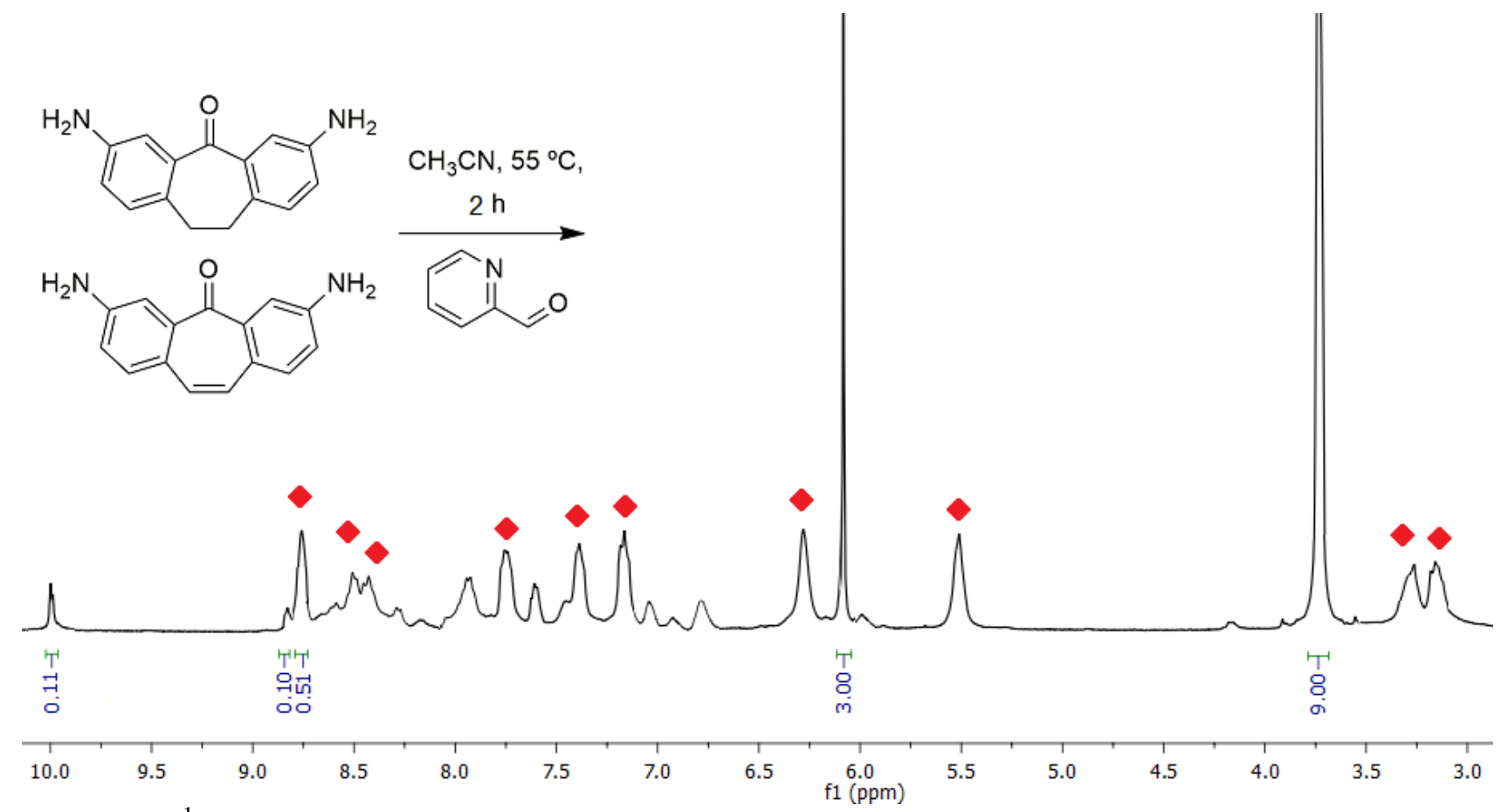

Figure S51. ${ }^{1} \mathrm{H}$ NMR spectra of products formed upon mixing suberone ligand $\mathbf{A}$, suberenone ligand $\mathbf{C}$, and formylpyridine 4, with $\mathrm{Fe}\left(\mathrm{ClO}_{4}\right)_{2}$ and 1 equivalent 1,3,5-trimethyoxybenzene standard in an NMR tube with heating at $55^{\circ} \mathrm{C}$ over 2 hours $\left(\mathrm{CD}_{3} \mathrm{CN}, 400 \mathrm{MHz}, 298 \mathrm{~K}\right) \cdot \mathbf{1} \cdot \mathrm{H}_{6}$ peaks are marked with red dots.

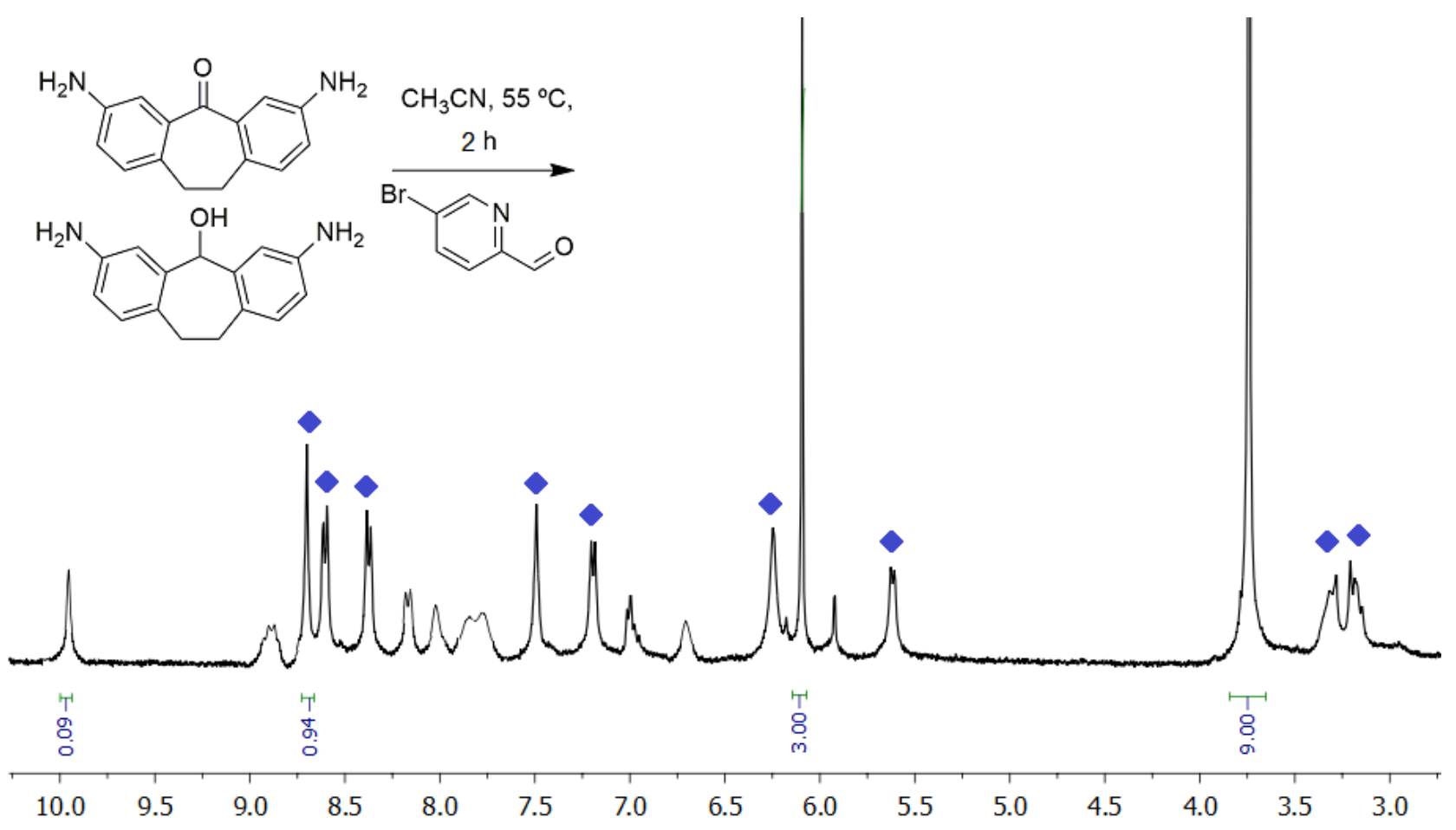

Figure S52. ${ }^{1} \mathrm{H}$ NMR spectra of products formed upon mixing suberone ligand $\mathbf{A}$, suberol ligand $\mathbf{B}$, and bromo-formylpyridine $\mathbf{5}$, with $\mathrm{Fe}\left(\mathrm{ClO}_{4}\right)_{2}$ and 1 equivalent 1,3,5-trimethyoxybenzene standard in an NMR tube with heating at $55{ }^{\circ} \mathrm{C}$ over 2 hours $\left(\mathrm{CD}_{3} \mathrm{CN}, 400 \mathrm{MHz}, 298 \mathrm{~K}\right) .1 \cdot \mathrm{Br}_{6}$ peaks are marked in blue. 


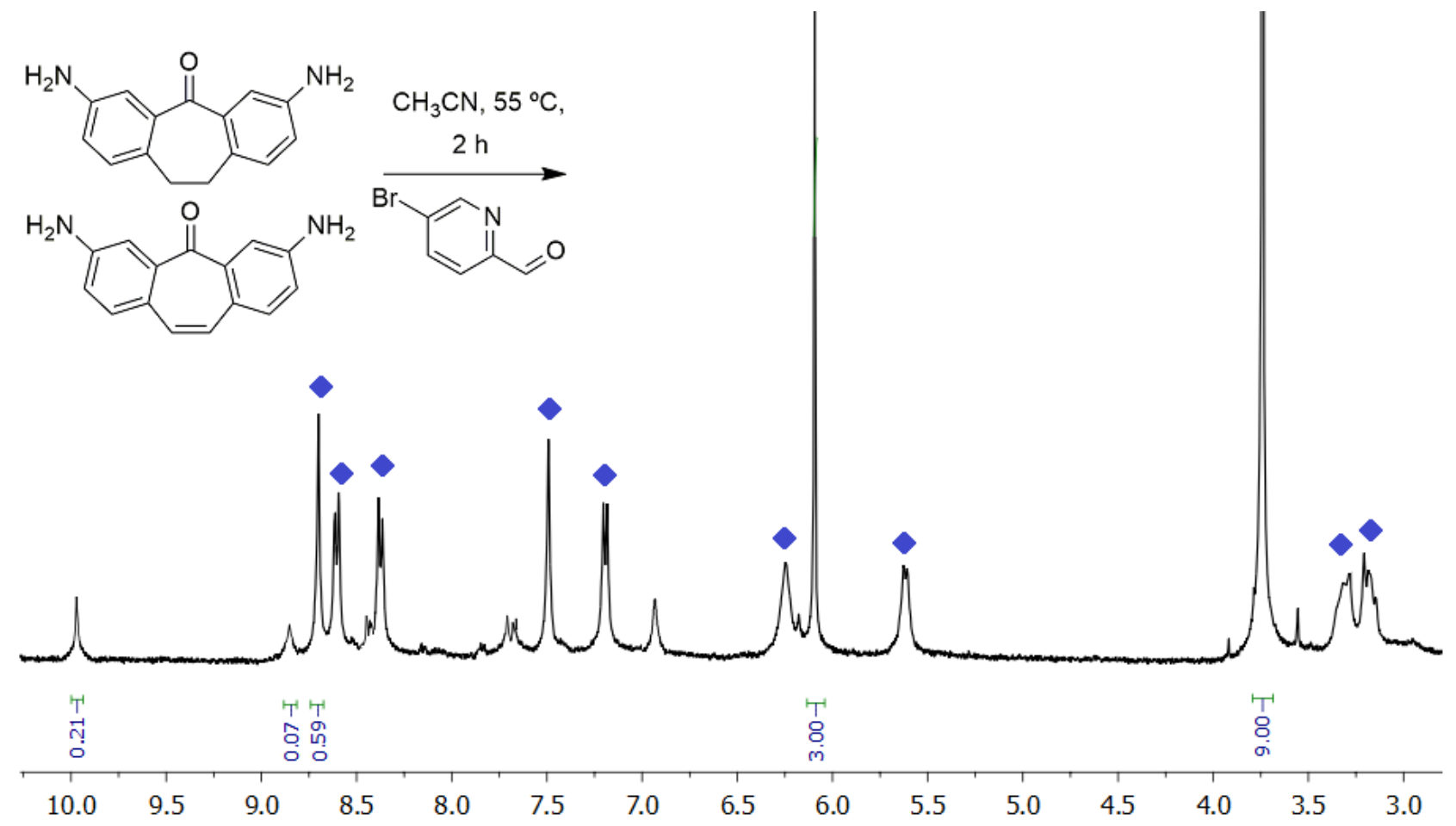

Figure S53. ${ }^{1} \mathrm{H}$ NMR spectra of products formed upon mixing suberone ligand $\mathbf{A}$, suberenone ligand $\mathbf{C}$, and bromo-formylpyridine 5, with $\mathrm{Fe}\left(\mathrm{ClO}_{4}\right)_{2}$ and 1 equivalent 1,3,5-trimethyoxybenzene standard in an NMR tube with heating at $55^{\circ} \mathrm{C}$ over 2 hours $\left(\mathrm{CD}_{3} \mathrm{CN}, 400 \mathrm{MHz}, 298 \mathrm{~K}\right) .1 \cdot \mathrm{Br}_{6}$ peaks are marked in blue.

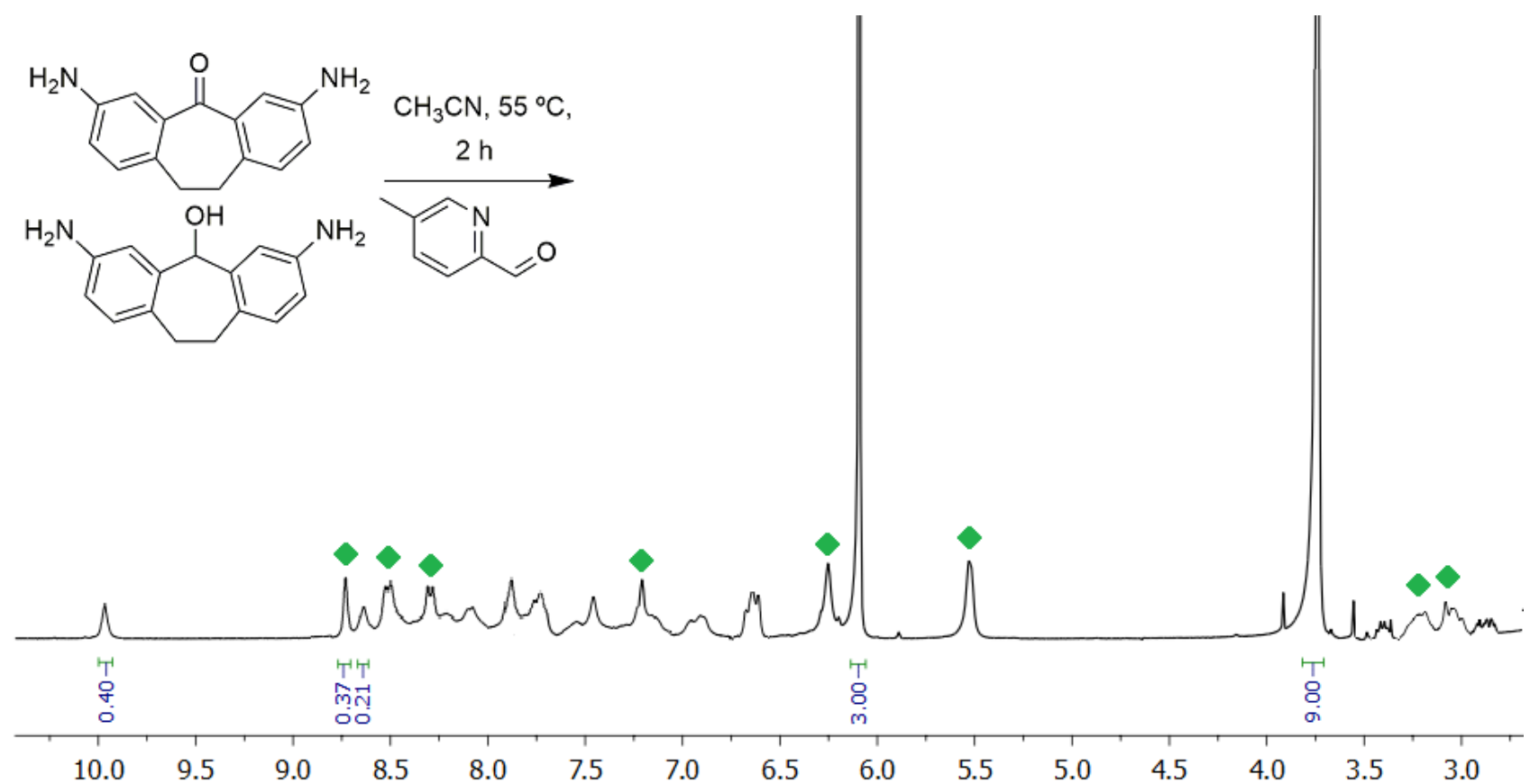

Figure S54. ${ }^{1} \mathrm{H}$ NMR spectra of products formed upon mixing suberone ligand $\mathbf{A}$, suberol ligand $\mathbf{B}$, and methyl-formylpyridine 6, with $\mathrm{Fe}\left(\mathrm{ClO}_{4}\right)_{2}$ and 1 equivalent 1,3,5-trimethyoxybenzene standard in an NMR tube with heating at $55^{\circ} \mathrm{C}$ over 2 hours $\left(\mathrm{CD}_{3} \mathrm{CN}, 400 \mathrm{MHz}, 298 \mathrm{~K}\right) .1 \cdot \mathrm{Me}_{6}$ peaks are marked in green. 


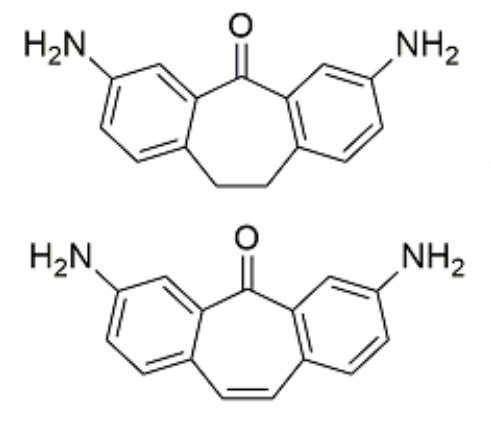

$\mathrm{CH}_{3} \mathrm{CN}, 55^{\circ} \mathrm{C}$,
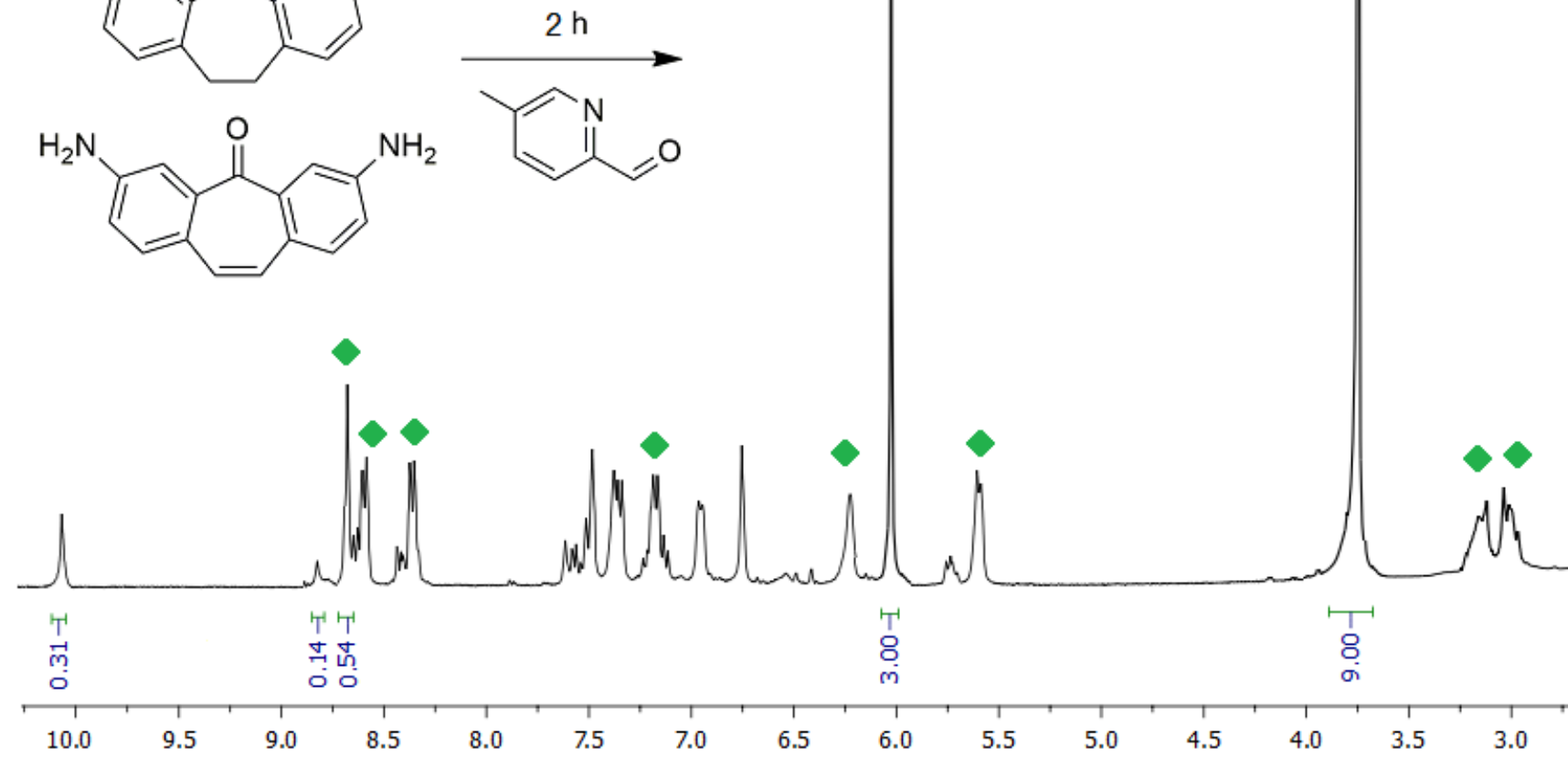

Figure S55. ${ }^{1} \mathrm{H}$ NMR spectra of products formed upon mixing suberone ligand $\mathbf{A}$, suberenone ligand $\mathbf{C}$, and methyl-formylpyridine 6, with $\mathrm{Fe}\left(\mathrm{ClO}_{4}\right)_{2}$ and 1 equivalent 1,3,5-trimethyoxybenzene standard in an NMR tube with heating at $55^{\circ} \mathrm{C}$ over 2 hours $\left(\mathrm{CD}_{3} \mathrm{CN}, 400 \mathrm{MHz}, 298 \mathrm{~K}\right)$. 


\section{Aldehyde Terminus Mixing Experiments}

\section{4a. Aldehyde Terminus Mixing Experiments with Suberone Ligand A}

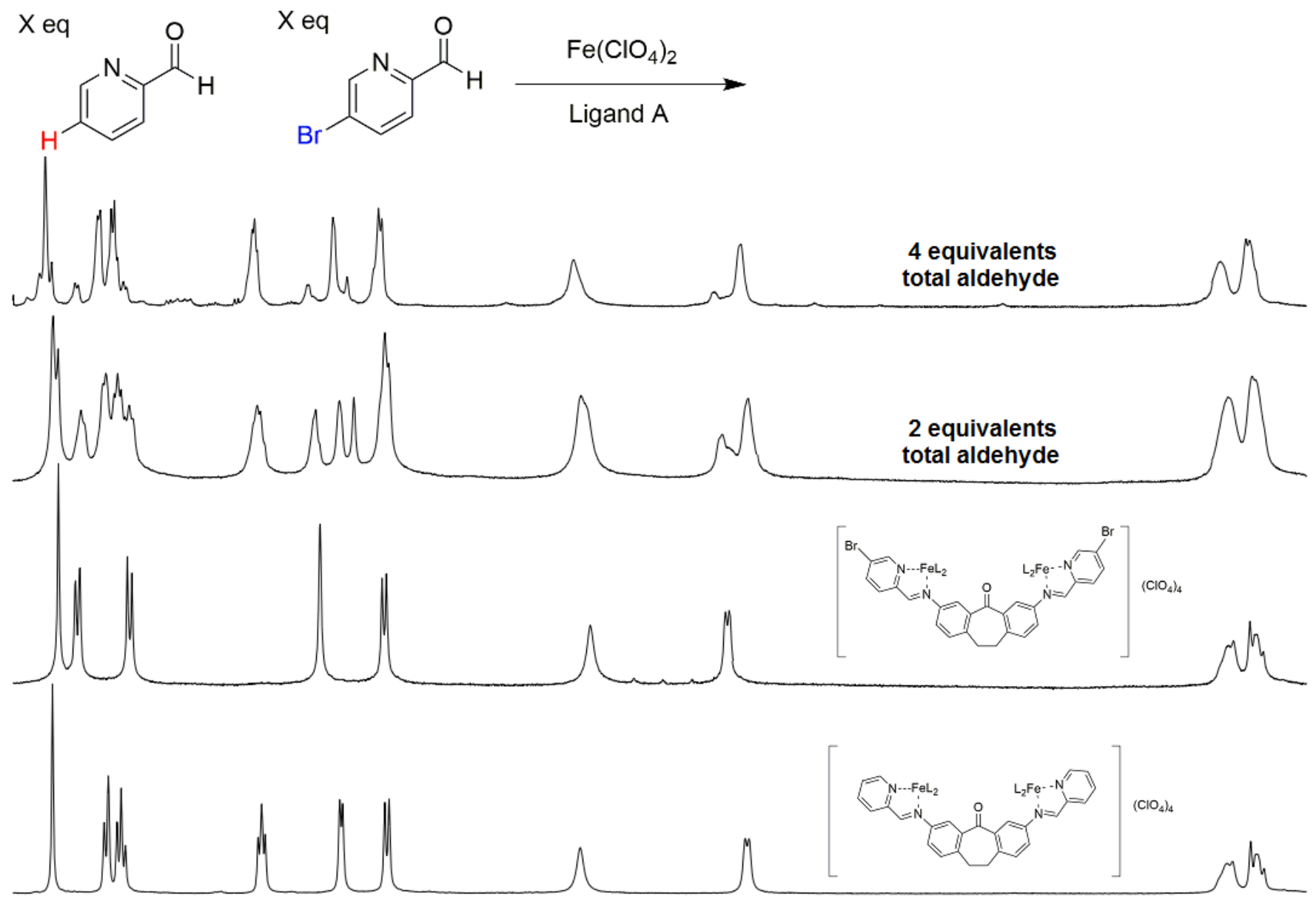

8.5

8.0

7.0

f1 6.0 (ppm)

Figure S56. ${ }^{1} \mathrm{H}$ NMR spectrum of product distributions formed upon mixing ligand $\mathbf{A}$ with $\mathrm{Fe}\left(\mathrm{ClO}_{4}\right)_{2}$ and equimolar amounts of formylpyridine 4 and bromo-formylpyridine 5 (two equivalents and four equivalents total) in $\mathrm{CH}_{3} \mathrm{CN}$ with heating at $55^{\circ} \mathrm{C}$ for $12 \mathrm{~h}\left(\mathrm{CD}_{3} \mathrm{CN}, 500 \mathrm{MHz}\right.$, spectra taken at $\left.298 \mathrm{~K}\right)$. 

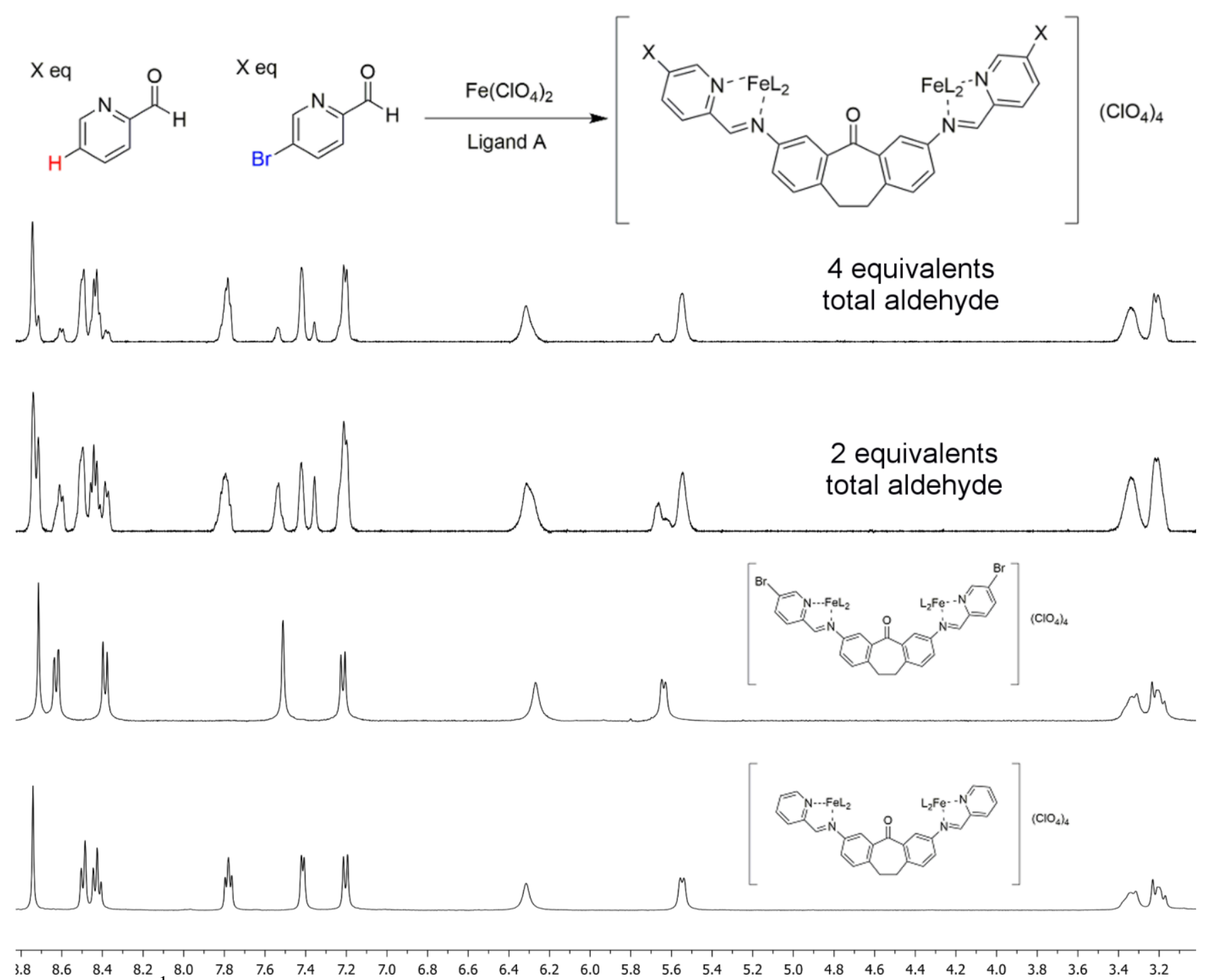

Figure S57. ${ }^{1} \mathrm{H}$ NMR spectrum of product distributions formed upon mixing ligand $\mathrm{A}$ with $\mathrm{Fe}\left(\mathrm{ClO}_{4}\right)_{2}$ and equimolar amounts of formylpyridine $\mathbf{4}$ and bromo-formylpyridine $\mathbf{5}$ (two equivalents and four equivalents total) in $\mathrm{CH}_{3} \mathrm{CN}$ with heating at $80{ }^{\circ} \mathrm{C}$ for $12 \mathrm{~h}\left(\mathrm{CD}_{3} \mathrm{CN}, 500 \mathrm{MHz}\right.$, spectra taken at $\left.298 \mathrm{~K}\right)$. 


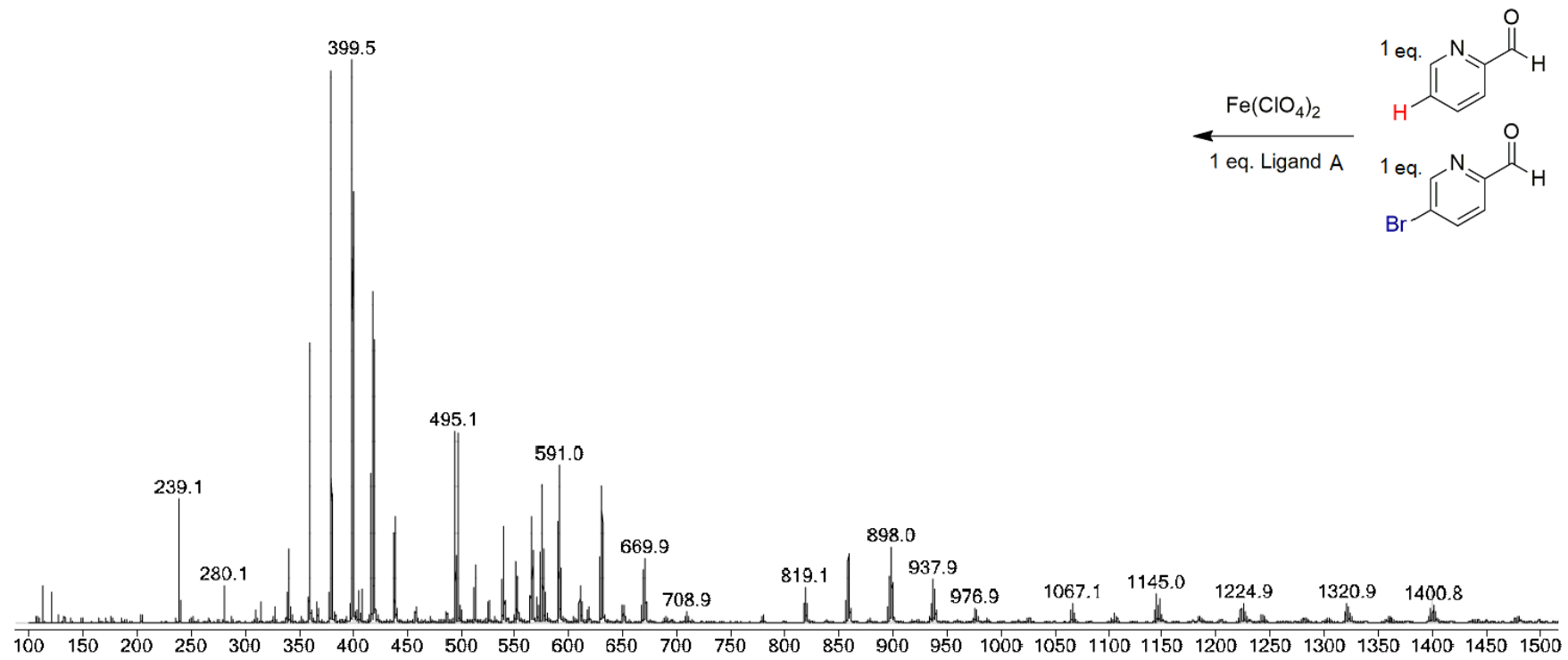

Figure S58. Full ESI-MS spectrum of product distribution formed upon mixing ligand $\mathbf{A}$ with $\mathrm{Fe}\left(\mathrm{ClO}_{4}\right)_{2}$ and equimolar amounts of formylpyridine $\mathbf{4}$ and bromo-formylpyridine 5 (two equivalents total) in $\mathrm{CH}_{3} \mathrm{CN}$ with heating at $55^{\circ} \mathrm{C}$ for $12 \mathrm{~h}\left(\mathrm{CH}_{3} \mathrm{CN}\right)$.

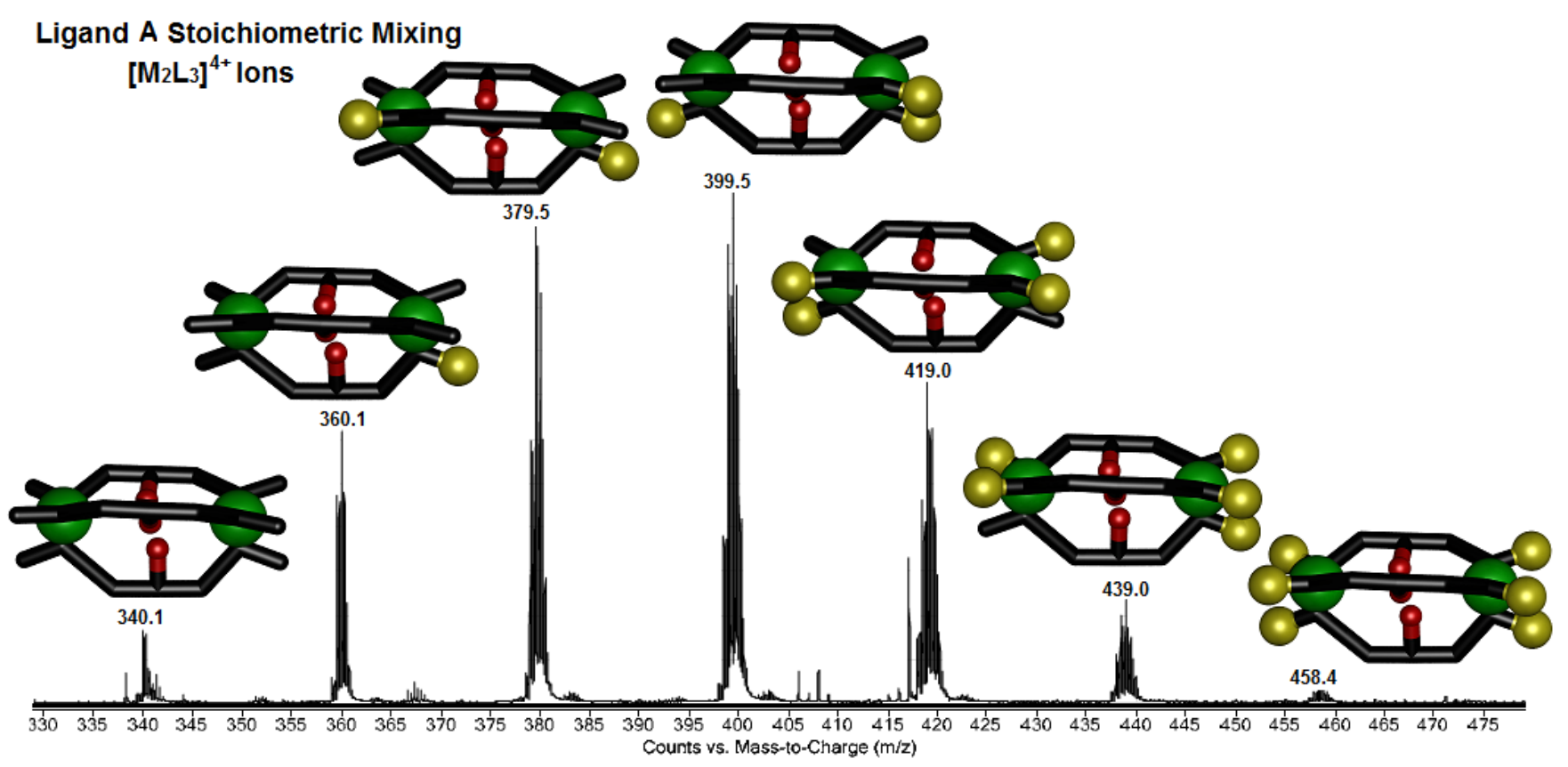

Figure S59. ESI-MS spectrum expansion of product distribution formed upon mixing ligand $\mathbf{A}$ with $\mathrm{Fe}\left(\mathrm{ClO}_{4}\right)_{2}$ and equimolar amounts of formylpyridine $\mathbf{4}$ and bromo-formylpyridine 5 (two equivalents total) in $\mathrm{CH}_{3} \mathrm{CN}$ with heating at $55^{\circ} \mathrm{C}$ for $12 \mathrm{~h}$. Peaks for the observed possible combinations of $\left[\left(\mathbf{1}^{\cdot} \mathrm{H}_{\mathrm{x}} \mathrm{Br}_{\mathrm{y}}\right)\right]^{4+}$ ions are shown $\left(\mathrm{CH}_{3} \mathrm{CN}\right)$. 


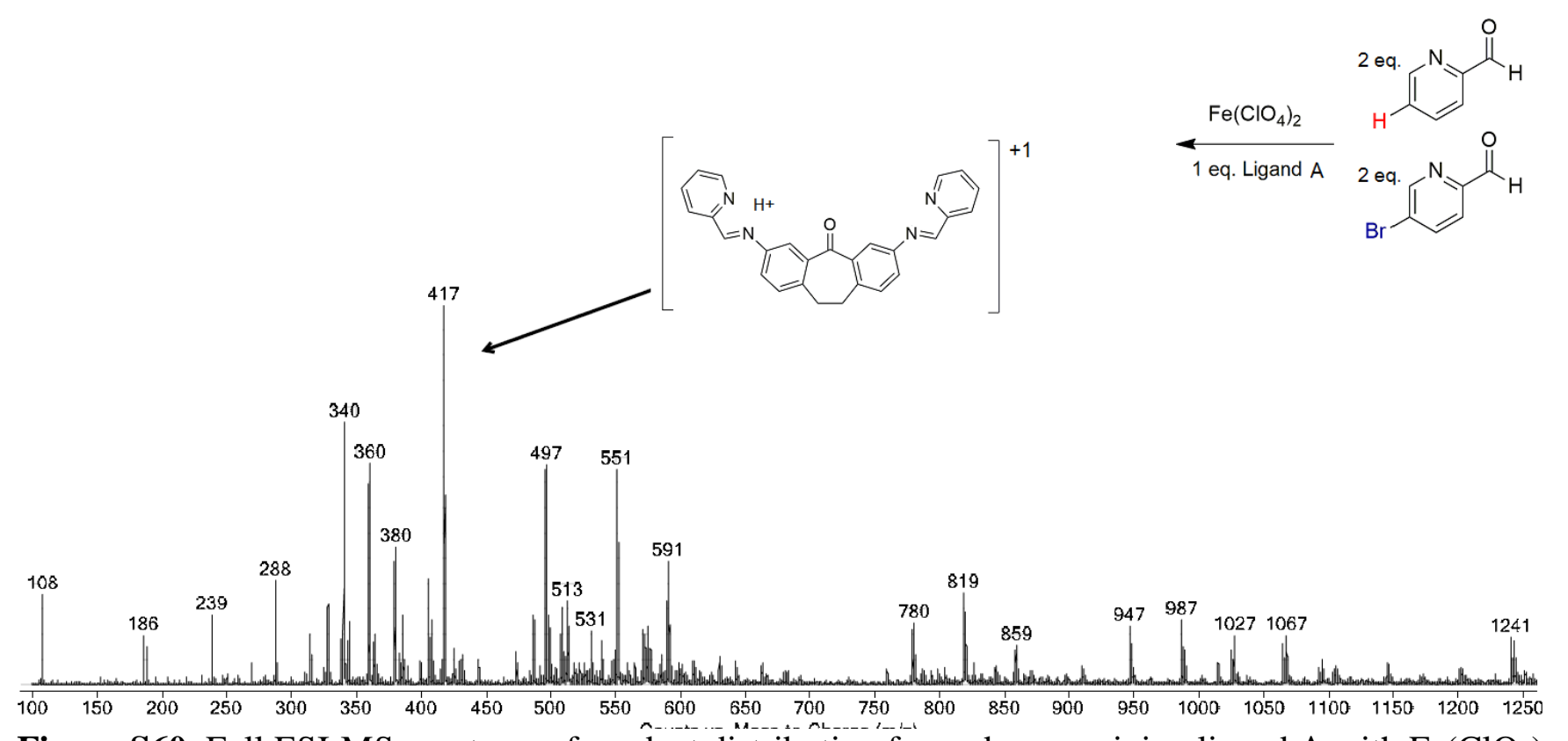

Figure S60. Full ESI-MS spectrum of product distribution formed upon mixing ligand A with $\mathrm{Fe}(\mathrm{ClO})_{2}$ and equimolar amounts of formylpyridine $\mathbf{4}$ and bromo-formylpyridine $\mathbf{5}$ (two equivalents total) in $\mathrm{CH}_{3} \mathrm{CN}$ with heating at $55^{\circ} \mathrm{C}$ for $12 \mathrm{~h}\left(\mathrm{CH}_{3} \mathrm{CN}\right)$.

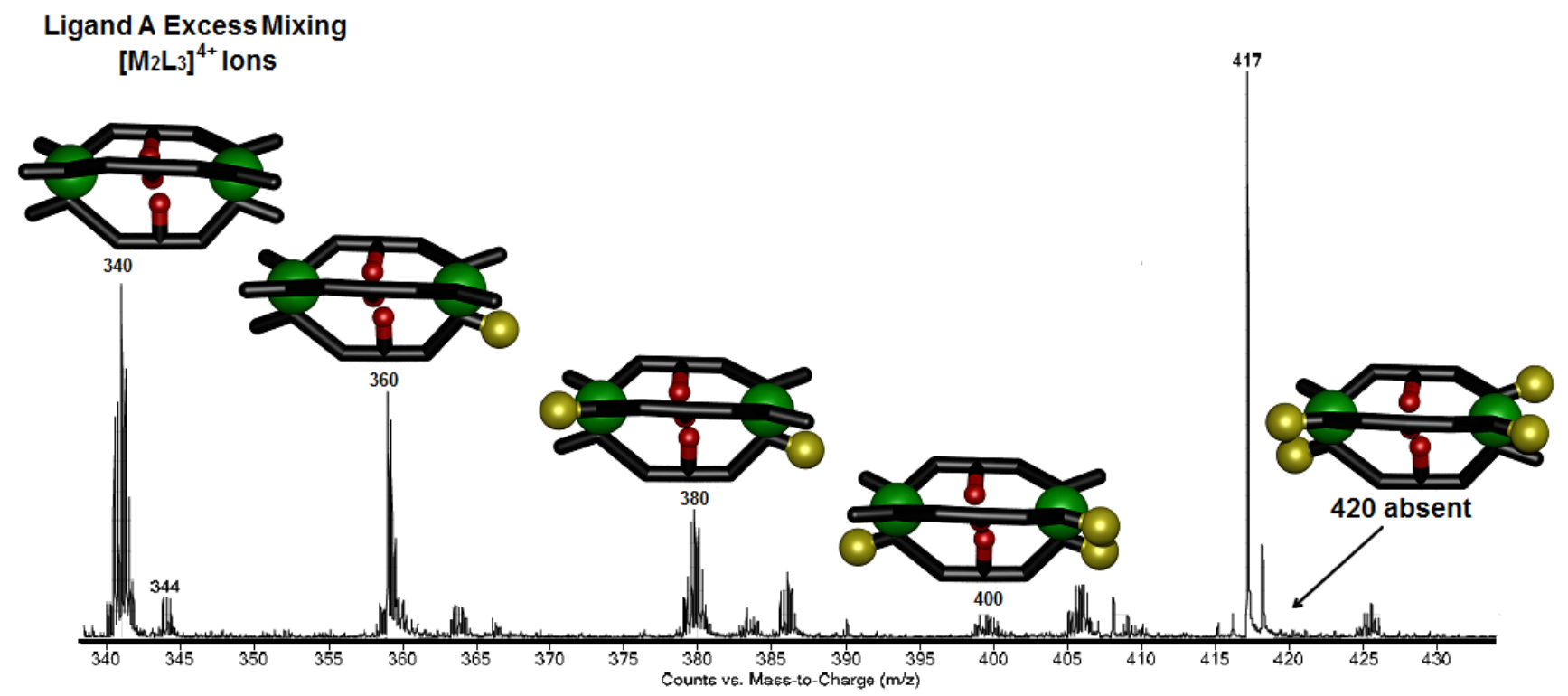

Figure S61. ESI-MS spectrum expansion of product distribution formed upon mixing ligand A with $\mathrm{Fe}\left(\mathrm{ClO}_{4}\right)_{2}$ and equimolar amounts of formylpyridine 4 and bromo-formylpyridine 5 (two equivalents total) in $\mathrm{CH}_{3} \mathrm{CN}$ with heating at $55{ }^{\circ} \mathrm{C}$ for $12 \mathrm{~h}$. Peaks for the observed possible combinations of $\left[\left(\mathbf{1} \cdot \mathrm{H}_{\mathrm{x}} \mathrm{Br}_{\mathrm{y}}\right)\right]^{4+}$ ions are shown $\left(\mathrm{CH}_{3} \mathrm{CN}\right)$. 
<smiles>[X]C(C)([O])[Na]</smiles><smiles>CC(C)=O</smiles><smiles>CCOC(=O)OC(C)C</smiles>

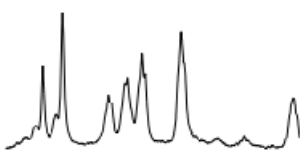<smiles>[AlH2]</smiles>

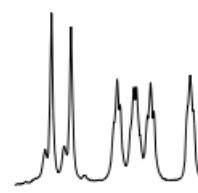
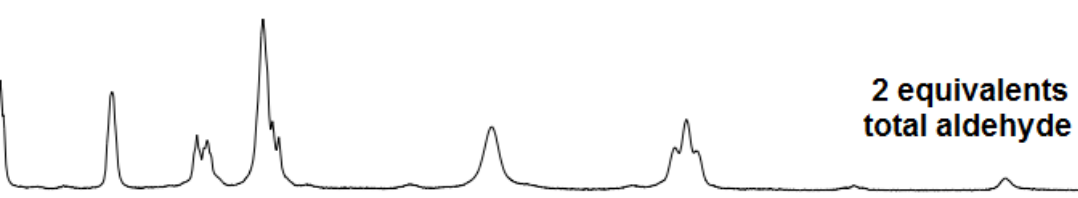

\section{4 equivalents total aldehyde}

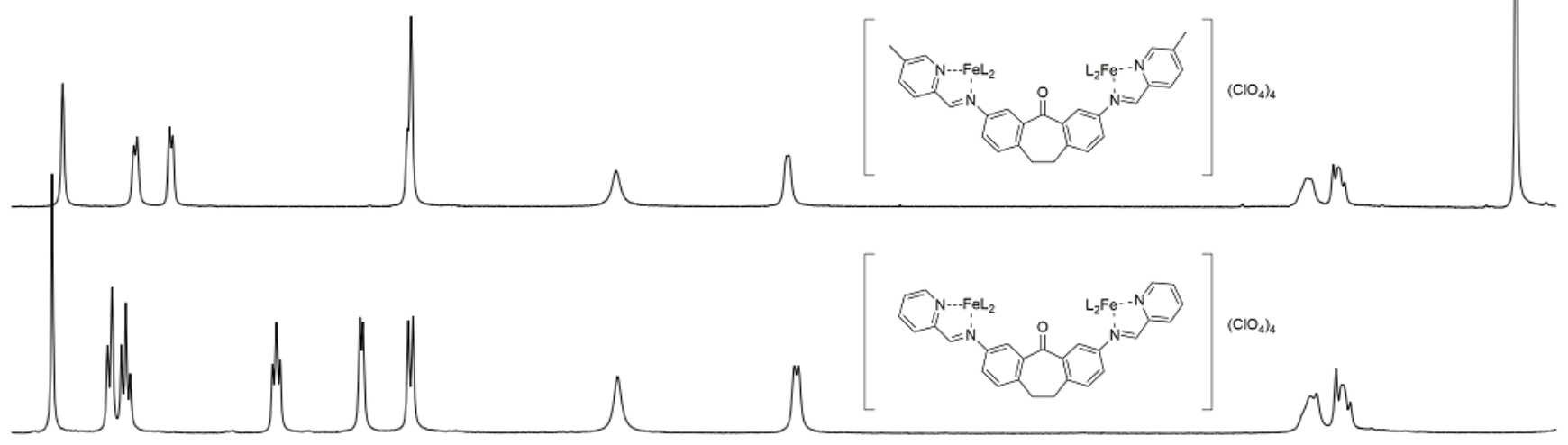

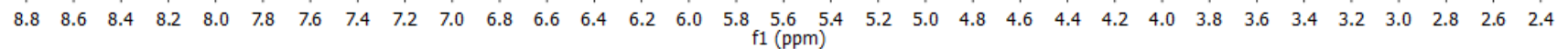

Figure S62. ${ }^{1} \mathrm{H}$ NMR spectrum of product distributions formed upon mixing ligand $\mathbf{A}$ with $\mathrm{Fe}\left(\mathrm{ClO}_{4}\right)_{2}$ and equimolar amounts of formylpyridine $\mathbf{4}$ and methyl-formylpyridine $\mathbf{6}$ (two equivalents and four equivalents total) in $\mathrm{CH}_{3} \mathrm{CN}$ with heating at $55^{\circ} \mathrm{C}$ for $12 \mathrm{~h}\left(\mathrm{CD}_{3} \mathrm{CN}, 500 \mathrm{MHz}\right.$, spectra taken at $\left.298 \mathrm{~K}\right)$. 

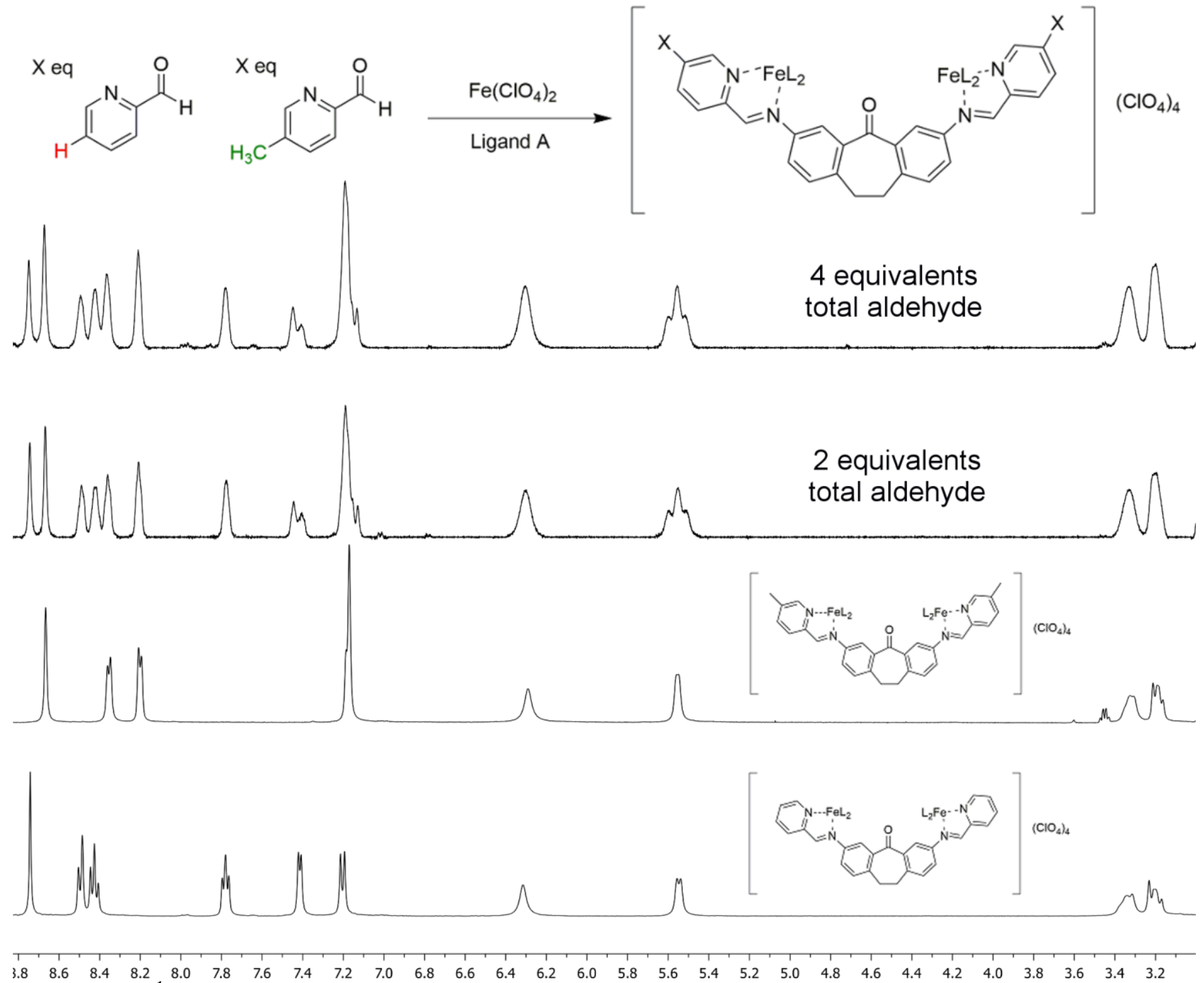

Figure S63. ${ }^{1} \mathrm{H}$ NMR spectrum of product distributions formed upon mixing ligand $\mathbf{A}$ with $\mathrm{Fe}\left(\mathrm{ClO}_{4}\right)_{2}$ and equimolar amounts of formylpyridine $\mathbf{4}$ and methyl-formylpyridine $\mathbf{6}$ (two equivalents and four equivalents total) in $\mathrm{CH}_{3} \mathrm{CN}$ with heating at $80{ }^{\circ} \mathrm{C}$ for $12 \mathrm{~h}\left(\mathrm{CD}_{3} \mathrm{CN}, 500 \mathrm{MHz}\right.$, spectra taken at $\left.298 \mathrm{~K}\right)$. 

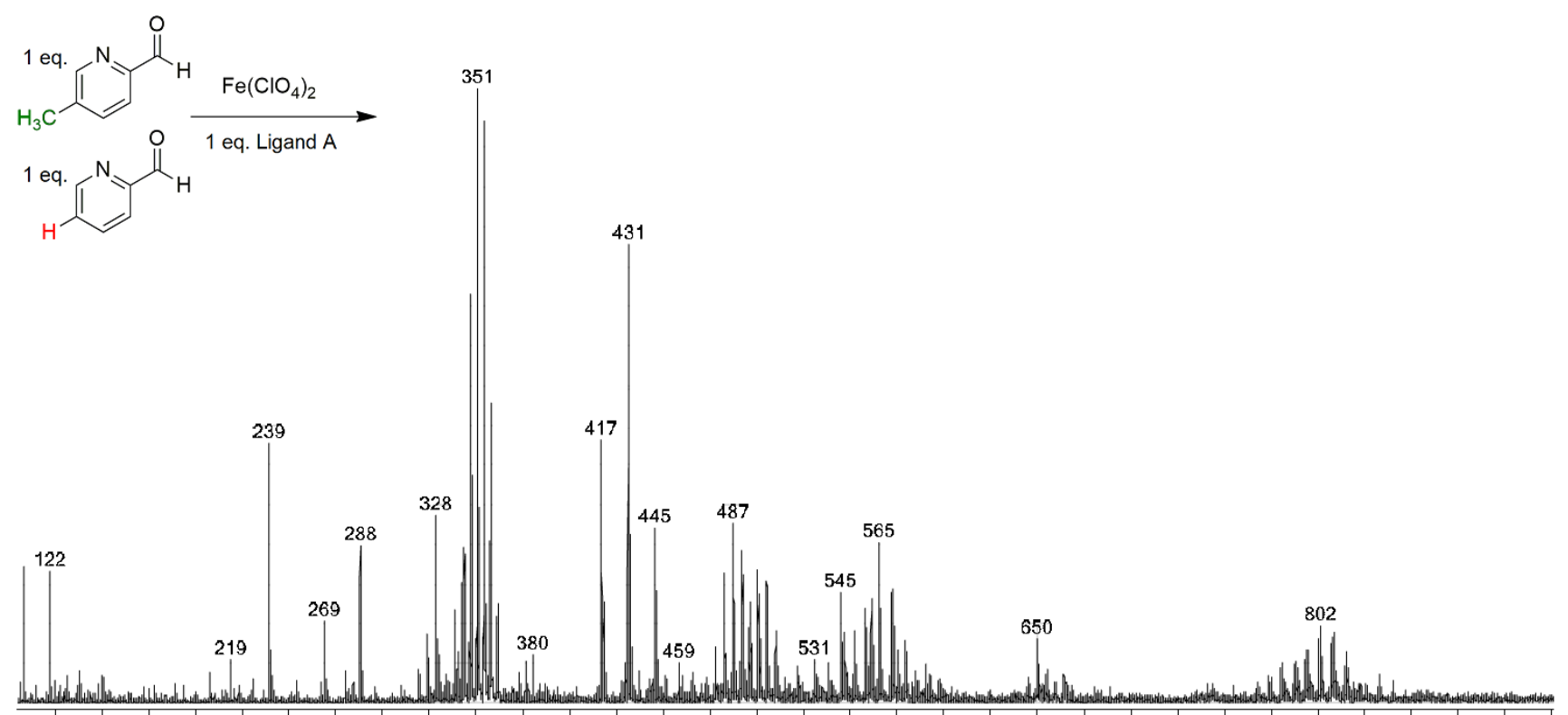

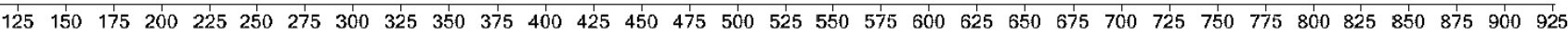

Figure S64. Full ESI-MS spectrum of product distribution formed upon mixing ligand A with $\mathrm{Fe}\left(\mathrm{ClO}_{4}\right)_{2}$ and equimolar amounts of formylpyridine $\mathbf{4}$ and methyl-formylpyridine $\mathbf{6}$ (two equivalents total) in $\mathrm{CH}_{3} \mathrm{CN}$ with heating at $55^{\circ} \mathrm{C}$ for $12 \mathrm{~h}\left(\mathrm{CH}_{3} \mathrm{CN}\right)$.

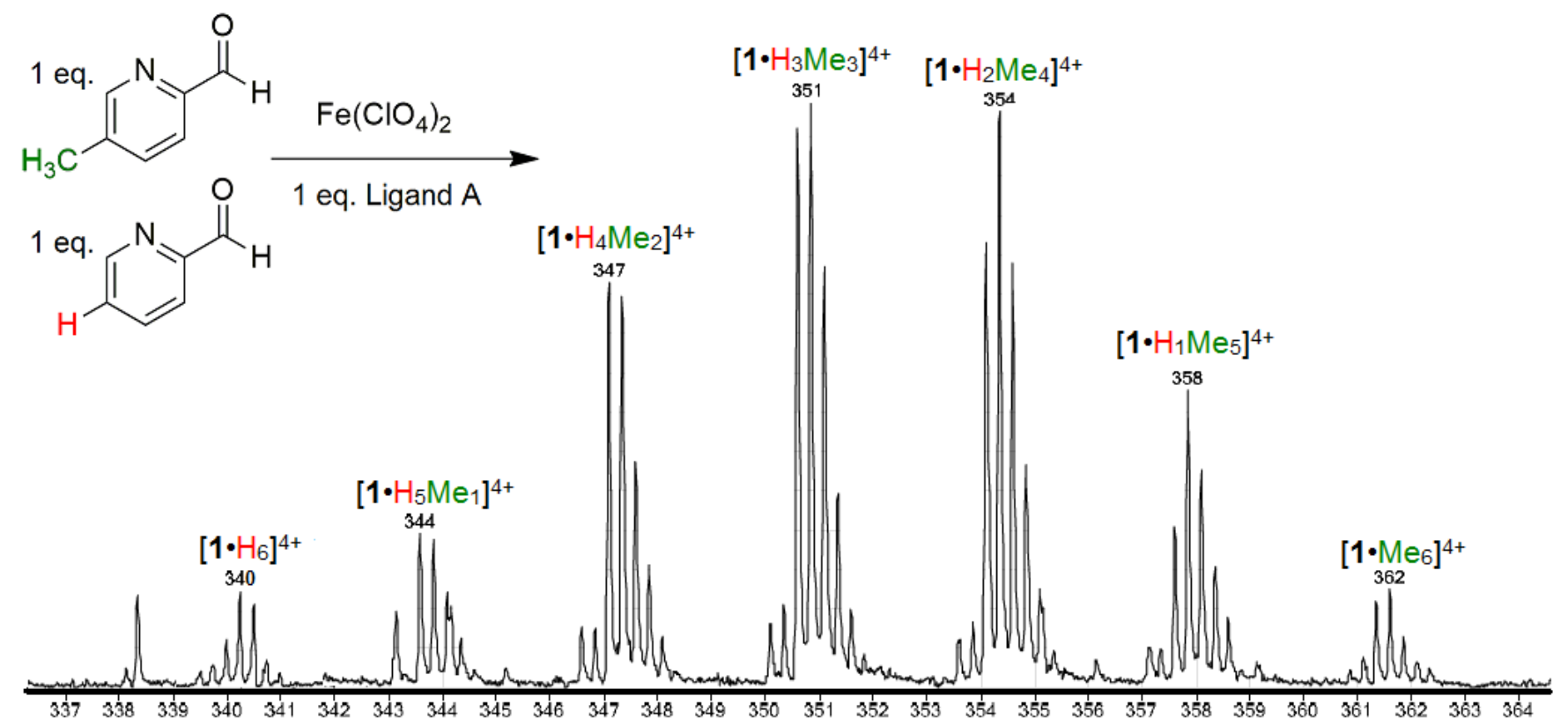

Figure S65. ESI-MS spectrum expansion of product distribution formed upon mixing ligand A with $\mathrm{Fe}\left(\mathrm{ClO}_{4}\right)_{2}$ and equimolar amounts of formylpyridine $\mathbf{4}$ and methyl-formylpyridine $\mathbf{6}$ (two equivalents total) in $\mathrm{CH}_{3} \mathrm{CN}$ with heating at $55{ }^{\circ} \mathrm{C}$ for $12 \mathrm{~h}$. Peaks for the observed possible combinations of $\left[\left(\mathbf{1} \cdot \mathrm{H}_{\mathrm{x}} \mathrm{Me}_{\mathrm{y}}\right)\right]^{4+}$ ions are shown $\left(\mathrm{CH}_{3} \mathrm{CN}\right)$. 

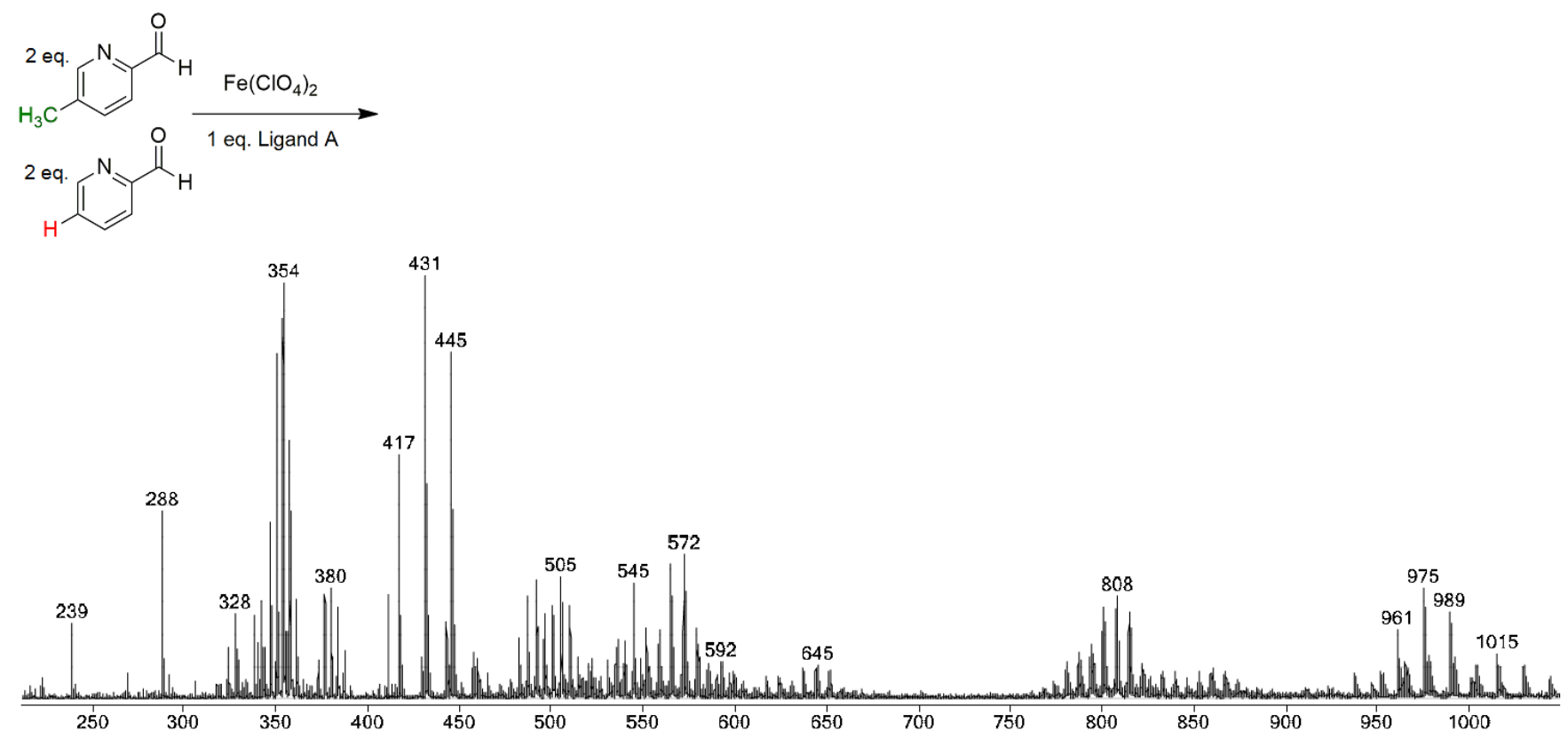

Figure S66. Full ESI-MS spectrum of product distribution formed upon mixing ligand A with $\mathrm{Fe}\left(\mathrm{ClO}_{4}\right)_{2}$ and equimolar amounts of formylpyridine $\mathbf{4}$ and methyl-formylpyridine $\mathbf{6}$ (four equivalents total) in $\mathrm{CH}_{3} \mathrm{CN}$ with heating at $55^{\circ} \mathrm{C}$ for $12 \mathrm{~h}\left(\mathrm{CH}_{3} \mathrm{CN}\right)$.

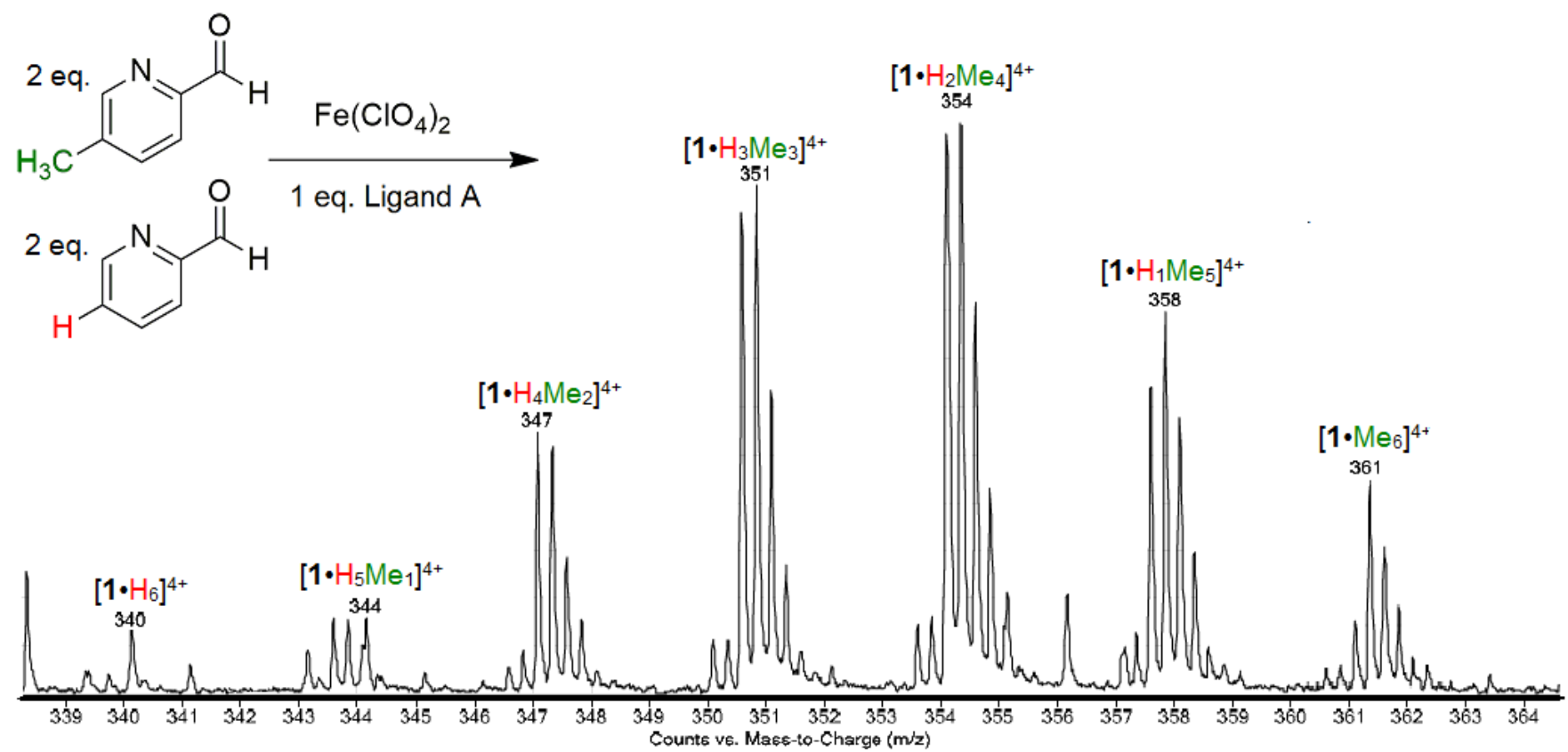

Figure S67. ESI-MS spectrum expansion of product distribution formed upon mixing ligand A with $\mathrm{Fe}\left(\mathrm{ClO}_{4}\right)_{2}$ and equimolar amounts of formylpyridine $\mathbf{4}$ and methyl-formylpyridine $\mathbf{6}$ (four equivalents total) in $\mathrm{CH}_{3} \mathrm{CN}$ with heating at $55{ }^{\circ} \mathrm{C}$ for $12 \mathrm{~h}$. Peaks for the observed possible combinations of $\left[\left(\mathbf{1} \cdot \mathrm{H}_{\mathrm{x}} \mathrm{Me}_{\mathrm{y}}\right)\right]^{4+}$ ions are shown $\left(\mathrm{CH}_{3} \mathrm{CN}\right)$. 


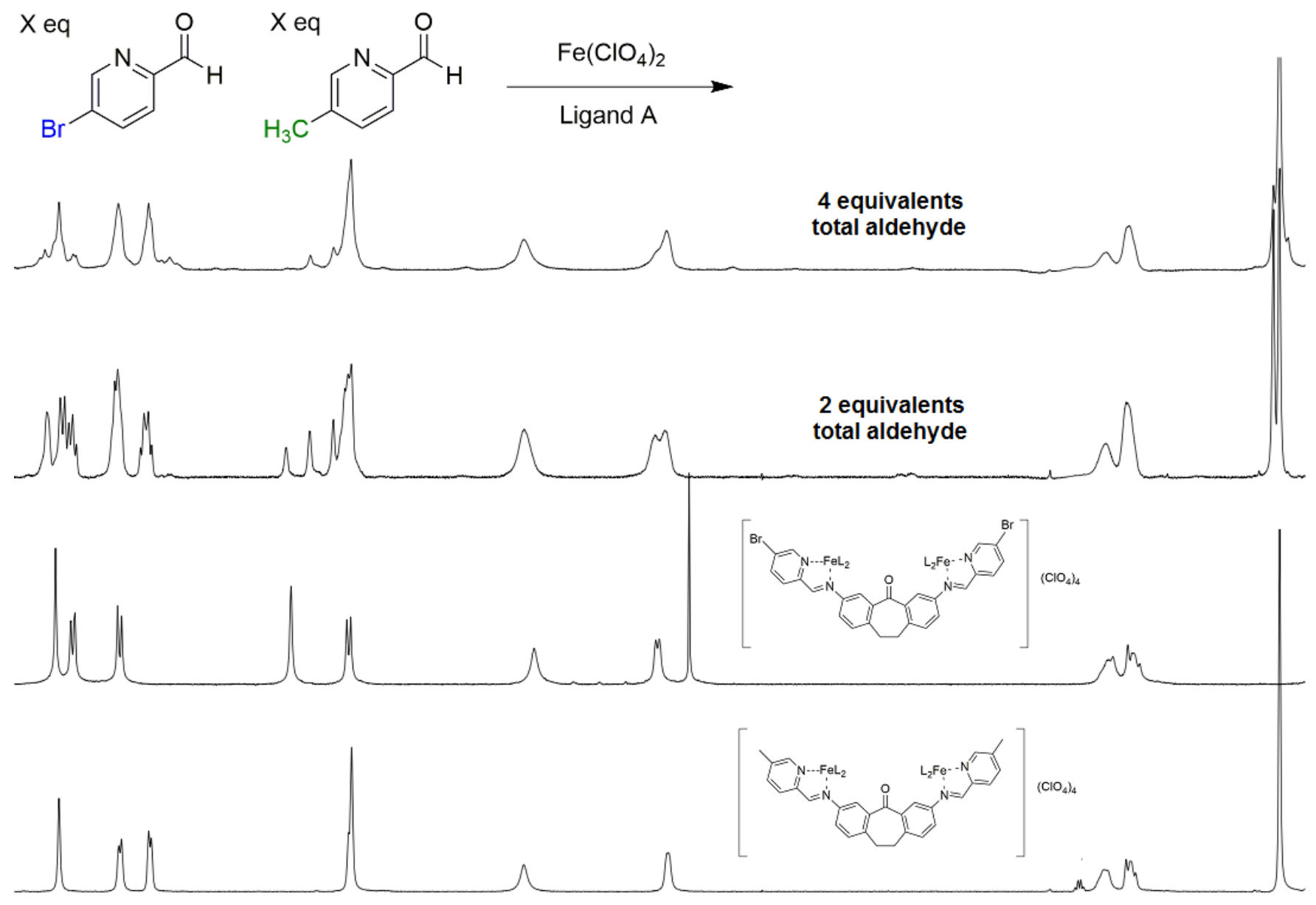

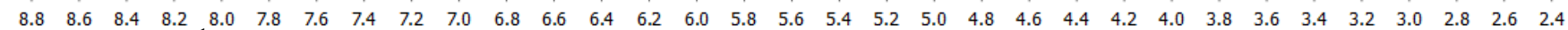
Figure S68. ${ }^{1} \mathrm{H}$ NMR spectrum of product distributions formed upon mixing ligand $\mathbf{A}$ with $\mathrm{Fe}\left(\mathrm{ClO}_{4}\right)_{2}$ and equimolar amounts of bromo-formylpyridine $\mathbf{5}$ and methyl-formylpyridine $\mathbf{6}$ (two equivalents and four equivalents total) in $\mathrm{CH}_{3} \mathrm{CN}$ with heating at $55{ }^{\circ} \mathrm{C}$ for $12 \mathrm{~h}\left(\mathrm{CD}_{3} \mathrm{CN}, 500 \mathrm{MHz}\right.$, spectra taken at $\left.298 \mathrm{~K}\right)$. 


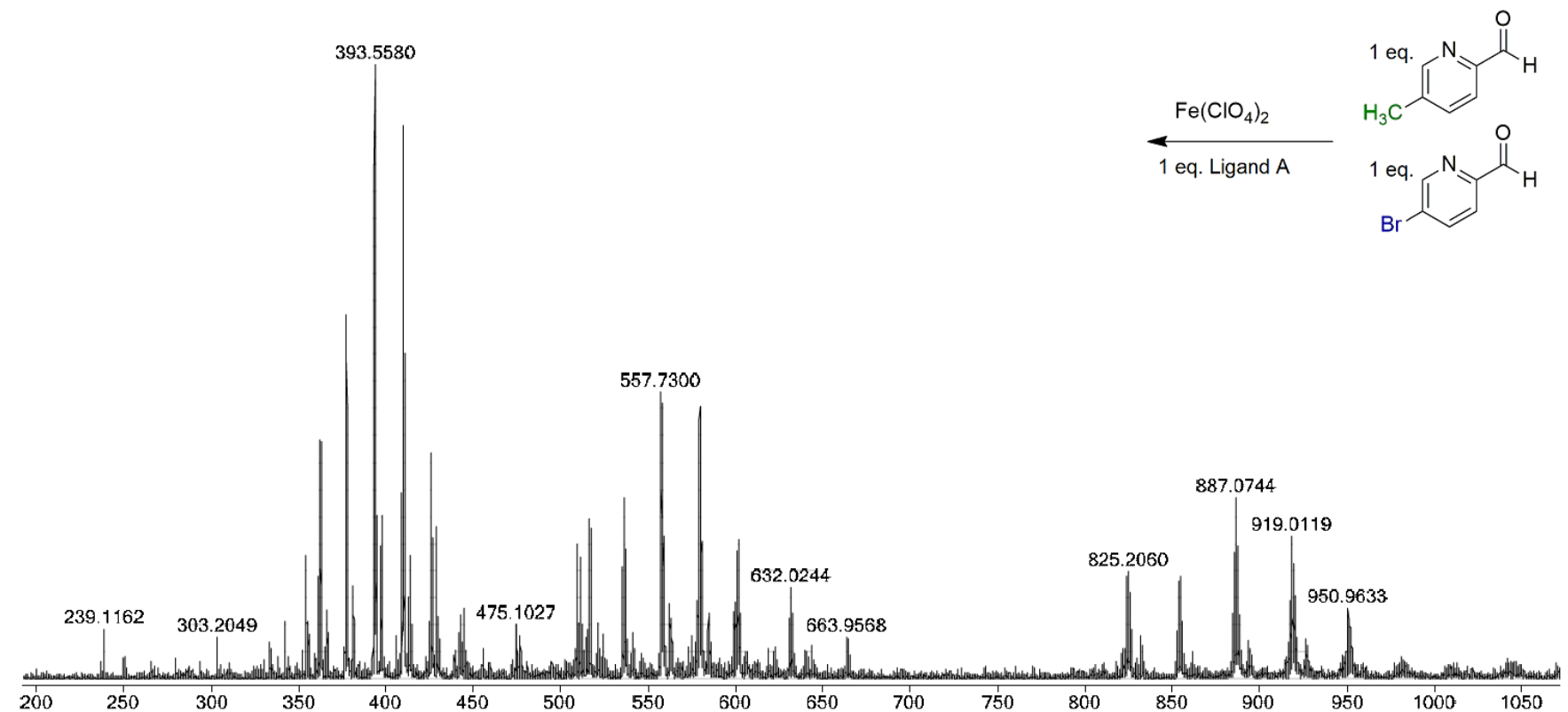

Figure S69. Full ESI-MS spectrum of product distribution formed upon mixing ligand A with $\mathrm{Fe}\left(\mathrm{ClO}_{4}\right)_{2}$ and equimolar amounts of bromo-formylpyridine $\mathbf{5}$ and methyl-formylpyridine $\mathbf{6}$ (two equivalents total) in $\mathrm{CH}_{3} \mathrm{CN}$ with heating at $55^{\circ} \mathrm{C}$ for $12 \mathrm{~h}\left(\mathrm{CH}_{3} \mathrm{CN}\right)$.

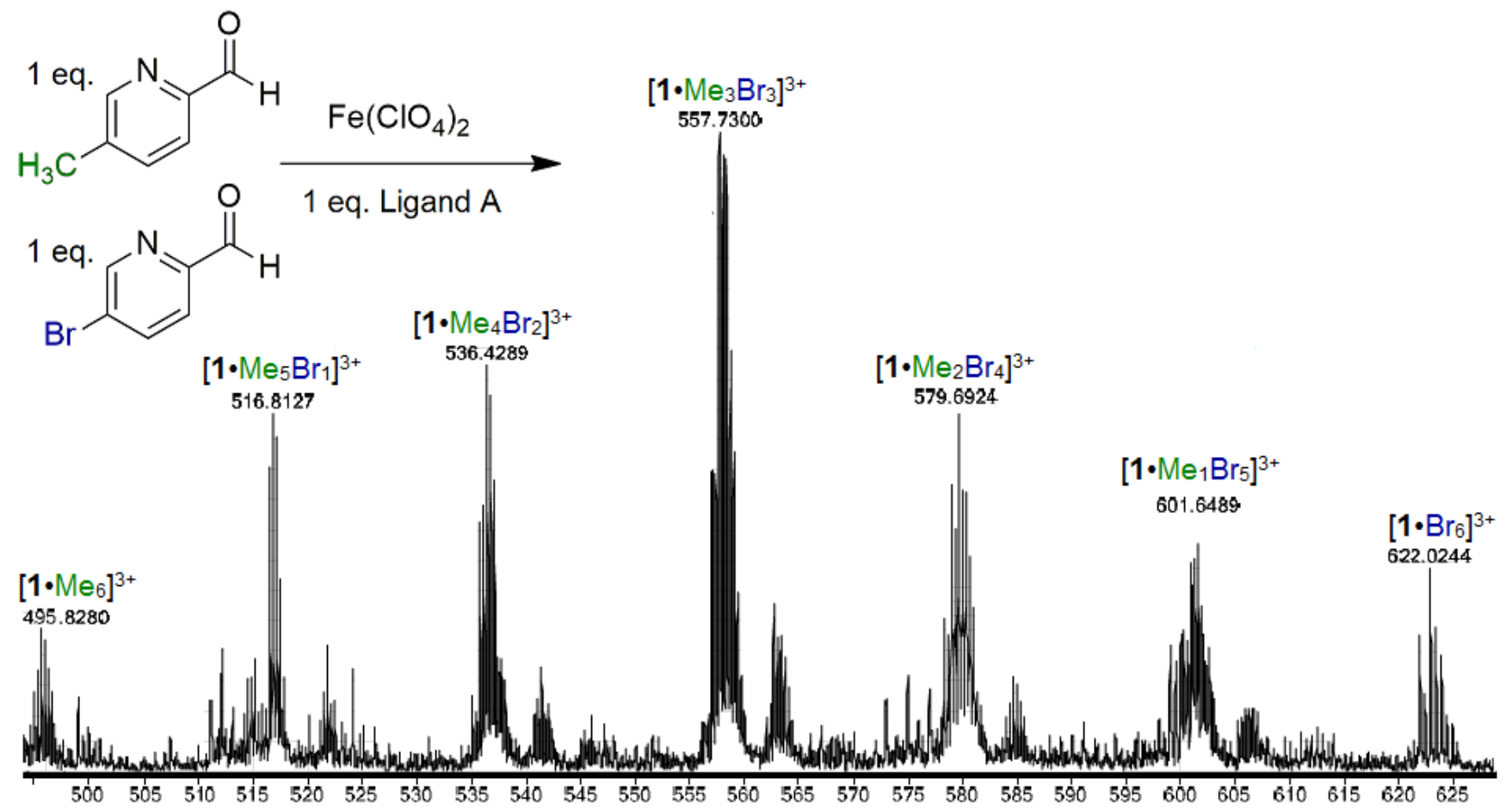

Figure S70. ESI-MS spectrum expansion of product distribution formed upon mixing ligand $\mathbf{A}$ with $\mathrm{Fe}\left(\mathrm{ClO}_{4}\right)_{2}$ and equimolar amounts of bromo-formylpyridine 5 and methyl-formylpyridine 6 (two equivalents total) in $\mathrm{CH}_{3} \mathrm{CN}$ with heating at $55{ }^{\circ} \mathrm{C}$ for $12 \mathrm{~h}$. Peaks for the observed possible combinations of $\left[\left(\mathbf{1} \cdot \mathrm{Me}_{\mathrm{x}} \mathrm{Br}_{\mathrm{y}}\right) \cdot \mathrm{ClO}_{4}\right]^{3+}$ ions are shown $\left(\mathrm{CH}_{3} \mathrm{CN}\right)$. 


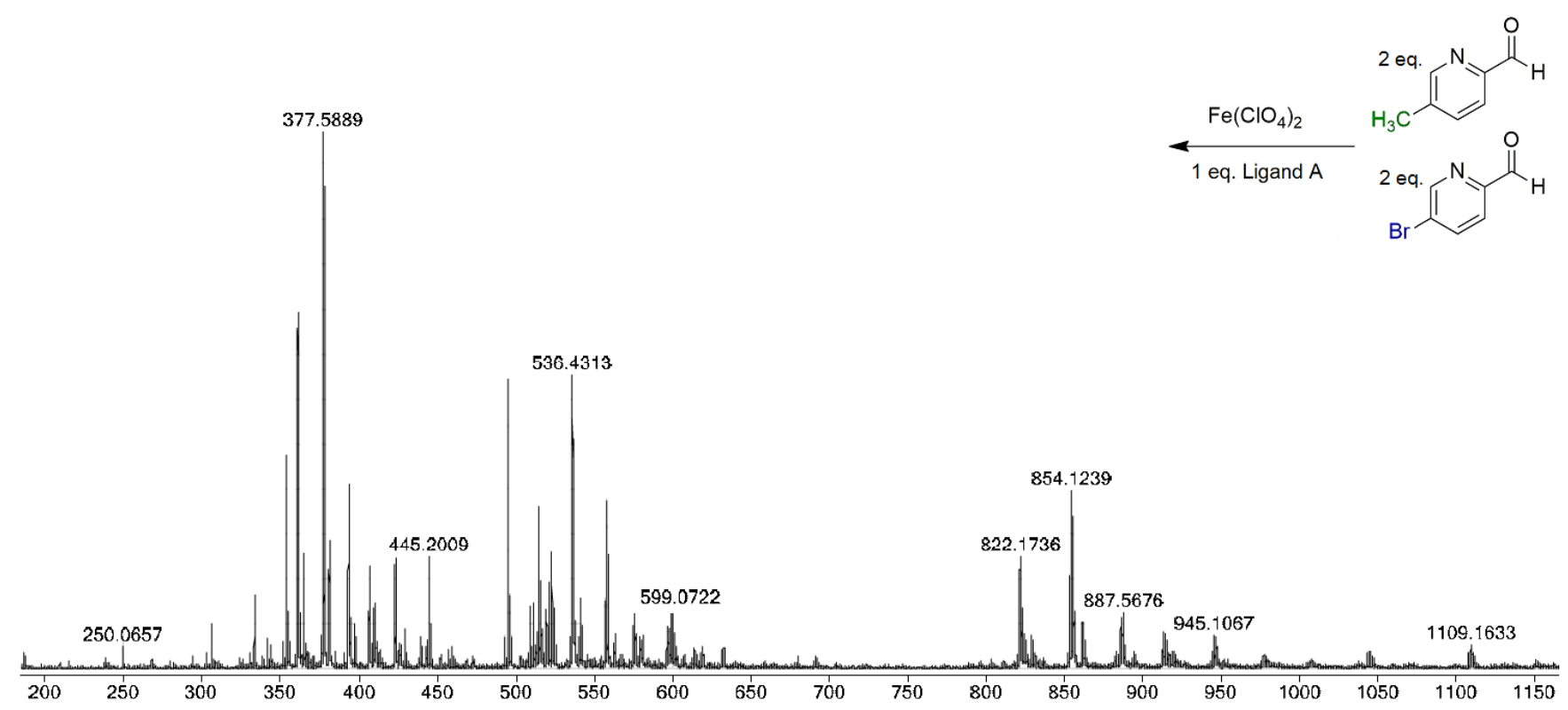

Figure S71. Full ESI-MS spectrum of product distribution formed upon mixing ligand A with $\mathrm{Fe}\left(\mathrm{ClO}_{4}\right)_{2}$ and equimolar amounts of bromo-formylpyridine $\mathbf{5}$ and methyl-formylpyridine $\mathbf{6}$ (four equivalents total) in $\mathrm{CH}_{3} \mathrm{CN}$ with heating at $55^{\circ} \mathrm{C}$ for $12 \mathrm{~h}\left(\mathrm{CH}_{3} \mathrm{CN}\right)$.

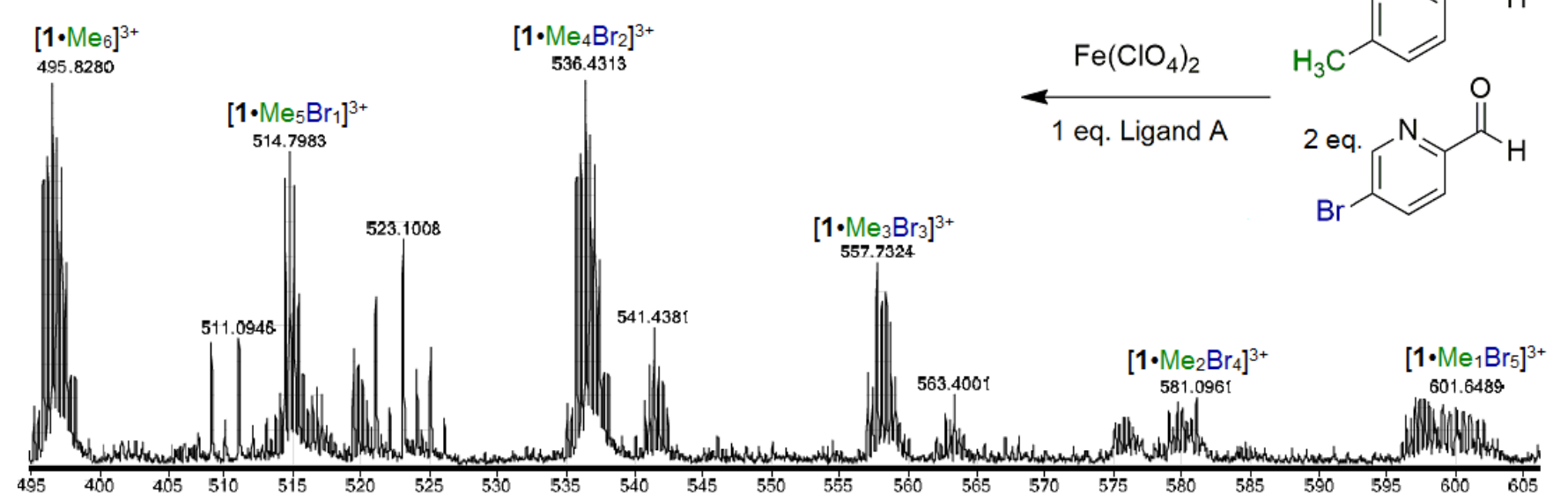

Figure S72. ESI-MS spectrum expansion of product distribution formed upon mixing ligand A with $\mathrm{Fe}\left(\mathrm{ClO}_{4}\right)_{2}$ and equimolar amounts of bromo-formylpyridine 5 and methyl-formylpyridine $\mathbf{6}$ (four equivalents total) in $\mathrm{CH}_{3} \mathrm{CN}$ with heating at $55^{\circ} \mathrm{C}$ for $12 \mathrm{~h}$. Peaks for the observed possible combinations of $\left[\left(\mathbf{1} \cdot \mathrm{Me}_{\mathrm{x}} \mathrm{Br}_{\mathrm{y}}\right) \cdot \mathrm{ClO}_{4}\right]^{3+}$ ions are shown $\left(\mathrm{CH}_{3} \mathrm{CN}\right)$. 


\section{4b. Aldehyde Terminus Mixing with Suberol Ligand B}<smiles></smiles>
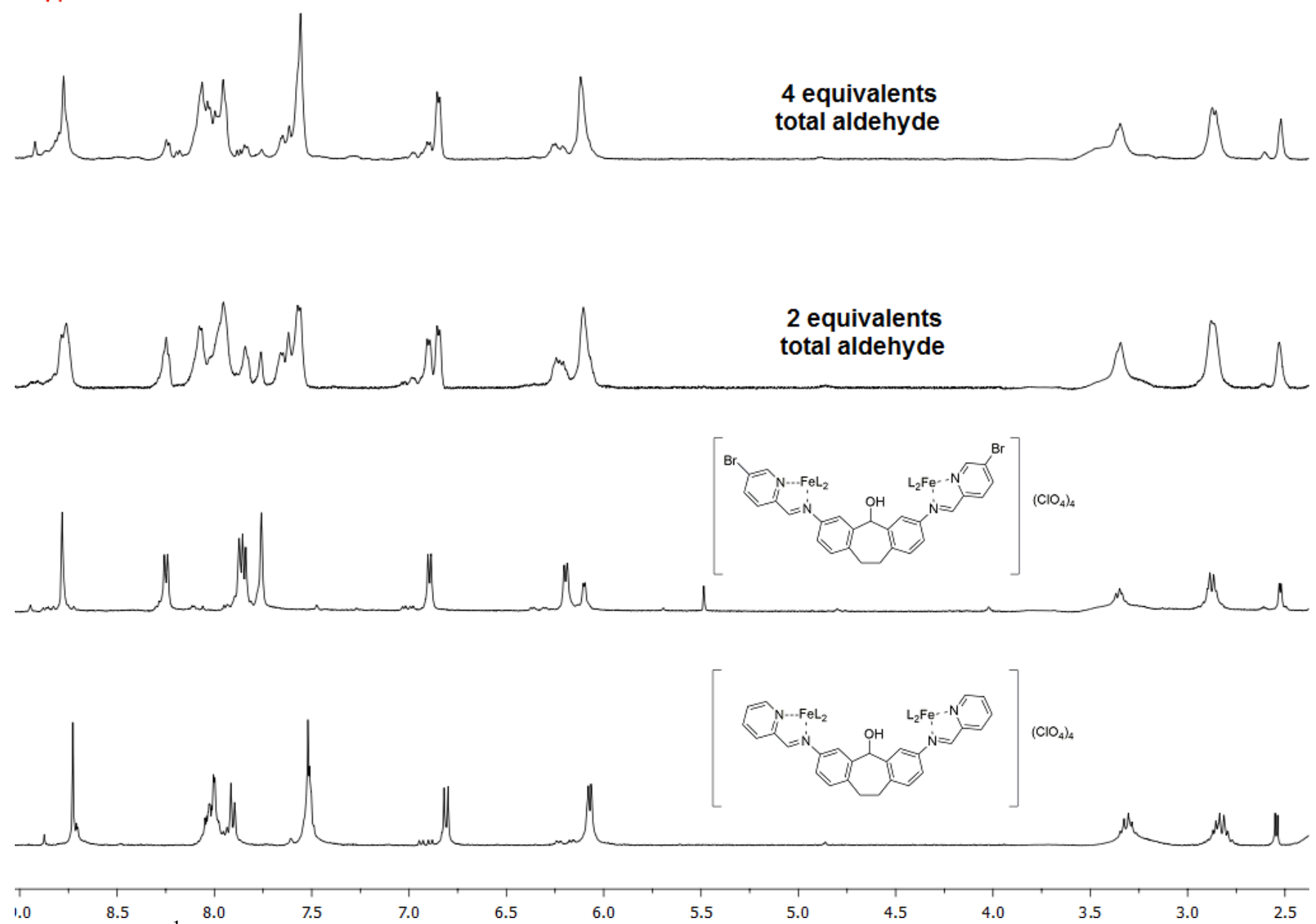

Figure S73. ${ }^{1} \mathrm{H}$ NMR spectrum of product distributions formed upon mixing ligand $\mathbf{B}$ with $\mathrm{Fe}\left(\mathrm{ClO}_{4}\right)_{2}$ and equimolar amounts of formylpyridine $\mathbf{4}$ and bromo-formylpyridine $\mathbf{5}$ (two equivalents and four equivalents total) in $\mathrm{CH}_{3} \mathrm{CN}$ with heating at $55^{\circ} \mathrm{C}$ for $12 \mathrm{~h}\left(\mathrm{CD}_{3} \mathrm{CN}, 500 \mathrm{MHz}\right.$, spectrum obtained at 298 $\mathrm{K})$. 


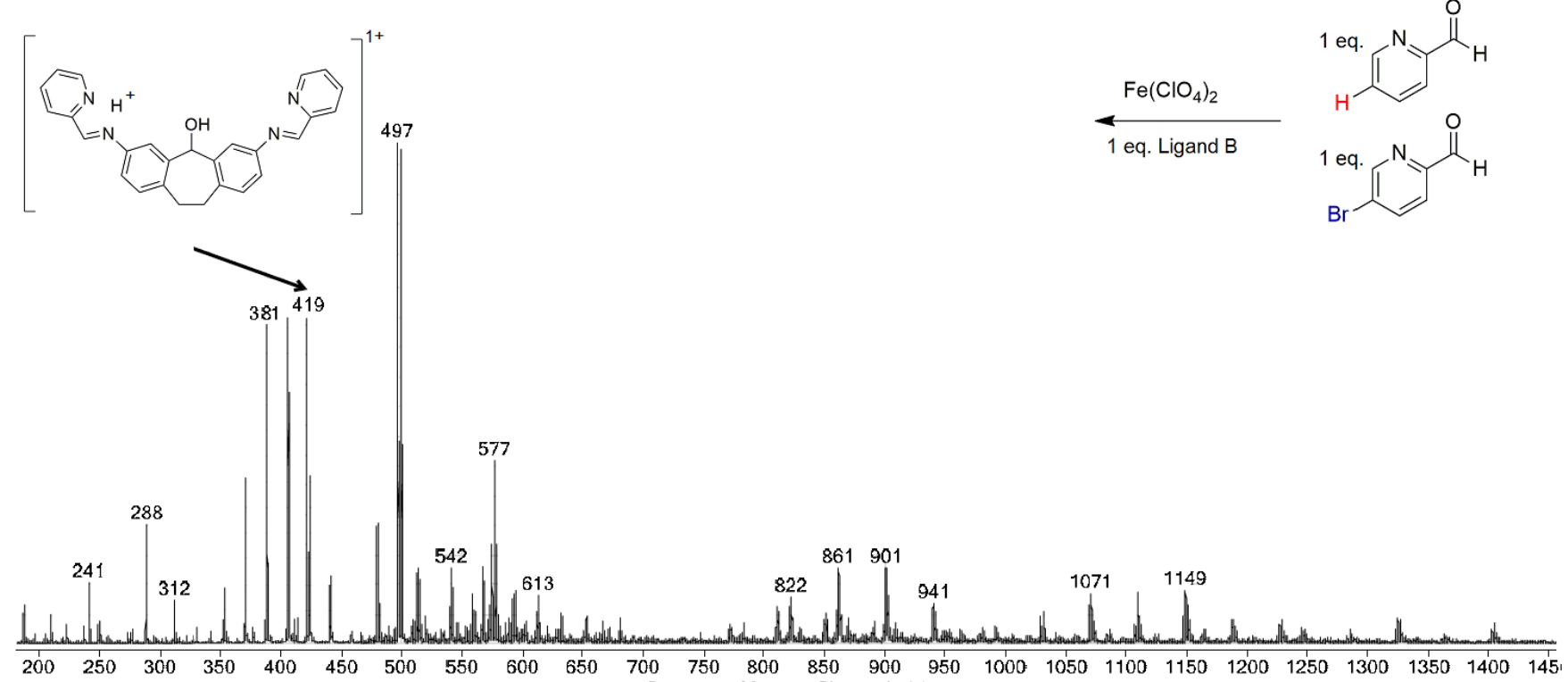

Figure S74. Full ESI-MS spectrum of product distribution formed upon mixing ligand $\mathbf{B}$ with $\mathrm{Fe}\left(\mathrm{ClO}_{4}\right)_{2}$ and equimolar amounts of formylpyridine $\mathbf{4}$ and bromo-formylpyridine $\mathbf{5}$ (two equivalents total) in $\mathrm{CH}_{3} \mathrm{CN}$ with heating at $55^{\circ} \mathrm{C}$ for $12 \mathrm{~h}\left(\mathrm{CH}_{3} \mathrm{CN}\right)$.

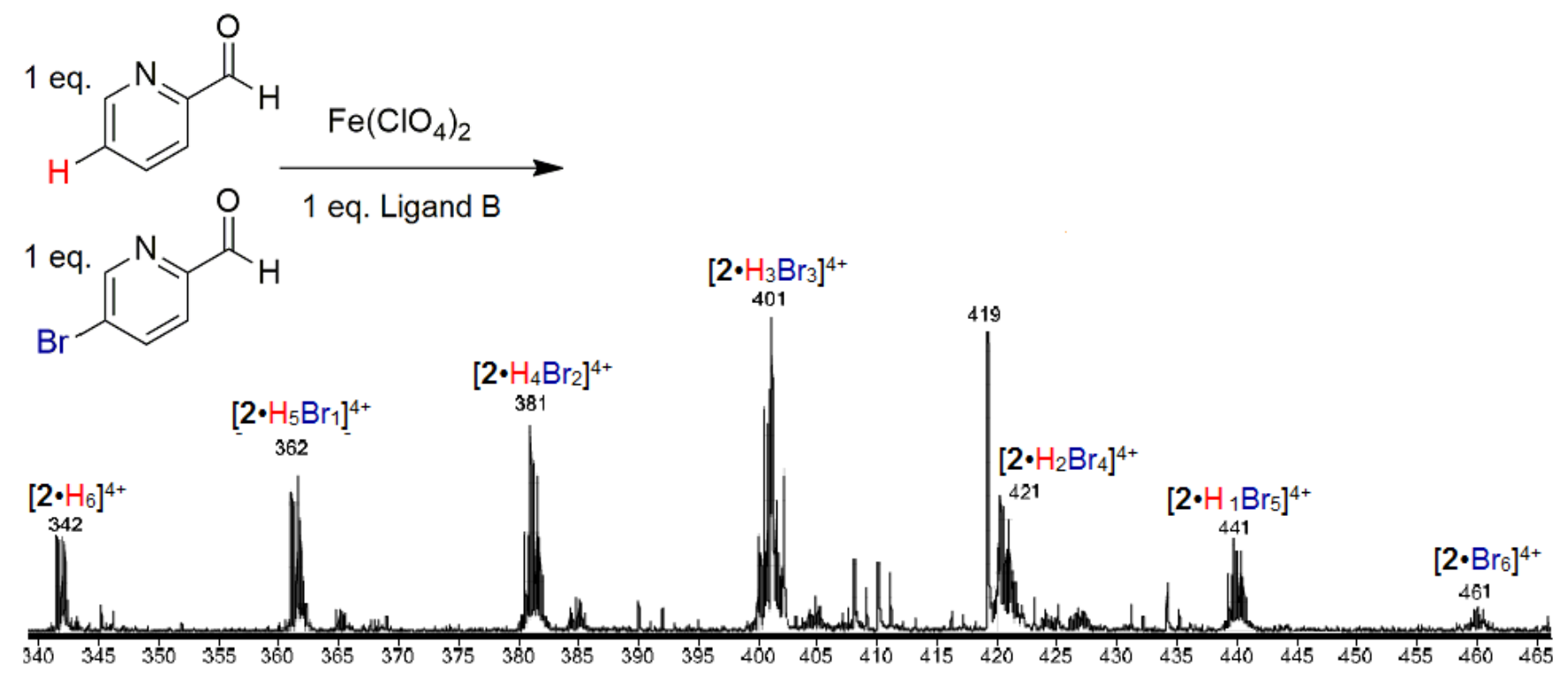

Figure S75. ESI-MS spectrum expansion of product distribution formed upon mixing ligand $\mathbf{B}$ with $\mathrm{Fe}\left(\mathrm{ClO}_{4}\right)_{2}$ and equimolar amounts of formylpyridine 4 and bromo-formylpyridine 5 (two equivalents total) in $\mathrm{CH}_{3} \mathrm{CN}$ with heating at $55{ }^{\circ} \mathrm{C}$ for $12 \mathrm{~h}$. Peaks for the observed possible combinations of $\left[\left(2 \cdot \mathrm{H}_{\mathrm{x}} \mathrm{Br}_{\mathrm{y}}\right)\right]^{4+}$ ions are shown $\left(\mathrm{CH}_{3} \mathrm{CN}\right)$. 


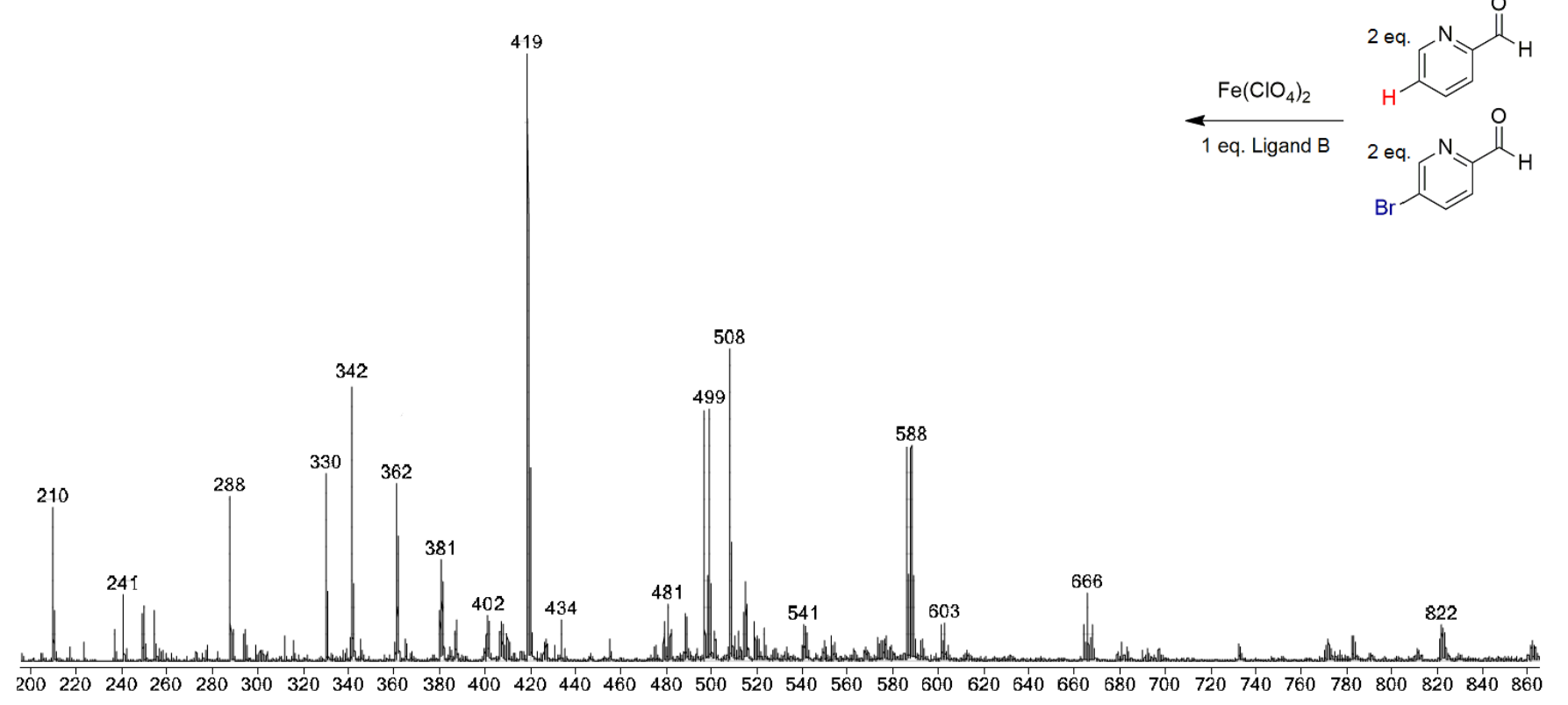

Figure S76. Full ESI-MS spectrum of product distribution formed upon mixing ligand $\mathbf{B}$ with $\mathrm{Fe}\left(\mathrm{ClO}_{4}\right)_{2}$ and equimolar amounts of formylpyridine $\mathbf{4}$ and bromo-formylpyridine $\mathbf{5}$ (four equivalents total) in $\mathrm{CH}_{3} \mathrm{CN}$ with heating at $55^{\circ} \mathrm{C}$ for $12 \mathrm{~h}$ shown $\left(\mathrm{CH}_{3} \mathrm{CN}\right)$.

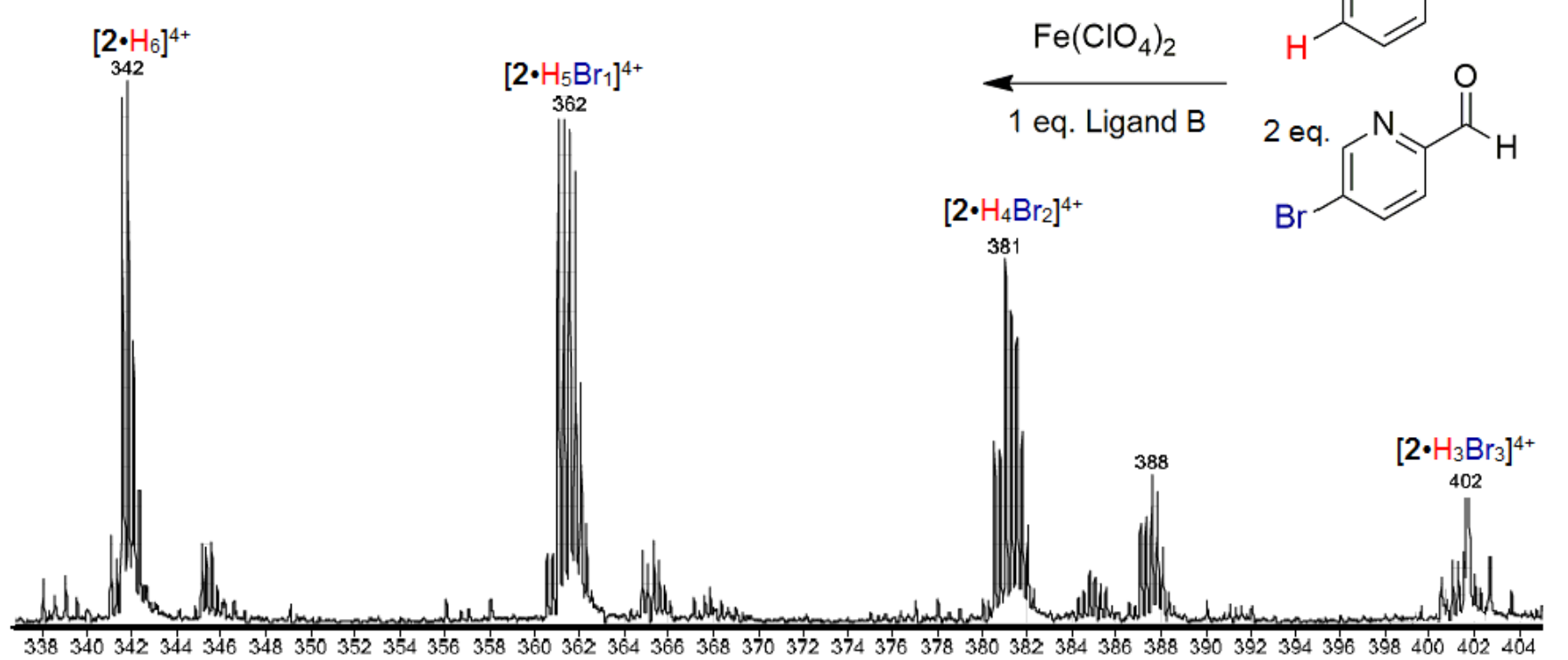

Figure S77. ESI-MS spectrum expansion of product distribution formed upon mixing ligand $\mathbf{B}$ with $\mathrm{Fe}\left(\mathrm{ClO}_{4}\right)_{2}$ and equimolar amounts of formylpyridine $\mathbf{4}$ and bromo-formylpyridine $\mathbf{5}$ (four equivalents total) in $\mathrm{CH}_{3} \mathrm{CN}$ with heating at $55{ }^{\circ} \mathrm{C}$ for $12 \mathrm{~h}$. Peaks for the observed possible combinations of $\left[\left(\mathbf{2} \cdot \mathrm{H}_{\mathrm{x}} \mathrm{Br}_{\mathrm{y}}\right)\right]^{4+}$ ions are shown $\left(\mathrm{CH}_{3} \mathrm{CN}\right)$. 

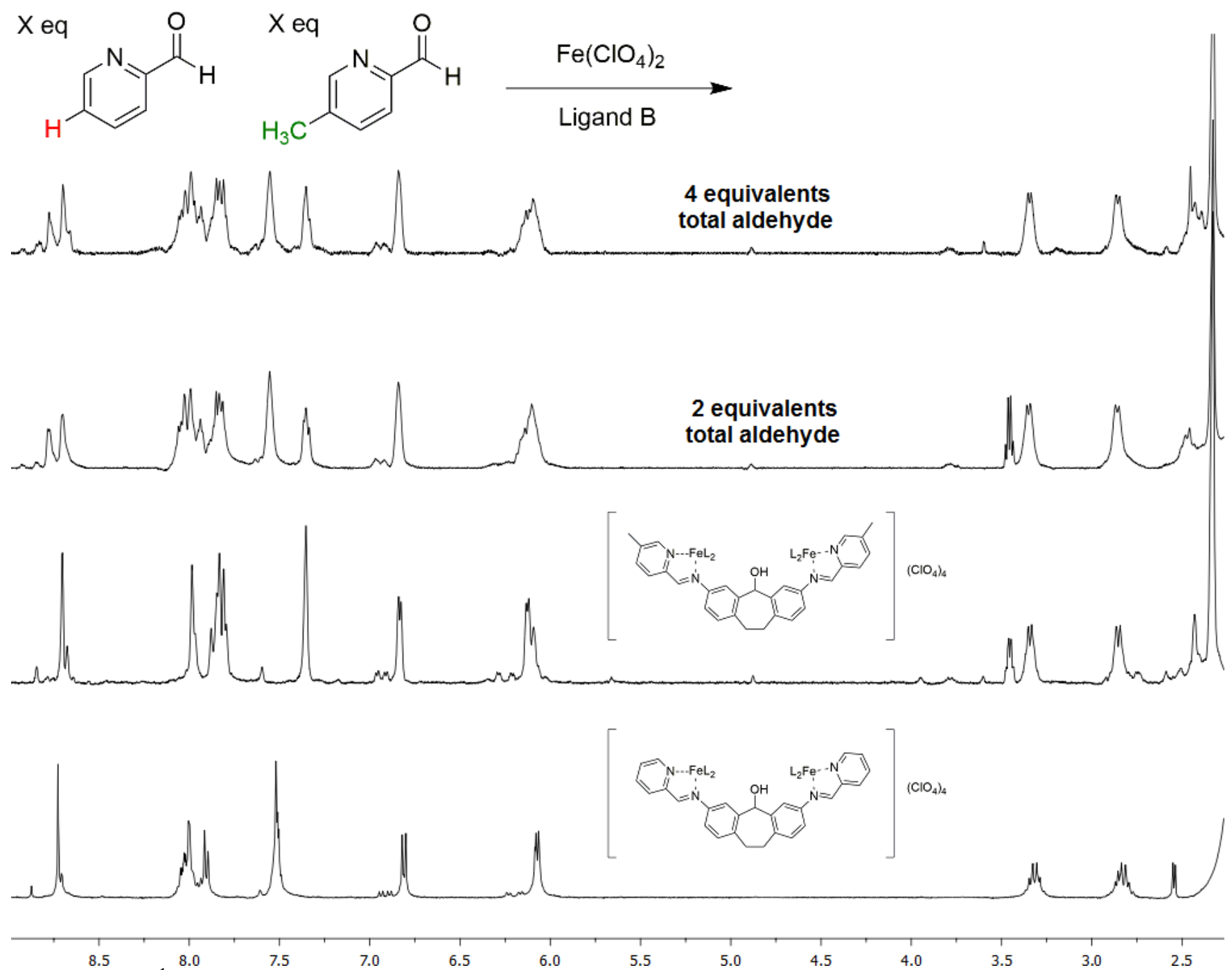

Figure S78. ${ }^{1} \mathrm{H}$ NMR spectrum of product distributions formed upon mixing ligand $\mathbf{B}$ with $\mathrm{Fe}\left(\mathrm{ClO}_{4}\right)_{2}$ and equimolar amounts of formylpyridine $\mathbf{4}$ and methyl-formylpyridine $\mathbf{6}$ (two equivalents and four equivalents total) in $\mathrm{CH}_{3} \mathrm{CN}$ with heating at $55^{\circ} \mathrm{C}$ for $12 \mathrm{~h}\left(\mathrm{CD}_{3} \mathrm{CN}, 500 \mathrm{MHz}\right.$, spectrum obtained at 298 $\mathrm{K})$. 


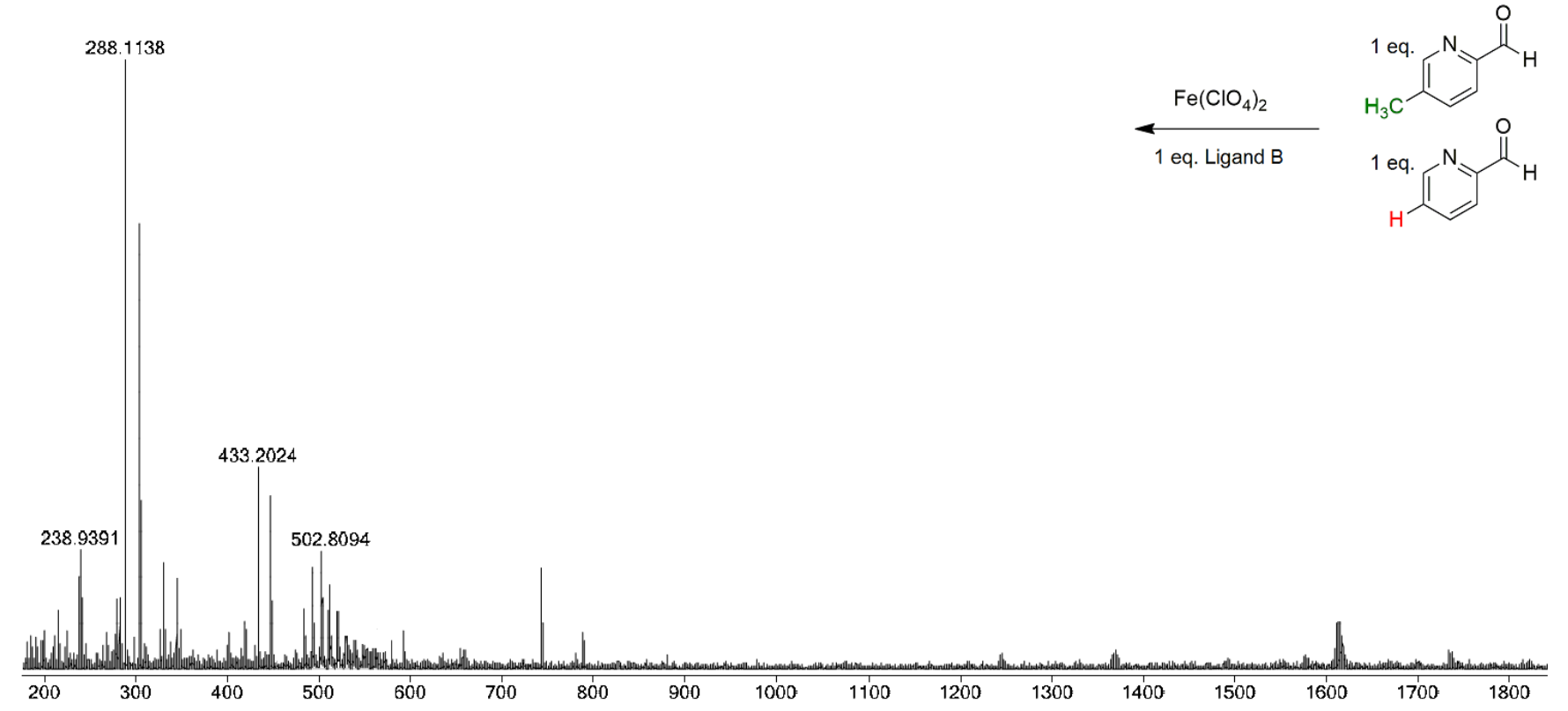

Figure S79. Full ESI-MS spectrum of product distribution formed upon mixing ligand B with $\mathrm{Fe}\left(\mathrm{ClO}_{4}\right)_{2}$ and equimolar amounts of formylpyridine 4 and methyl-formylpyridine 6 (two equivalents total) in $\mathrm{CH}_{3} \mathrm{CN}$ with heating at $55^{\circ} \mathrm{C}$ for $12 \mathrm{~h}\left(\mathrm{CH}_{3} \mathrm{CN}\right)$.

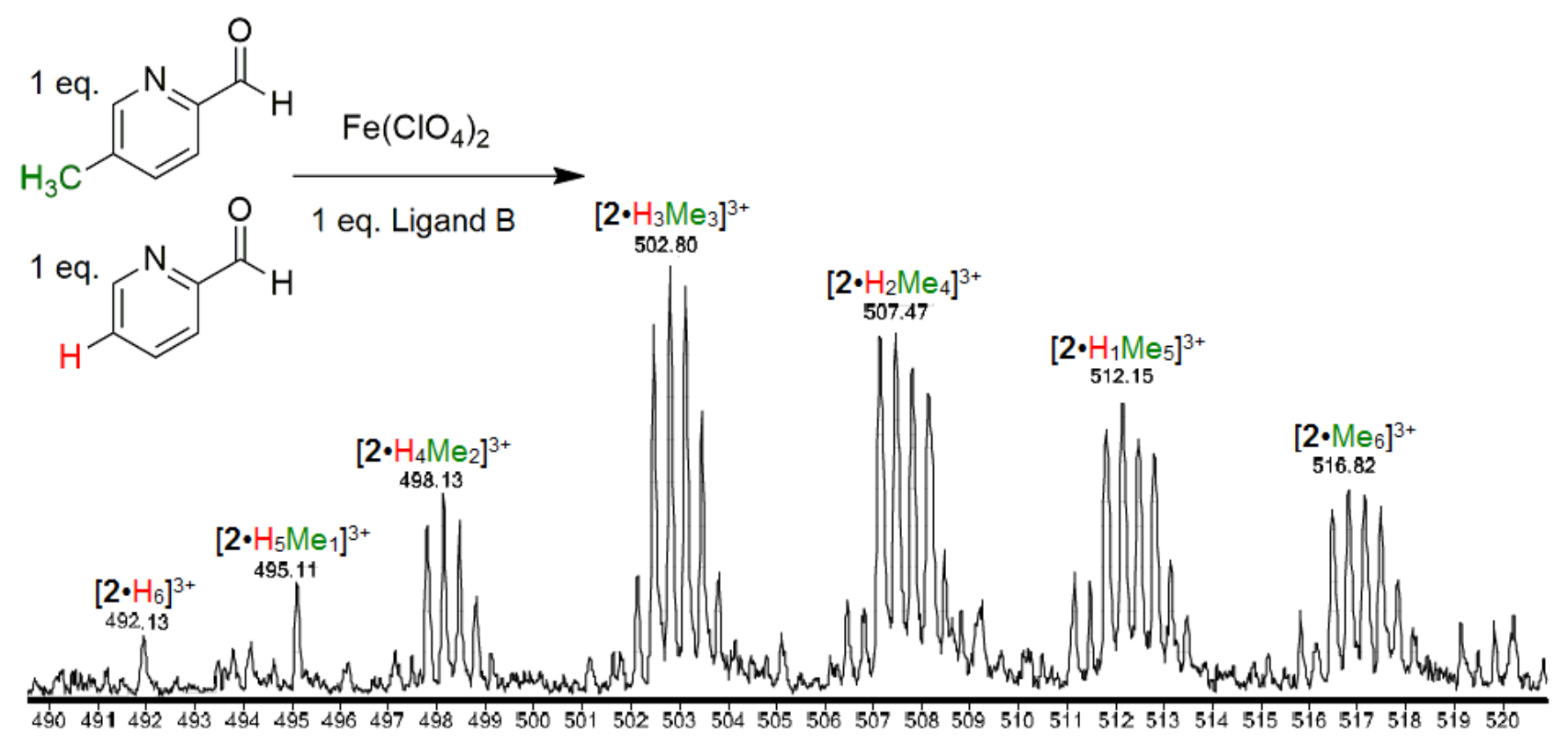

Figure S80. ESI-MS spectrum expansion of product distribution formed upon mixing ligand $\mathbf{B}$ with $\mathrm{Fe}\left(\mathrm{ClO}_{4}\right)_{2}$ and equimolar amounts of formylpyridine $\mathbf{4}$ and methyl-formylpyridine $\mathbf{6}$ (two equivalents total) in $\mathrm{CH}_{3} \mathrm{CN}$ with heating at $55{ }^{\circ} \mathrm{C}$ for $12 \mathrm{~h}$. Peaks for the observed possible combinations of $\left[\left(2 \cdot \mathrm{H}_{\mathrm{x}} \mathrm{Me}_{\mathrm{y}}\right) \cdot \mathrm{ClO}_{4}\right]^{3+}$ ions are shown $\left(\mathrm{CH}_{3} \mathrm{CN}\right)$. 

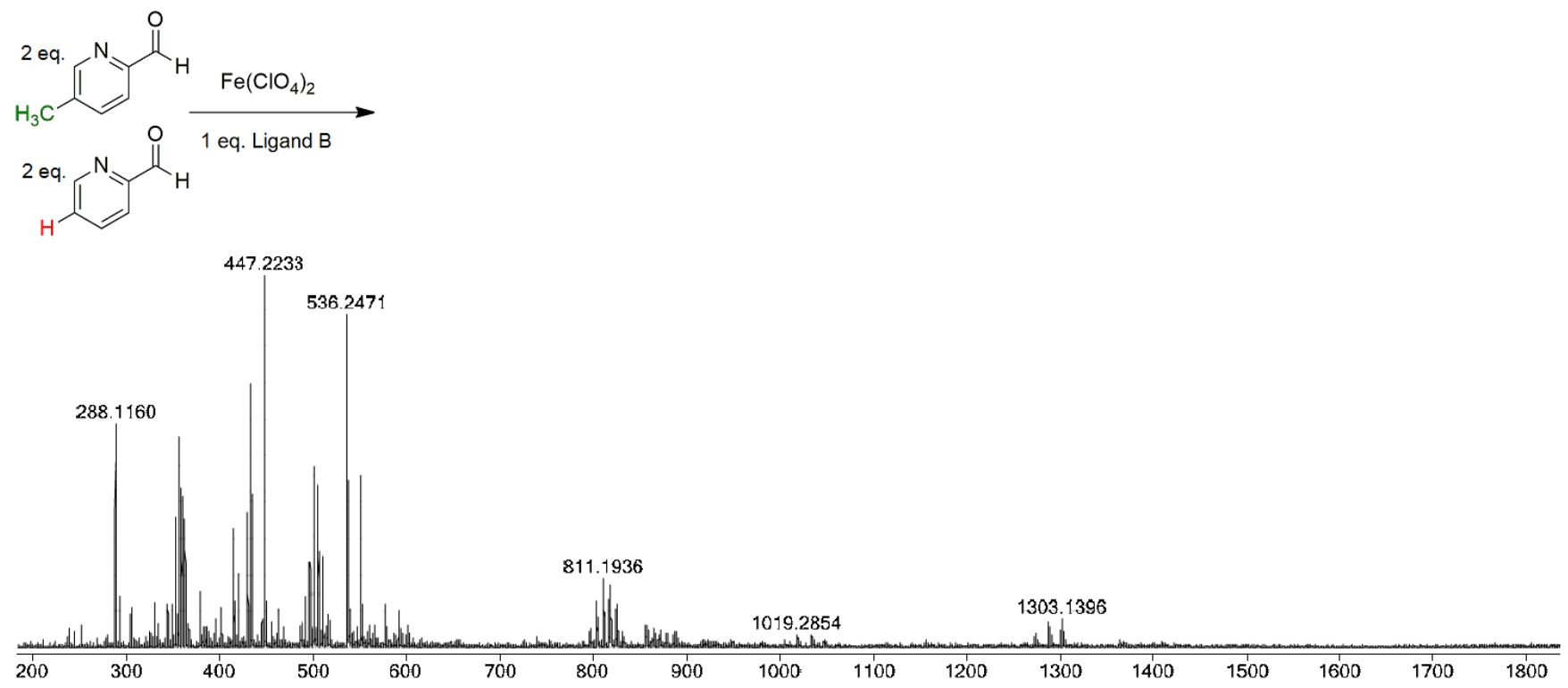

Figure S81. Full ESI-MS spectrum of product distribution formed upon mixing ligand $\mathbf{B}$ with $\mathrm{Fe}\left(\mathrm{ClO}_{4}\right)_{2}$ and equimolar amounts of formylpyridine $\mathbf{4}$ and methyl-formylpyridine $\mathbf{6}$ (four equivalents total) in $\mathrm{CH}_{3} \mathrm{CN}$ with heating at $55^{\circ} \mathrm{C}$ for $12 \mathrm{~h}\left(\mathrm{CH}_{3} \mathrm{CN}\right)$.<smiles>Cc1ccc(C=O)nc1</smiles>

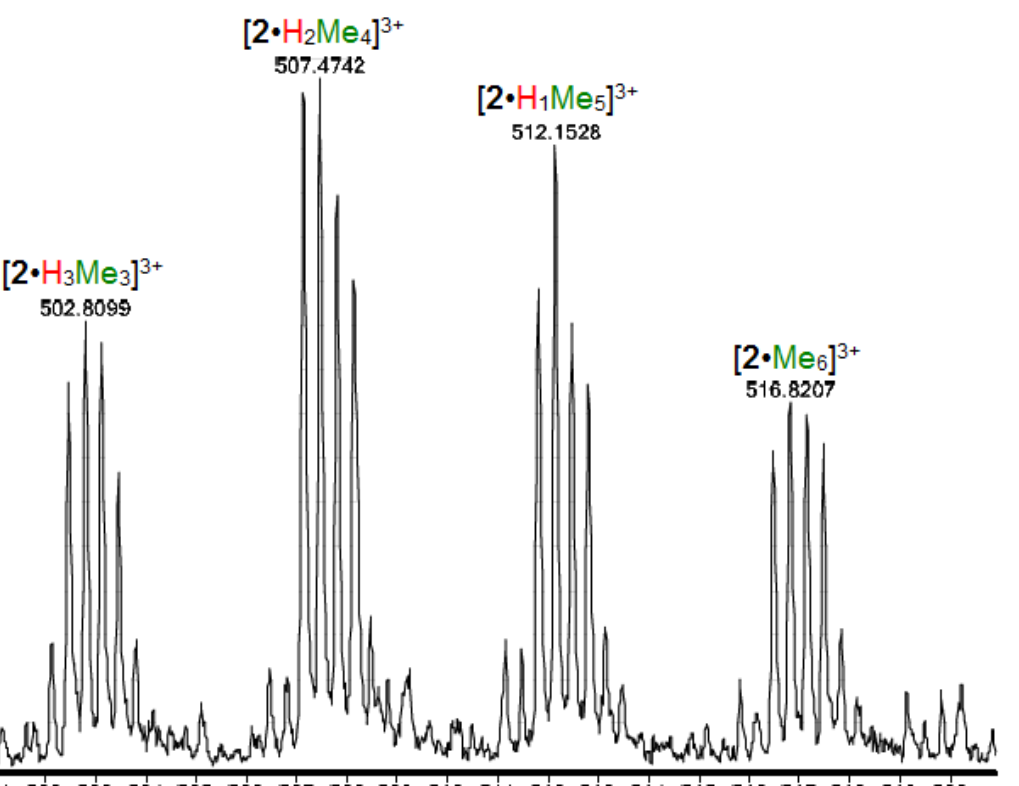

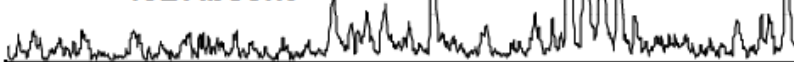

$\left[2 \cdot \mathrm{H}_{6}\right]^{3+}$

$\left[2 \cdot \mathrm{H}_{5} \mathrm{Me}_{1}\right]^{3+}$

498.1345

$487488489490491492493494495496497498499500501502503504505 \quad 506 \quad 507$

Counts (\%) v6. Mass-to-Charge $(\mathrm{m} / \mathrm{z})$

Figure S82. ESI-MS spectrum expansion of product distribution formed upon mixing ligand $\mathbf{B}$ with $\mathrm{Fe}\left(\mathrm{ClO}_{4}\right)_{2}$ and equimolar amounts of formylpyridine $\mathbf{4}$ and methyl-formylpyridine $\mathbf{6}$ (four equivalents total) in $\mathrm{CH}_{3} \mathrm{CN}$ with heating at $55{ }^{\circ} \mathrm{C}$ for $12 \mathrm{~h}$. Peaks for the observed possible combinations of $\left[\left(\mathbf{2} \cdot \mathrm{H}_{\mathrm{x}} \mathrm{Me}_{\mathrm{y}}\right) \cdot \mathrm{ClO}_{4}\right]^{3+}$ ions are shown $\left(\mathrm{CH}_{3} \mathrm{CN}\right)$. 


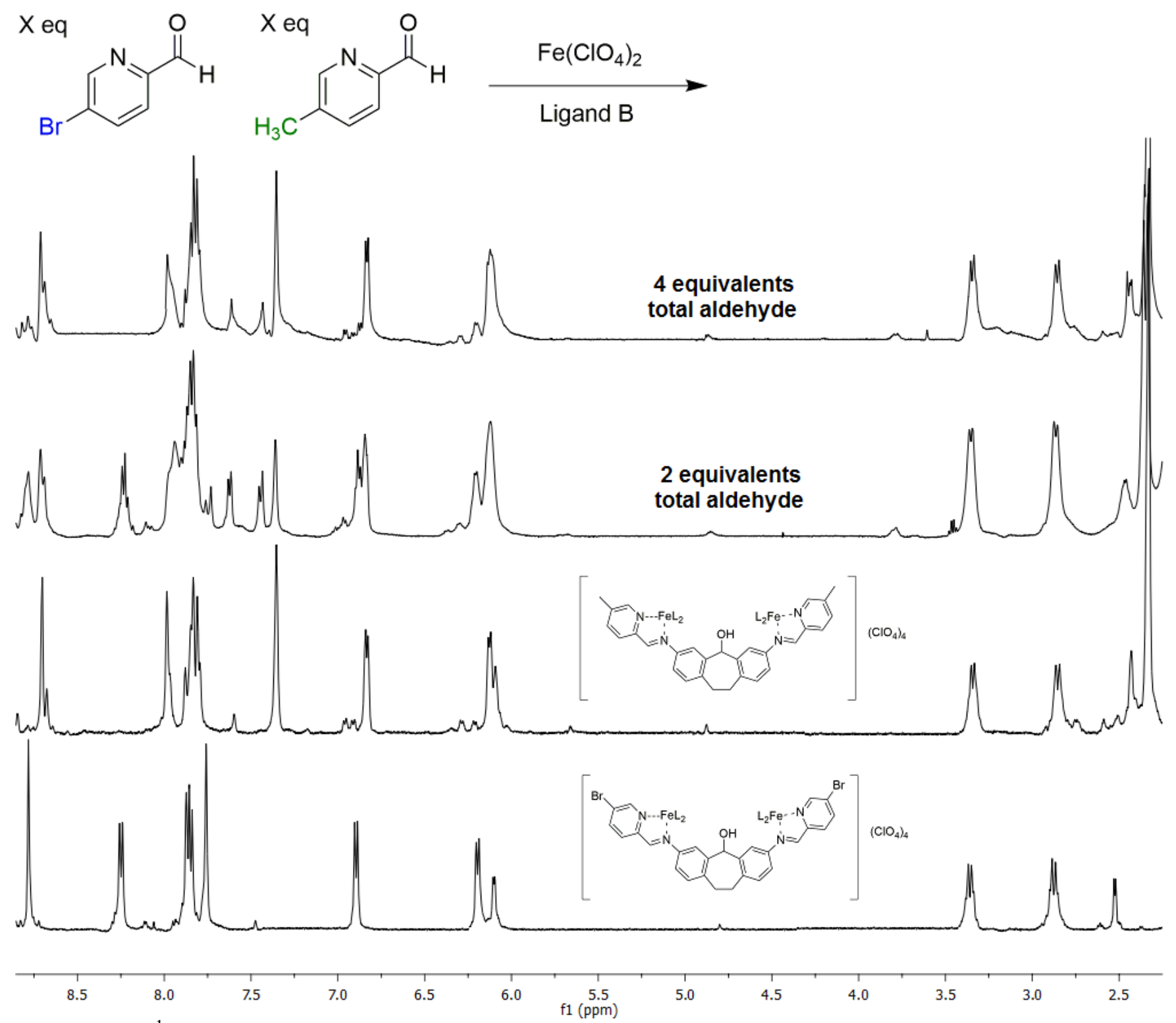

Figure S83. ${ }^{1} \mathrm{H}$ NMR spectrum of product distributions formed upon mixing ligand $\mathbf{B}$ with $\mathrm{Fe}\left(\mathrm{ClO}_{4}\right)_{2}$ and equimolar amounts of bromo-formylpyridine $\mathbf{5}$ and methyl-formylpyridine $\mathbf{6}$ (two equivalents and four equivalents total) in $\mathrm{CH}_{3} \mathrm{CN}$ with heating at $55^{\circ} \mathrm{C}$ for $12 \mathrm{~h}\left(\mathrm{CD}_{3} \mathrm{CN}, 500 \mathrm{MHz}\right.$, spectra taken at $\left.298 \mathrm{~K}\right)$. 


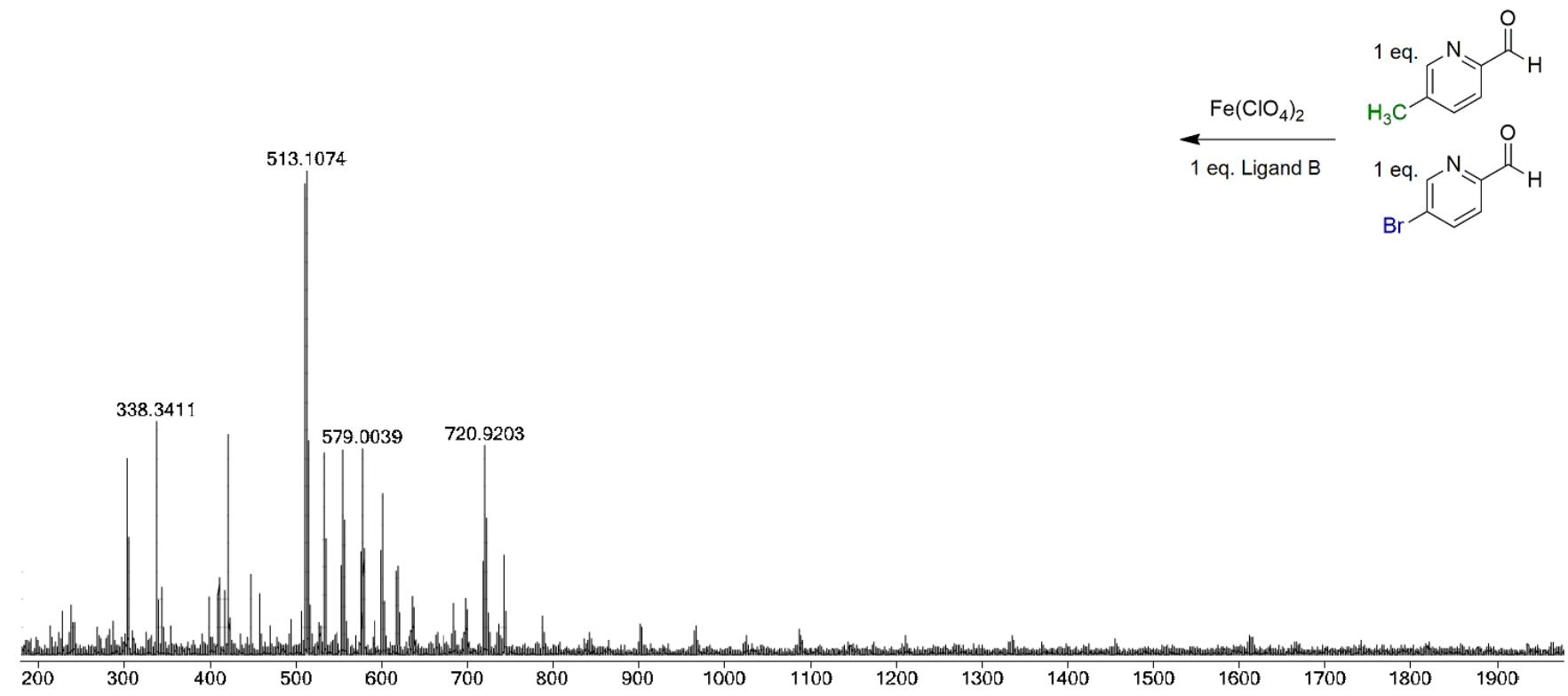

Figure S84. Full ESI-MS spectrum of product distribution formed upon mixing ligand $\mathbf{B}$ with $\mathrm{Fe}\left(\mathrm{ClO}_{4}\right)_{2}$ and equimolar amounts of bromo-formylpyridine $\mathbf{5}$ and methyl-formylpyridine $\mathbf{6}$ (two equivalents total) in $\mathrm{CH}_{3} \mathrm{CN}$ with heating at $55^{\circ} \mathrm{C}$ for $12 \mathrm{~h}\left(\mathrm{CH}_{3} \mathrm{CN}\right)$.

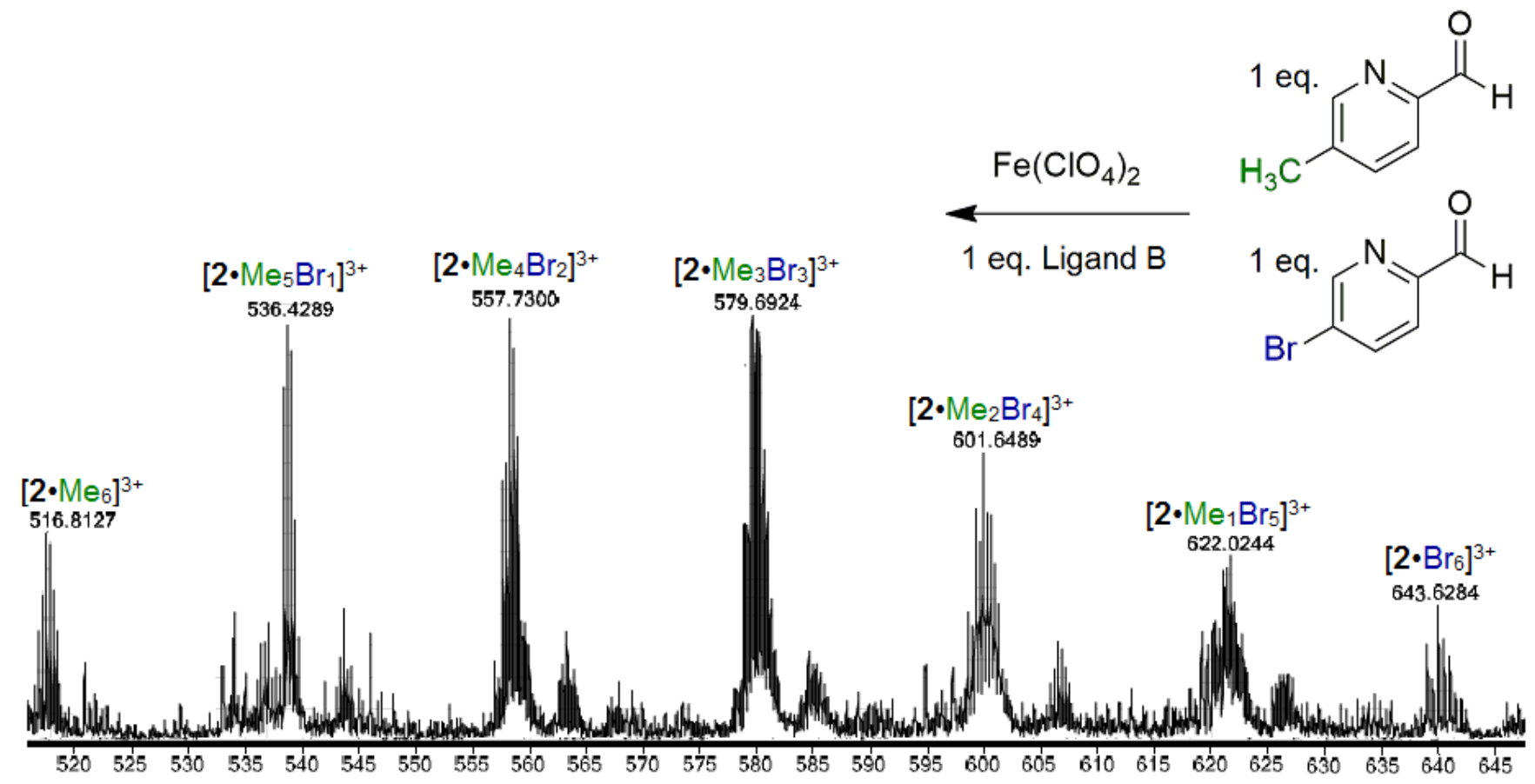

Figure S85. ESI-MS spectrum expansion of product distribution formed upon mixing ligand $\mathbf{B}$ with $\mathrm{Fe}\left(\mathrm{ClO}_{4}\right)_{2}$ and equimolar amounts of bromo-formylpyridine 5 and methyl-formylpyridine $\mathbf{6}$ (two equivalents total) in $\mathrm{CH}_{3} \mathrm{CN}$ with heating at $55{ }^{\circ} \mathrm{C}$ for $12 \mathrm{~h}$. Peaks for the observed possible combinations of $\left[\left(\mathbf{2} \cdot \mathrm{Me}_{\mathrm{x}} \mathrm{Br}_{\mathrm{y}}\right) \cdot \mathrm{ClO}_{4}\right]^{3+}$ ions are shown $\left(\mathrm{CH}_{3} \mathrm{CN}\right)$. 


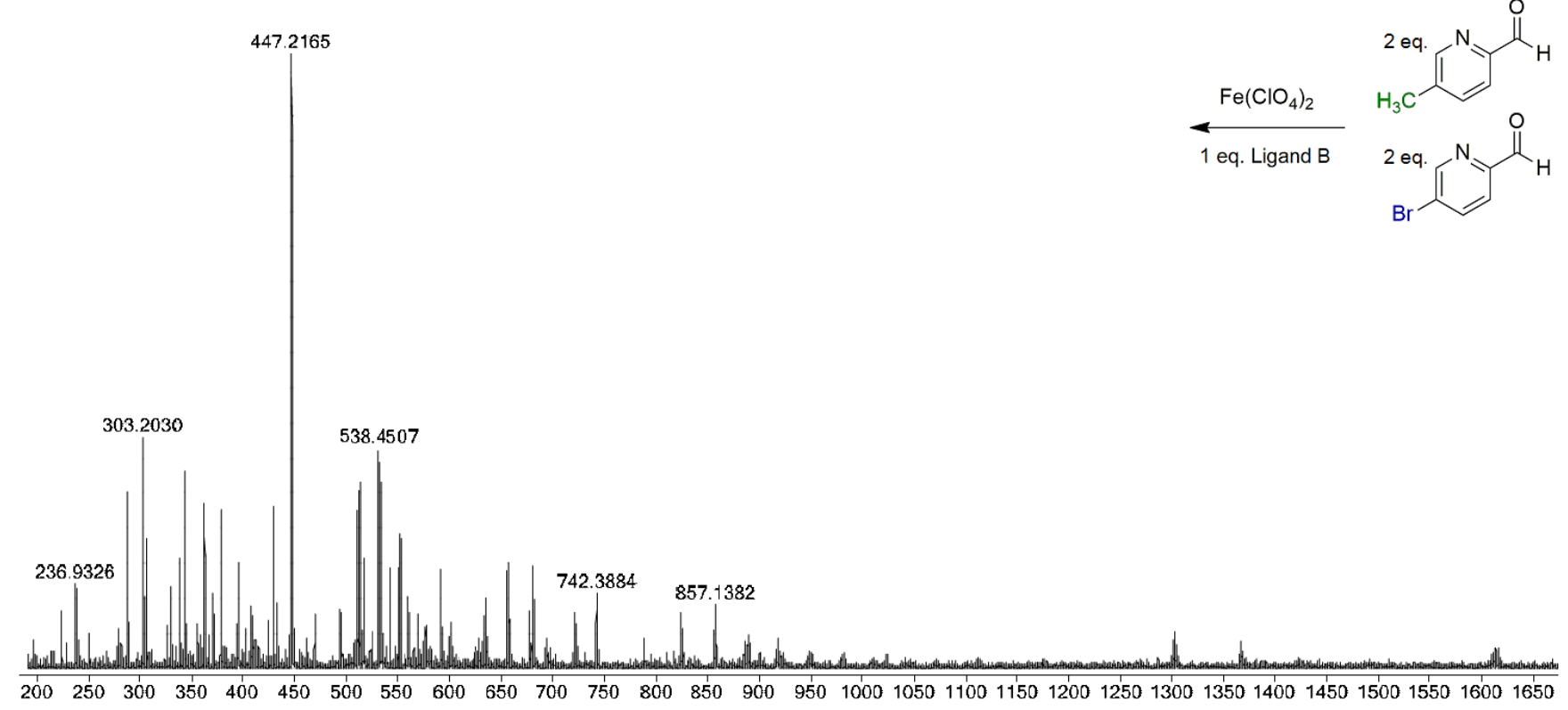

Figure S86. Full ESI-MS spectrum of product distribution formed upon mixing of ligand $\mathbf{B}$ with $\mathrm{Fe}\left(\mathrm{ClO}_{4}\right)_{2}$ and equimolar amounts of bromo-formylpyridine $\mathbf{5}$ and methyl-formylpyridine $\mathbf{6}$ (four equivalents total) in $\mathrm{CH}_{3} \mathrm{CN}$ with heating at $55^{\circ} \mathrm{C}$ for $12 \mathrm{~h}\left(\mathrm{CH}_{3} \mathrm{CN}\right)$.

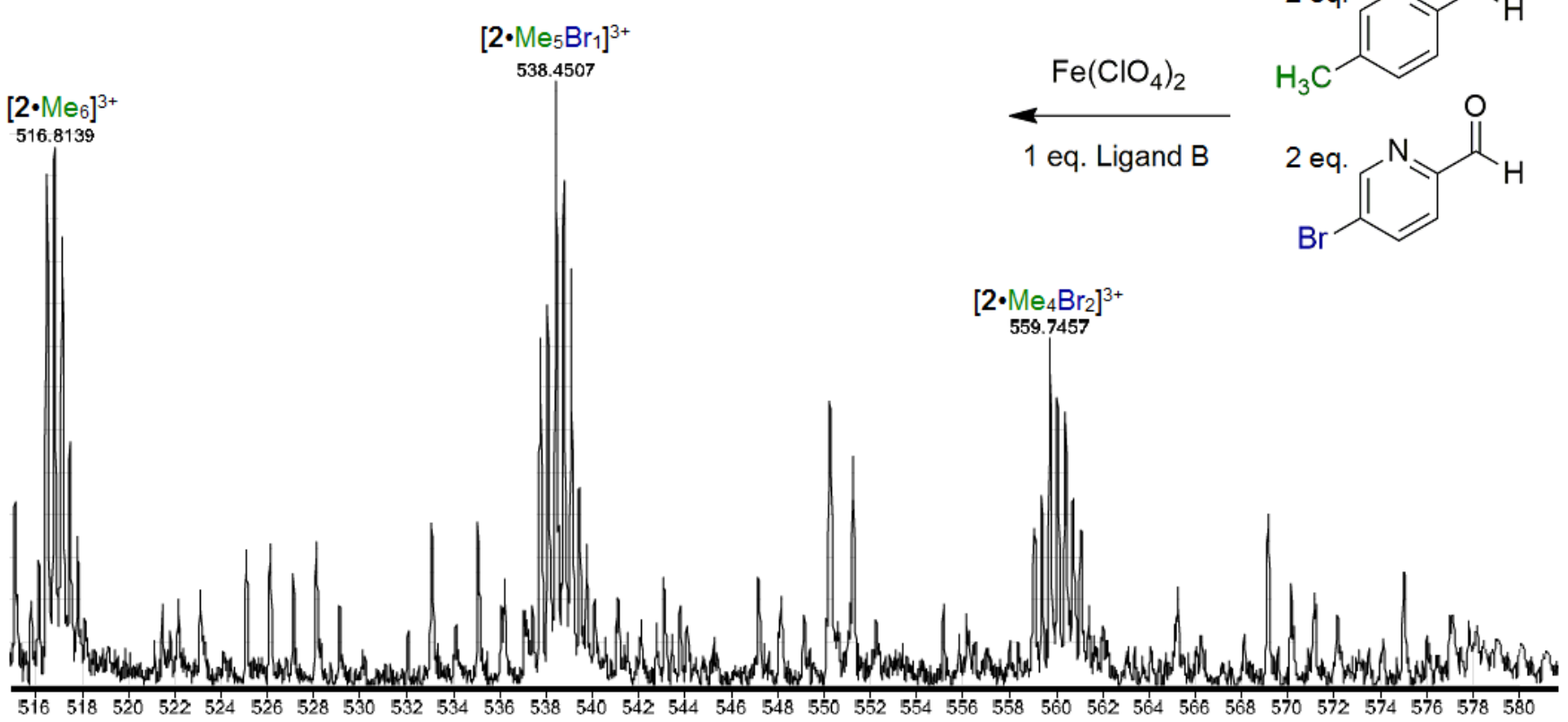

Figure S87. ESI-MS spectrum expansion of product distribution formed upon mixing of ligand $\mathbf{B}$ with $\mathrm{Fe}\left(\mathrm{ClO}_{4}\right)_{2}$ and equimolar amounts of bromo-formylpyridine 5 and methyl-formylpyridine $\mathbf{6}$ (four equivalents total) in $\mathrm{CH}_{3} \mathrm{CN}$ with heating at $55{ }^{\circ} \mathrm{C}$ for $12 \mathrm{~h}$. Peaks for the observed possible combinations of $\left[\left(2 \cdot \mathrm{Me}_{\mathrm{x}} \mathrm{Br}_{\mathrm{y}}\right) \cdot \mathrm{ClO}_{4}\right]^{3+}$ ions are shown $\left(\mathrm{CH}_{3} \mathrm{CN}\right)$. 


\section{4c. Aldehyde Terminus Mixing with Suberenone Ligand C}
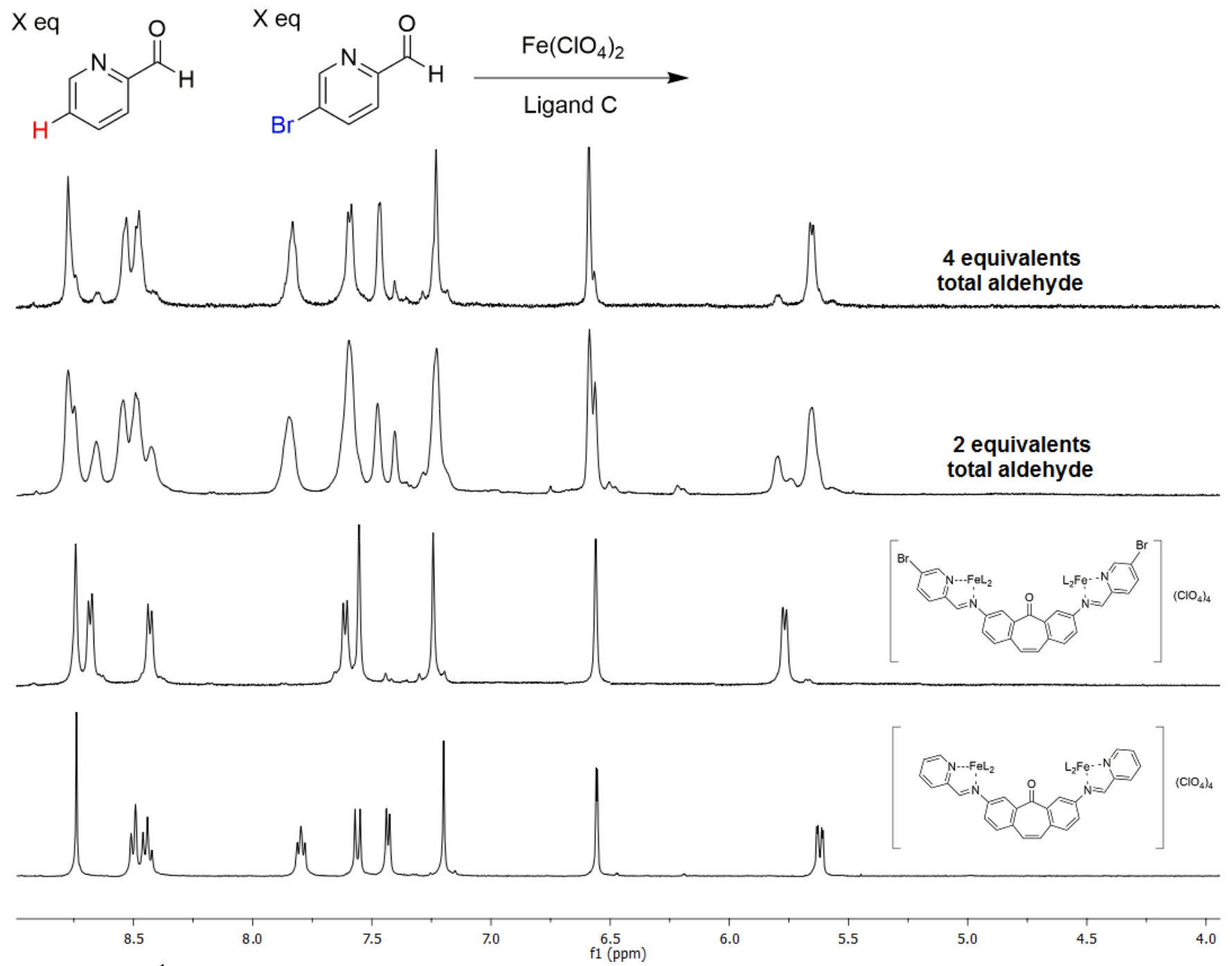

Figure S88. ${ }^{1} \mathrm{H}$ NMR spectrum of product distributions formed upon mixing ligand $\mathbf{C}$ with $\mathrm{Fe}\left(\mathrm{ClO}_{4}\right)_{2}$ and equimolar amounts of formylpyridine 4 and bromo-formylpyridine 5 (two equivalents and four equivalents total) in $\mathrm{CH}_{3} \mathrm{CN}$ with heating at $55^{\circ} \mathrm{C}$ for $12 \mathrm{~h}\left(\mathrm{CD}_{3} \mathrm{CN}, 500 \mathrm{MHz}, 298 \mathrm{~K}\right)$. 


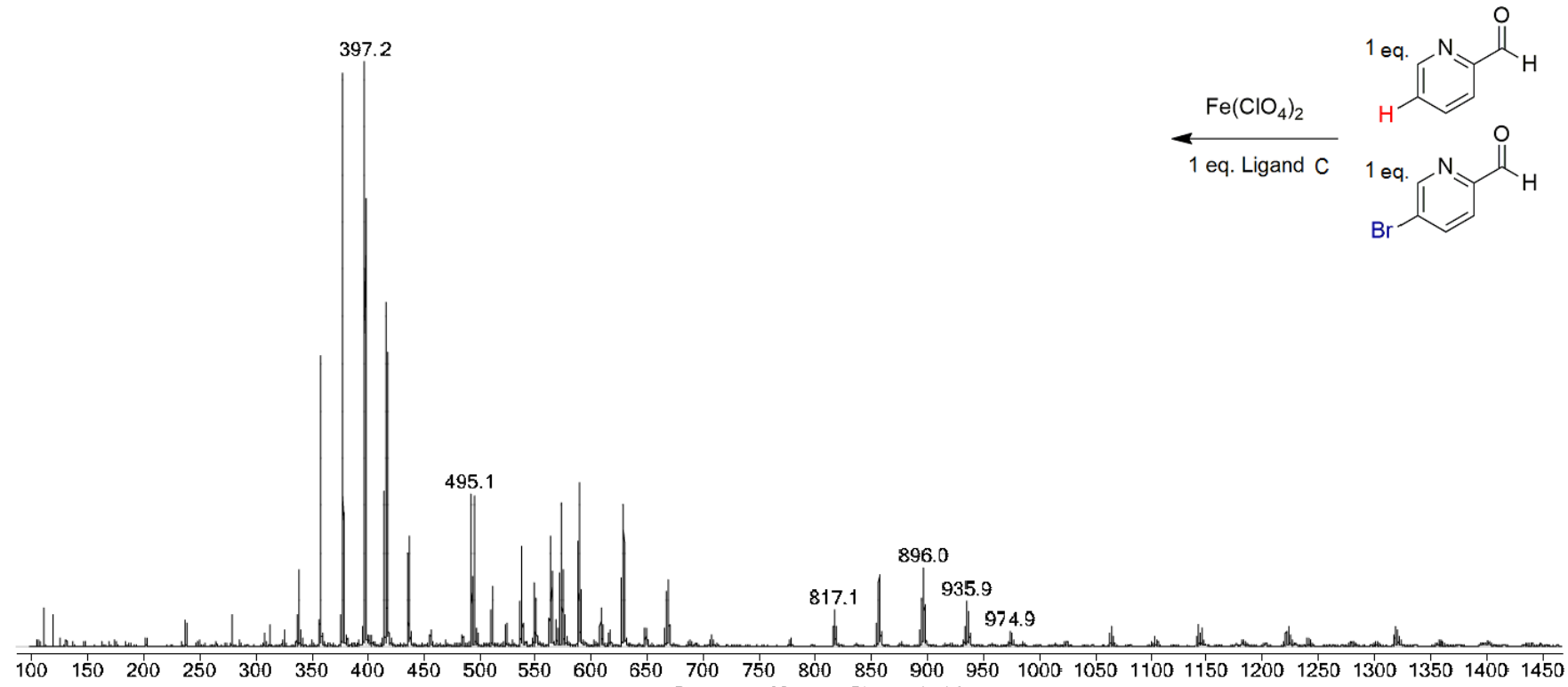

Figure S89. Full ESI-MS spectrum of product distribution formed upon mixing of ligand $\mathbf{C}$ with $\mathrm{Fe}\left(\mathrm{ClO}_{4}\right)_{2}$ and equimolar amounts of formylpyridine 4 and bromo-formylpyridine 5 (two equivalents total) in $\mathrm{CH}_{3} \mathrm{CN}$ with heating at $55^{\circ} \mathrm{C}$ for $12 \mathrm{~h}\left(\mathrm{CH}_{3} \mathrm{CN}\right)$.

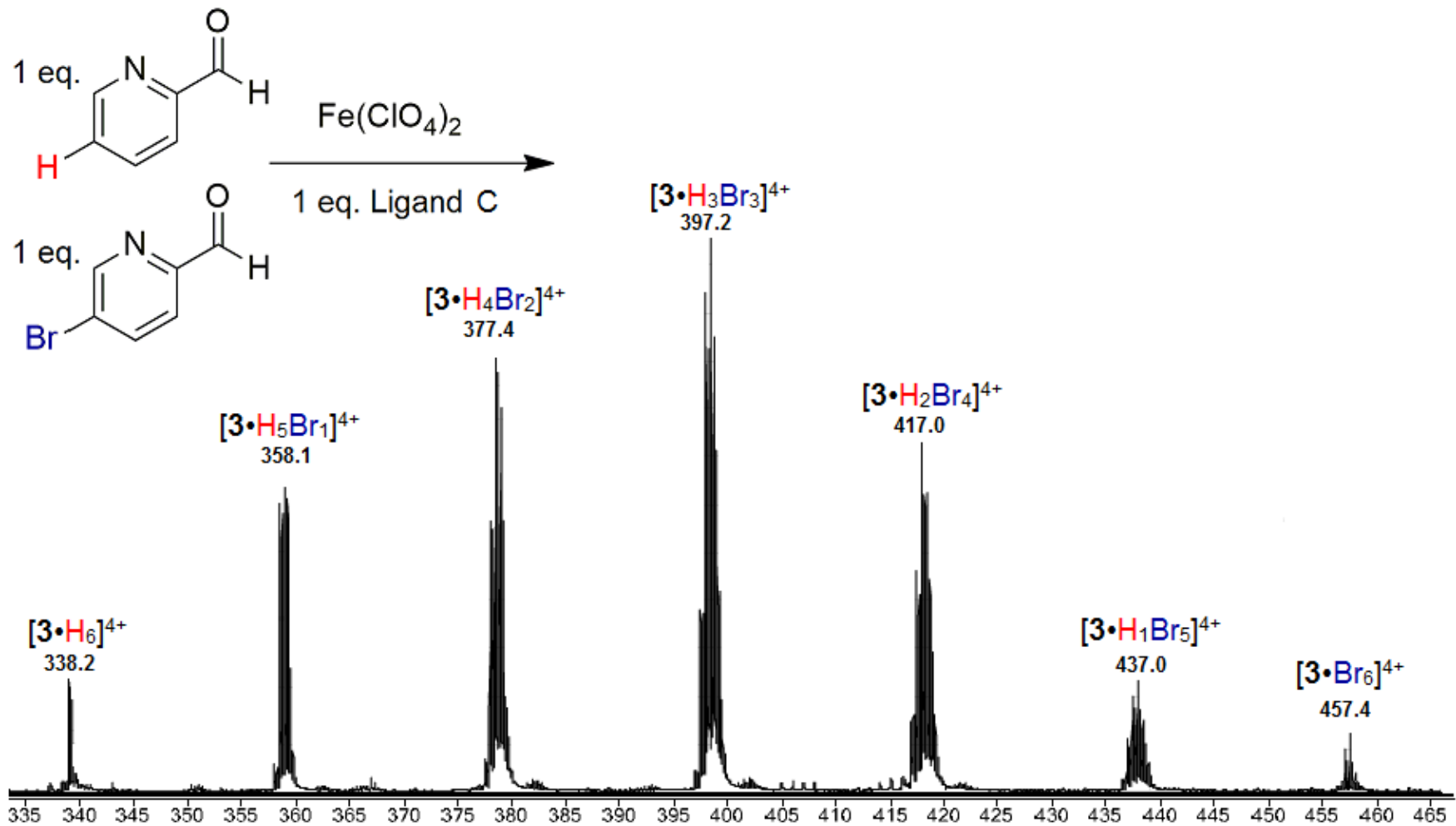

Figure S90. ESI-MS spectrum expansion of product distribution formed upon mixing of ligand $\mathbf{C}$ with $\mathrm{Fe}\left(\mathrm{ClO}_{4}\right)_{2}$ and equimolar amounts of formylpyridine 4 and bromo-formylpyridine 5 (two equivalents total) in $\mathrm{CH}_{3} \mathrm{CN}$ with heating at $55^{\circ} \mathrm{C}$ for $12 \mathrm{~h}$. Peaks for the observed possible combinations of $\left[\left(3^{\circ} \mathrm{H}_{\mathrm{x}} \mathrm{Br}_{\mathrm{y}}\right)\right]^{4+}$ ions are shown $\left(\mathrm{CH}_{3} \mathrm{CN}\right)$. 

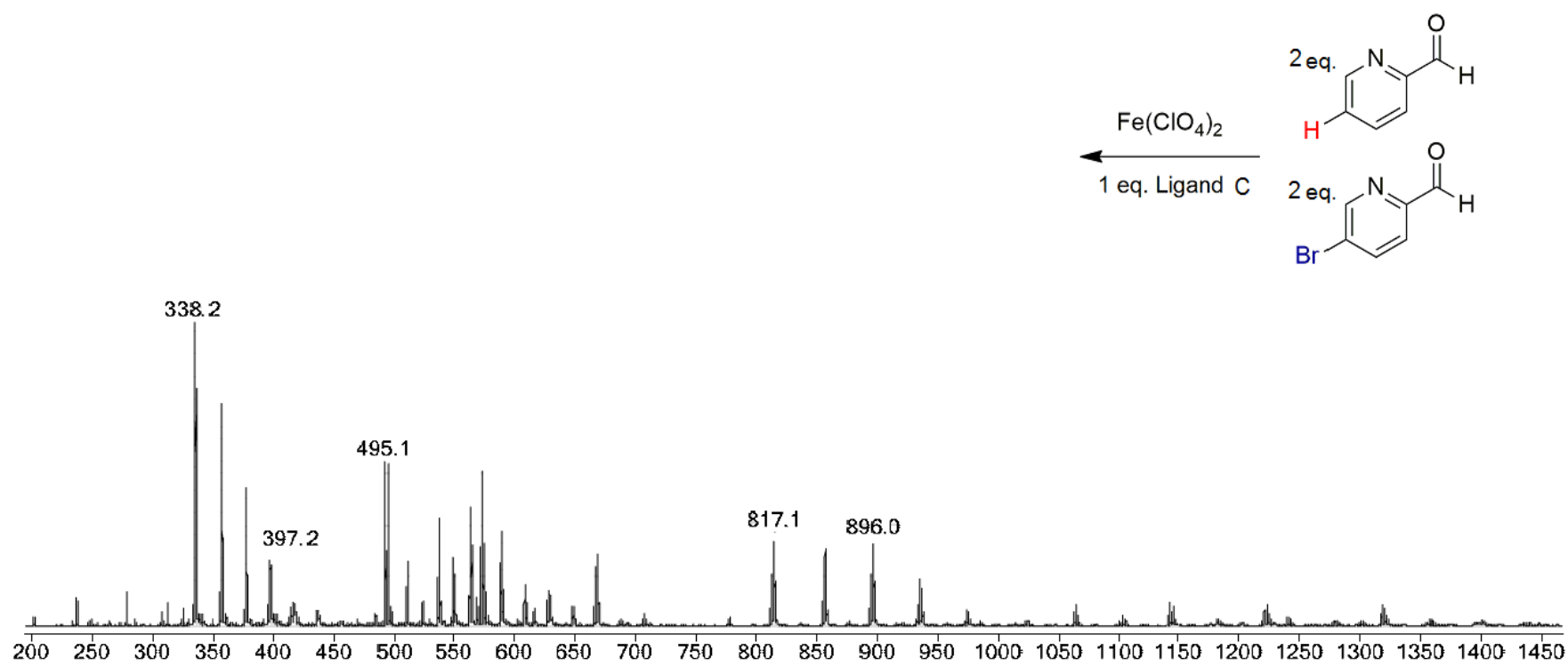

Figure S91. Full ESI-MS spectrum of product distribution formed upon mixing ligand $\mathbf{C}$ with $\mathrm{Fe}\left(\mathrm{ClO}_{4}\right)_{2}$ and equimolar amounts of formylpyridine 4 and bromo-formylpyridine 5 (four equivalents total) in $\mathrm{CH}_{3} \mathrm{CN}$ with heating at $55^{\circ} \mathrm{C}$ for $12 \mathrm{~h}$ shown $\left(\mathrm{CH}_{3} \mathrm{CN}\right)$.

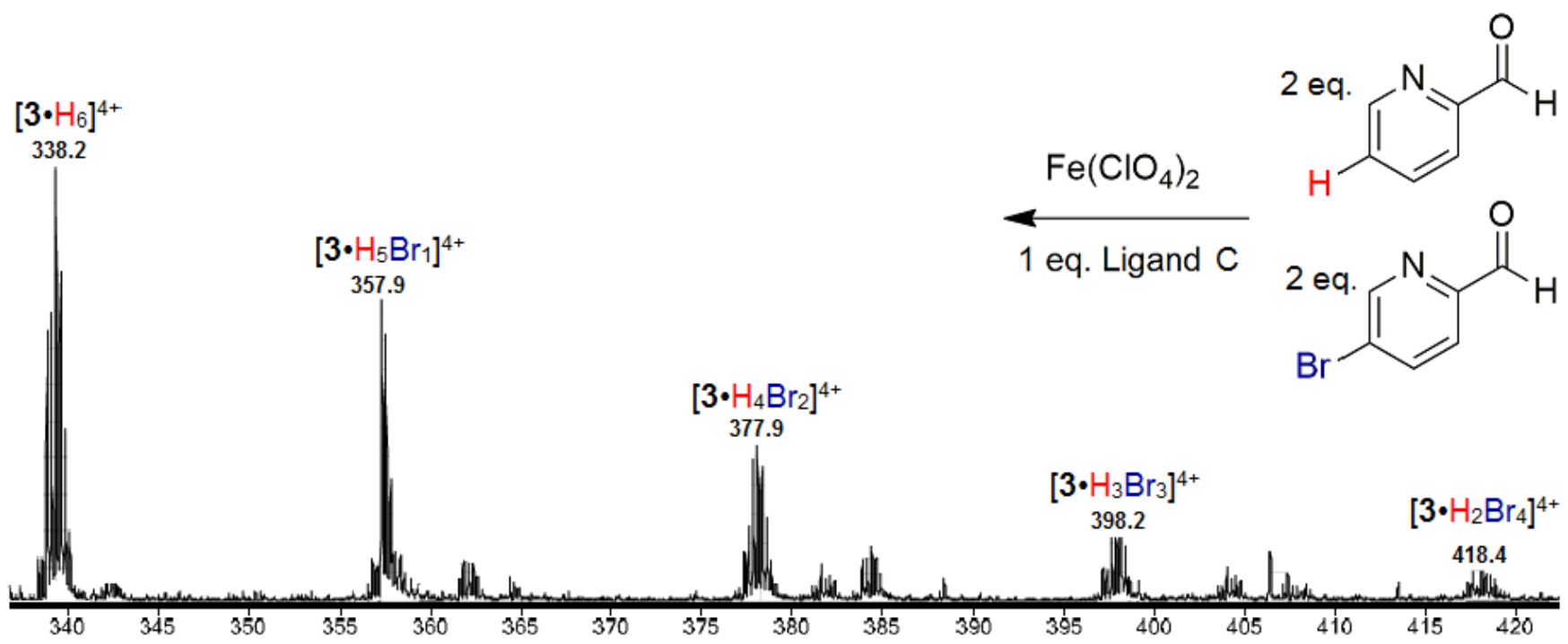

Figure S92. ESI-MS spectrum expansion of product distribution formed upon mixing ligand $\mathbf{C}$ with $\mathrm{Fe}\left(\mathrm{ClO}_{4}\right)_{2}$ and equimolar amounts of formylpyridine $\mathbf{4}$ and bromo-formylpyridine $\mathbf{5}$ (four equivalents total) in $\mathrm{CH}_{3} \mathrm{CN}$ with heating at $55{ }^{\circ} \mathrm{C}$ for $12 \mathrm{~h}$. Peaks for the observed possible combinations of $\left[\left(3 \cdot \mathrm{H}_{\mathrm{x}} \mathrm{Br}_{\mathrm{y}}\right)\right]^{4+}$ ions are shown $\left(\mathrm{CH}_{3} \mathrm{CN}\right)$. 
<smiles></smiles><smiles>CC(=O)OCc1ccc(C)cn1</smiles><smiles>COC(=O)OC(C)(C)C</smiles>

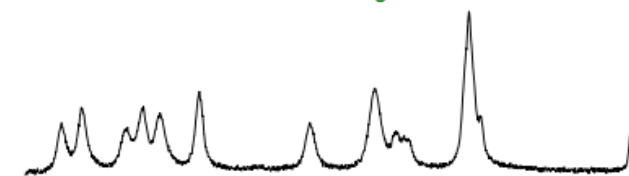
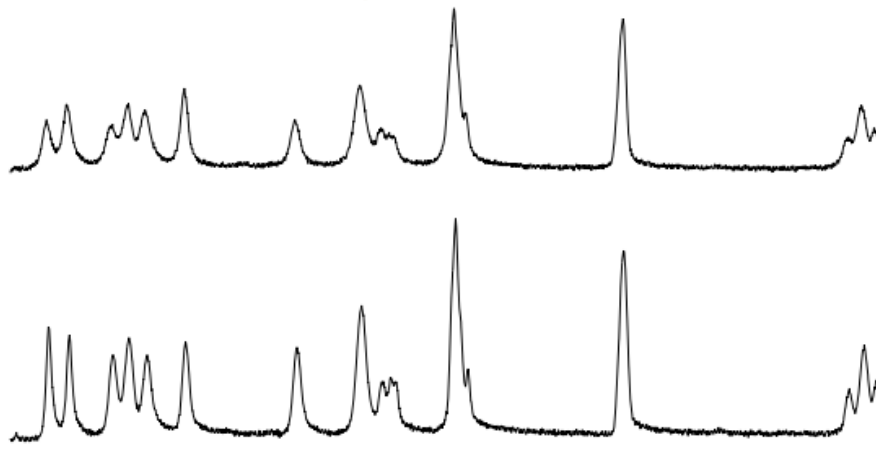

2 equivalents total aldehyde
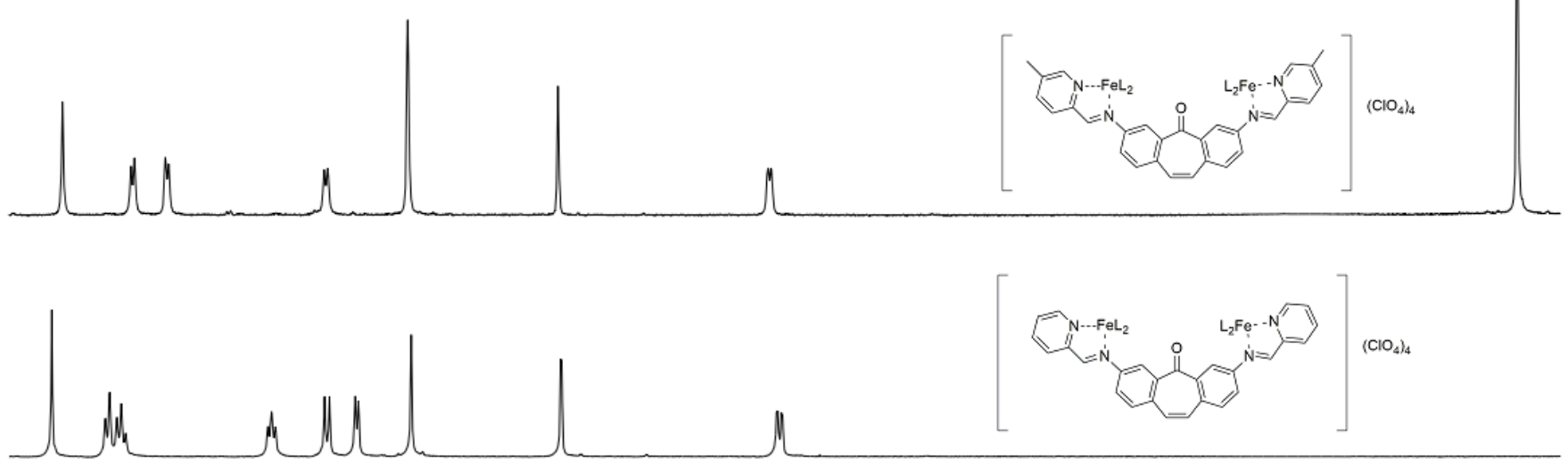
$\begin{array}{lllllllllllllllllllllllllllllllllllllllll}8.8 & 8.6 & 8.4 & 8.2 & 8.0 & 7.8 & 7.6 & 7.4 & 7.2 & 7.0 & 6.8 & 6.6 & 6.4 & 6.2 & 6.0 & 5.8 & 5.6 & 5.4 & 5.2 & 5.0 & 4.8 & 4.6 & 4.4 & 4.2 & 4.0 & 3.8 & 3.6 & 3.4 & 3.2 & 3.0 & 2.8 & 2.6 & 2.4\end{array}$

Figure S93. ${ }^{1} \mathrm{H}$ NMR spectrum of product distributions formed upon mixing ligand $\mathbf{C}$ with $\mathrm{Fe}\left(\mathrm{ClO}_{4}\right)_{2}$ and equimolar amounts of formylpyridine $\mathbf{4}$ and methyl-formylpyridine $\mathbf{6}$ (two equivalents and four equivalents total) in $\mathrm{CH}_{3} \mathrm{CN}$ with heating at $55^{\circ} \mathrm{C}$ for $12 \mathrm{~h}\left(\mathrm{CD}_{3} \mathrm{CN}, 500 \mathrm{MHz}\right.$, spectra taken at $\left.298 \mathrm{~K}\right)$. 


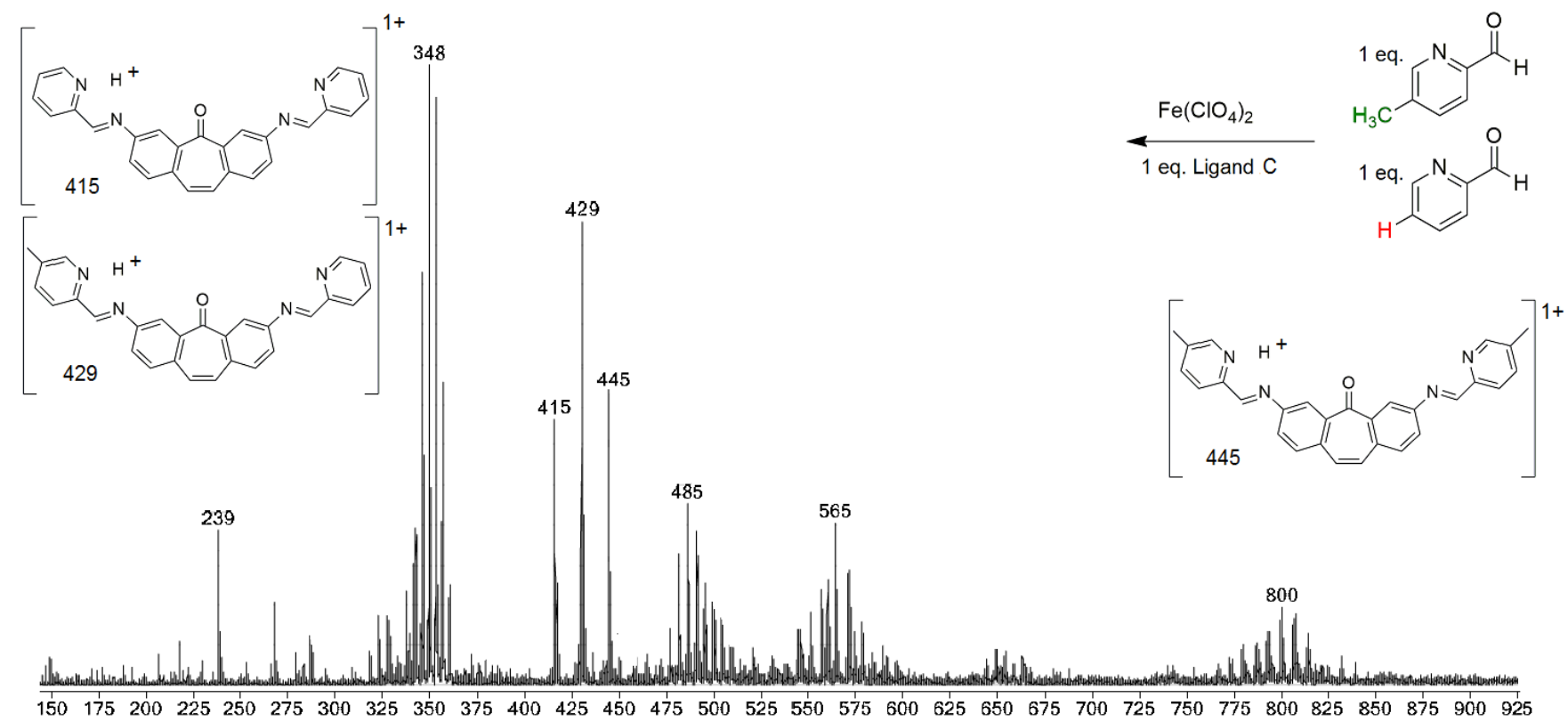

Figure S94. Full ESI-MS spectrum of product distribution formed upon mixing ligand $\mathbf{C}$ with $\mathrm{Fe}\left(\mathrm{ClO}_{4}\right)_{2}$ and equimolar amounts of formylpyridine $\mathbf{4}$ and methyl-formylpyridine $\mathbf{6}$ (two equivalents total) in $\mathrm{CH}_{3} \mathrm{CN}$ with heating at $55^{\circ} \mathrm{C}$ for $12 \mathrm{~h}\left(\mathrm{CH}_{3} \mathrm{CN}\right)$.

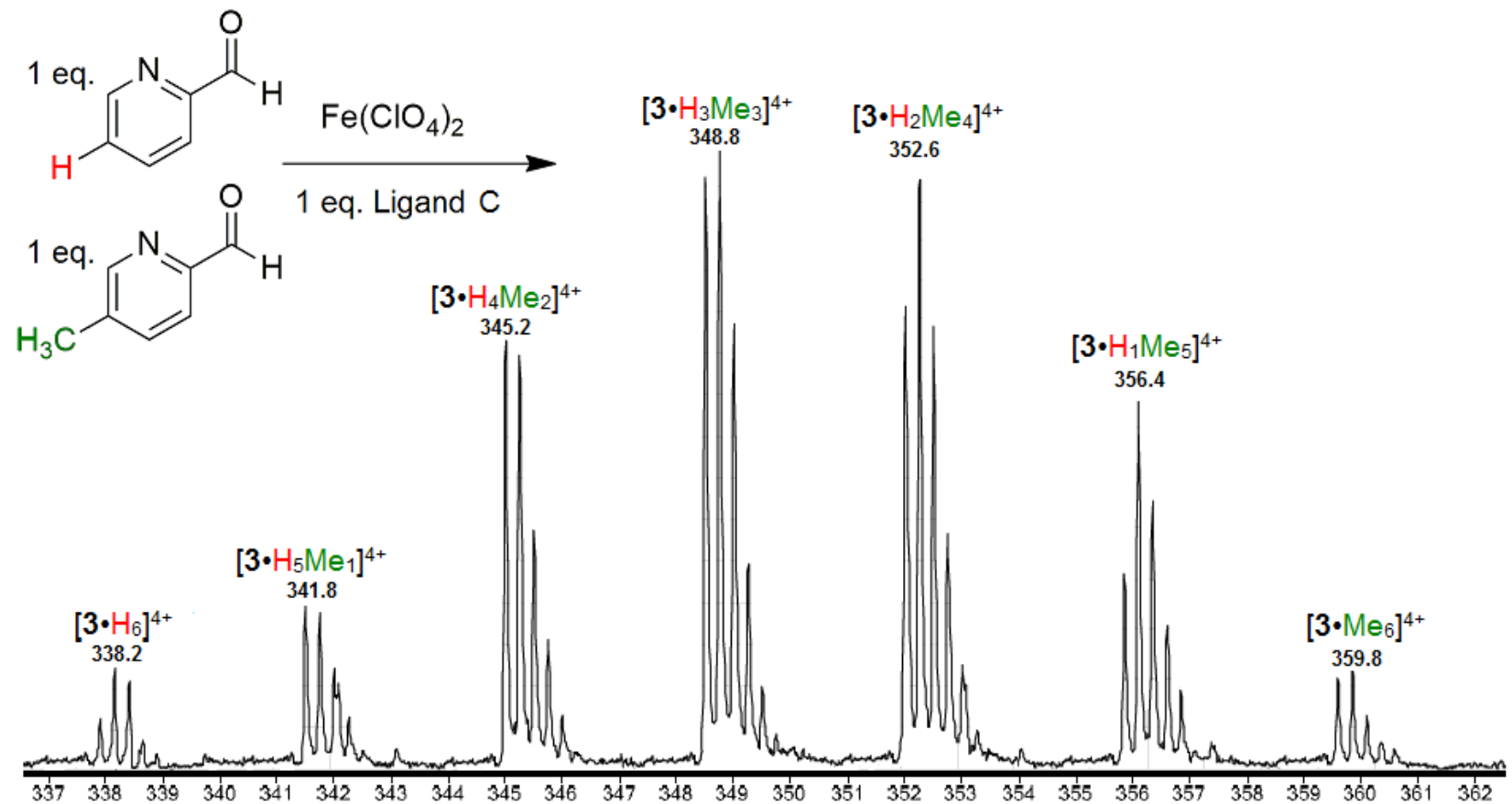

Figure S95. ESI-MS spectrum expansion of product distribution formed upon mixing ligand $\mathbf{C}$ with $\mathrm{Fe}\left(\mathrm{ClO}_{4}\right)_{2}$ and equimolar amounts of formylpyridine $\mathbf{4}$ and methyl-formylpyridine $\mathbf{6}$ (two equivalents total) in $\mathrm{CH}_{3} \mathrm{CN}$ with heating at $55{ }^{\circ} \mathrm{C}$ for $12 \mathrm{~h}$. Peaks for the observed possible combinations of $\left[\left(3 \cdot \mathrm{H}_{\mathrm{x}} \mathrm{Me}_{\mathrm{y}}\right)\right]^{4+}$ ions are shown $\left(\mathrm{CH}_{3} \mathrm{CN}\right)$. 


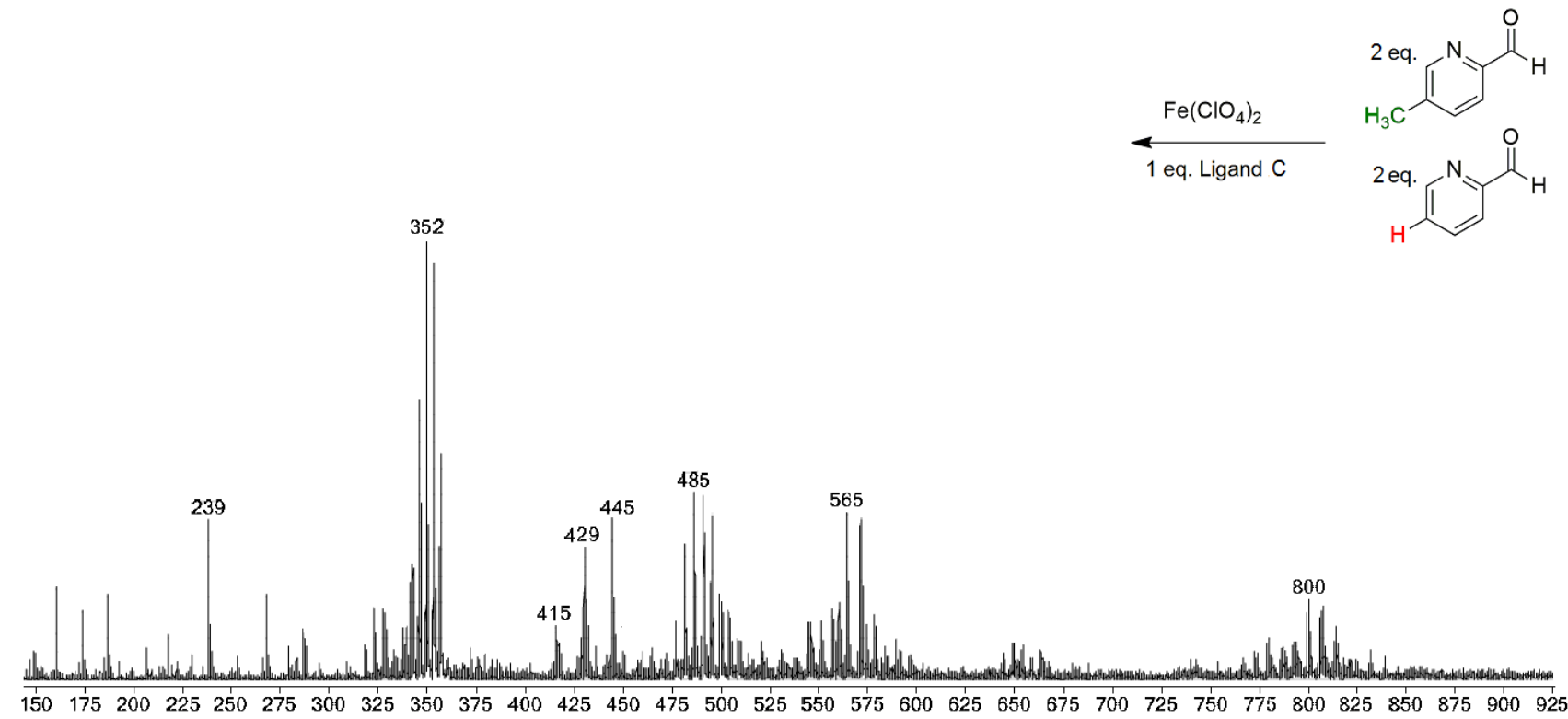

Figure S96. ESI-MS spectrum expansion of product distribution formed upon mixing ligand $\mathbf{C}$ with $\mathrm{Fe}\left(\mathrm{ClO}_{4}\right)_{2}$ and equimolar amounts of formylpyridine $\mathbf{4}$ and methyl-formylpyridine $\mathbf{6}$ (four equivalents total) in $\mathrm{CH}_{3} \mathrm{CN}$ with heating at $55^{\circ} \mathrm{C}$ for $12 \mathrm{~h}\left(\mathrm{CH}_{3} \mathrm{CN}\right)$.

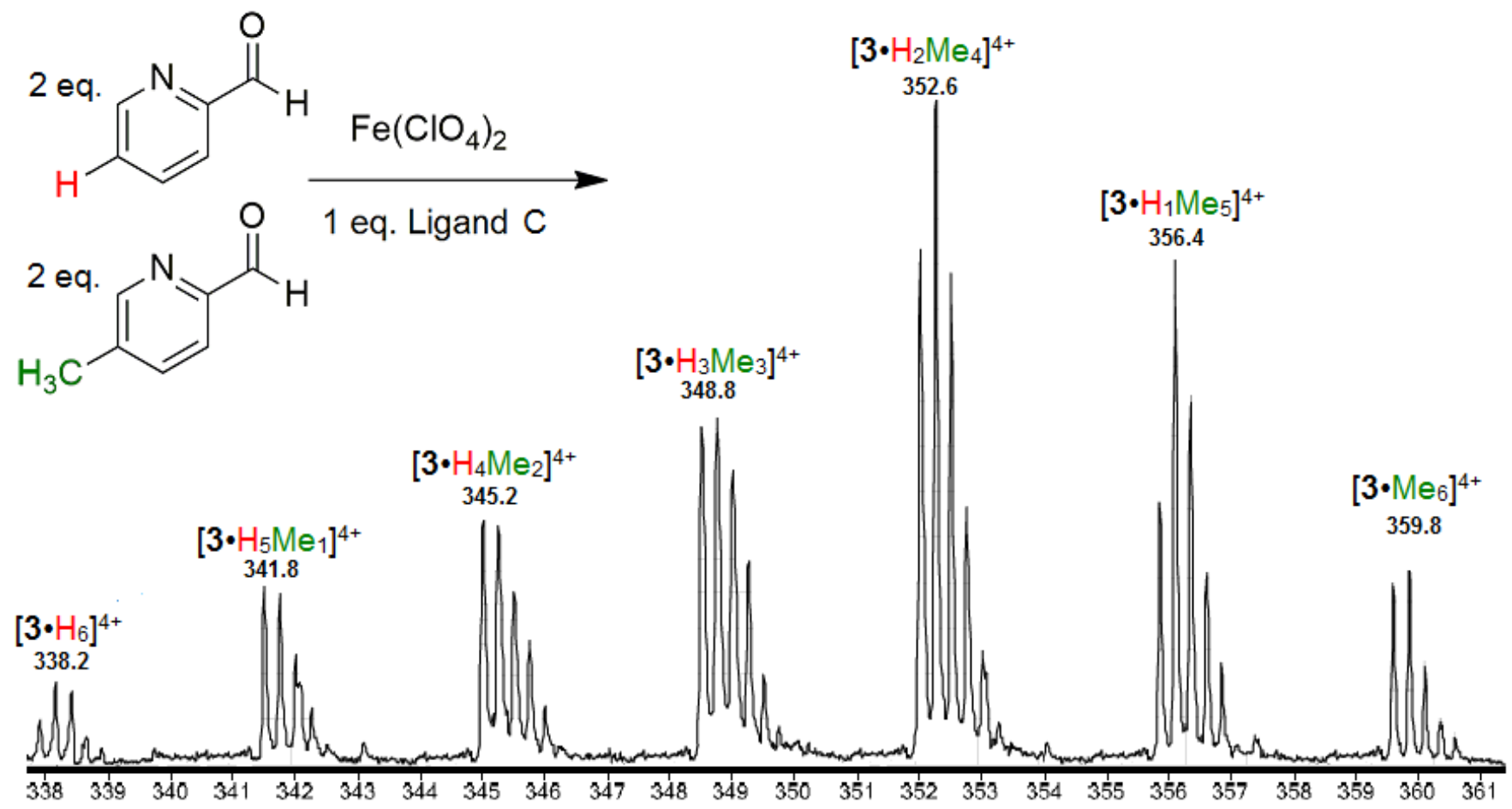

Figure S97. ESI-MS spectrum expansion of product distribution formed upon mixing ligand $\mathbf{C}$ with $\mathrm{Fe}\left(\mathrm{ClO}_{4}\right)_{2}$ and equimolar amounts of formylpyridine $\mathbf{4}$ and methyl-formylpyridine $\mathbf{6}$ (four equivalents total) in $\mathrm{CH}_{3} \mathrm{CN}$ with heating at $55^{\circ} \mathrm{C}$ for $12 \mathrm{~h}\left(\mathrm{CH}_{3} \mathrm{CN}\right)$. 

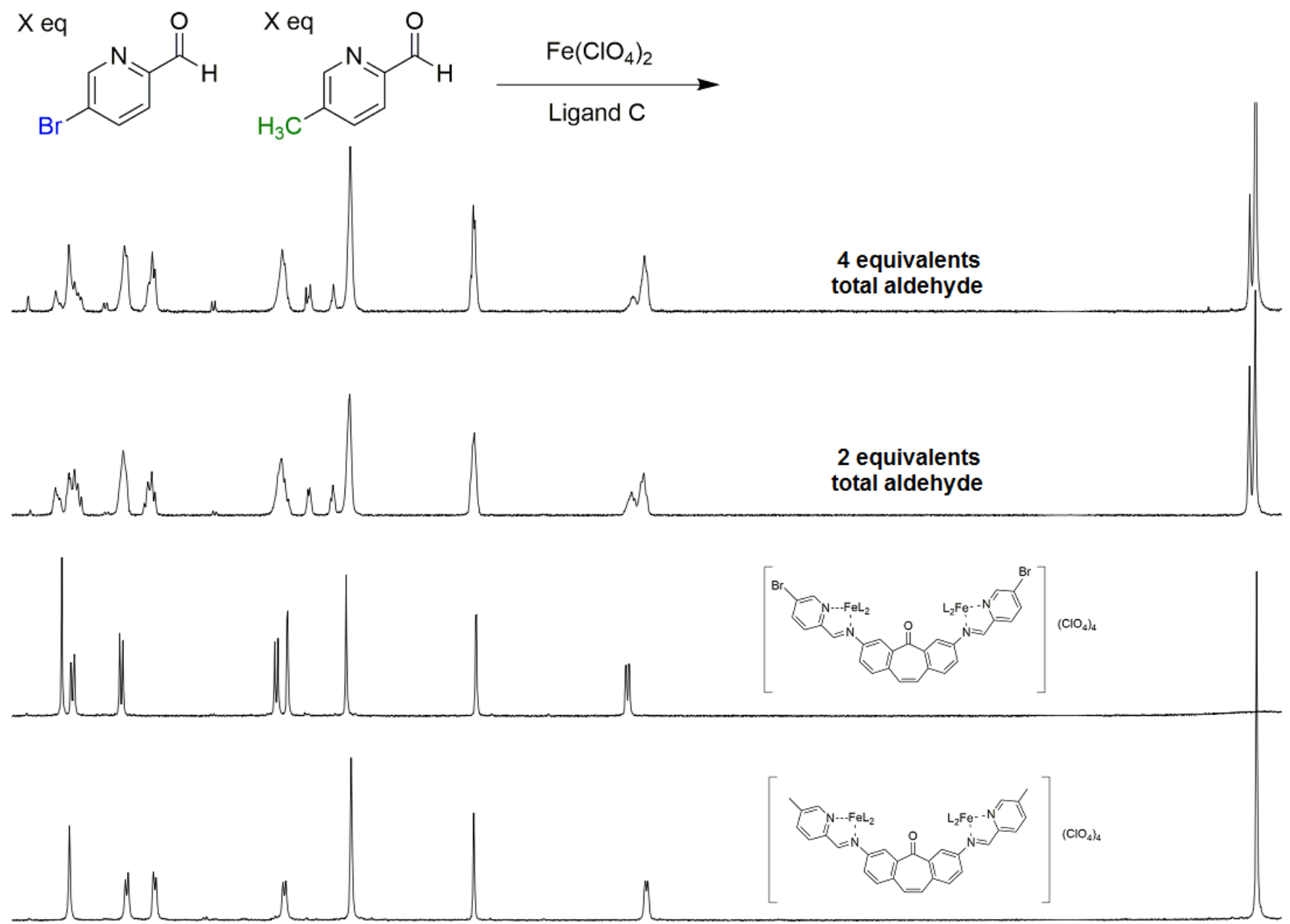

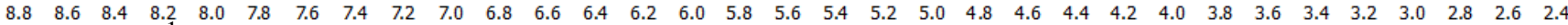
Figure S98. ${ }^{1} \mathrm{H}$ NMR spectrum of product distributions formed upon mixing ligand $\mathbf{C}$ with $\mathrm{Fe}\left(\mathrm{ClO}_{4}\right)_{2}$ and equimolar amounts of bromo-formylpyridine $\mathbf{5}$ and methyl-formylpyridine $\mathbf{6}$ (two equivalents and four equivalents total) in $\mathrm{CH}_{3} \mathrm{CN}$ with heating at $55^{\circ} \mathrm{C}$ for $12 \mathrm{~h}\left(\mathrm{CD}_{3} \mathrm{CN}, 500 \mathrm{MHz}\right.$, spectra taken at $\left.298 \mathrm{~K}\right)$. 


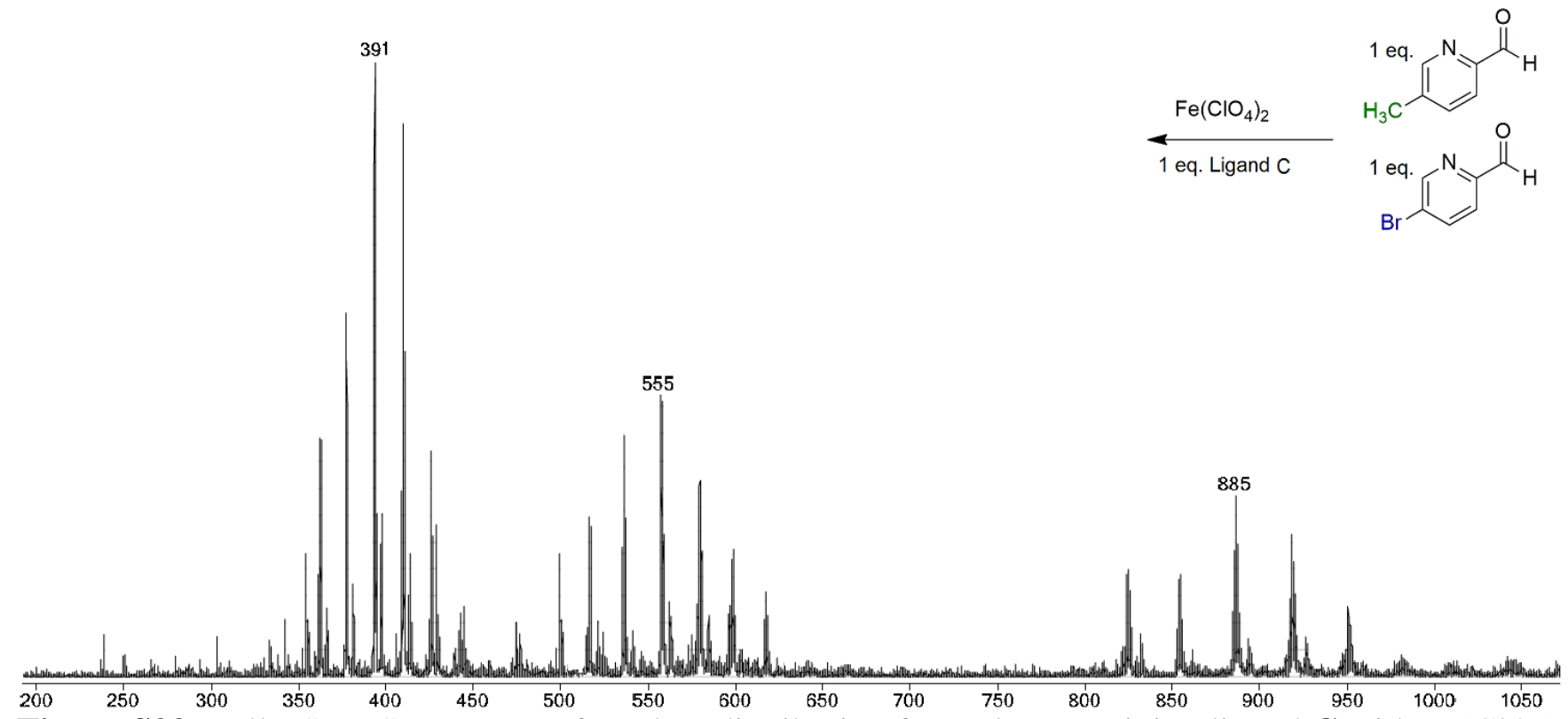

Figure S99. Full ESI-MS spectrum of product distribution formed upon mixing ligand $\mathbf{C}$ with $\mathrm{Fe}\left(\mathrm{ClO}_{4}\right)_{2}$ and equimolar amounts of bromo-formylpyridine $\mathbf{5}$ and methyl-formylpyridine $\mathbf{6}$ (two equivalents total) in $\mathrm{CH}_{3} \mathrm{CN}$ with heating at $55^{\circ} \mathrm{C}$ for $12 \mathrm{~h}\left(\mathrm{CH}_{3} \mathrm{CN}\right)$.

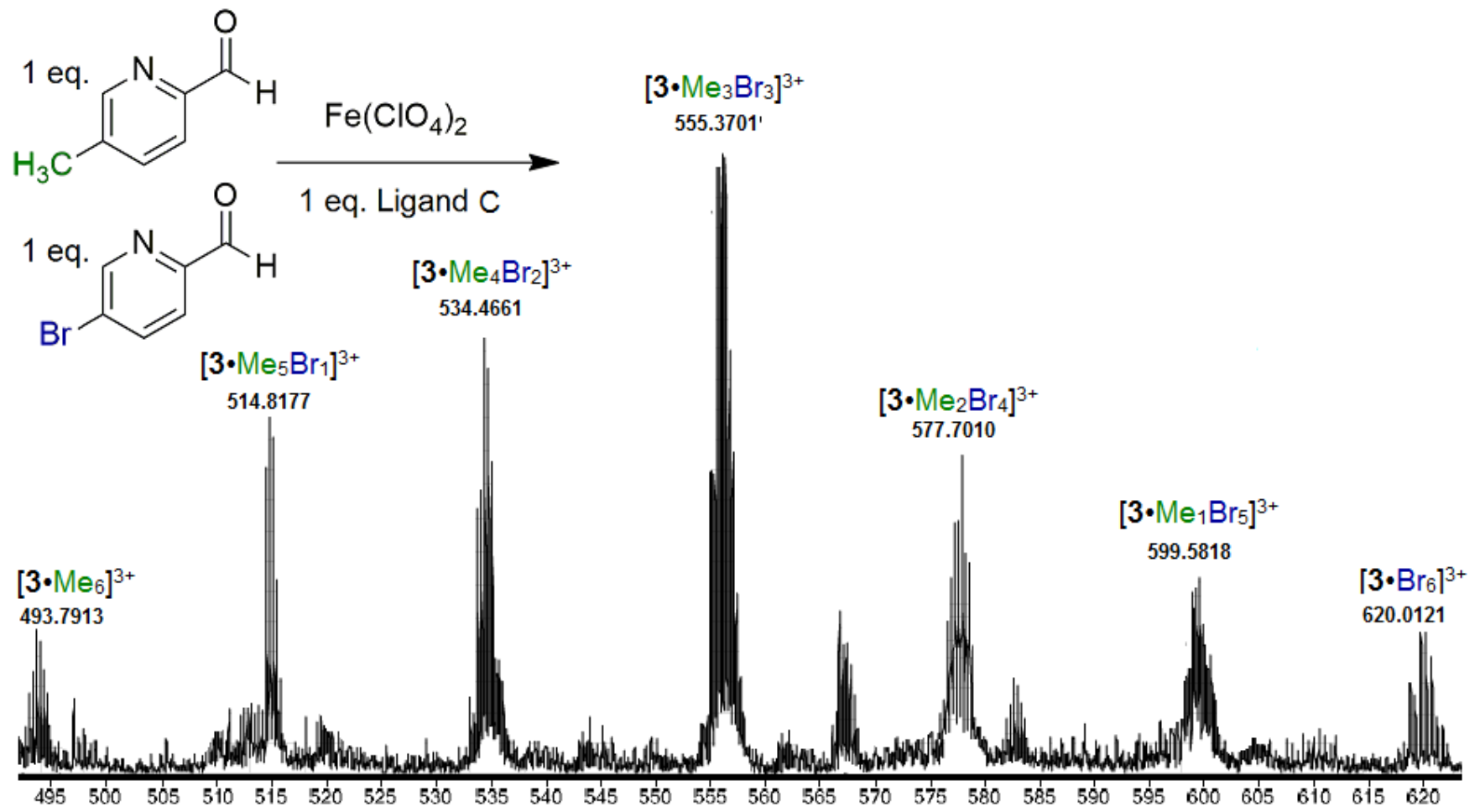

Figure S100. ESI-MS spectrum expansion of product distribution formed upon mixing ligand $\mathbf{C}$ with $\mathrm{Fe}\left(\mathrm{ClO}_{4}\right)_{2}$ and equimolar amounts of bromo-formylpyridine 5 and methyl-formylpyridine 6 (two equivalents total) in $\mathrm{CH}_{3} \mathrm{CN}$ with heating at $55^{\circ} \mathrm{C}$ for $12 \mathrm{~h}$. Peaks for the observed possible combinations of $\left[\left(3 \cdot \mathrm{Me}_{\mathrm{x}} \mathrm{Br}_{\mathrm{y}}\right) \cdot \mathrm{ClO}_{4}\right]^{3+}$ ions are shown $\left(\mathrm{CH}_{3} \mathrm{CN}\right)$. 

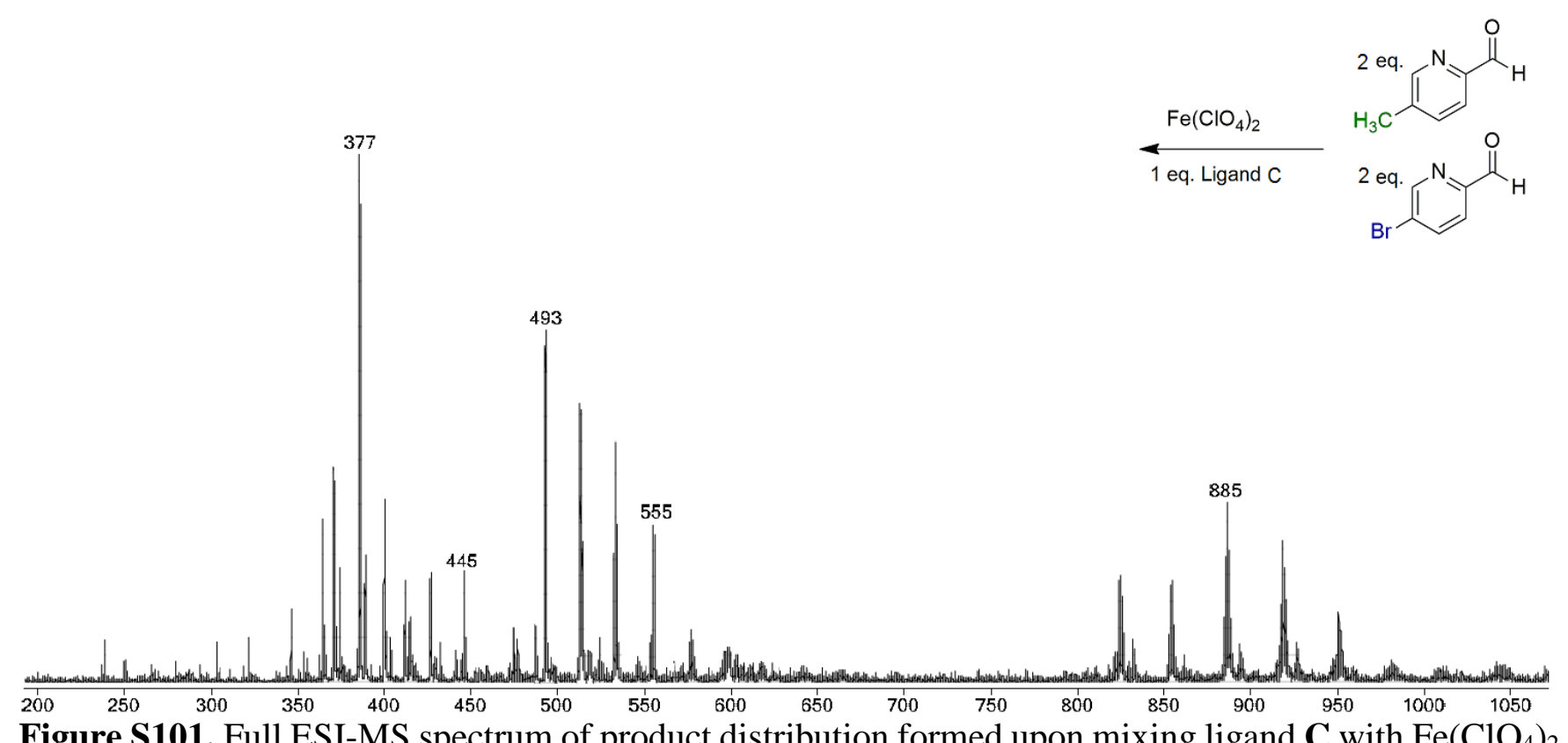

Figure S101. Full ESI-MS spectrum of product distribution formed upon mixing ligand $\mathbf{C}$ with $\mathrm{Fe}\left(\mathrm{ClO}_{4}\right)_{2}$ and equimolar amounts of bromo-formylpyridine $\mathbf{5}$ and methyl-formylpyridine $\mathbf{6}$ (four equivalents total) in $\mathrm{CH}_{3} \mathrm{CN}$ with heating at $55^{\circ} \mathrm{C}$ for $12 \mathrm{~h}\left(\mathrm{CH}_{3} \mathrm{CN}\right)$.

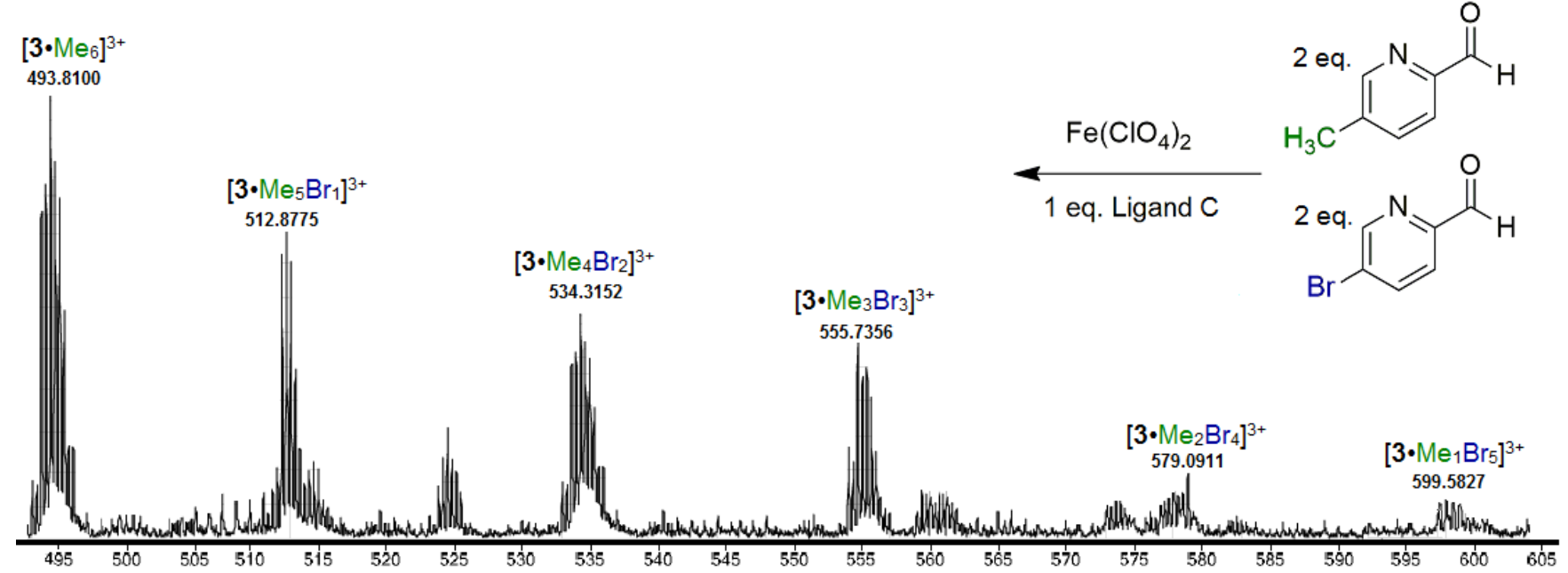

Figure S102. ESI-MS spectrum expansion of product distribution formed upon mixing ligand $\mathbf{C}$ with $\mathrm{Fe}\left(\mathrm{ClO}_{4}\right)_{2}$ and equimolar amounts of bromo-formylpyridine 5 and methyl-formylpyridine 6 (four equivalents total) in $\mathrm{CH}_{3} \mathrm{CN}$ with heating at $55^{\circ} \mathrm{C}$ for $12 \mathrm{~h}$. Peaks for the observed possible combinations of $\left[\left(3 \cdot \mathrm{Me}_{\mathrm{x}} \mathrm{Br}_{\mathrm{y}}\right) \cdot \mathrm{ClO}_{4}\right]^{3+}$ ions are shown $\left(\mathrm{CH}_{3} \mathrm{CN}\right)$. 


\section{Aldehyde Displacement and Kinetics}

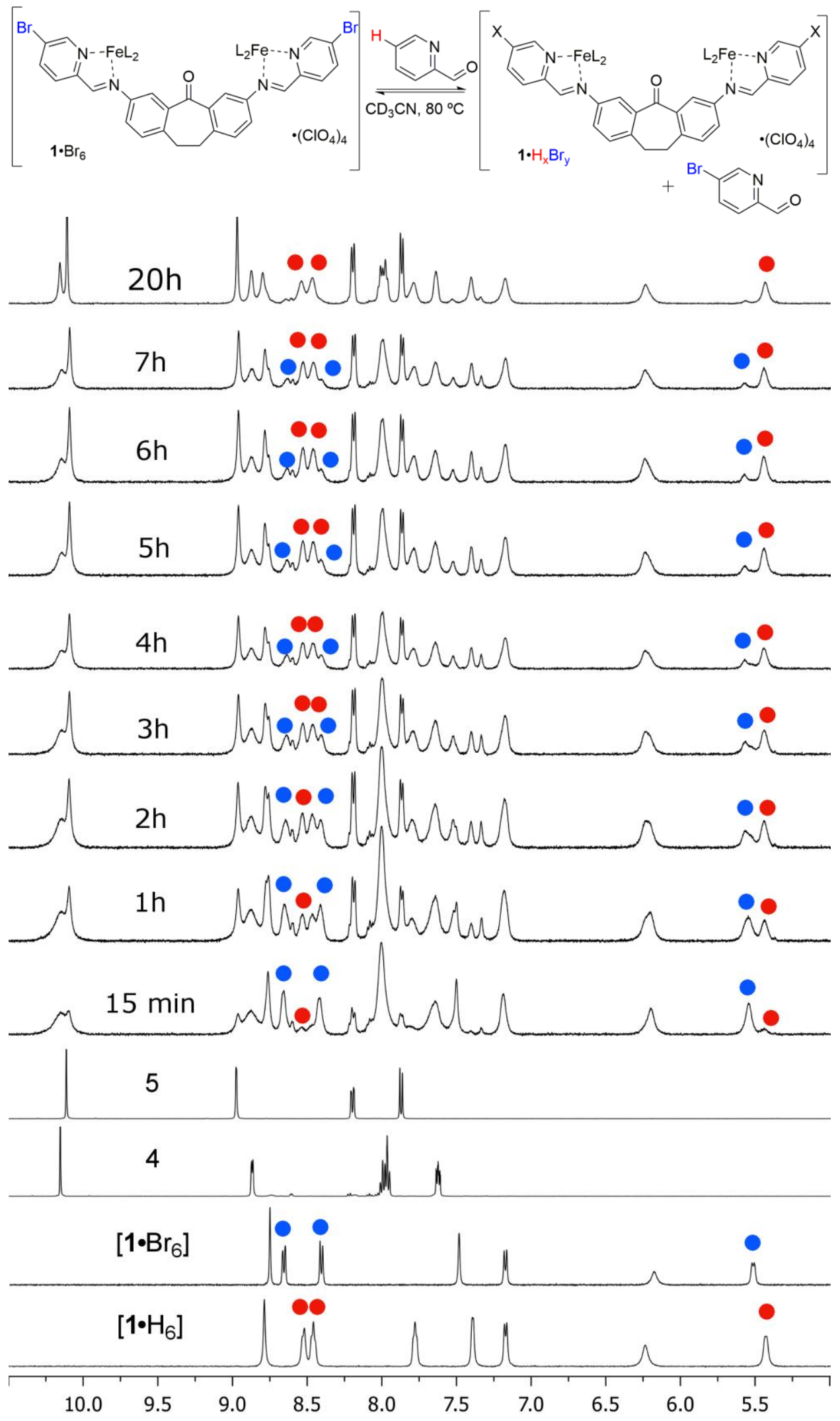


Figure S103. ${ }^{1} \mathrm{H}$ NMR spectra of displacement of bromo-formylpyridine $\mathbf{5}$ in cage $\mathbf{1} \cdot \mathrm{Br}_{6}$ with formylpyridine 4 over $20 \mathrm{~h}$ at $80{ }^{\circ} \mathrm{C}\left(\mathrm{CD}_{3} \mathrm{CN}, 500 \mathrm{MHz}, 298 \mathrm{~K}\right)$.

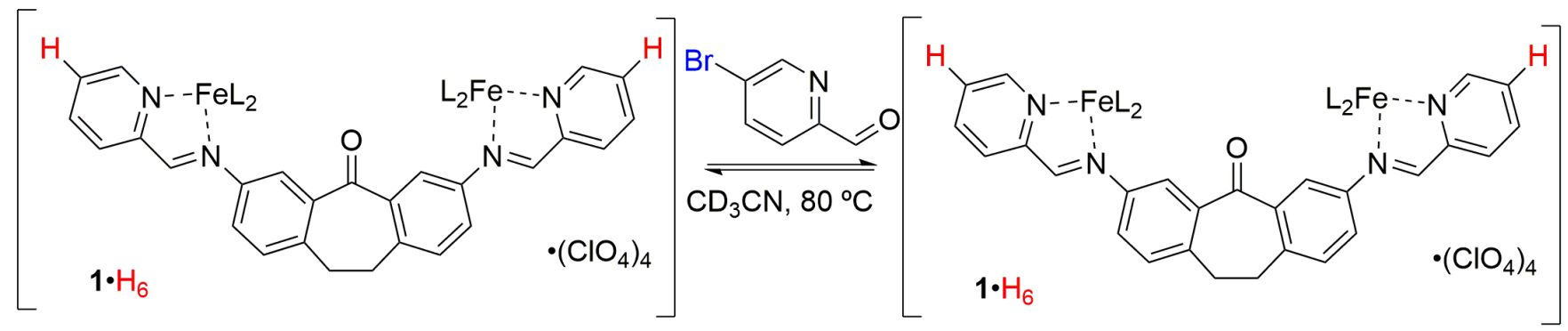

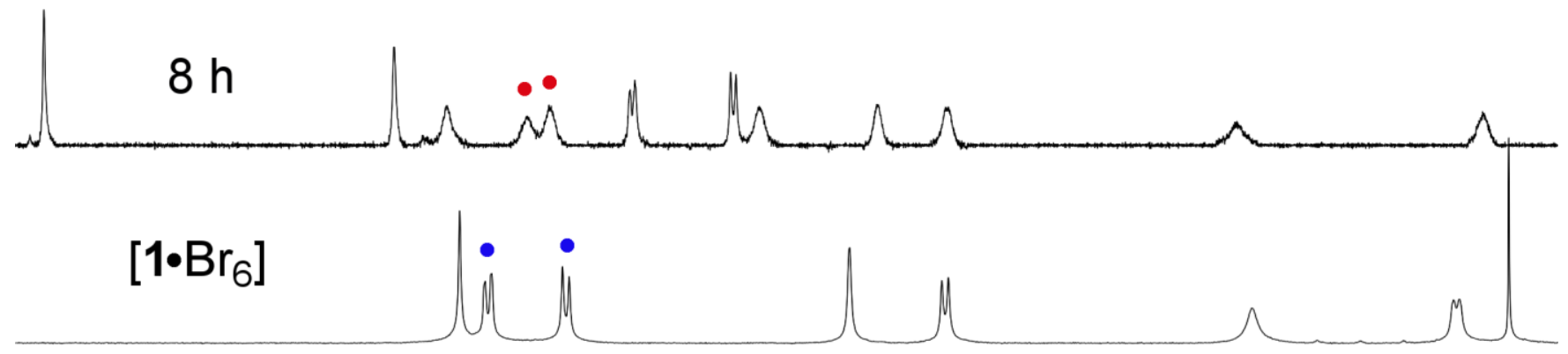

$\left[1 \bullet \mathrm{H}_{6}\right]$

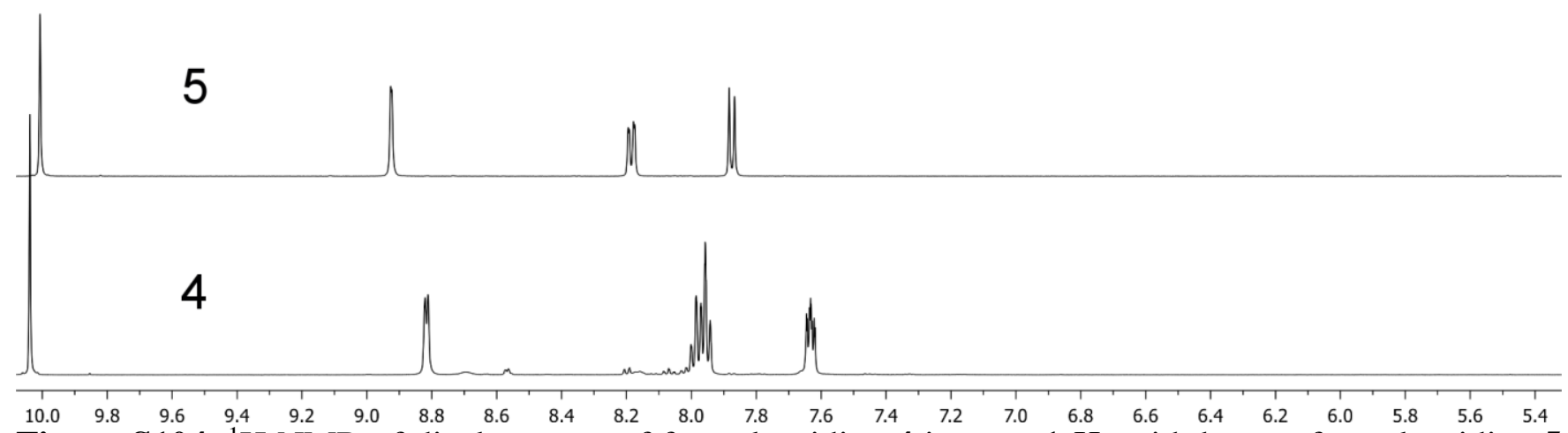

Figure S104. ${ }^{1} \mathrm{H}$ NMR of displacement of formylpyridine 4 in cage $\mathbf{1} \cdot \mathrm{H}_{6}$ with bromo-formylpyridine 5 over $8 \mathrm{~h}$ at $80^{\circ} \mathrm{C}$. No substitution of the unsubstituted 2 -formyl pyridine was observed $\left(\mathrm{CD}_{3} \mathrm{CN}, 500 \mathrm{MHz}\right.$, $298 \mathrm{~K})$. 

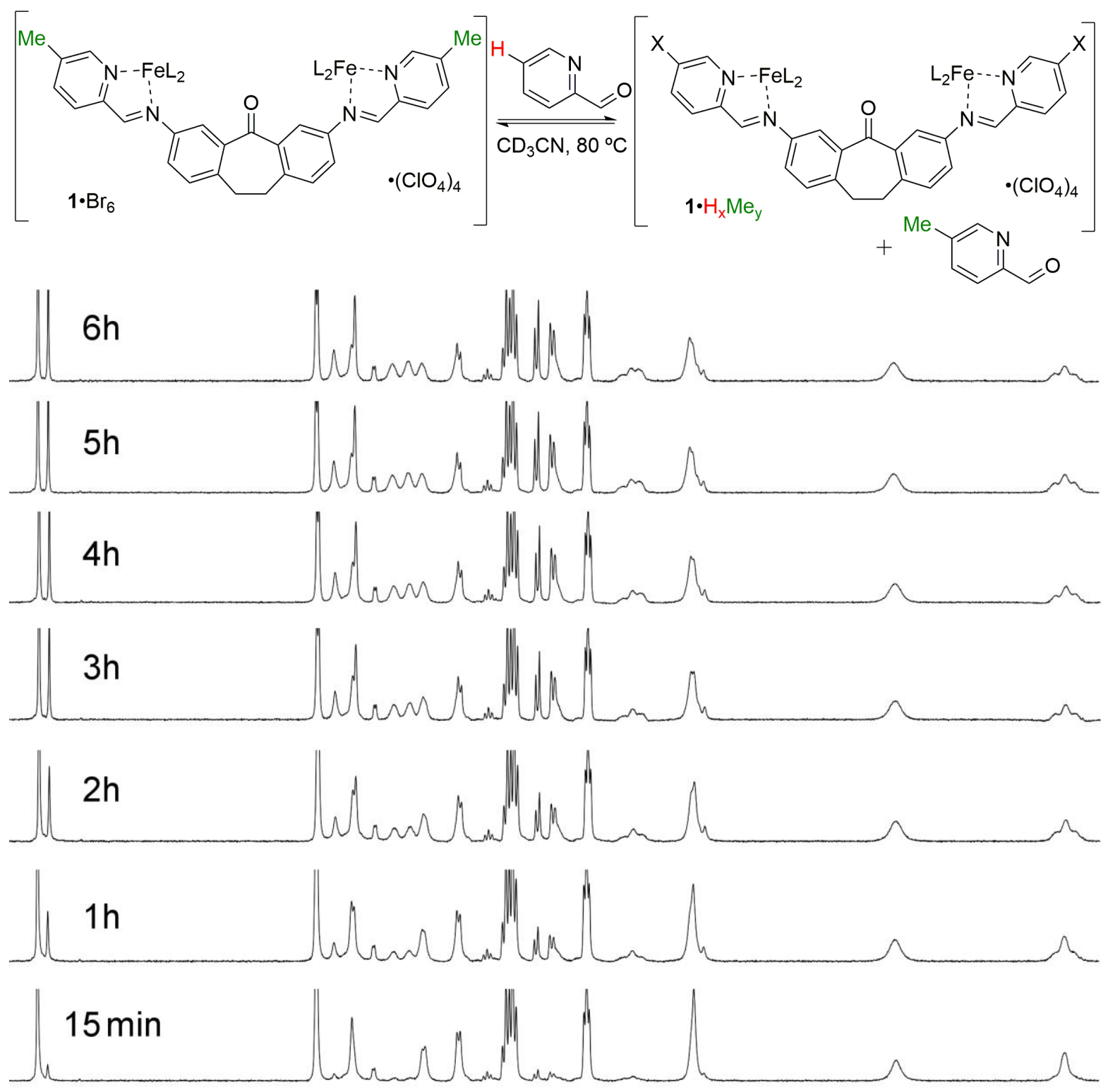

$\left[1 \bullet \mathrm{H}_{6}\right]$

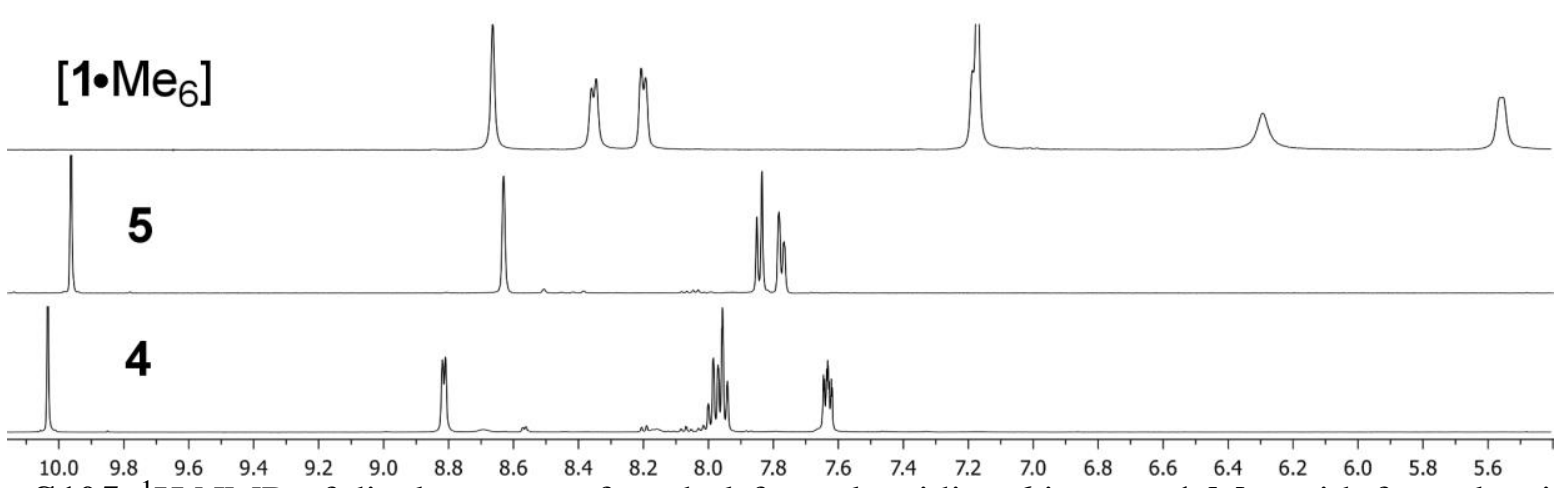

Figure S105. ${ }^{1} \mathrm{H}$ NMR of displacement of methyl-formylpyridine 6 in cage $\mathbf{1} \cdot \mathrm{Me}_{6}$ with formylpyridine 4 over $6 \mathrm{~h}$ at $80{ }^{\circ} \mathrm{C}$. Equilibration to mixed heterocomplexes observed. (CD $\left.3 \mathrm{CN}, 500 \mathrm{MHz}, 298 \mathrm{~K}\right)$. 

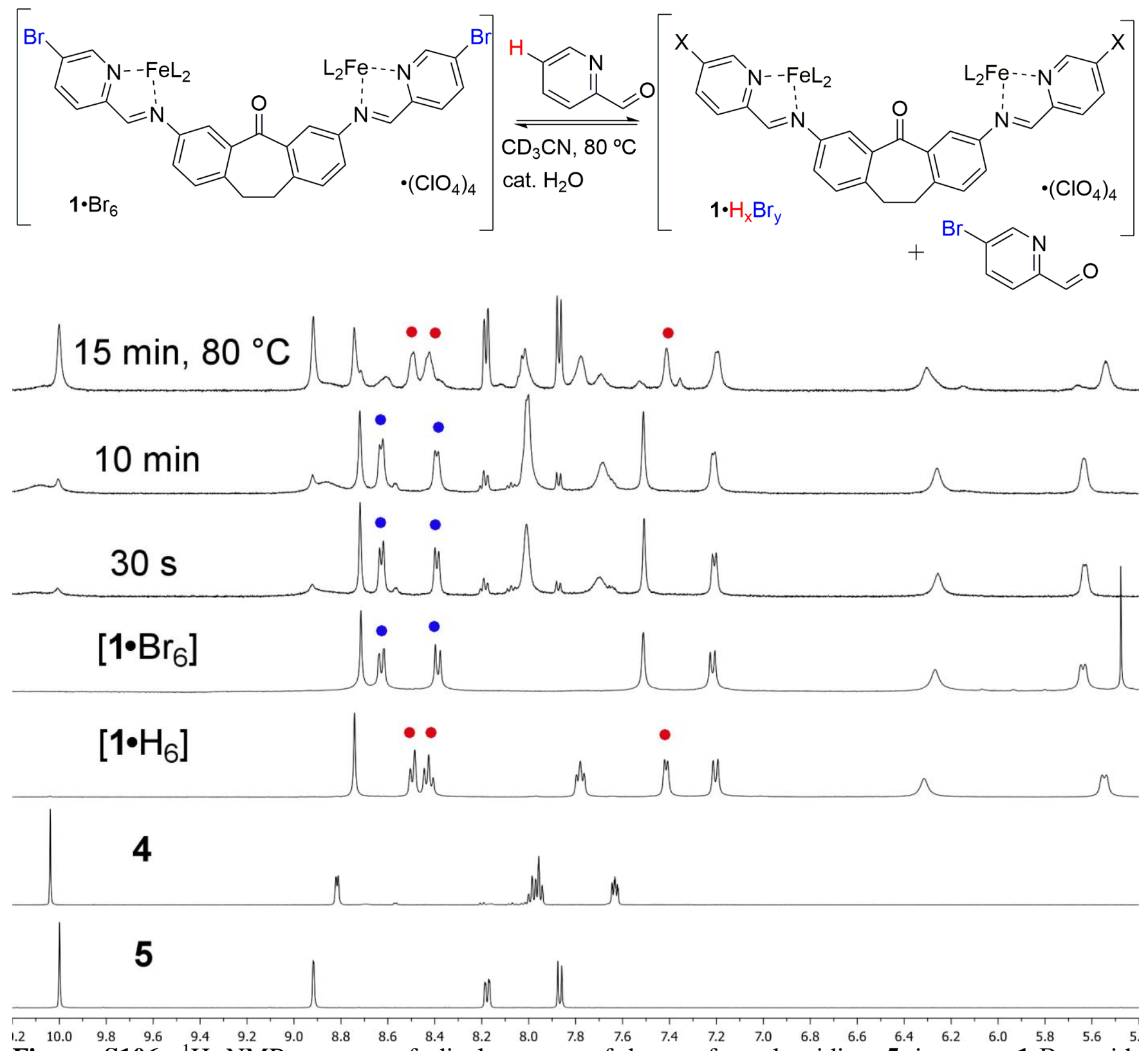

Figure S106. ${ }^{1} \mathrm{H}$ NMR spectra of displacement of bromo-formylpyridine $\mathbf{5}$ in cage $\mathbf{1 \cdot B r} 6$ with formylpyridine 4 and catalytic $\mathrm{H}_{2} \mathrm{O}$ at $25^{\circ} \mathrm{C}$ for $10 \mathrm{~min}$ followed by $80^{\circ} \mathrm{C}$ for $15 \mathrm{~min}$. $\left(\mathrm{CD}_{3} \mathrm{CN}, 500 \mathrm{MHz}\right.$, 298 K). 

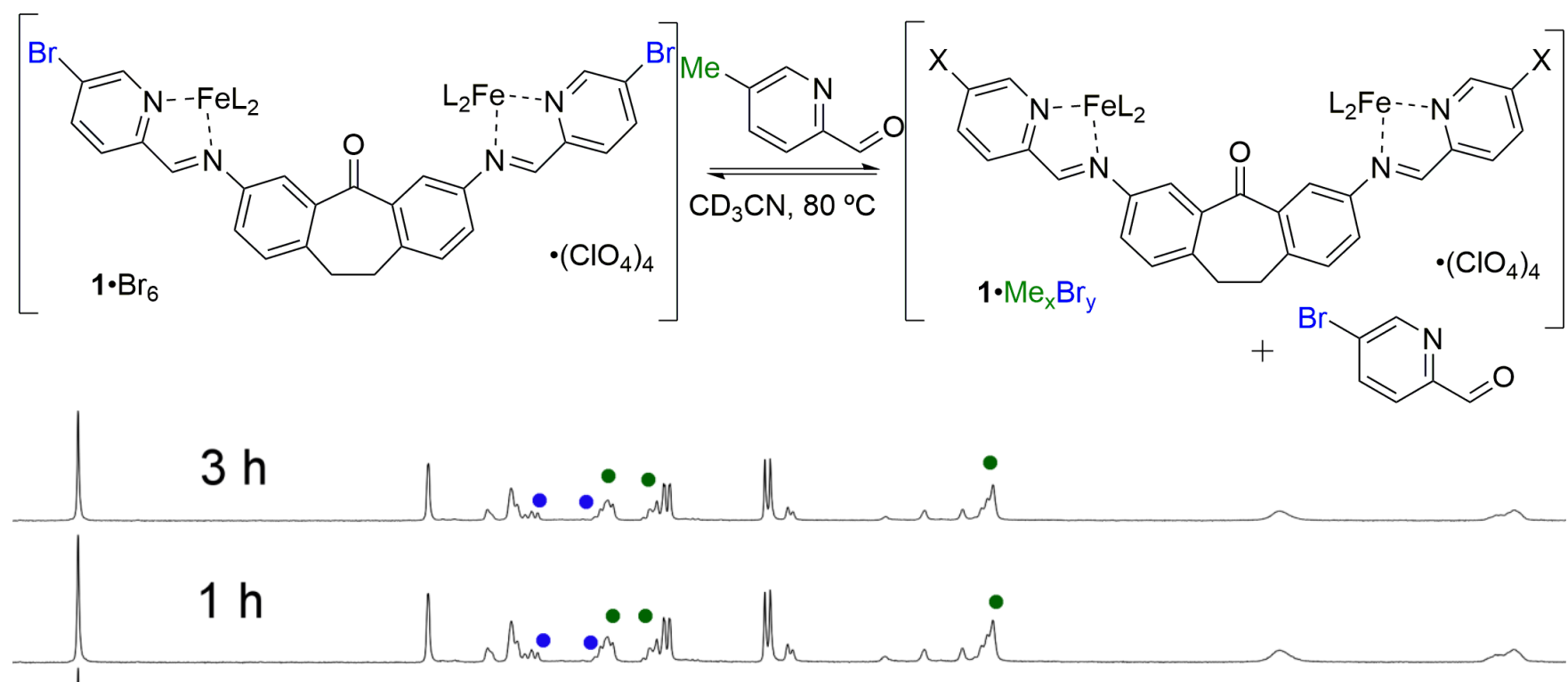

$15 \min$

$\left[1 \bullet \mathrm{Me}_{6}\right]$

$\left[1 \cdot \mathrm{Br}_{6}\right]$

5

6
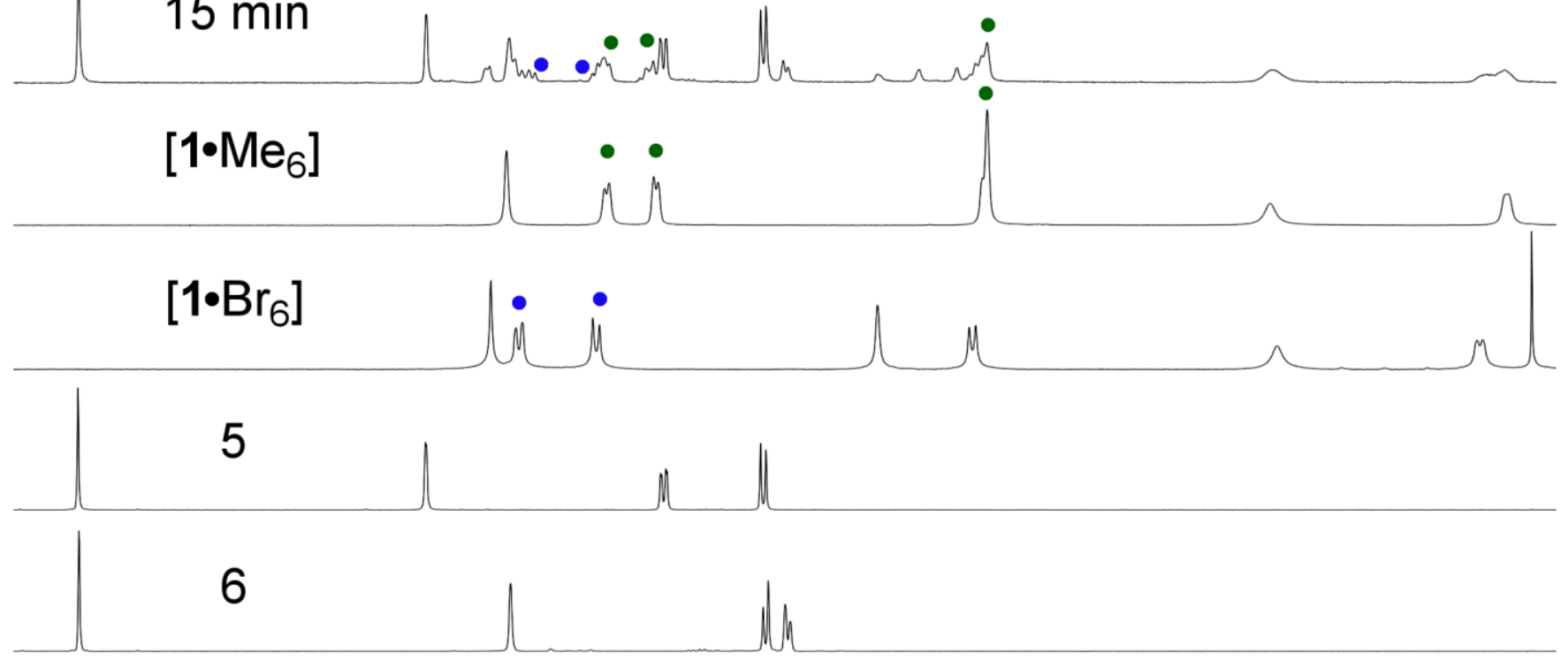

$\begin{array}{lllllllllllllllllllllllll}1.2 & 10.0 & 9.8 & 9.6 & 9.4 & 9.2 & 9.0 & 8.8 & 8.6 & 8.4 & 8.2 & 8.0 & 7.8 & 7.6 & 7.4 & 7.2 & 7.0 & 6.8 & 6.6 & 6.4 & 6.2 & 6.0 & 5.8 & 5.6 & 5\end{array}$ Figure S107. ${ }^{1} \mathrm{H}$ NMR spectra of displacement of bromo-formylpyridine $\mathbf{5}$ in cage $\mathbf{1} \cdot \mathrm{Br}_{6}$ with methylformylpyridine 6 over $3 \mathrm{~h}$ at $80{ }^{\circ} \mathrm{C}\left(\mathrm{CD}_{3} \mathrm{CN}, 500 \mathrm{MHz}, 298 \mathrm{~K}\right)$. 


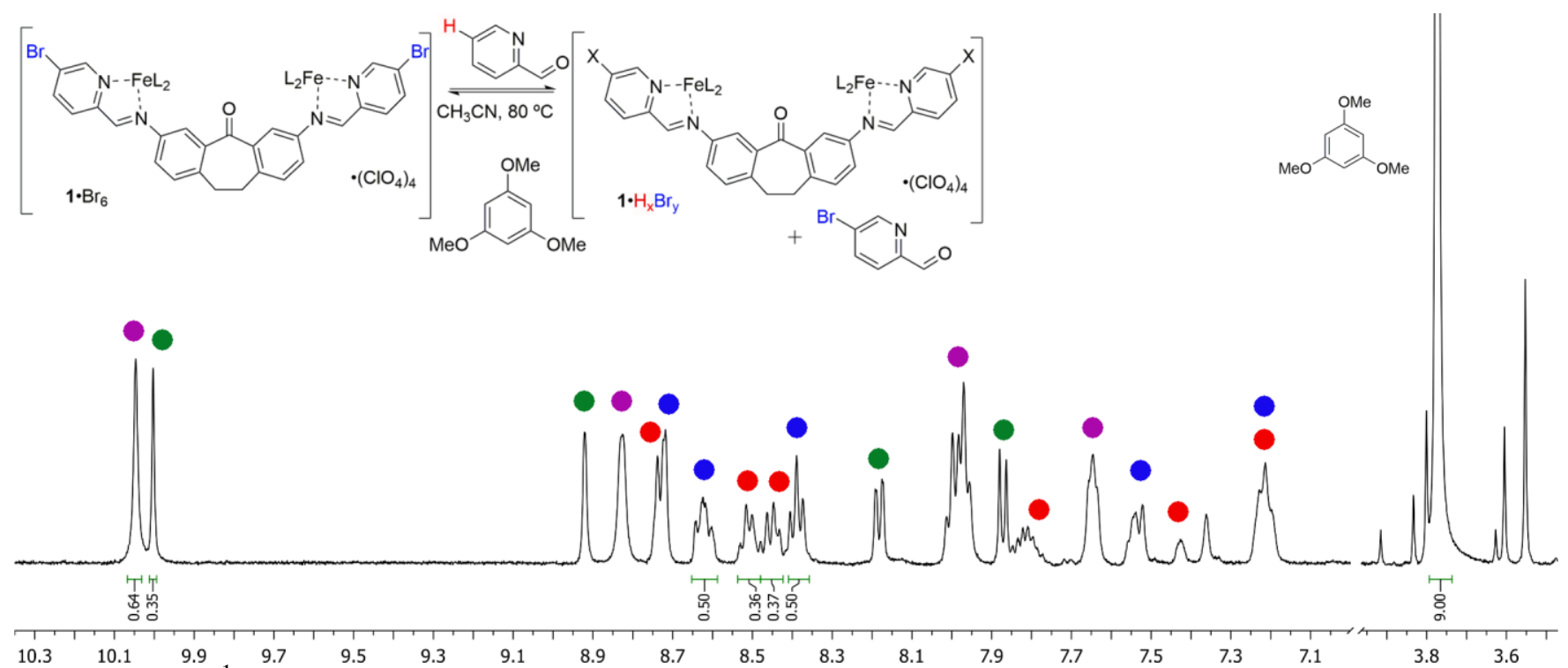

Figure S108. ${ }^{1} \mathrm{H}$ NMR spectra of displacement of $\mathrm{Br}-\mathrm{PyCHO} 5$ (green) in cage $\mathbf{1} \cdot \mathrm{Br}_{6}$ (blue) with $\mathrm{PyCHO}$ 4 (purple) over $6 \mathrm{~h}$ at $80{ }^{\circ} \mathrm{C}$ to form a mixture of $\mathbf{1} \cdot \mathrm{Br}_{6}$ and $\mathbf{1} \cdot \mathrm{H}_{6}$ (red). 1,3,5-Trimethoxybenzene included as an internal standard. $\left(\mathrm{CD}_{3} \mathrm{CN}, 500 \mathrm{MHz}, 298 \mathrm{~K}\right)$.

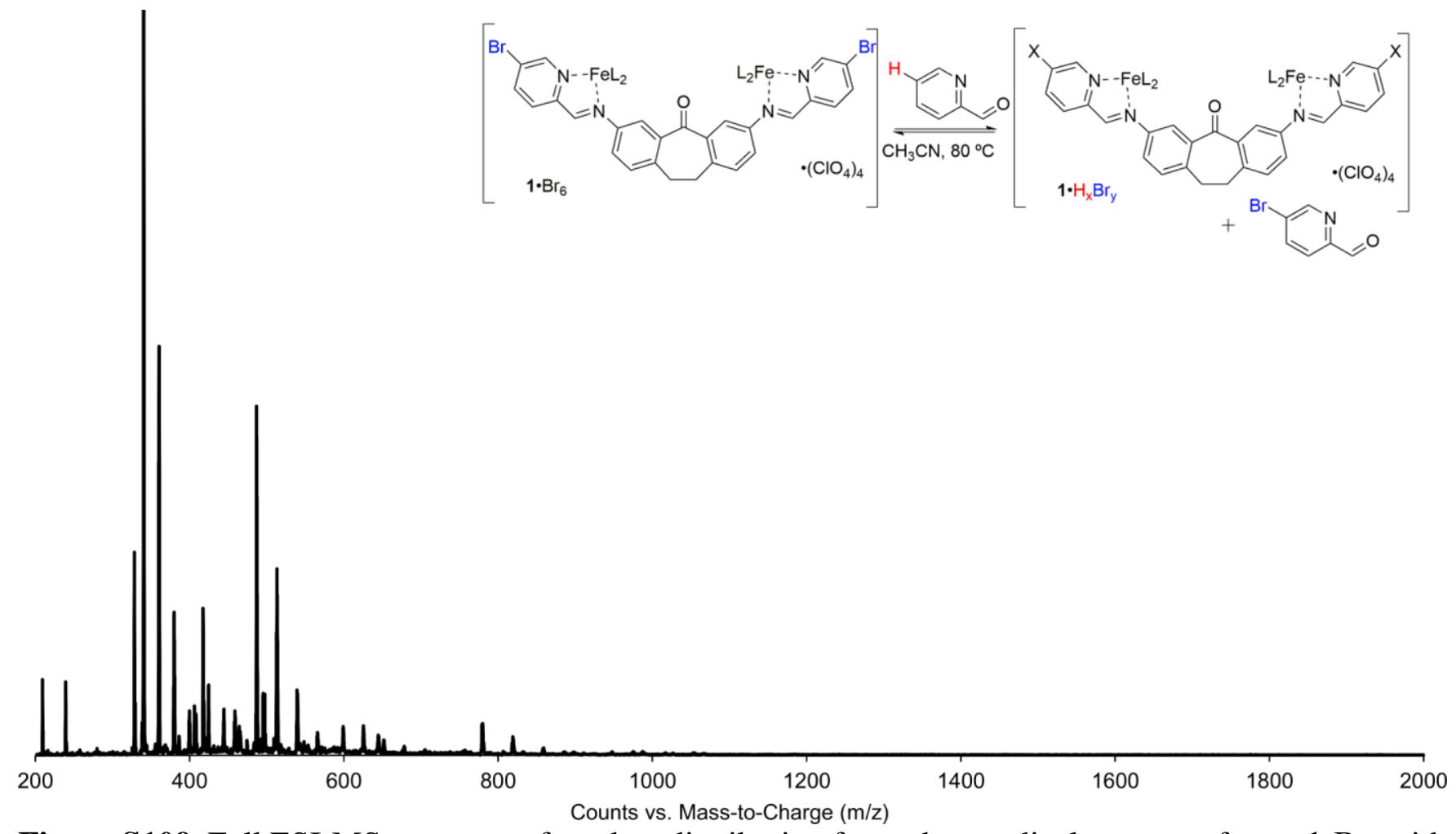

Figure S109. Full ESI-MS spectrum of product distribution formed upon displacement of cage $1 \cdot \mathrm{Br}_{6}$ with PyCHO 4 (two equivalents) in $\mathrm{CH}_{3} \mathrm{CN}$ with heating at $80{ }^{\circ} \mathrm{C}$ for $6 \mathrm{~h}\left(\mathrm{CH}_{3} \mathrm{CN}\right)$. 


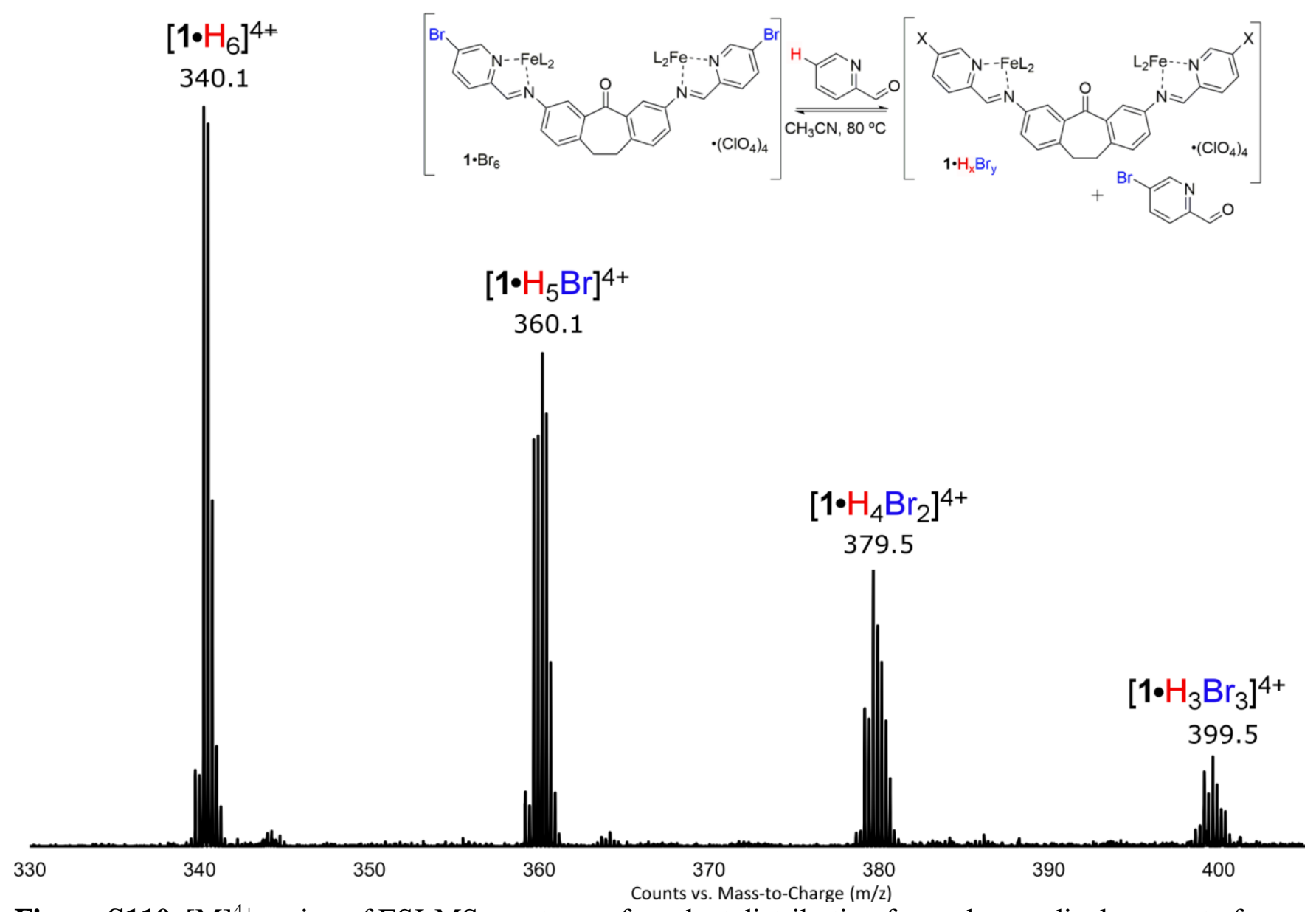

Figure S110. $[\mathrm{M}]^{4+}$ region of ESI-MS spectrum of product distribution formed upon displacement of cage 1. $\mathrm{Br}_{6}$ with PyCHO 4 (two equivalents) in $\mathrm{CH}_{3} \mathrm{CN}$ with heating at $80{ }^{\circ} \mathrm{C}$ for $6 \mathrm{~h}\left(\mathrm{CH}_{3} \mathrm{CN}\right)$. 

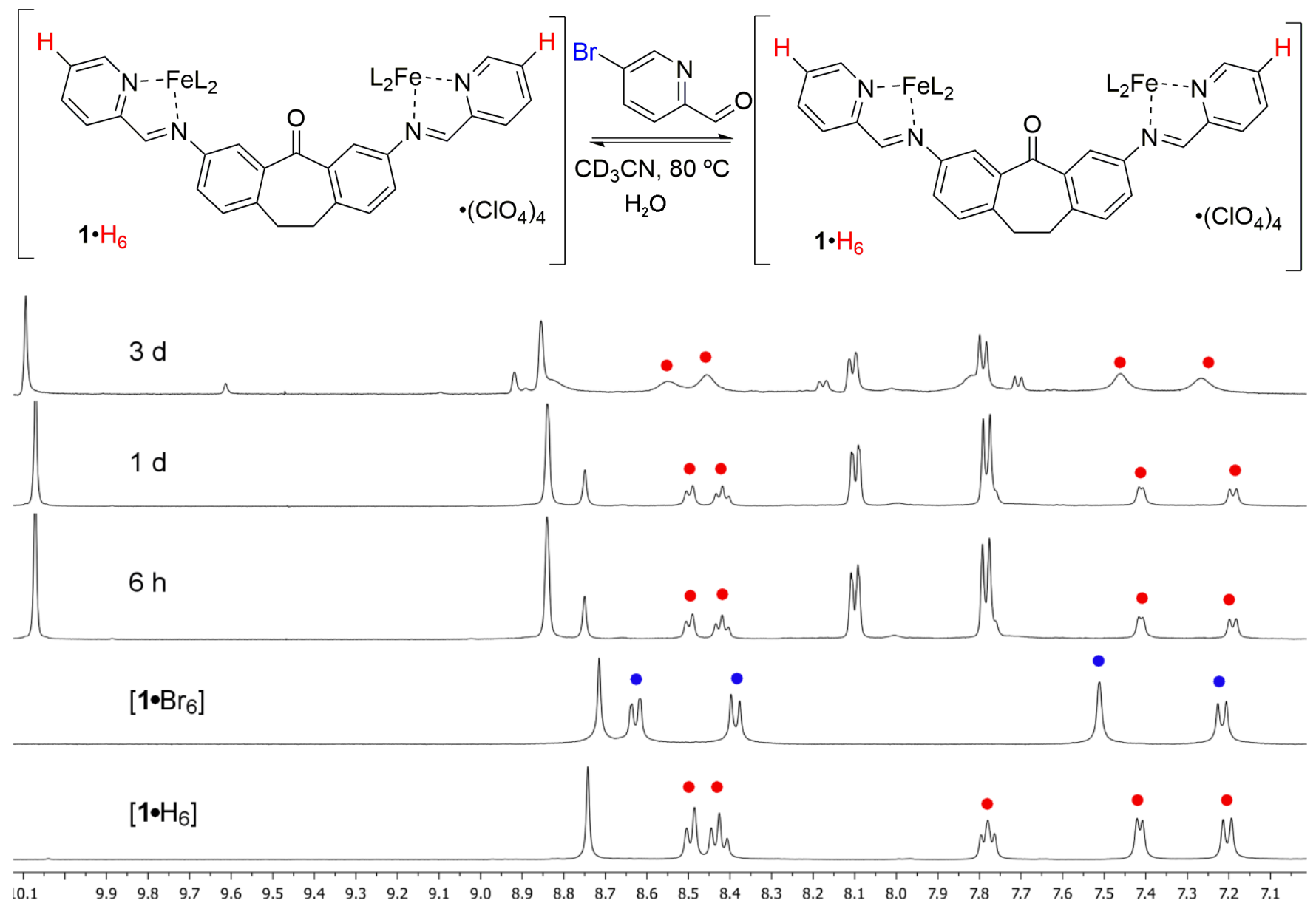

Figure S111. ${ }^{1} \mathrm{H}$ NMR spectra of displacement of addition of Br-PyCHO 5 (2 equivalents) to cage $\mathbf{1} \cdot \mathrm{H}_{6}$ (red) over 3 days at $80{ }^{\circ} \mathrm{C}$ to resulting in only presence of cage $\mathbf{1} \cdot \mathrm{H}_{6}$ and decomposition products. $\mathrm{H}_{2} \mathrm{O}(20$ $\mu \mathrm{L})$ was added to encourage displacement $\left(\mathrm{CD}_{3} \mathrm{CN}, 500 \mathrm{MHz}, 298 \mathrm{~K}\right)$. 


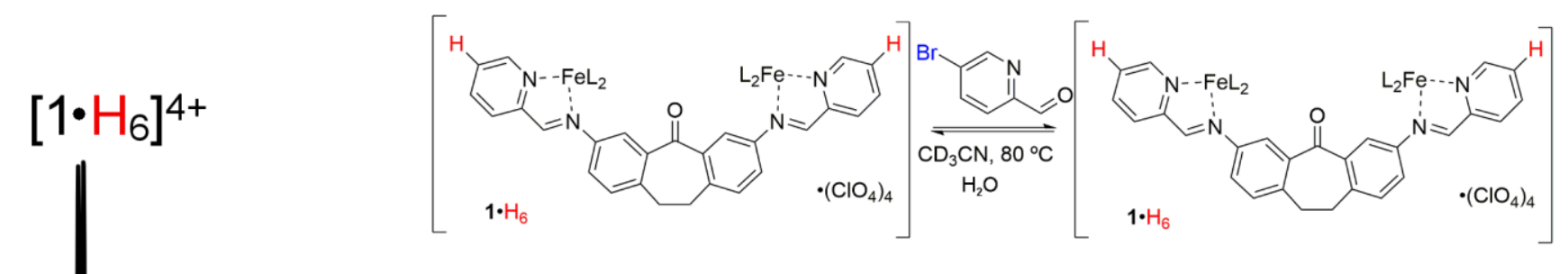

\section{$3 d$}

$\left[1 \cdot \mathrm{H}_{6}\right]^{4+}$

$1 \mathrm{~d}$

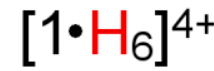

14

340

360

370

380

390

400

Counts vs. Mass-to-Charge ( $\mathrm{m} / \mathrm{z})$

Figure S112. $[\mathrm{M}]^{4+}$ region of ESI-MS spectrum of product distribution formed upon addition of BrPyCHO (two equivalents) 5 to cage $\mathbf{1} \cdot \mathrm{H}_{6}$ in $\mathrm{CH}_{3} \mathrm{CN}$ with heating at $80{ }^{\circ} \mathrm{C}$ for $3 \mathrm{~d} . \mathrm{H}_{2} \mathrm{O}(20 \mu \mathrm{L})$ was added to encourage displacement $\left(\mathrm{CH}_{3} \mathrm{CN}\right)$. 

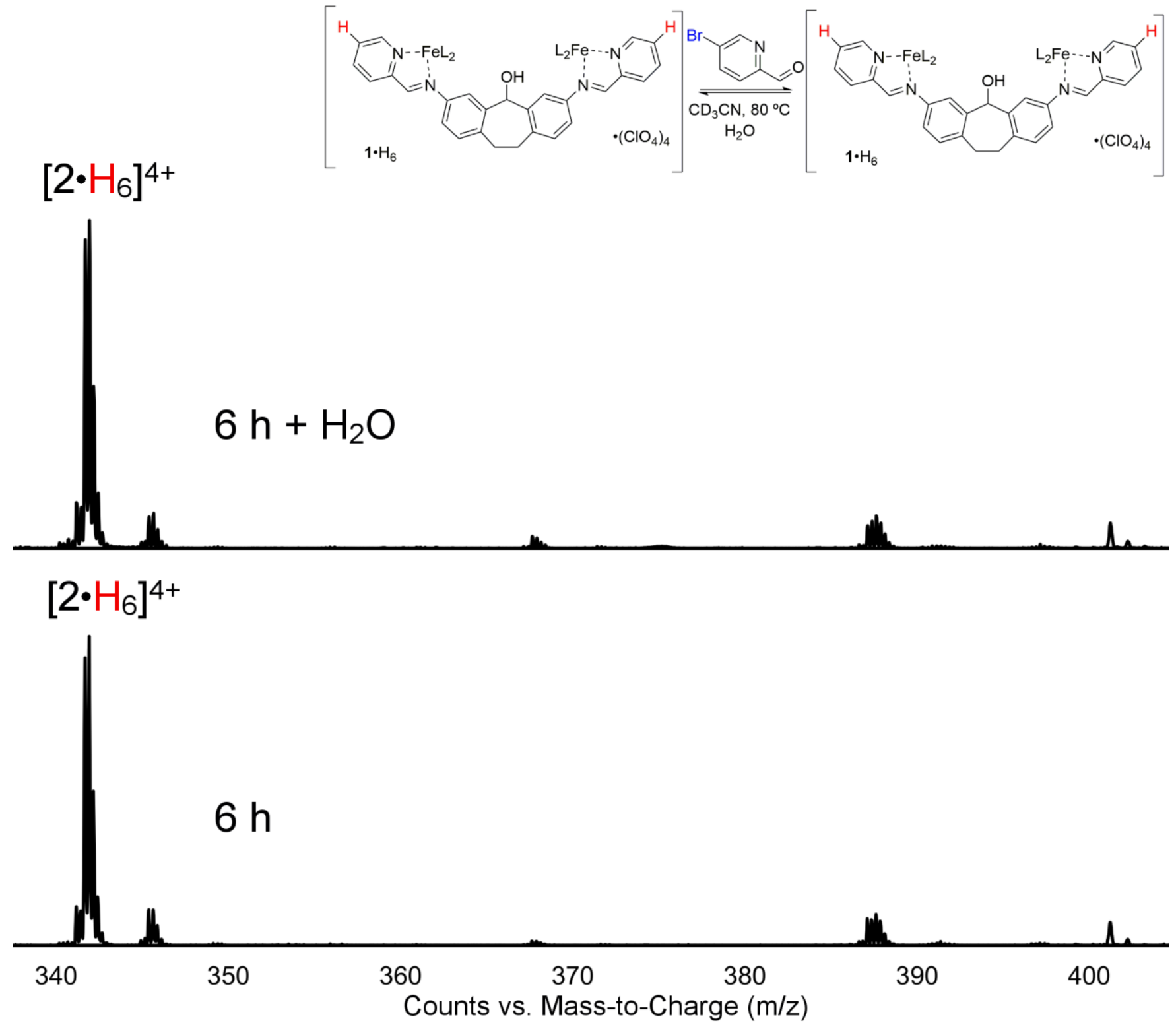

Figure S113. $[\mathrm{M}]^{4+}$ region of ESI-MS spectrum of product distribution formed upon addition of $\mathrm{Br}$ PyCHO (two equivalents) 5 to cage $2 \cdot \mathrm{H}_{6}$ in $\mathrm{CH}_{3} \mathrm{CN}$ with heating at $80{ }^{\circ} \mathrm{C}$ for $6 \mathrm{~h}$. Top: $\mathrm{H}_{2} \mathrm{O}(20 \mu \mathrm{L})$ was added to encourage displacement $\left(\mathrm{CH}_{3} \mathrm{CN}\right)$. 